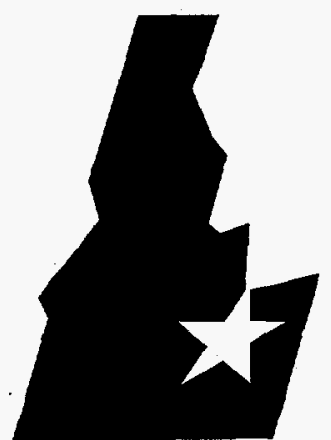

Idaho National

Engineering Laboratory
July 1997

\section{Interim Qualitative Risk Assessment for an LNG Refueling Station and Review of Relevant Safety Issues}

\section{Nathan Siu}

Stephen Herring

Lee Cadwallader

Wendy Reece

James Byers

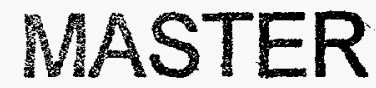

L OCKHEED MARTIN

DESTRIBUTION OF THIS 


\title{
Interim Qualitative Risk Assessment for an LNG Refueling Station and Review of Relevant Safety Issues
}

\author{
Nathan Siu \\ Stephen Herring \\ Lee Cadwallader \\ Wendy Reece \\ James Byers
}

Published July 1997

Idaho National Engineering and Environmental Laboratory Alternate Fuels Program Lockheed Martin Idaho Technologies Company Idaho Falls, Idaho 83415 


\section{DISCLAMMER}

Portions of this doevoment may be illegible in electronic image products. Images are produced from the best available original document 


\section{ABSTRACT}

This report is a qualitative assessment of the public and worker risk involved with the operation of a liquefied natural (LNG) vehicle refueling facility. This study includes facility maintenance and operations, tanker truck deliveries and end-use vehicle fueling; it does not treat the risks of LNG vehicles on roadways. Accident initiating events are identified by using a Master Logic Diagram, a Failure Modes and Effects Analysis and historical operating experiences. The event trees were drawn to depict possible sequences of mitigating events following the initiating events. The phenomenology of LNG and other vehicle fuels is discussed to characterize the hazard posed by LNG usage. Based on the risk modeling and analysis, recommendations are given to improve the safety of LNG refueling stations in the areas of procedures and training, station design, and the dissemination of "best practice" information throughout the LNG community. 


\section{SUMMARY}

This report is a qualitative assessment of the public and worker risk involved with the operation of a liquefied natural (LNG) vehicle refueling facility. A cryogenic fuel for vehicles is very different from the petroleum fuels presently in use. LNG rapidly evolves gas, it can cause cryogenic burns from skin contact and exposure can cause brittleness in many engineering materials. This study includes facility maintenance and operations, tanker truck deliveries and end-use vehicle fueling; it does not treat the risks of LNG vehicles on roadways. The qualitative risks have been outlined in Tables 1-2 and 1-3.

The report gives a description of refueling facilities visited and identifies the technologies involved for system familiarization. Then accident initiating events are identified by using a Master Logic Diagram, a Failure Modes and Effects Analysis and historical operating experiences. The event trees were drawn to depict possible sequences of mitigating events following the initiating events.

The phenomenology of LNG and other vehicle fuels is discussed to characterize the hazard posed by LNG usage. Physical parameters, methane flammability and LNG issues such as weathering, rollover and geysering are discussed. Distinctions in phenomena between LNG peak-shaving plants and refueling stations are explained and evaluated.

Based on the risk modeling and analysis, recommendations are given in the conclusions section. These recommendations to improve the safety of LNG refueling stations are in the areas of procedures and training, station design (especially leak pathway analysis) and fostering the dissemination of "best practice" information throughout the LNG community. 


\section{FOREWORD}

This risk assessment cites several past incidents in the use and handling of liquefied natural gas. We have relied on literature searches, the US Department of Transportation database, and the memory of experts in the LNG field to gather information on these incidents. If any readers of this report know of incidents not cited and can provide information on such incidents, they are invited to contact Dr. Steve Herring, 208-526-9497, sth@inel.gov or Lee Cadwallader, 208-526-1232, lcc@inel.gov.

Furthermore, if any readers can suggest other members of the LNG community to whom this report should be sent, please notify us at an address listed above. 


\section{ACKNOWLEDGMENTS}

The support of Robert Helton (U.S. Department of Energy), Richard Rice and Bruce Wilding (Lockheed-Martin Idaho Technologies Co.) are gratefully acknowledged. This report was prepared under the U.S. Department of Energy (DOE) Idaho Field Office Contract DE-AC07-94ID13223. The opinions, findings, conclusions and recommendations expressed herein are those of the authors and do not necessarily reflect the views of the DOE. 


\section{CONTENTS}

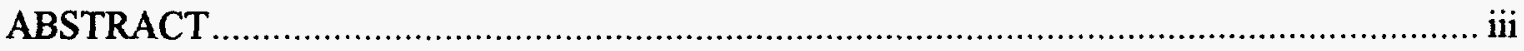

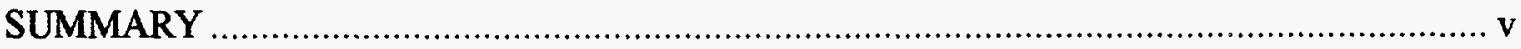

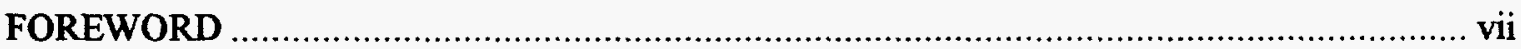

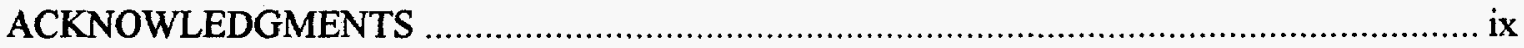

ACRONYMS

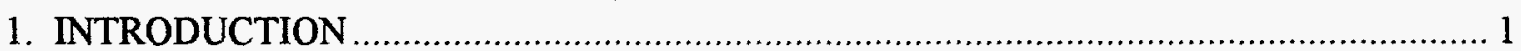

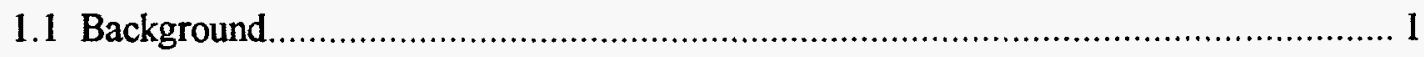

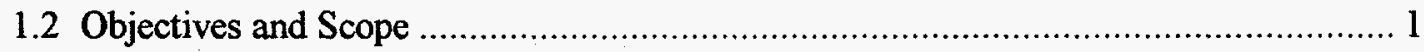

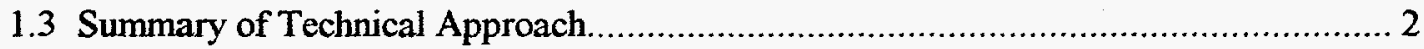

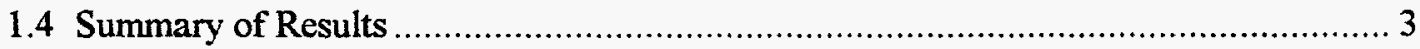

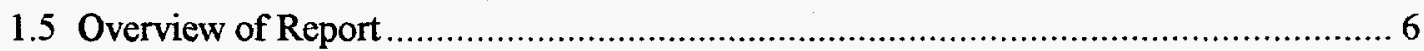

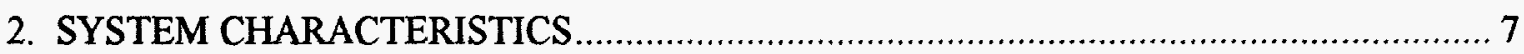

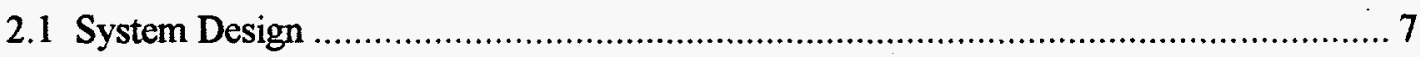

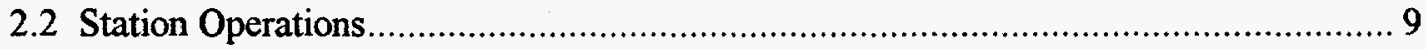

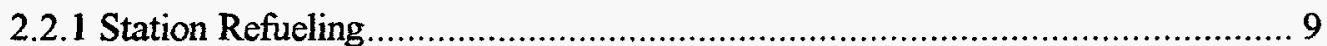

2.2.2 End User Vehicle Refueling .................................................................. 10

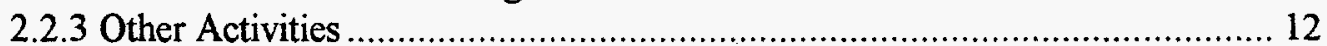

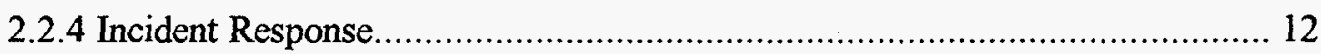

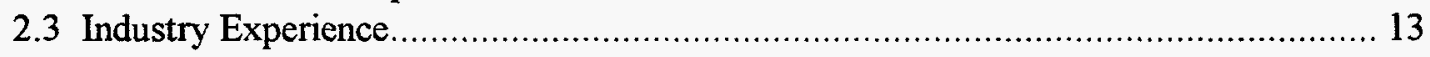

2.3.1 Experiences at Refueling/Maintenance Facilities ................................. 13

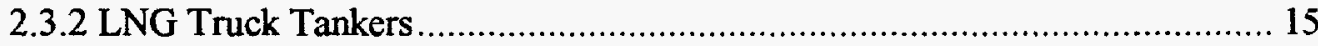

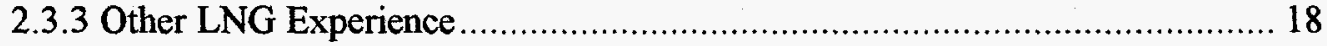

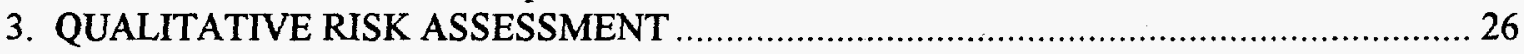

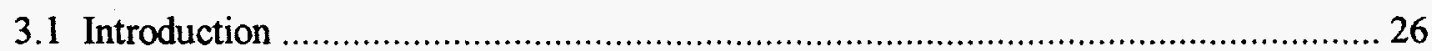

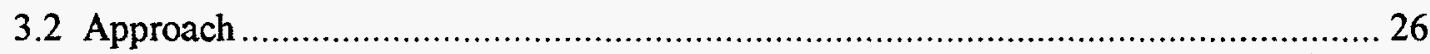




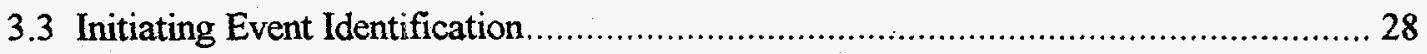

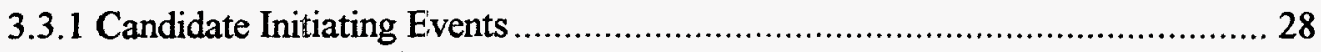

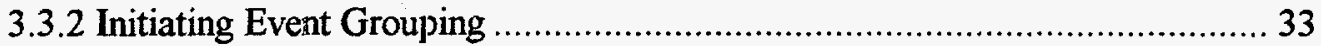

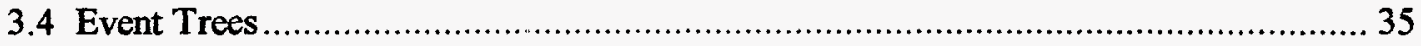

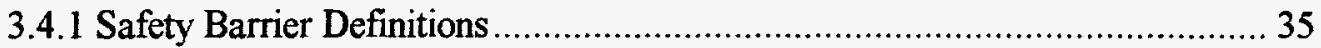

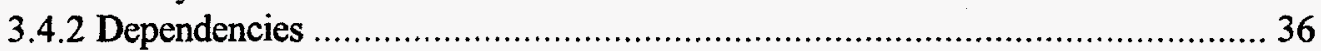

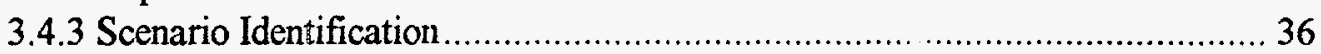

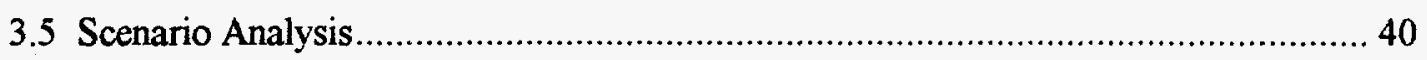

3.5.1 Scenarios with Severe Consequences …................................................ 40

3.5.2 Potentially Dominant Scenarios .......................................................... 40

3.5.3 Station Characteristics Affecting Dominant Scenarios ............................... 43

4. PHENOMENOLOGY OF LIQUEFIED NATURAL GAS .............................................. 48

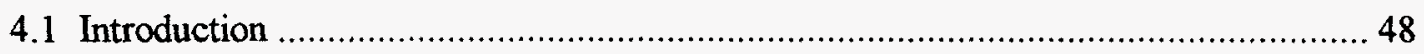

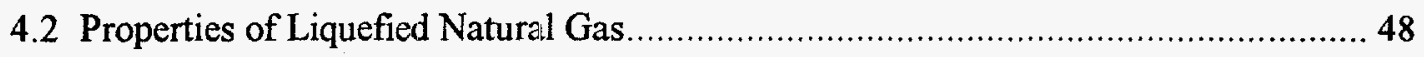

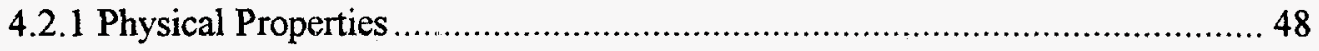

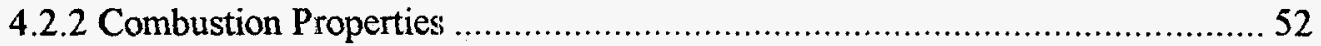

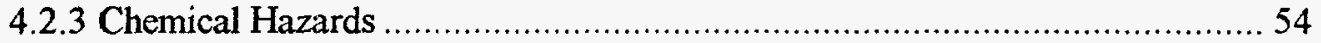

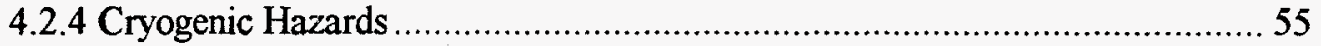

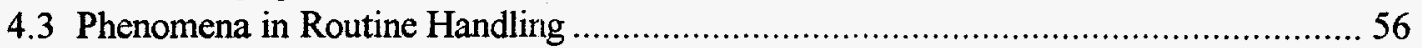

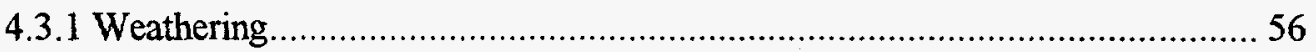

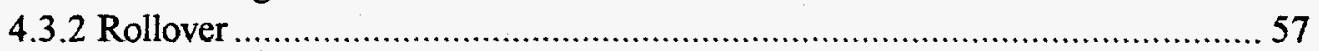

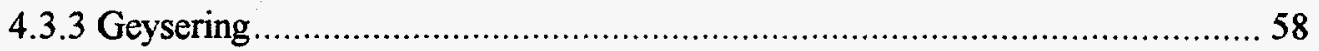

4.3.4 Static Electricity and Grounding ….................................................. 58

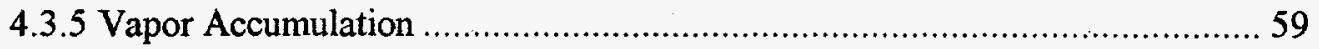

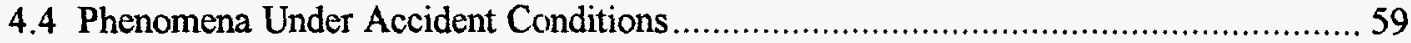

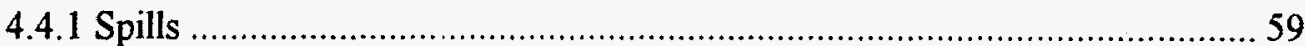

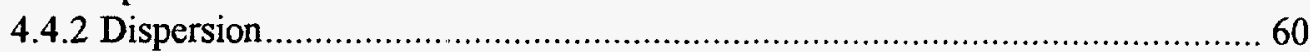

4.4.3 Boiling Liquid Expanding Vapor Explosions..........................................60 60

4.4.4 Unconfined Vapor Cloud Explosions ...................................................61 61

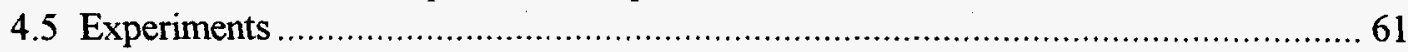

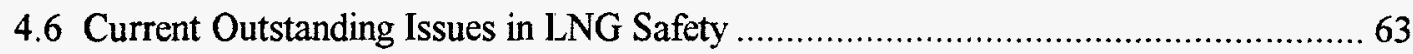

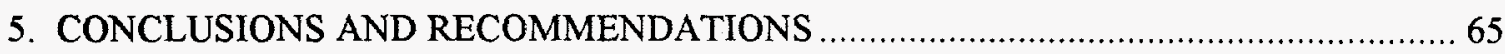

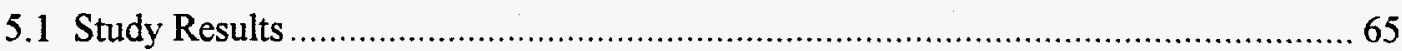

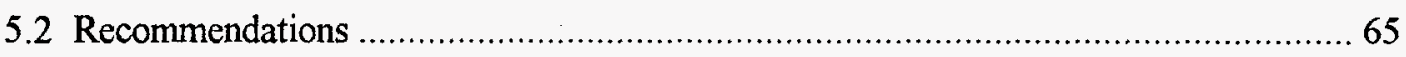

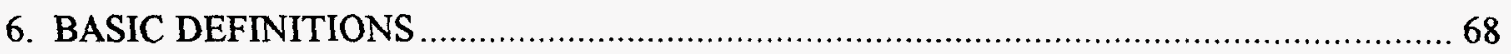


Appendix A-Failure Modes and Effects Analysis for Facility Number 1 ............................ A-1

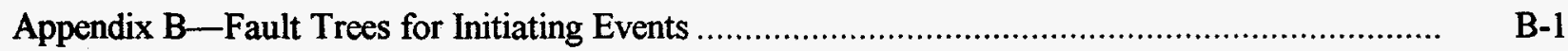

Appendix C-Event Trees for Refueling Station Qualitative Risk Assessment........................ C-1

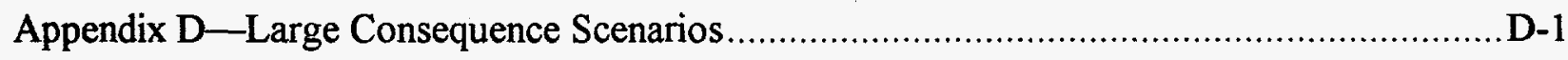

\section{FIGURES}

2-1. Example fueling system piping and instrumentation diagram....................... 8

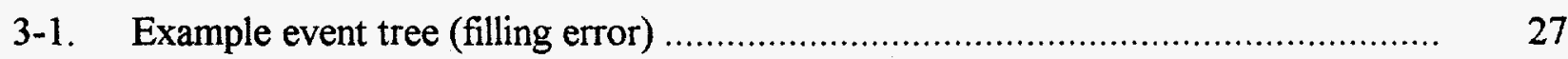

3-2. Master logic diagram: onsite serious injury or fatality ............................... 30

3-3. Master logic diagram: offsite serious injury or fatality ............................. 31

3-4. Master logic diagram continuation: LNG release .................................. 32

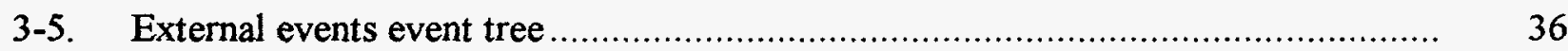

\section{TABLES}

Table 1-1. Initiating events treated in analysis. .......................................................... 3

Table 1-2. Potentially dominant scenarios. large $L N G$ release onsite ................................ 4

Table 1-3. Potentially dominant scenarios: large LNG release offsite ................................... 5

Table 2-1. Conditional probabilities of spills, given a truck accident. .................................. 15

Table 2-2. Conditional probabilities of immediate ignition, given a spill ............................ 16

Table 2-3. Conditional probabilities of delayed ignition, given a spill .............................. 16

Table 2-4. Conditional probabilities of explosion, given ignition. .................................... 17

Table 2-5. Additional events involving transportation/handling of LNG. .......................... 19

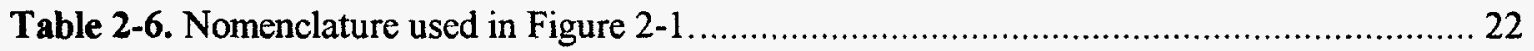

Table 3-1. Initiating events and mapping to MLD failure causes...................................... 34 
Table 3-2. Initiating event-to-top event dependency matrix.

Table 3-3. Top event-to-top event dependency matrix.

Table 3-4. Potentially dominant scenarios: large LNG release and onsite ignition. 41

Table 3-5. Potentially dominant scenarios: large LNG release offsite. 42

Table 3-6. Noteworthy site-specific features affecting initiating event occurrence 44

Table 3-7. Noteworthy site-specific features affecting top events. 46

Table 4-1. Comparison of LNG, diesel, and gasoline. 49

Table 4-2. Properties of hydrogen, methane and gasoline. 51

Table 4-3. Combustion properties of hydrogen, methane and gasoline. 53

Table 4-4. Temperature dependence of flammability limits for methane-air mixtures. 54

Table 4-5. Vapor pressures and heats of combustion for four energy gases. 56

Table 4-6. Parameters for Falcon experiments. 62 


\section{ACRONYMS}

\begin{tabular}{|c|c|}
\hline $\begin{array}{l}\text { ACGIH } \\
\text { ANS } \\
\text { ASME } \\
\text { ATA } \\
\text { BLEVE } \\
\text { CAI } \\
\text { CAU } \\
\text { CFR } \\
\text { CGA } \\
\text { CNG } \\
\text { DBT } \\
\text { DMIM } \\
\text { DOT } \\
\text { ED } \\
\text { EE } \\
\text { ER } \\
\text { FCV } \\
\text { FMEA } \\
\text { GAO } \\
\text { GF } \\
\text { GRI } \\
\text { HF } \\
\text { IE } \\
\text { LGFSTF } \\
\text { LNG } \\
\text { LPG } \\
\text { LR } \\
\text { MLD } \\
\text { NGV } \\
\text { OD } \\
\text { OF } \\
\text { OM } \\
\text { PFI } \\
\text { PFU } \\
\text { PPE } \\
\text { PRA } \\
\text { PSV } \\
\text { RC } \\
\text { RV FO } \\
\text { RV FTO } \\
\text { SFI } \\
\text { SFU } \\
\text { SI }\end{array}$ & $\begin{array}{l}\text { American Conference of Governmental Industrial Hygienists } \\
\text { American Nuclear Society } \\
\text { American Society of Mechanical Engineers } \\
\text { American Trucking Association } \\
\text { boiling liquid expanding vapor explosion } \\
\text { LNG release due to construction accident, isolable } \\
\text { LNG release due to construction accident, unisolable } \\
\text { Code of Federal Regulations } \\
\text { Compressed Gas Association } \\
\text { compressed natural gas } \\
\text { ductile brittle transition } \\
\text { Design, Manufacturing, Installation, or Maintenance } \\
\text { Department of Transportation (federal) } \\
\text { early detection } \\
\text { external event } \\
\text { early recovery } \\
\text { flow control valve } \\
\text { failure modes and effects analysis } \\
\text { Government Accounting Office } \\
\text { 'guaranteed failure' } \\
\text { Gas Research Institute } \\
\text { hose failure } \\
\text { initiating event } \\
\text { Liquefied Gaseous Fuel Spill Test Facility } \\
\text { liquefied natural gas } \\
\text { liquefied petroleum gas (usually propane) } \\
\text { late recovery } \\
\text { master logic diagram } \\
\text { natural gas vehicle } \\
\text { driveaway (operational event) } \\
\text { filling error (operational event) } \\
\text { maintenance error (operational event) } \\
\text { pipe failure, isolable } \\
\text { pipe failure, unisolable } \\
\text { personal protective equipment } \\
\text { probabilistic risk assessment } \\
\text { pressure safety valve } \\
\text { release containment (i.e. the release is contained in a secondary structure) } \\
\text { Relief valve fails open } \\
\text { Relief valve fails to open } \\
\text { seal failure, isolable } \\
\text { seal failure, unisolable } \\
\text { secondary impact prevention }\end{array}$ \\
\hline
\end{tabular}


ST

THRP

TLV

TTF

TTT

UVCE

USNRC

VA

VF

VFI

VFU storage tank failure

tetrahydrothiophene

Threshold Limit Value

truck fuel tank failure

tanker truck tank failure

unconfined vapor cloud explosion

U.S. Nuclear Regulatory Commission

LNG release due to vehicular accident

valve failure

isolable valve failure

unisolable valve failure 


\section{Qualitative Risk Assessment for An LNG Refueling Station and Review of Relevant Safety Issues}

\section{INTRODUCTION}

\subsection{Background}

As part of the efforts currently under way to increase the use of natural gas in transportation applications, technology is being developed to enable the widespread use of liquefied natural gas (LNG) as a fuel. LNG, as a cryogenic liquid, has inherently different characteristics than the gasoline and diesel fuel we are accustomed to using. These differences include the rapid evolution of a gas which is lighter than air at room temperature, the potential for cryogenic burns and changes in materials properties at low temperatures. The safe handling and use of LNG requires training and technology development. One of these technology development activities includes the performance of safety assessments for LNG systems. Such assessments can assist in the identification and prioritization of potential system weak points and associated improvements.

A failure modes and effects analysis (FMEA) has been performed for LNG-fueled trucks (ATA, 1995). Our study documents a qualitative risk assessment for LNG refueling stations, part of the necessary infrastructure for an LNG-based trucking industry.

Risk assessment is a particular type of safety analysis aimed at: a) identifying accident scenarios of potential concern, and b) determining the probability and consequences of these scenarios (Kaplan and Garrick 1981). In a quantitative risk assessment, scenario probabilities and consequences are quantified and treated in a formal mathematical framework. In a qualitative risk assessment, scenarios are prioritized based on qualitative assessments of the absolute or relative probabilities and consequences. Qualitative risk assessment (of which FMEA is one form) is often a useful prelude to quantitative risk assessment, as it can identify scenarios where analysis resources should be focused. Both qualitative and quantitative risk assessment enable the prioritization of system design and operations alternatives based on an explicit consideration of accident likelihood and severity.

\subsection{Objectives and Scope}

The overall objective of this study is to generate safety lessons and insights useful to the development of LNG refueling stations. The specific objectives of this study are threefold:

- To identify and characterize public and worker risk and safety issues associated with the operation of LNG refueling stations for long-haul trucking

- To summarize the current state of knowledge regarding LNG safety

- To develop recommendations concerning:

- Improvements to current design and operational practices 
The study scope is limited to activities within the boundaries of refueling stations. However, it does include some issues generic to all LNG handling activities. It does address issues not directly associated with the process of refueling trucks (e.g., fuel storage, station refueling, truck maintenance). The study also addresses current station designs and operational practices. Credit for improved practices since past accidents (e.g., the Cleveland tank failure in 1944) is taken as appropriate. Conversely, no credit is taken for potential future improvements in equipment or practices (e.g. in nozzles, instrumentation or interlocks). Finally, it should be noted that the analysis is performed at a generic level; hazards (e.g., storms) and faults (e.g., refueling errors) believed to be relevant to most (if not all) stations are addressed, but system-specific detailed faults (e.g., failure of a particular piping segment or relief valve) are not treated. This generic approach provides common lessons and insights for the industry but may not be detailed enough to support detailed system improvement studies.

\subsection{Summary of Technical Approach}

The approach employed in this study follows the general steps followed in most risk assessment studies. An example description can be found in (ASME 1995). A detailed description of a number of LNG stations can be found in GRI (1996).

In the system definition phase, data was gathered through site visits to three separate refueling facilities in addition to an extensive literature search. Information was collected on typical system design and operations, past events involving $L N G$, and LNG phenomenology relevant to accident occurrence and

mitigation. Special attention was paid to the review of the phenomenological data (e.g., concerning LNG flammability and dispersion) in order to see if concerns raised in an earlier report (GAO 1978) and a recent memo reiterating these concerns (Hunt 1996) are still warranted.

In the model construction phase, event trees (ANS 1980) were constructed to represent possible scenarios following an initial fault (an "initiating event"). The event tree "top events", whose successes and failures define the different possible scenarios, are based on the generic safety functions defined in (Siu et al 1995). The initiating events were identified using a variety of methods, including master logic diagrams, FMEA, review of past studies, and review of past events. The initiating events were grouped to keep the analysis tractable; grouping was performed based on considerations of accident magnitude and recoverability. The full set of initiating events considered is shown in Table 1-1. (Note that these initiators are defined in terms of LNG releases instead of the root causes of the releases.)

In the model analysis phase, accident scenarios leading to onsite ignition or offsite release were identified using the event trees constructed in the previous phase. Qualitative arguments concerning the likelihood of failure events and pairwise comparison of scenarios were then employed to identify the scenarios likely to dominate the risk from a given initiating event. Additional qualitative arguments based largely on accident phenomenology, event timing, and magnitude were then made to prioritize these potentially dominant scenarios. 


\subsection{Summary of Results}

The key results of this study are as follows.

- Sixteen potentially risk significant scenarios leading to an onsite fire or explosion and eight potentially risk significant scenarios leading to a large offsite release have been identified (see Tables 1-2 and 1-3). A number of differences in the operational practices and siting of the three facilities visited can affect the likelihood and consequences of these scenarios and need to be addressed (see below).

- Of the four safety issues raised in the Hunt memo, available data shows that two, the possibility of unconfined vapor cloud fires/explosions and the adverse effects of direct exposure to LNG vapor, are credible and of potential concern in this study. Additional study is needed to determine the quantitative risk significance of these issues. The other two issues, structural failure due to LNG exposure and the physical effects of a rapid phase transition of LNG in water, appear to be of lesser concernto the refueling station.

Table 1-1. Initiating events treated in analysis.

\begin{tabular}{ll}
\hline \multicolumn{1}{c}{ Description } & Identifier \\
\hline LNG release due to construction accident, isolable & CAI \\
LNG release due to construction accident, unisolable & CAU \\
LNG release due to external event & EE \\
Hose failure & HF \\
Driveaway & OD \\
Filling error & OF \\
LNG release due to maintenance error & OM \\
Pipe failure, isolable & PFI \\
Pipe failure, unisolable & PFU \\
Seal failure, isolable & SFI \\
Seal failure, unisolable & SFU \\
Storage tank failure & ST \\
Truck fuel tank failure & TTF \\
Tanker truck tank failure & TTT \\
LNG release due to vehicular accident & VA \\
Valve failure & VF \\
\hline
\end{tabular}


Table 1-2. Potentially dominant scenarios: large LNG release onsite.

\section{Initiating}

Event

Scenario Description

CAI Isolable release due to construction accident, guaranteed failure of early recovery efforts, ignition, failure of late recovery efforts

CAU Unisolable release due to construction accident, guaranteed failure of early and late recovery efforts, ignition

EE Release due to external event, failure of early detection, guaranteed failure of early and late recovery efforts, ignition

OD Driveaway, failure of early recovery efforts, ignition, failure of late recovery efforts

OF Release due to error during tank filling process, failure of early recovery efforts, ignition, failure of late recovery efforts

OM Release during maintenance due to error, failure of early recovery efforts, ignition, failure of late recovery efforts

OM Release during maintenance due to error, failure of early detection, guaranteed failure of early recovery efforts, ignition, faillure of late recovery

SFI Isolable seal failure, failure of early detection, guaranteed failure of early recovery efforts, ignition, failure of late recovery efforts

SFU Unisolable seal failure, guaranteed failure of early and late recovery efforts, ignition

ST Storage tank failure, guaranteed failure of early and late recovery efforts, ignition

TTF Truck fuel tank failure, guaranteed failure of early and late recovery efforts, ignition

TTT Tanker truck tank failure, guaranteed failure of early and late recovery efforts, ignition

VA Release due to vehicular accident, guaranteed failure of early and late recovery efforts, ignition

VFI Isolable valve failure, failure of early recovery efforts, ignition, failure of late recovery efforts

VFI Isolable valve failure, failure of early detection, guaranteed failure of early recovery efforts, ignition, failure of late recovery efforts

VFU Unisolable valve failure, guaranteed failure of early and late recovery efforts, ignition 
Table 1-3. Potentially dominant scenarios: large LNG release offsite.

\begin{tabular}{cl}
$\begin{array}{c}\text { Initiating } \\
\text { Event }\end{array}$ & \multicolumn{1}{c}{ Scenario Description } \\
\hline EE & $\begin{array}{l}\text { Release due to external event, failure of early detection, guaranteed failure of early and late } \\
\text { recovery efforts, failure of containment }\end{array}$ \\
OD & $\begin{array}{l}\text { Driveaway, failure of early recovery efforts, failure of late recovery efforts, failure of } \\
\text { containment }\end{array}$ \\
OF & $\begin{array}{l}\text { Release due to error during tank filling process, failure of early recovery efforts, failure of late } \\
\text { recovery efforts, failure of containment }\end{array}$ \\
OM & $\begin{array}{l}\text { Release during maintenance due to error, failure of early recovery efforts, failure of late } \\
\text { recovery efforts, failure of containment }\end{array}$ \\
ST & $\begin{array}{l}\text { Storage tank failure, guaranteed failure of early and late recovery efforts, failure of } \\
\text { containment }\end{array}$ \\
TTT & $\begin{array}{l}\text { Tanker truck tank failure, guaranteed failure of early and late recovery efforts, failure of } \\
\text { containment }\end{array}$ \\
VA & $\begin{array}{l}\text { Release due to vehicular accident, guaranteed failure of early and late recovery efforts, failure } \\
\text { of containment }\end{array}$ \\
VFU & $\begin{array}{l}\text { Unisolable valve failure, guaranteed failure of early and late recovery efforts, failure of } \\
\text { containment }\end{array}$ \\
\hline
\end{tabular}

The recommendations stemming from this study concerning refueling station design and operational practices are as follows.

- Improvements should be made in procedures and training with respect to operational practices (e.g., tank venting, use of grounding wires, use of personal protective equipment), improper responses to alarms, and the performance of maintenance.

- Station designs should account for: a) the possibility of LNG leakage along unexpected pathways (e.g., past seals) to enclosed spaces, and b) the possibility of complete LNG inventory losses. For example, methane detectors should be provided in all enclosed spaces, facilities should be designed to prevent the buildup of methane in all enclosed spaces (assuming a leak), and of appropriately sized bund walls completely surrounding the main LNG storage tank(s) should be provided.

- The dissemination of best practices among stations should be strongly supported.

These recommendations are based on field observations at three different LNG refueling stations and on information gathered from a number of papers and reports. To ensure that these recommendations are applicable to the range of refueling stations across the country, and to better define the degree of risk associated with the operation of these stations, the following studies are recommended.

- Additional facilities should be visited; the observations from these visits should be integrated with the results of this study. 
- An in-depth review of $\mathrm{LNG}$ accident/event reports (case studies) should be performed to: (a) provide a stronger link between experiential data and the failure scenarios identified in the risk assessment, and (b) identify historical failure mechanisms which are less likely or no longer relevant, due to advances in codes and standards, construction practices, operational practices, and so forth.

- A detailed review on post-1978 experimental data relevant to predicting LNG hazards should be performed to provide a more definitive picture of what is known concerning LNG dispersion and ignition under realistic accident conditions. This is needed to determine the risk significance of the two Hunt memo issues of potential concern (i.e., unconfined vapor cloud fires/explosions and direct exposure to LNG vapor).

Additional discussion on these insights and recommendations is provided in Section 5.

\subsection{Overview of Report}

Section 2 of this report describes typical LNG refueling station system design and operational characteristics, as observed in the three site visits performed in this study. Section 2 also discusses relevant industry experience and reports concerning LNG accidents. Section 3 discusses the qualitative risk assessment; it presents the methods and assumptions used to obtain the results shown in Tables 1-2 and 1-3. The section concludes with a summarization of station-specific features observed in the site visits which are relevant to the risk assessment results. Section 4 summarizes currently available information on LNG behavior under normal and accident conditions, and addresses issues identified in the GAO study and the Hunt memo. Section 5 provides a number of concluding remarks and recommendations. Details underlying the analysis (e.g., an FMEA for a refueling system, initiating event models, event trees, accident scenarios) are provided in Appendices A-D. 


\section{SYSTEM CHARACTERISTICS}

This section describes general design and operational characteristics of LNG refueling stations. This description is based on visits to three separate facilities. Facility Number 1 is a temporary, restricted access, remotely sited refueling facility servicing a privately owned and operated fleet of buses and utility vehicles. Both LNG and compressed natural gas (CNG) fueled vehicles are serviced. The main LNG storage tank has a 13,000 gallon capacity. A permanent refueling station is being built nearby, but is not included in this analysis. Facility Number 2 is a publicly accessible self-service refueling station which services both LNG and gasoline fueled vehicles. It used a 10,000 gallon parked trailer tank for the LNG at the time of our visit. The station is located in a semi-rural site (the nearest houses-trailers and factory built homes-are about 200 feet away). Facility Number 3 is a restricted access combined LNG/CNG facility servicing a fleet of public transit vehicles. It has three 20,000 -gallon storage tanks and has an urban location.

To provide a perspective on the safety characteristics of LNG and LNG handling, this section also discusses information on historical accidents involving $\mathrm{LNG}$.

\subsection{System Design}

This section describes a typical LNG refueling system. Many of the details (e.g., the parameter values) are derived from the system at Facility 1 (see Figure 2-1). Comments on variations in design are provided as appropriate within the text.

The basic system centers around a large storage tank of around 13,000 gallon capacity held at an average pressure of 30 to $150 \mathrm{psig}$ (many storage tanks operate at the $40 \mathrm{psig}$ range). The LNG is maintained at about $-260^{\circ} \mathrm{F}$ at atmospheric pressure and about $-128^{\circ} \mathrm{F}$ at $40 \mathrm{psig}$. The storage tank is mounted on steel supports rather than buried underground. (Most petroleum fuel tanks are buried, apparently to protect them from the heat of hot days and fires at the site, and vehicle collisions.) A berm or dike (either metal, concrete, or earth) several feet in height is provided around the LNG storage tank as an impoundment area in case there is a tank leak (see 49CFR193.2149). In such a case the berm is intended to confine the liquid while it vaporizes, and to ensure that the vapor rises in the immediate area of the tank.

The storage tank is double walled, with a stainless steel inner tank that withstands cryogenic temperatures, and an outer wall of mild steel that cannot withstand cryogenic temperatures. Both the inner and outer vessels may use stiffening rings to give structural strength. The inner tank is supported or suspended inside the outer vessel using low thermal conductivity materials such as stainless steel. The tank annulus is evacuated to low pressure (on the order of $10^{-5}$ Torr) to reduce convective and conductive heat transfer from the ambient temperature outer vessel to the inner vessel. Some form of solid insulation, such as layers of foil sheeting (multilayer insulation) or perhaps granular pearlite (older technology), is used in the annulus to retard radiant heat transfer from the outer vessel to the inner vessel walls. The storage tank inner vessel is protected by pressure relief valves (usually set at $110 \%$ of design pressure) and rupture disks (usually set at $120 \%$ of design pressure) in case of overpressure. The annulus is also protected against overpressure by a rupture disk that opens at a pressure level of perhaps 5 to 7 psig. This protection prevents inner vessel buckling if the annulus is pressurized.

A thermally insulated pipe from the storage tank connects to a smaller volume pressure tank (300 gallons in one facility; 500 gallons in another). The pressure tank is similar in design to the storage tank; it has a vacuum insulation annulus and pressure relief protection. The pressure tank houses a 


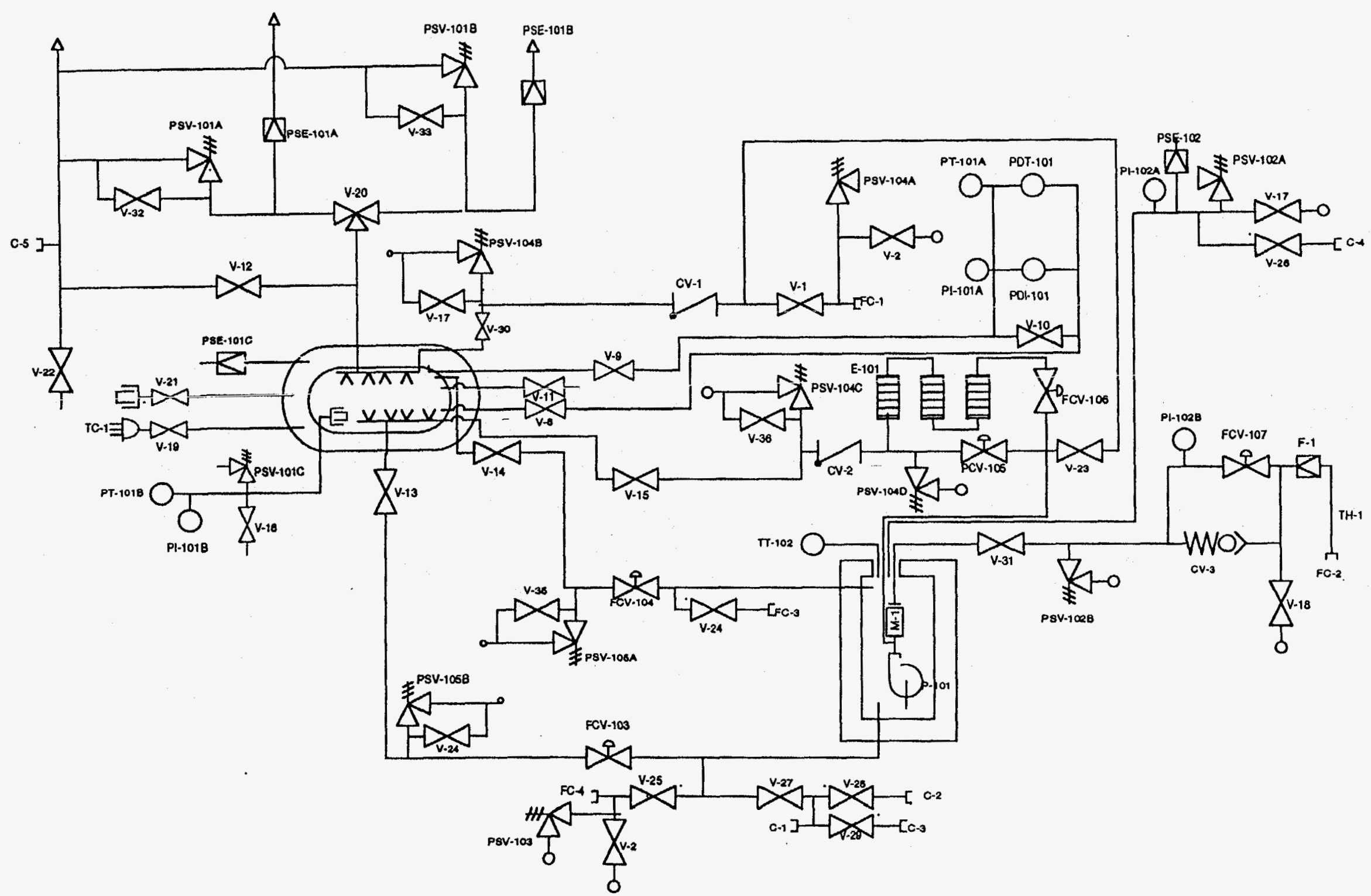

Figure 2-1. Example Fueling System Piping and Instrumentation Diagram 
submerged centrifugal pump. The pump keeps the saturated LNG in the pressure tank at a high enough pressure (e.g., under $200 \mathrm{psig}$ ) to fill a vehicle fuel tank, which usually operates between 110 and $180 \mathrm{psig}$. (Note that the vehicle fuel tank relief valves at facility 1 are set at about $235 \mathrm{psig}$-vent to vehicle stackand 350 psig-vent to vehicle fuel tank compartment. If a high pressure pump is selected, scenarios where the pump pressurizes the pressure tank past the setpoint of the vehicle's first relief valve may be possible. Generally, the pressure pumps have only a 60 to 85 psi differential pressure.) Refueling flow rates are up to 50 gallons/minute; to refill a vehicle can require on the order of 4 minutes dispensing time. The vehicle LNG tanks at Facility 1 are kept over $10 \%$ full to avoid completely emptying the tank; the remaining LNG keeps the tank at cryogenic temperatures. If the tank warms to room temperature, it is called a 'hot tank', and must be recooled to cryogenic temperature by refilling with LNG; much boiled LNG is vented in this cooldown process; fortunately the time to warm an empty tank can be long (perhaps a day). If the refueling station also services CNG-fueled vehicles, the boiled LNG may be routed to the compressors of the CNG fueling system (instead of venting to the atmosphere).

Pneumatic or solenoid operated flow control valves are used between the storage and pressure tanks. From the pressure tank, valves control flow to the vehicle fill line. There is also a reverse flow check valve in this section of piping to stop any flow from the vehicle tank to the pressure tank. The flexible metal fuel transfer hose has a special nozzle fitting with a two-handle positive locking clamp and a pintle-operated flapper valve so that the fill line must be connected to a vehicle before LNG can flow past the valve and into the vehicle fuel fill line. The vehicle fill line also has an anti-reverse flow valve. Operators can use a small diameter vent line to purge gas from the vehicle fuel tank ullage (the space above the liquid). This process reduces the tank pressure and can speed up the refueling process. The vented natural gas is routed up the small stack that protrudes on the top of the vehicle.

From the pressure tank, a pipe routes a small portion of LNG to a vaporizer that boils the LNG to saturated vapor conditions in a finned vaporizer attachment which uses heat from the ambient air. This type of vaporizer is called an ambient vaporizer. The boiled natural gas is returned to the ullage of the station's storage tank to maintain its pressure as the liquid level in the tank lowers during vehicle fueling operations.

Other valves are used for filling the storage tank, for isolating tank instrumentation, for taking LNG samples (to test for composition and purity), and for pressure relief protection of any pipe that could suffer LNG 'lock in'. ('Lock in' is a term that means the trapping of a cryogen in an enclosed volume such as a pipe section between two closed valves. If the liquid boils without pressure relief, the trapped volume of LNG will increase in pressure up to $9000 \mathrm{psig}$ in warming from $-260^{\circ} \mathrm{F}$ to $+70^{\circ} \mathrm{F}$.)

\subsection{Station Operations}

\subsubsection{Station Refueling}

Since none of the facilities visited have natural gas liquefaction facilities on site, replenishing the LNG inventory in the storage tank is accomplished by deliveries from a tank truck. The rate of delivery naturally depends on the station usage; for the facilities visited, the delivery rates vary from around once per day to once or twice a month. The transfer process nominally proceeds as follows (see Figure 2-1). This description is based on discussions with facility \#1 personnel and review of station design diagrams.

At Facility 1, the tank truck uses a flexible hose for the bottom fill operation, the liquid hose connected at connector FC-4. (Valve V-25 must be opened. Note that an alternative is to top fill the 
storage tank through connector FC-1.) The tank truck centrifugal pump is used to pump LNG into the system. The tank truck pressure is on the order of $40 \mathrm{psig}$, so pumping is needed to pressurize the LNG to system pressures. The transfer generally is performed using 4 inch diameter lines that can provide flow in the 400 to $500 \mathrm{gpm}$ range. Fuel transfer is metered when leaving the tank truck.

With proper flow velocity, there is adequate mixing of the new liquid emerging from the bottom sparger with the existing liquid in the storage tank, so LNG stratification by temperature (i.e., rollover) concerns are avoided. As the liquid level increases, the storage tank gas pressure increases and vapor collapse occurs.

Depending on the facility, fuel delivery is performed by the delivery truck driver or by a dedicated facility refueling technician. In either case, the fueler is supposed to wear personal protective equipment (PPE) consisting of cryogenic gloves, shield glasses/face shields, and, perhaps, a rubber apron. Remotely operated emergency shut off valves are provided to stop flow in case of a hose breach or loss of hose seal. Tank trucks are bonded to dissipate static electric charge buildup when fluid flows. A bonding wire to the system and a grounding wire to the earth may be provided to ensure proper dissipation of static electricity for the fuel transfer.

\subsubsection{End User Vehicle Refueling}

As in station tank filling, end use vehicle refueling requires both filling of the fuel tank with liquid and venting of the tank ullage. Depending on the facility, refueling can be performed by the vehicle driver or by a dedicated technician. At Facility Number 2 (the self-service station), the nominal procedure is as follows.

The driver pulls his or her vehicle up next to the LNG island, turns off the engine, sets the parking brake, and gets out. The driver then authorizes the refueling at a keycard reader about 8 feet from the pump, dons personal protective equipment (gloves, safety glasses, apron), opens the fuel door on the vehicle, attaches the grounding wire, removes the nozzle from the pump, attaches it to the fill connection, and then stands back to wait while refueling occurs.

As part of the automatic refueling process, the Facility 2 system uses the (single) refueling hose to alternately vent and fill the vehicle fuel tank. It has a 30 to 45 second cycling time before starting to vent or fuel. In addition, the system automatically vents the nozzle and hose before and after use, so that no LNG is present during attachment and disattachment of the nozzle. The system will also automatically try to cool down a warm tank, that is, it will cycle through a vent, fill, vent pattern. The system will go through this cycle 3 times before it automatically turns off. Sometimes the system interprets the pressure spike when LNG enters a warm tank as an indication that the tank is full and thus a tank may not fill all the way. In such a situation, to finish refueling, the driver has to use the keycard to reauthorize fueling.

Upon completion of refueling, the driver detaches the nozzle and grounding wire, replaces these within the fuel pump barriers, closes the fuel door, takes off the PPE, gets in the vehicle and drives away.

This same basic process is also used at Facilities 1 and 3, although there are some differences due to: (a) system design differences (e.g., Facility 1 does not require automatic venting), and (b) the use of trained fueling technicians at Facility 3. The technicians typically work in shifts and are supervised. As compared with drivers who refuel their own vehicles, they might be expected to better adhere to procedures and safety regulations and avoid short-cuts (because of the nature of their training and supervision). We note that 
deviations from this expectation were observed during sample site visits (e.g., involving the use of grounding wires).

Some safety-relevant variances from the nominal procedure observed by or related to the authors during this study's site visits are as follows:

- Engines left running during refueling

- $\quad$ Parking brakes not set

- Lack of use of PPE

- $\quad$ Lack of use of grounding wire

- Manual operation of fuel tank vent valve to cool off the fuel tank and speed up refueling

- Failure to remove hose followed by driveaway. Note that hose breakaway sections are a routine component at the stations visited. These devices limited the amount of LNG lost in the driveaway events.

Regarding the use of grounding wires, it is not clear that these are necessary for safe operation of the system. (Some industry professionals question whether there is any risk since they have not seen static electricity buildup or arcing for non-grounded systems.) However, situations where they are administratively required but ignored by users may reflect a poor general attitude towards safety.

Manual operation of the fuel tank vent valve was observed at one of the facilities visited. This was done by drivers to avoid having to wait for the system to automatically cycle or to avoid having to reauthorize fueling (a lengthy process). No formal instructions or even encouragement had been given on the use of vent valves; the process had been spread by word of mouth. As a result, misuse occurred. Some drivers used the vent valve to excess (just to make sure the system wouldn't cycle to venting); considerable quantities of LNG (condensed vapor cloud several feet in diameter) were observed coming out of the truck vent pipes. Some drivers used the vent valve at the wrong time (resulting in no effect and no change in system performance); they used it because they had heard it sped things up, but they really didn't understand what they were doing.

Driveaway events, in which the vehicle is driven away while the fill line is still connected and which are relatively common events at conventional fueling stations, have not yet been observed at Facility Numbers 1 or 2 . They have been observed at Facility Number 3 . The hose is provided with a coupling designed to break if a driveaway occurs. Isolation valves are also provided to prevent significant fuel loss from the station or from the vehicle. Events involving vehicle driveaway with the grounding wire still attached have been observed at Facility Number 2; these have resulted in essentially no damage to the grounding wire clamp or the vehicle.

a. The variances on this list are not necessarily common occurrences; however, they have been observed by this study's authors or by station personnel interviewed by the authors. 


\subsubsection{Other Activities}

The variety of non-refueling activities taking place at the refueling station depends on the roles played by the station. For example, Facility Number 1 is essentially dedicated to LNG/CNG vehicle refueling; other vehicle activities (e.g., vehicle maintenance) occur well away from the refueling island. At Facility 2, the LNG station is co-located with a gasoline station/convenience store. However, the convenience store personnel do not operate the LNG station. The maintenance shop is located about five: miles from the station. Facility Number 3 is a full service LNG/CNG refueling facility; the maintenance shops are onsite.

Maintenance of the station systems depends on the expertise and commitment of the station personnel. Station personnel were unaware of written procedures, checklists, or worksheets for operations or maintenance. Preventative activities can involve regular walkdowns of the system and regular examination of system parameters monitored by the computer. Other maintenance activities include dealing with valve stem packing leaks (tightening) and nozzle leaks (replacement). Lessons are often learned by trial and error; facilities with years of experience (e.g., Facility Number 3) may have smoother operations.

\subsubsection{Incident Response}

The LNG fueling facilities visited have methane detectors and manual emergency shutdown devices that trigger remote alerts to surveillance personnel (on site or nearby). Designated staff affiliated with the fueling facility are trained to respond to alarms. Their responses may range from simply resetting the system following an erroneous shutdown, to using special fire extinguishers (e.g., Purple K-potassium bicarbonate) to put out small fires. For larger incidents, emergency response teams will need to be called in.

Fire departments local to LNG stations may have been specifically trained to contain a spill or fire. Since water and traditional extinguishers can exacerbate an LNG fire, response teams need to be properly prepared. Training programs for fire emergency management are provided by several organizations across the country. To aid firefighters, LNG stations must display a placard designed by the NFPA. The placard is required by U.S. DOT regulations. The placard is a four-part diamond showing the type of hazard being faced.

Responses to incidents will vary from facility to facility. Some potential concerns with incident response include:

- Manual overriding of alarms or emergency shutdown signals

- Possibly delayed responses to emergencies

- Lack of training/procedures for a major leak.

Regarding the first issue, the emergency shutdown buttons have been accidentally actuated a number of times at one of the facilities visited, due to their poor location. (One such accidental actuation was observed during the site visit.) The station users have been informed that they may use the reset button once; if the system trips off again, they are to leave the station and call the designated response personnel. Such a response procedure, while understandable in motivation, may lead to an incorrect action in the event 
of a real emergency. (Operator neglect and/or override of alarms due to previous false alarms has been a prime contributor to a number of significant oil spill events, as described by Siu et al, 1995.)

Regarding the second issue, one of the sites visited is monitored remotely. However, the designated response personnel may be 5 to 20 miles away, depending on the time of day and the activities at the station. Clearly, delays in notifying the response personnel and in getting these personnel to the site may be long enough to preclude effective action (in the event of a major incident). There have been times when an emergency shutdown has occurred and the station alert signal (a flashing red light) has been on but the response personnel were not notified.

Regarding the third issue, two of the facilities visited appear to have no written procedures for emergency response and no equipment such as protective suits or self-contained breathing apparatus. The staff at one facility, when asked what they'd do in response to a major leak, candidly replied, "Run."

\subsection{Industry Experience}

This section summarizes information collected on LNG refueling station events and on events potentially relevant to LNG refueling stations. It also discusses information collected from a number of safety studies relevant to this study.

\subsubsection{Experiences at Refueling/Maintenance Facilities}

Based on interviews conducted during the site visits, none of the facilities visited have experienced a major LNG accident. Discussions with industry representatives showed that there have not been any major LNG accidents at refueling stations. Some of the common events experienced include system leaks (e.g., valve stem packing leaks and fuel transfer nozzle leaks) and driveaways. One facility visited had experienced a spill of 200 gallons of LNG; this involved a vehicle fuel tank union coming loose. The spill pooled underneath the vehicle but eventually dissipated into the atmosphere without igniting. There was no collateral damage to the vehicle or its tires.

One disadvantage of LNG (as compared with CNG) is the current inability to odorize the fuel. Odorant may not be a benefit at a refueling site where small leaks will regularly occur, but odorant in a vehicle fuel system would be an advantage for detection by the operator or passengers. The LNG industry relies on methane detectors since odorant is not practical. Because the unodorized vapors are difficult for humans to detect, gas leaks in confined areas are particularly dangerous. In 1993, technicians performing maintenance on an LNG-fueled bus noticed a fuel leak. When they removed a floorboard to access the fuel system, a significant amount of gas from vaporizing LNG accumulated in the bus compartment. The onboard methane detection system was triggered, and shut down the bus as designed. The technicians, however, decided to override the system and attempt to drive the bus out of the maintenance garage. When the ignition switch was turned, a circuit breaker arc ignited the accumulated methane inside the bus, resulting in a small explosion. The technicians were not injured but the bus windows were destroyed.

This event provides further illustration of the potential seriousness of the problem discussed in Section 2.2.4 and by Siu et al (1995): neglect and/or overriding of alarms, which may be habitual and even sanctioned, sometimes leads to serious consequences. It should be noted that following this event, several preventative measures were implemented at the company that owned the bus. Self-venting roof hatches were installed in all LNG buses. Vehicle equipment inspection and maintenance programs were formalized. 
Training and procedures were implemented for safe practices. These measures have been duplicated by other programs.

Other incidents reported by the industry (NGV 1996) have involved minor injuries due to cryogenic liquid burns from LNG during refueling and superficial burns from methane vapor flash fires during fuel system dismantling. In one case, an untrained worker received cryogenic burns to his hands while handling the LNG refueling components. Another instance resulted in a worker's beard being singed when methane was released from a dismantled LNG fuel system and was ignited.

A risk assessment has been performed for indoor refueling of mass transit buses (SAIC 1990). Although the study deals with diesel and CNG rather than LNG, it is of interest because it addresses refueling issues. Note that CNG tanks are not insulated, whereas LNG tanks are double-walled steel cryogenic storage vessels. Normally the vacuum insulation has a temperature difference of about $200^{\circ} \mathrm{K}$ and maintains the fuel as a liquid for several days. During a fire the temperature difference would be as much as $1200^{\circ} \mathrm{K}$, shortening the hold time by a factor of about six. Industry tests have shown that shortduration (10-15 minute) fires do not increase the fuel pressure.

The five postulated accident scenarios compared in the SAIC study were:

1. A CNG bus with one-quarter full tanks is brought in for maintenance and is exposed to a fire in the shop (careless disposal of smoking materials or an industrial fire).

2. A bus with full CNG tanks is brought in for maintenance and is exposed to the same fire postulated in scenario 1 . This bus vents much more gas due to full tanks.

3. A bus is refueled inside a dual fuel shop (CNG and diesel fuel present). The bus leaks $\mathrm{CNG}$ and an ignition source is present.

4. A CNG bus is refueled inside a dual fuel shop (CNG and diesel fuel present); the bus is segregated from the diesel portions of the shop. The bus leaks $\mathrm{CNG}$ and an ignition source is present.

5. The same scenario as number four but with a dedicated indoor CNG refueling area.

Scenario 3 was found to be the most likely. The parameters most affecting the probability of this and the other scenarios were the human error and relief valve failure rates. (The analysis used generic failure rates from a variety of sources-apparently none of which include LNG or CNG industry experience-when quantifying the likelihoods of the scenarios.) The study made the following recommendations:

- Develop redundant safety systems to keep refuelers from introducing ignition sources

- Ensure that operators are regularly trained and tested

- Develop faster responding gas detection systems

- Ensure proper maintenance of redundant ventilation and exhaust fans

- Establish uniform indoor refueling standards and strictly enforce these standards. 
Attempts to collect raw data on events at gasoline service stations and truck stops have been unsuccessful to date. No gasoline station operating experience reports or data compilations were found in the literature. Contact with the US Department of Transportation (USDOT) revealed that they do not collect these data. A detailed search for events (e.g., through reviewing data collected by fire departments or insurance companies, or through reviewing newspaper accounts) was judged to be beyond the scope of this study.

\subsubsection{LNG Truck Tankers}

One refueling station accident of potential concern involves LNG truck tankers, as these carry considerably more LNG (on the order of 10,000 gallons) than a typical LNG fuel tank (on the order of 200 gallons). While this study has not identified any information on significant truck tanker accidents at refueling stations (see the previous section), information is available on truck tanker highway accidents.

LNG truck tanker highway accidents are not common events, due to the relatively low amount of volume transported. The GAO report cites 11 accidents occurring over the time period 1971-1977 (GAO 1978). Of these accidents, one involved the release of about $20 \%$ of the truck tank inventory and another involved the release of about $5 \%$. The rest of the accidents apparently had little or no release. None of the 11 accidents involved ignition of the LNG (although one of the events involved a gasoline fire). The GAO report does report a number of propane tanker truck accidents that did lead to release and ignition.

A continuation of this risk assessment would be to investigate the transportation of other cryogenic fluids, such as nitrogen, oxygen, and hydrogen, to determine the safety of highway transport. Initial review of the USDOT transportation incident $\log$ indicates that there have been few cryogen transport accidents.

A quantitative risk assessment has been performed in 1991 on the transport of propane, gasoline, ethyl alcohol, and hydrogen on selected highway segments (Kazarians 1997). In that study, the overall truck accident frequencies range from $6 \times 10^{-7}$ per vehicle-mile-year to $1 \times 10^{-5}$ per vehicle-mile-year, based on route-specific data. The conditional probabilities of spills given an accident, of ignition (immediate and delayed) given a spill, and explosion given delayed ignition are shown in Tables 2-1 through 2-4. (These probabilities reflect an outdoor environment; different probabilities are used for accidents in tunnels.) The probabilities are based either on experiential data or engineering judgment; the study uses the results of earlier transportation risk studies on gasoline (Rhoads 1978) and propane (Geffen 1980) to provide some of the bases for its assumptions.

Table 2-1. Conditional probabilities of spills, given a truck accident.

\begin{tabular}{lccc}
\hline \multicolumn{1}{c}{ Fuel } & Small Spill $^{\mathrm{a}}$ & Large Spill $^{\mathrm{a}}$ & Total $^{-}$ \\
\hline Propane & 0.075 & 0.025 & 0.10 \\
Gasoline & 0.09 & 0.07 & 0.16 \\
Ethyl alcohol & 0.09 & 0.06 & 0.15 \\
Hydrogen & 0.06 & 0.02 & 0.08
\end{tabular}

(Kazarians 1997)

a. "Small spills" involve $10 \%$ of tank inventory; "Large spills" involve $100 \%$ of tank inventory. 
Table 2-2. Conditional probabilities of immediate ignition, given a spill.

\begin{tabular}{lcc}
\hline Fuel & Small Spill $^{\mathrm{a}}$ & Large Spill $^{\mathrm{a}}$ \\
\hline Propane & 0.25 & 0.75 \\
Gasoline & 0.15 & 0.50 \\
Ethyl alcohol & 0.20 & 0.60 \\
Hydrogen & 0.50 & 0.90
\end{tabular}

(Kazarians 1997)

a. "Small spills" involve $10 \%$ of tank inventory, "Large spills" involve $100 \%$ of tank inventory

Table 2-3. Conditional probabilities of delayed ignition, given a spill.

\begin{tabular}{lcc}
\hline \multicolumn{1}{c}{ Fuel } & Small Spill $^{\mathrm{a}}$ & Large Spill $^{\mathrm{a}}$ \\
\hline Propane & $0.68^{\circ}$ & $0.23^{\mathrm{n}}$ \\
Gasoline & 0.04 & 0.05 \\
Ethyl alcohol & 0.04 & 0.04 \\
Hydrogen & $0.45^{\prime \prime}$ & $0.09^{\prime \prime}$
\end{tabular}

(Kazarians 1997)

a. "Small spills" involve $10 \%$ of tank inventory; "Large spills" involve $100 \%$ of tank inventory.

b. Total contribution from scenarios involving: a) ignition when the vapor cloud edge is over the population edge, and b) ignition when the vapor cloud center is over the population center. 
Table 2-4. Conditional probabilities of explosion, given ignition.

\begin{tabular}{lc}
\multicolumn{1}{c}{ Fuel } & All Spills \\
\hline Propane & 0.33 \\
Gasoline & - \\
Ethyl alcohol & - \\
Hydrogen & 0.50
\end{tabular}

Kazarians, 1997

a. "Small spills" involve $10 \%$ of tank inventory, "Large spills" involve $100 \%$ of tank inventory.

This fuel transport risk assessment does not analyze LNG truck tanker accidents. The limited GAO data on LNG truck accidents discussed above indicate that the LNG spill probability may be less than or equal to the propane spill probability (where a release occurs in roughly $10 \%$ of all reportable tanker truck accidents and a large release occurs much less frequently). The physical characteristics of LNG tanks (low pressure, stainless steel, double walls ${ }^{b}$ ) also provide an argument that the LNG spill probabilities should be lower than those for propane. (A similar argument is used in the risk assessment to reduce the large spill probability for ethyl alcohol tank trucks.) However, this argument cannot as yet be supported by the data.

Regarding ignition, the fuel transport risk assessment does not strongly distinguish between the various fuels considered with respect to immediate ignition. (The ignition probabilities do not vary by orders of magnitude.) On the other hand, it states that gasoline and ethyl alcohol do not "demonstrate much vapor dispersion" and therefore employs order of magnitude lower delayed ignition probabilities for these fuels. It should be emphasized that since the report's ignition probabilities appear to rely heavily on engineering judgment; further investigation is needed to determine if these probabilities accurately reflect: (a) current event experience, and (b) the appropriate ignition probabilities for LNG.

More recently, GRI (1994) has published a report on safety issues of LNG fueled vehicles. Areas with higher cryogenic leakage risk are differentially cooled sections, areas where hose or seal chafing can occur, areas where pipes or hoses could be stressed, sections that trap cryogens (cryogens boil and build pressure), and areas near relief valves. The report observes that LNG spills tend to occur in systems that are initially being cooled down, during fuel transfers, and during LNG sampling. LNG releases can lead to fires and vapor cloud deflagrations. The report also points out that breathing cold vapors from LNG evaporation or boiling can damage the lungs.

b. Note that the double wall design provides an additional defense against immediate releases due to impact. However, it does not provide complete redundancy; if the outer wall fails, air will leak in and the LNG will heat up, boil, and eventually escape out of the tank relief valves. 


\subsubsection{Other LNG Experience}

This section discusses experiences with LNG and other cryogens used for automotive fuel. Since LNG has been used for a fuel gas (i.e., household use in stoves, water heaters, and furnaces; industrial use as a heat source), there is a breadth of experience in the literature. Two notable events involving LNG are the Cleveland tank failure and explosion in 1944 and the Cove Point leak and explosion in 1979.

In the Cleveland event (October 20, 1944), a cylindrical storage tank owned by the East Ohio Gas Company cracked and failed, releasing 144,000 $\mathrm{ft}^{3}$ ( $10^{6}$ gallons) of LNG. Most of the LNG vaporized and dispersed, but some LNG overflowed the bund wall and entered the surrounding storm sewers. (The wall had been designed assuming that the LNG release would be relatively slow, resulting in a slowly rising pool level and significant evaporation. Thus, it was not sized to contain the entire tank inventory, nor was it designed to prevent overflow by the LNG wave resulting from the rapid, catastrophic tank failure.) The dispersing gas ignited from multiple ignition sources and the flames ignited gas in the sewers. The fire caused failure of the supports of another tank, whose inventory was added to the fire. Flames over 2,800 feet high were reported, and there was destruction over a quarter mile radius from the cylindrical tank. 128 people died in this event and hundreds more were injured. Property damage was estimated to be over $\$ 6.8 \mathrm{M}$ in 1944 dollars (BOM 1946).

Lessons from this event include: (a) the need to site large quantities of LNG more remotely, (b) to not use 3.5\% nickel steel for tanks, (c) to build higher bund walls, and (d) to preclude ignition source contact with flammable gas clouds (Zabetakis 1967).

In the Cove Point accident (October 6, 1979), a submerged pump for LNG transfer began leaking past an electrical power wire penetration. Natural gas vapors leaked into a conduit and accumulated in an electrical junction box located in a switchgear building some distance away from the leak. Although the site had methane detectors, there were none in the building. When plant personnel performed a routine operating check in the switchgear room, they noted leaking vapor. Two operators decided to remove power from the pump so that it would not start and make the leak worse. The operators opened the motor starter and an electrical arc from the control circuit apparently ignited the methane gas, killing one man and injuring the second. There were no offsite consequences. As a corrective action, ventilated cabinets were installed to route any gas to a non-hazardous location and disperse any leaks to the atmosphere (PAR 1980).

This event, while less severe than the Cleveland accident, is notable because the natural gas vapors propagated along an unanticipated pathway into a confined space. Another gas leakage event occurred in an LNG plant in Montreal in 1972. Here, the gas leaked through an air line into the plant control room and ignited (Van Horn and Wilson 1977). Design guidelines were revised after the Montreal and Cove Point accidents to preclude future occurrences.

A report on LNG plant operating experiences gives insights into the types of events and accidents that have occurred in peakshaving plants. These plants deliver natural gas fuel when needed to augment the natural gas supply to meet the peak usage demand for residential and commercial usage. Peakshaving plants store LNG during seasons of low demand and distribute gas to the pipeline distribution system during seasons of high demand. Some of the components used at these facilities are similar to those used in refueling stations. A major difference is that a peakshaving plant handles and vaporizes very large quantities (up to a billion cubic feet of gas per day) of LNG. Another difference is that pipeline quality gas stored at a peakhaving plant contained higher percentages of ethane and propane than the fuel used for LNG vehicles. 
Reviewing peakshaving plant experiences can give insights into component faults. The off-normal events that have occurred at peakshaving plants are: cold spots in storage tanks due to insulation settling, failure of tank foundation heating systems, vaporizer fires, small leaks from valve stems, piping gasket leaks, pump leaks, gas sensor false alarms (due to high winds, and sensor deterioration), false alarms of thermal radiation sensors, damaged thermal sensors during venting operations, fire protection system freeze-up due to cold weather, a few major leaks of gas (over 100,000 cubic feet of gas), electrical equipment fires not involving natural gas, and a few natural gas fires involving vaporizers (Welker and Schorr 1979). Due to the facility differences discussed above, some of the phenomena discussed for peakshaving plants, e.g. vaporizer fires or tank foundation heating system failures, are not pertinent to LNG refueling stations. However, these experiences do indicate a need for routine maintenance of gas sensors, seals and the rest of the LNG confinement boundary.

It is important to note that some of these events are not directly relevant to refueling stations. For example, the refueling stations considered in this study do not use large foundation tanks for storage. Instead, they use pressure vessel tanks mounted above ground. As another example, the vaporizer used at peakshaving plants to quickly heat up LNG employs a combustion process and undergoes high thermal and pressurization stresses. The vaporizers for refueling stations are passive ambient-temperature vaporizers and deal with small quantities of LNG. The vaporizers in refueling stations are used to bring the liquid close to saturation, rather than to produce large quantities of room temperature vapor.

Finally, Table 2-5 lists a number of accidents involving the transportation and handling of LNG. This table includes the $11 \mathrm{LNG}$ trucking accidents referred to in Section 2.3.2. Many of the other accidents

Table 2-5. Additional events involving transportation/handling of LNG.

Methane Progress, December 25, 1964

Fire at the forward vent riser ignited by lightning during unloading at the receiving terminal resulted in a six-hour delay in unloading. Prompt crew reaction extinguished the flaring without damage. (Frondeville 1977)

Jules Verne, Voyage 2, 1965

During loading, LNG tank was overfilled, causing a liquid spill from vent riser. A foreign object jammed in the float track prevented proper indication of liquid level by liquid level gage. The tank cover and a deck stringer plate fractured. (GAO 1978), (Frondeville 1977)

\section{Methane Progress Voyage 14, May 1, 1965}

At disconnection of loading arms, LNG spilled from ship's crossover line. Seating of the liquid leading valve was prevented by a piece of a failed Teflon valve facing that lodged between valve disc and seat. The drip pan overflowed due to water being projected onto it. A minor deck plating crack occurred. (GAO 1978)

Polar Alaska, November 19, 1969

During LNG loading at Kenai, Alaska, gas leaking was detected at the No. 1 cargo tank primary barrier on the $71,500 \mathrm{~m}^{3}$ Gas Transport membrane LNG carrier. Invar strakes creased in numerous locations. Cable trays broke loose and caused damage. The vessel continued in service without using the No. 1 cargo tank and the damage was repaired at a later date. (Harris 1993) 
Table 2-5. (continued).

Methane Princess, Voyage 182, May 30, 1971

Liquid nitrogen loading line relief valve opened and spilled liquid nitrogen through the combined vent line onto the foredeck. Some cracking in deck plating occurred. Relief valve had been imporperly reset at annual survey to a lower than specified pressure setting. ${ }^{\text {a }}$ (Harris 1993)

Waterbury, Vermont June 25, 1971

A truck had a tire blowout, hit some rocks by the road, punctured a hole in the tank and spilled $20 \%$.

There was no fire and the remainder of the load was dumped. (GAO 1978)

Warner, New Hampshire August 28, 1971

The driver of a truck drove off the road due to driver fatigue. The truck overturned, cracking fittings on the truck. There was a small gas leak, but no fire. (GAO 1978)

North Whitehall, Wisconsin October 8, 1971

An LNG transport truck was in a head-on collision with another truck. There was a gasoline and tire fire, but no loss of the LNG cargo. (GAO 1978)

Methane Progress, Voyage 193. October 31, 1971

A liquid nitrogen storage tank was inadvertently overfilled, causing discharge through the tank vent valve and combined vent line onto the foredeck. Main and second deck plating were cracked. (Frondeville 1977)

Raynham, Massachusetts October 19:73

An LNG truck sideswiped a parked car. 'The truck brakes locked and the trailer overturned. There was no LNG cargo on board and no fire occurred. (GAO 1978)

Junction of Interstates 80 and 95, Fort Lee, New Jersey 1973

A driver could not negotiate a turn off. The resulting rollover demolished the tractor and caused $\$ 40,000$ damage to the LNG trailer. No fire occurred. (GAO 1978)

Route 40, Hamilton Township, New Jersey February 18, 1974

Faulty brakes on a truck caused a wheel fire. A check valve cracked and $5 \%$ of the LNG load leaked out. The report is unclear whether the LNG ignited or not. (GAO 1978)

McKee City, New Jersey February 21, 1974

A loose valve on a truck leaked LNG during a transfer operation. (GAO 1978)

Massachusetts, July 16, 1974

A one-inch globe valve (nitrogen purge valve) was overpressured during cargo loading and spilled approximately 40 gallons of LNG. The sudden pressure rise occurred when the cargo loading valve closed because of a momentary electrical power interruption after generator switchover. The liquefied natural gas cracked the canopy deck. (GAO 1978)

Chatanooga, Tennessee January 1976

A transport truck carrying $L N G$ overturned due to an oil spill on an exit ramp. There was no fire. The truck was righted and continued delivery of its cargo. (GAO 1978) 
Table 2-5. (continued).

\section{Dalton, Georgia November 1975}

The driver of a transport truck carrying LNG swerved to avoid a pedestrian, hit a guard rail and rolled over and down an 80 -foot embankment. There was $\$ 18,000$ damage to the trailer, but apparently no fire. (GAO 1978)

\section{Pawtucket, Rhode Island September 16, 1976}

A car hit an LNG trailer at the landing wheels, caused the trailer to overturn. There was no LNG loss or fire. (GAC 1978)

\section{Connecticut Turnpike March or April 1977}

An LNG truck was parked at the side of the turnpike with a blowout when it was hit in the rear by a tow truck. There was no leak or fire. (GAO 1978)

\section{Arzew, Algeria March 30, 1977}

An LNG spill of $1500 \mathrm{~m}^{3}$ occurred at the Camel plant, attributed to the rupture of a aluminum-cast valve body on a transfer line during the night. A plant operator was frozen to death, and the contingency plan was put into action. The LNG cloud had dissipated at dawn without further casualty. (Frondeville 1977)

Waterbury, Connecticut July 1977

A "single wall" LNG trailer was hit in the rear by a tractor-trailer, knocking the axle off. In this case the controls were under the tank. There was no loss of cargo. (GAO 1978)

\section{El Paso Paul Kayser, June 29, 1979}

After taking avoiding action to prevent a collision in fog at $22: 30$ hours the $125,000 \mathrm{~m}^{3} \mathrm{Gaz}$ Transport membrane LNG carrier ran on to rocks and grounded in the Straits of Gibraltar when loaded with $95,500 \mathrm{~m}^{3}$ of LNG. The bottom shell and double bottom were extensively damaged over almost the full length of the cargo spaces. The invar membrane was indented but remained liquid-tight. There was no cargo spillage. The vessel was refloated on July 4 and on July 11 the transfer of the cargo of LNG to sister ship El Paso Sanatrach was completed. The damaged ship was then gas-freed, inerted and towed to Lisbon for temporary repairs. Later the vessel proceeded under her own power to the ships's original building yard at Dunkerque for full repair work. (Harris 1993)

\section{LNG Taurus, December 12, 1980}

The $126,750 \mathrm{~m}^{3}$ Moss spherical tank LNG carrier grounded in strong winds at Mutsure anchorage, near the end of a loaded voyage from Bontang, Indonesia to Tobata, Japan. Approximately $40 \%$ of the double bottom was breached and open to the sea. Severe weather conditions with gale force winds and $3 \mathrm{~m}$ waves around the vessel hampered the salvage operations. Fuel from the bunkers was transferred to a barge and the damaged ballast spaces were pressurized. The vessel was refloated on December 16 and then towed to Tobata where the full cargo of LNG was discharged on December 18. (Harris 1993)

Tenaga Satu, June 1983

Cargo pump defects caused damage to the No. 1 cargo tank on the $130,000 \mathrm{~m}^{3}$ Gaz Transport membrane LNG carrier. Approximately $110 \mathrm{~m}^{2}$ of the invar primary barrier was renewed and patches fitted at Yokohama, Japan in June 1984. (Harris 1993) 
Table 2-5. (continued).

Ramdane Abane, February 9, 1984

During the discharge of Algerian LNG at Montoir, France a cargo leak was noted through the No. 5 cargo tank membrane on the $126,190 \mathrm{~m}^{3} \mathrm{Gaz}$ Transport membrane LNG carrier. The vessel was taken to the roads for gas-freeing and inspection. Several suction manifolds were also found to be cracked. Repairs were later carried out at St. Nazaire, France. (Harris 1993)

Isabella, June 14, 1985

A cargo valve failed on the $35,491 \mathrm{~m}^{3}$ Gaz Transport membrane LNG cairier at the beginning of the LNG discharge at Barcelona, Spain after a voyage from Skikda, Algeria. LNG from the No. 1 cargo tank overflowed onto the main deck, causing severe cracking to the steelwork. The tank was discharged without further incident. Extensive repairs were required resulting from the spill. (Harris 1993)

Tellier, February 15, 1989

Moorings broke on the $40,081 \mathrm{~m}^{3}$ Technigaz membrane LNG carrier, due to $160 \mathrm{~km} / \mathrm{hr}$ winds, during LNG loading at Skikda, Algeria. Four terminal loading arms were damaged and LNG leaked to the main deck causing extensive damage to the steelwork and upper primary and secondary barriers in the No. 3 cargo tank. The vessel delivered LNG to Fos, France on February 16. Steelwork repairs were carried out at Marseilles and the ship returned to service in June with one of the five cargo tanks out of commission. Permanent repairs to the containment system were completed at Marseilles in October 1990. (Harris 1993)

a. This event does not involve $L N G$, but provides a representative failure scenario involving a cryogenic liquid.

in this table involve LNG tanker ships; they are included because: (a) some of the failure modes (e.g., overfilling, isolation valve failures, lightning strikes, high winds) appear to be generally relevant to a refueling station, and (b) they show that more often than not, the consequences of the accidents are limited in scope (e.g., some deck plate cracking).

Table 2-6. Nomenclature used in Figure 2-1.

\begin{tabular}{lll}
\hline Component ID & \multicolumn{1}{c}{ Component Type } & \multicolumn{1}{c}{ Notes } \\
\hline FCV-103 & Valve & Pump inlet \\
FCV-104 & Valve & Pump vent \\
FCV-105 & Valve & Recirculation \\
FCV-106 & Valve & Saturation coil feed \\
FCV-107 & Valve & Dispensing \\
V-1 & Valve & Top fill \\
V-2 & Valve & Hose drain \\
V-8 & Valve & Liquid phase \\
V-9 & Valve & Vapor phase \\
V-10 & Valve & LI-1 equalization \\
V-11 & Valve & Full trycock
\end{tabular}


Table 2-6. (continued).

\begin{tabular}{|c|c|c|}
\hline Component ID & Component Type & Notes \\
\hline $\mathrm{V}-12$ & Valve & Manual vent \\
\hline V-13 & Valve & Isolation pump inlet \\
\hline V-14 & Valve & Isolation pump vent \\
\hline$V-15$ & Valve & Saturation isolation \\
\hline V-16 & Valve & Saturation pressure \\
\hline$V-17$ & Valve & Manual vent pump sump \\
\hline V-18 & Valve & Dispensing drain \\
\hline V-19 & Valve & Vacuum gauge tube \\
\hline$V-20$ & Valve & Safety selector \\
\hline V-21 & Valve & Evacuation \\
\hline $\mathrm{V}-22$ & Valve & Stack drain \\
\hline V-23 & Valve & Auxiliary top fill \\
\hline$V-24$ & Valve & Transport return \\
\hline$V-25$ & Valve & Transport suction \\
\hline$V-26$ & Valve & N2 purge \\
\hline V-27 & Valve & Sample isolation \\
\hline V-28 & Valve & Sample vent \\
\hline V-29 & Valve & Sample purge \\
\hline V-30 & Valve & Top fill isolation \\
\hline V-31 & Valve & Vehicle fill isolation \\
\hline V-32 & Valve & PSV-101A test \\
\hline V-33 & Valve & PSV-101B test \\
\hline V-34 & Valve & PSV-105B test \\
\hline V-35 & Valve & PSV-105A test \\
\hline V-36 & Valve & PSV-104C test \\
\hline V-37 & Valve & PSV-104B test \\
\hline CV-1 & Check valve & Fill \\
\hline $\mathrm{CV}-2$ & Check valve & Saturation return \\
\hline CV -3 & Check valve & Discharge \\
\hline PSV-101A & Safety valve & Inner vessel \\
\hline PSV-101B & Safety valve & Inner vessel \\
\hline PSV-101C & Safety valve & Saturation pressure \\
\hline
\end{tabular}


Table 2-6. (continued).

\begin{tabular}{|c|c|c|}
\hline Component ID & Component Type & Notes \\
\hline PSV-102A & Safety valve & Pump sump \\
\hline PSV-102B & Safety valve & Dispense line \\
\hline PSV-103 & Safety valve & Transport suction line \\
\hline PSV-104A & Safety valve & Top fill line \\
\hline PSV-104B & Safety valve & Top fill line \\
\hline PSV-104C & Safety valve & Saturation return line \\
\hline PSV-104D & Safety valve & Saturation return line \\
\hline PSV-105A & Safety valve & Pump vent line \\
\hline PSV-105B & Safety valve & Pump feed line \\
\hline PSE-101A & Rupture disk & Inner vessel \\
\hline PSE-101B & Rupture disk & Inner vessel \\
\hline PSE-101C & Rupture disk & Outer vessel \\
\hline PSE-102 & Rupture disk & Pump sump \\
\hline E-101 & Saturation coil & - \\
\hline F-1 & Filter & Transfer line \\
\hline TC-1 & Vacuum probe & - \\
\hline PDI-101 & Liquid level indicator & - \\
\hline PDT-101 & Liquid level transmitter & - \\
\hline M-1 & Meter & - \\
\hline P-101 & Pump & - \\
\hline PI-101A & Pressure indicator & Inner vessel \\
\hline PI-101B & Pressure indicator & Saturation \\
\hline PI-102A & Pressure indicator & Pump Sump \\
\hline PI-102B & Pressure indicator & Dispenser \\
\hline PT-101A & Pressure transmitter & Inner vessel \\
\hline PT-101B & Pressure transmitter & Saturation \\
\hline TT-102 & Temperature sensor & - \\
\hline TH-1 & Transfer hose & - \\
\hline FC-1 & Connection & Top fill \\
\hline $\mathrm{FC}-2$ & Connection & Vehicle fill \\
\hline FC-3 & Connection & Transport return \\
\hline $\mathrm{FC}-4$ & Connection & Transport suction \\
\hline
\end{tabular}


Table 2-6. (continued).

Component ID

Component Type

Notes

C-1

Connection

Sample cylinder

C-2

Connection

Sample vent

C-3

Connection

Sample purge

C-4

Connection

Vehicle vent

C-5

Connection

N2 purge

Connection to vent stack

Vent to atmosphere 


\section{QUALITATIVE RISK ASSESSMENT}

\subsection{Introduction}

This section documents the results of a qualitative risk assessment performed for a generic LNG refueling station and summarizes the approach used to obtain these results. The objectives of this assessment are to:

- Identify accident scenarios relevant to a broad spectrum of stations

- Determine which of these scenarios may be significant risk contributors.

Potential risk significance is determined through qualitative assessments of scenario relative likelihood and consequences. The scenario consequences are expressed in terms of the following potential outcomes: a large LNG release, onsite ignition of a large LNG release, and a large LNG offsite release. The analysis does not directly address public and worker health consequence measures (e.g., severe injuries and fatalities). However, these can be directly related to the three outcomes identified, especially when a quantitative analysis is performed. The analysis also does not address offsite ignition, as this would require treatment of offsite features (e.g., traffic, industry, population) judged to be beyond the scope of this study.

It must be emphasized that the results of this qualitative risk assessment are relative. The potentially dominant scenarios identified are believed to be more risk significant than other scenarios studied. Thus, the study results should be helpful to station designers and operators. However, a quantitative analysis is needed to determine if the scenarios identified are risk significant in an absolute sense; such an analysis is needed when supporting policy decisions.

\subsection{Approach}

Serious accidents can often be viewed as the culmination of a sequence of failures involving humans, hardware, or both. Such a sequence consists of an initial fault, an "initiating event", followed by failures of safety barriers (either engineered or natural) that would otherwise limit the severity of the accident. For example, in the 1944 Cleveland tank accident, the initial storage tank failure was followed by the failure of the bund wall to perform its intended function. The subsequent ignition of the gas and the failure of the second storage tank can also be viewed as failures of safety barriers, even though an engineered mitigating system was not involved.

Given this view of accidents, it can be seen that event trees, which graphically depict the different possible sequences of safety barrier successes and failures following an initiating event, provide a natural means to model accident scenarios. Event trees were introduced to risk assessment in the landmark Reactor Safety Study (also known as WASH-1400) performed by the U.S. Nuclear Regulatory Commission (USNRC 1975). Since that study, event trees have been used in many risk assessment applications. A number of transportation risk assessment studies use event trees, e.g., (Rhoads 1978), as does a recent investigation of oil spill accidents (Siu et al. 1995).

An example event tree for scenarios initiated by an operator tank filling error is shown in Figure 3-1. The safety barriers challenged following the initiating event are listed at the top of the tree; these are called 

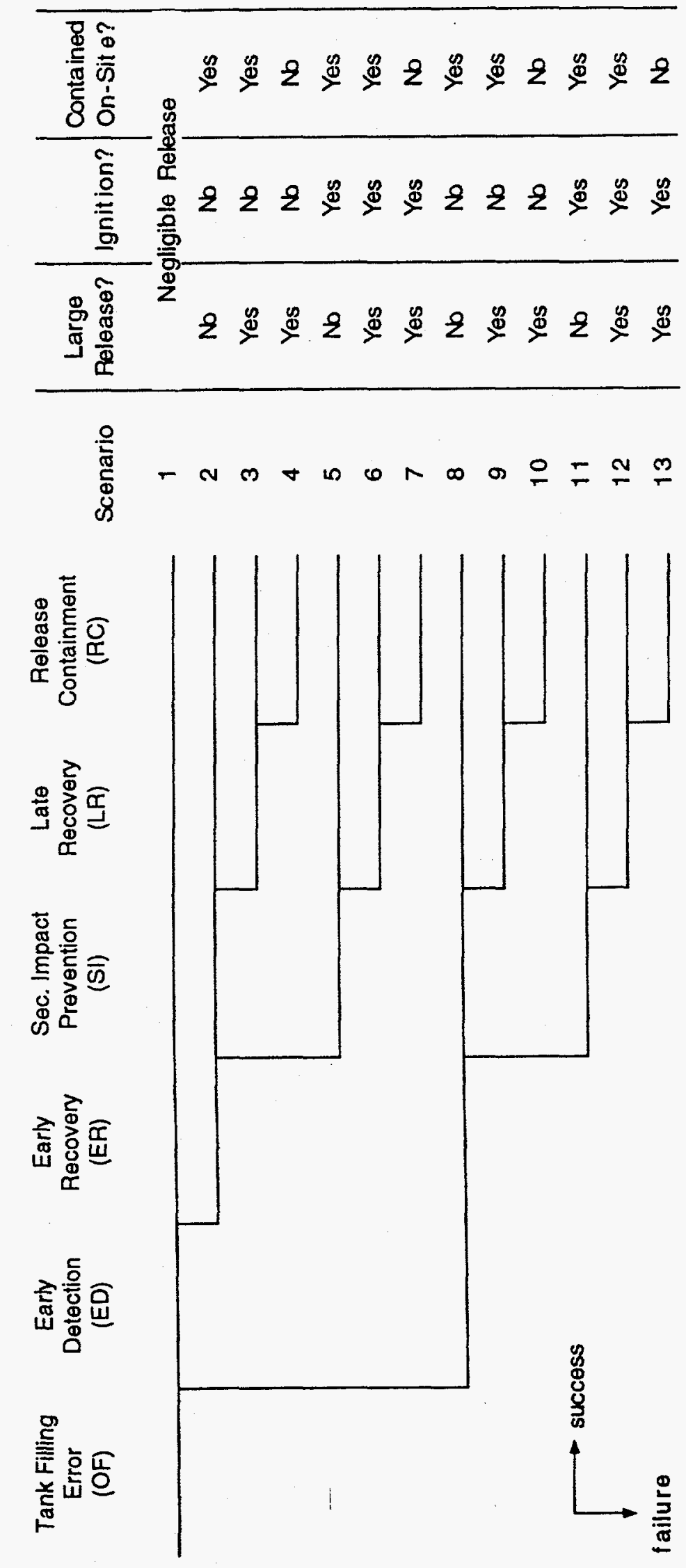

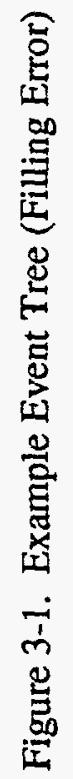


"top events". Each node in the tree represents a safety barrier challenge; the path leading to the right of the node represents success of the safety barrier, while the path leading down from the node represents failure.

Figure 3-1 shows that the event tree is an inductive diagram; it shows what happens after a given initiating event. Clearly, therefore, the qualitative risk assessment must include multiple event trees, each one corresponding to a different initiating event. Furthermore, efforts must be spent to ensure that the list of initiating events considered is reasonably complete. If an initiating event is not addressed, the analysis will not treat the risk contributions from scenarios associated with that initiating event. On the other hand, analysis resources can be exhausted if too many initiating events are treated. Practical risk assessment requires a balance between the desire for completeness and available resources.

With these issues in mind, the steps employed in this study to perform the qualitative risk assessment are as follows:

1. Develop list of initiating events
a. Identify candidate initiating events
b. Group initiating events

2. Develop event trees
a. Identify event tree "top events"
b. Identify dependencies between top events and initiating events
c. Develop accident scenarios

3. Analyze accident scenarios
a. Identify scenarios leading to severe consequences
b. Identify potentially dominant scenarios
c. Determine refueling station characteristics affecting likelihood of dominant scenarios.

\subsection{Initiating Event Identification}

\subsubsection{Candidate Initiating Events}

As in many studies and recommended in the Probabilistic Risk Assessment (PRA) Procedures Guide (ANS 1980), this study employs a variety of methods to identify candidate initiating events, i.e., initiating events that might be treated in the analysis. The principal method used is the Master Logic Diagram (MLD). Other methods used include Failure Modes and Effects Analysis (FMEA), event sequence and task analyses, operating experience review, and review of other relevant studies.

A MLD is a logic diagram which is used to deduce how a single top event can be caused by underlying events (ANS 1980). MLDs are similar to fault trees in that they are deductive in nature. They 
are different in that they do not generally show all of the conditions that must arise for the top event to occur. (In other words, they do not generally include "AND" gates.)

Figures 3-2 through 3-4 show the MLDs developed for this study. The top events, shown in Figures 3-2 and 3-3 respectively, are "Serious Onsite Injury and/or Fatality" and "Serious Offsite Injury and/or Fatality". All of the branches in the diagrams represent "OR" gates. For example, Figure 3-2 shows that a serious onsite injury and/or fatality can involve an acute injury or fatality or a chronic injury. An acute injury or fatality, in turn, can involve asphyxiation, trauma, thermal burns, or cryogenic burns. The triangles in the diagram represent transfers to another tree (Figure 3-4); the diamonds represent events that can be (but are not) further defined.

Both Figures 3-2 and 3-3 show that LNG releases are a major (if not sole) contributor to the top event. They both transfer to Figure 3-4, which identifies several potential failures (hardware, human, and external) that may lead to a release. It should be emphasized that these failures may lead to an LNG release; they do not necessarily guarantee the occurrence of the release. The additional failures that must occur before a release can happen are identified in the event tree analysis, discussed in Section 3.4 below. Note also that the failure events are defined generically. This allows the broad application of this study's results to different refueling stations.

To supplement the MLD analysis, an $\mathrm{FMEA}^{\circ}$ was performed on the system shown in Figure 2-1 (Facility Number 1). This FMEA is provided in Appendix A. It shows that there are a number of single point failures (primarily involving relief valves) which can lead to releases of LNG to the environment. Event sequence and task analyses (defining the sequence of actions taken during station and end user vehicle refueling), reviews of past events, and reviews of other studies were also performed to supplement the MLD.

Regarding other studies, Williamson and Edeskuty (1983) defined several hazards which involve or influence the occurrence of initiating events:

- Storage tank failures

- Unloading and transfer leaks

- Corrosion of dissimilar metals in systems and foreign material induced corrosion

- Collisions of transport vehicles

- Vaporization system failure

- $\quad$ Fires and explosions

- Gas-air vapor cloud dispersion

c. A Failure Modes and Effects Analysis (FMEA) is an inductive exercise which postulates the failure of every system component and determines the consequences of these failures. 


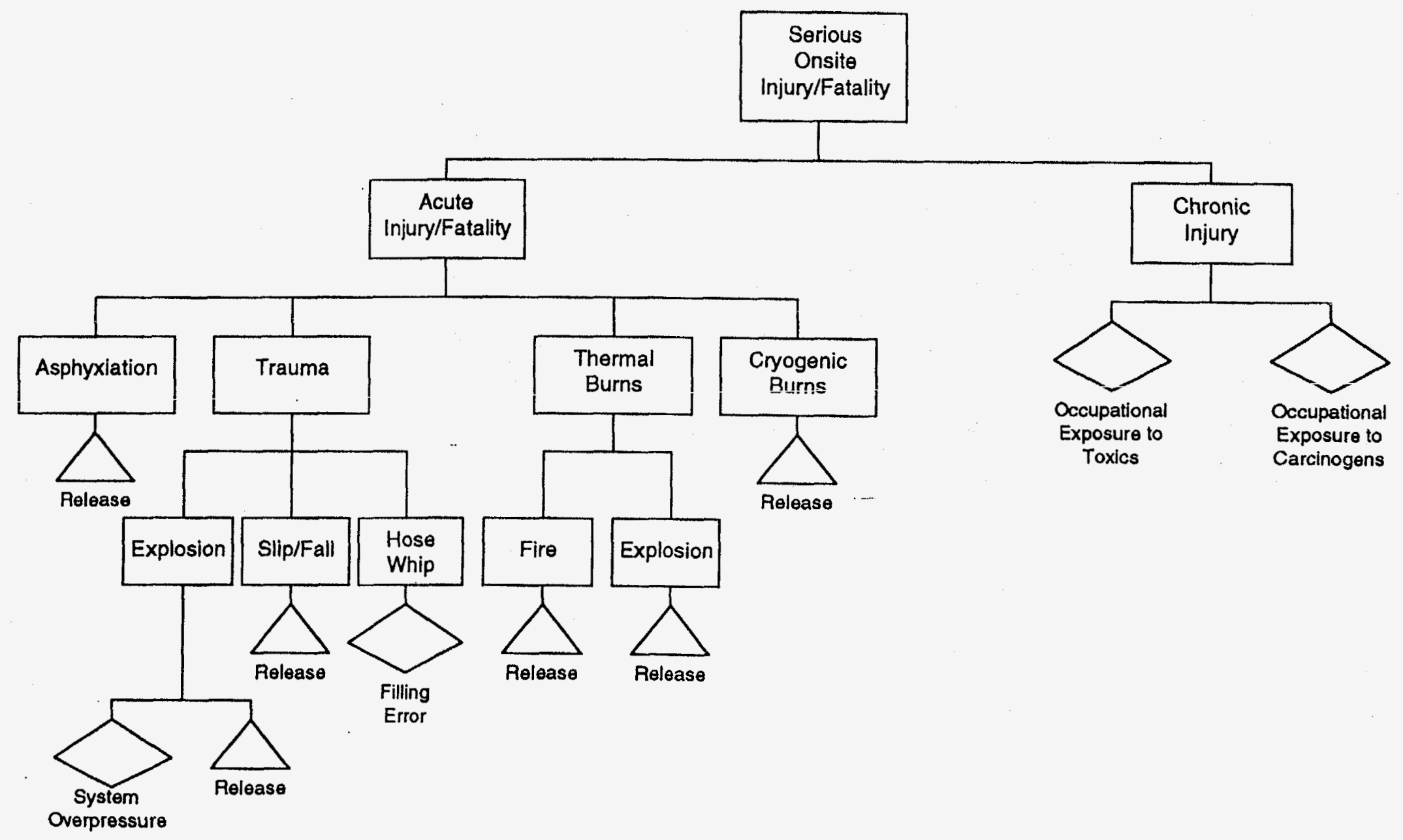

"Addresses only issues that might distinguish LNG from diesel fuel.

Figure 3-2. Master Logic Diagram: Onsite Serious Injury or Fatality 


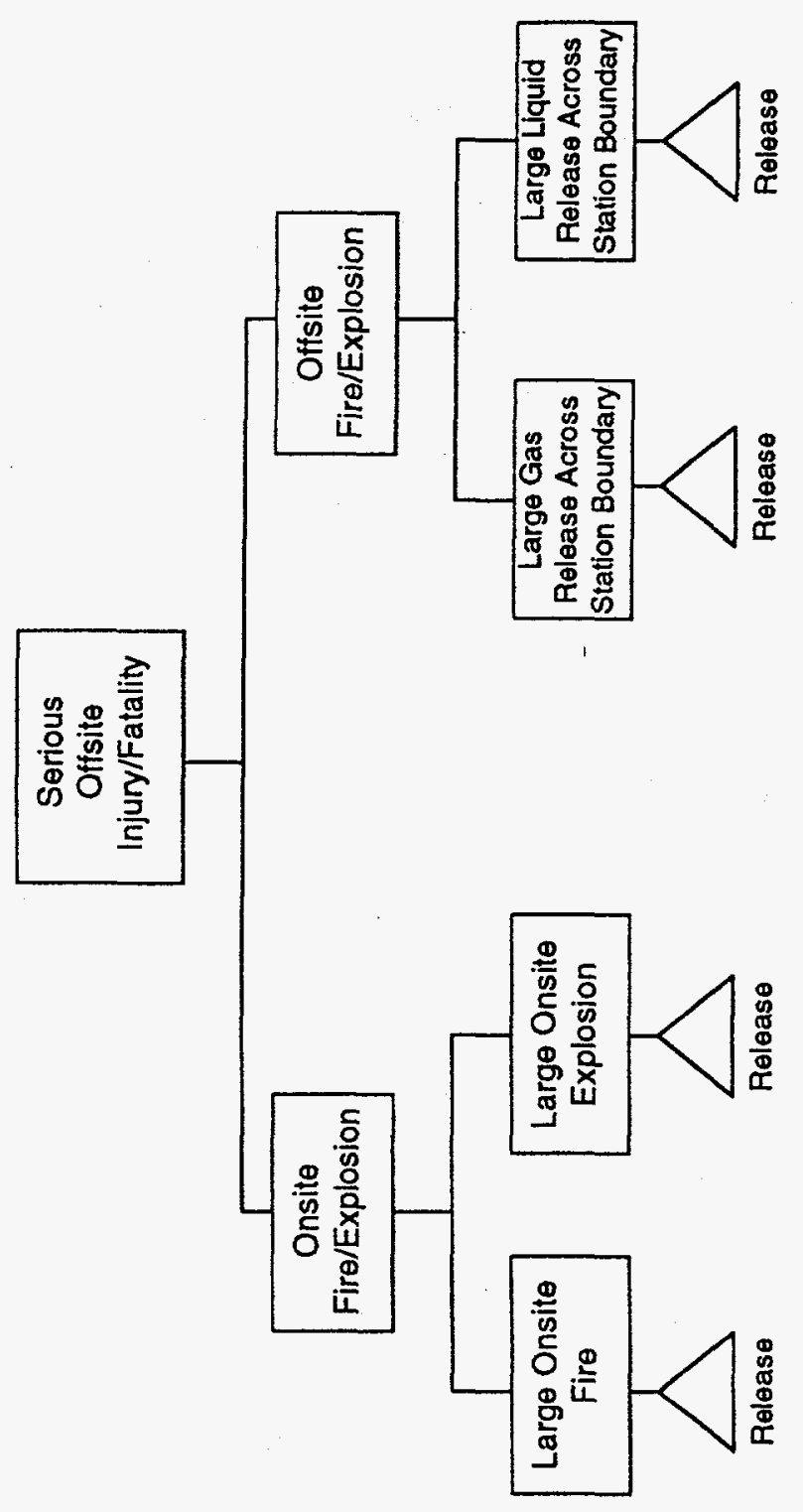

章 


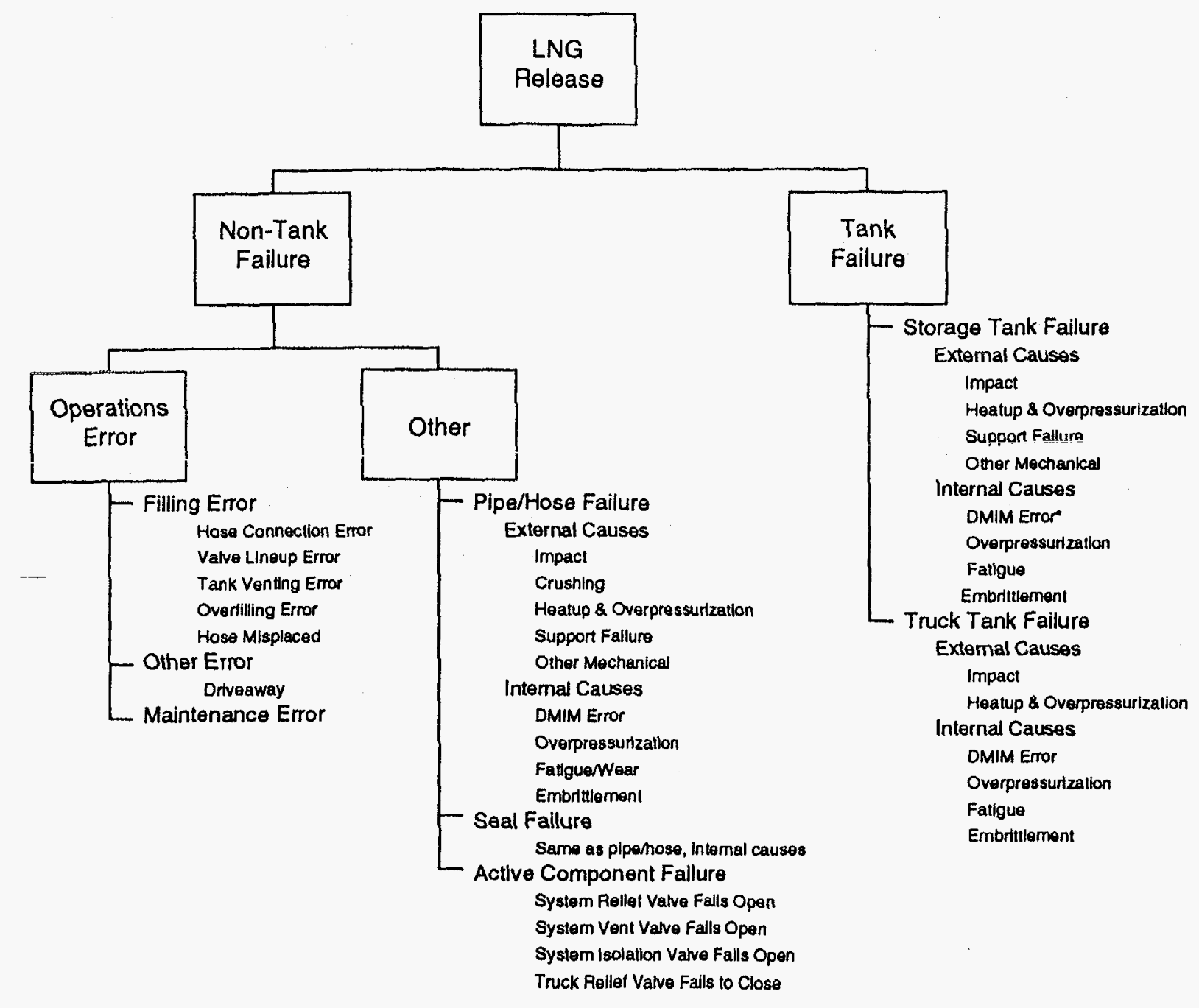

"DMIM = Design, Manufacturing, Installation, or Maintenance

Figure 3-4. Master Logic Diagram Continuation: LNG Release 
- Temperature extremes

- Personnel exposure (cryogenic temperatures and flames)

- Human factors

- Reactivity of cryogens.

Melchers and Feutrill (1995), in their report on an ongoing risk assessment on LPG-fueled vehicles, identify the following initiating event classes:

- Cold catastrophic failure of a tank (due to metal fatigue, corrosion, or overfilling)

- Flame impingement on a tank

- Impact by vehicles

- Negligent action by operators or drivers (driveaways, uncoupling hoses with valves open, etc.)

- Poor maintenance (unrepaired hose wear and tear, or valve spring corrosion, etc.)

- Vandalism and attempts at fuel theft.

Selected results of these other studies have been integrated into the LNG release MLD shown in Figure $3-4$ as appropriate.

\subsubsection{Initiating Event Grouping}

In order to keep the analysis tractable, the candidate initiating events shown in Figure 3-4 were grouped. (While two of the candidate events shown in Figure 3-2 (i.e., chronic injuries due to occupational exposures to toxins and carcinogens) are not included in Figure 3-4, these events are believed to be of lesser significance and are not further addressed in this study.) The groups were distinguished based on:

- Potential impact on the safety functions modeled in the event trees (see Figure 3-1 and Section 3.4)

- Potential impact on the likelihood of recovery efforts

- Potential magnitude of releases.

For example, all internal failure causes for the storage tank (i.e., design, manufacturing, installation, and maintenance errors; overpressurization; fatigue; embrittlement) are grouped together because the particular failure cause is not expected to affect the likelihood of recovery, ignition, containment, and so forth. Operator errors leading to release are grouped together because they imply the immediate presence of an operator during the event; this should increase the chances for recovery. Events potentially involving multiple tanks (e.g., driveaway accidents which could involve both the storage and vehicle tanks) are distinguished from other events because they can lead to larger releases of LNG. 
Table 3-1 lists the initiating events resulting from this grouping process and provides a map relating these initiating events to the candidate iritiating events (MLD failure causes) shown in Figure 3-4. Note that some of the candidate initiating events appear under more than one initiating event. This is because some of the failure causes (e.g., impact) can arise from different sources (e.g., tornadoes, vehicle crashes).

Table 3-1. Initiating events and mapping to MLD failure causes.

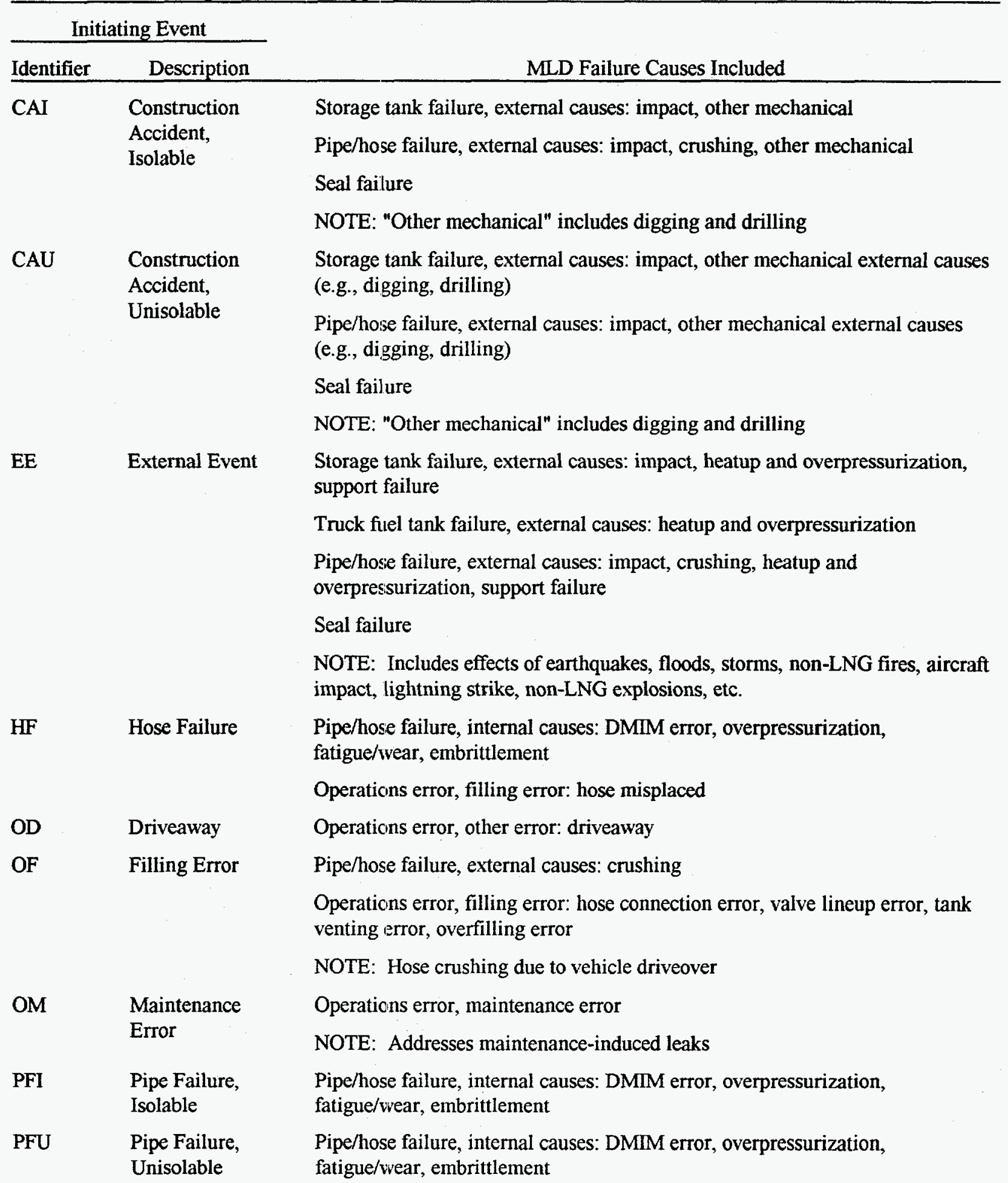


Table 3-1. (continued).

\begin{tabular}{|c|c|c|}
\hline \multicolumn{2}{|c|}{ Initiating Event } & \multirow[b]{2}{*}{ MLD Failure Causes Included } \\
\hline Identifier & Description & \\
\hline SFI & $\begin{array}{l}\text { Seal Failure, } \\
\text { Isolable }\end{array}$ & Seal failure: DMIM error, overpressurization, fatigue/wear, embrittlement \\
\hline SFU & $\begin{array}{l}\text { Seal Failure, } \\
\text { Unisolable }\end{array}$ & Seal failure: DMIM error, overpressurization, fatigue/wear, embrittlement \\
\hline \multirow[t]{2}{*}{ ST } & \multirow{2}{*}{$\begin{array}{l}\text { Storage Tank } \\
\text { Failure }\end{array}$} & Storage tank failure, external causes: support failure \\
\hline & & $\begin{array}{l}\text { Storage tank failure, internal causes: DMIM error, overpressurization, fatigue, } \\
\text { embrittlement }\end{array}$ \\
\hline \multirow[t]{2}{*}{ TTF } & \multirow[t]{2}{*}{$\begin{array}{l}\text { Truck Fuel } \\
\text { Tank Failure }\end{array}$} & $\begin{array}{l}\text { Truck tank failure, internal causes: DMIM error, overpressurization, fatigue, } \\
\text { embrittlement }\end{array}$ \\
\hline & & Active component failure: truck relief valve fails to close \\
\hline \multirow[t]{2}{*}{ TTT } & \multirow[t]{2}{*}{$\begin{array}{l}\text { Tanker Truck } \\
\text { Tank Failure }\end{array}$} & $\begin{array}{l}\text { Truck tank failure, internal causes: DMIM error, overpressurization, fatigue, } \\
\text { embrittlement }\end{array}$ \\
\hline & & Active component failure: truck relief valve fails to close \\
\hline \multirow[t]{3}{*}{ VA } & \multirow{3}{*}{$\begin{array}{l}\text { Vehicular } \\
\text { Accident }\end{array}$} & Storage tank failure, external causes: impact \\
\hline & & Truck tank failure, external causes: impact \\
\hline & & Pipe/hose failure, external causes: impact \\
\hline VFI & $\begin{array}{l}\text { Valve Failure, } \\
\text { Isolable }\end{array}$ & $\begin{array}{l}\text { Active component failure: relief valve fails open, vent valve fails open, isolation } \\
\text { valve fails to close }\end{array}$ \\
\hline VFU & $\begin{array}{l}\text { Valve Failure, } \\
\text { Unisolable }\end{array}$ & $\begin{array}{l}\text { Active component failure: relief valve fails open, vent valve fails open, isolation } \\
\text { valve fails to close }\end{array}$ \\
\hline
\end{tabular}

Appendix B presents fault trees for each of the initiating events as applied to a generic refueling station. Unlike an MLD, the fault trees identify all necessary and sufficient conditions for the occurrence of the top event.

\subsection{Event Trees}

\subsubsection{Safety Barrier Definitions}

An event tree, as discussed earlier, is a graphical representation of the possible scenarios that may follow an initiating event. The different scenarios are defined by successes and failures of safety barriers (called "top events" because of their placement in the event tree), both natural and engineered, that can prevent the initiating event from progressing to a major accident.

The top events considered in this study are adapted from those identified in a study on oil spill events (Siu et al. 1995). They are defined in terms of functions rather than engineered systems, in order to allow their application to a wide variety of facilities. They are also defined qualitatively, in keeping with the qualitative nature of this study. The top events are:

- Early Detection (ED): Detection of the release within a few minutes of its occurrence 
- $\quad$ Early Recovery (ER): Early (within a few minutes) termination of the release before most of the source inventory is lost

- Secondary Impact Prevention (SI): Prevention of ignition or other additional effects (e.g., large releases from additional sources)

- Late Recovery (LR): Late (several minutes or more) termination of the release before most of the source inventory is lost

- Release Containment (RC): Containment of the release in the vicinity of the release.

\subsubsection{Dependencies}

In order to develop the possible sequences following an initiating event, dependencies between the initiating event and the top events, as well as those between the different top events, must be identified.

Consider the event tree shown in Figure 3-5, which models the possible sequences following a release caused by a severe external event $(\mathrm{EE}){ }^{\mathrm{d}}$. It can be seen that the EE event tree has a number of branches labeled "GF"; this denotes a "guaranteed failure." This reflects the modeling assumption that an external event severe enough to directly cause a large LNG release is also severe enough to greatly inhibit recovery efforts. Other assumed effects of the different initiating events on the top events are documented in the initiating event-to-safety barrier dependency matrix shown in Table 3-2.

Figure 3-5 also shows that given failure of early detection (ED), early recovery (ER) is guaranteed to fail. This is an example of a top event-to-top event dependency. The full dependency matrix for top event interactions is shown in Table 3-3.

Both Tables 3-2 and 3-3 represent generic dependency relationships. It is possible that additional dependency relationships exist for particular facilities. For example, in situations where subsequent failures can lead to releases from additional tanks (top event SI), the combined inventories may be large enough to overwhelm existing berms, depending on the sizing of the berms. The characteristics of the three facilities visited with respect to the event tree top events are discussed in Section 3.5.

\subsubsection{Scenario Identification}

Using the relationships shown in Tables 3-2 and 3-3, event trees have been developed for each of the initiating events identified in Table 3-1. The full set of event trees is shown in Appendix C. Figures 3-1 and 3-5 show representative event trees for tank filling errors (OF) and external events (EE), respectively.

d. The "external events" (i.e., events involving faults external to the system) treated by this tree include natural phenomena (e.g., earthquakes, floods, windstorms, lightning) and non-LNG fires. A number of other external events (e.g., construction accidents) are treated using different event trees. 


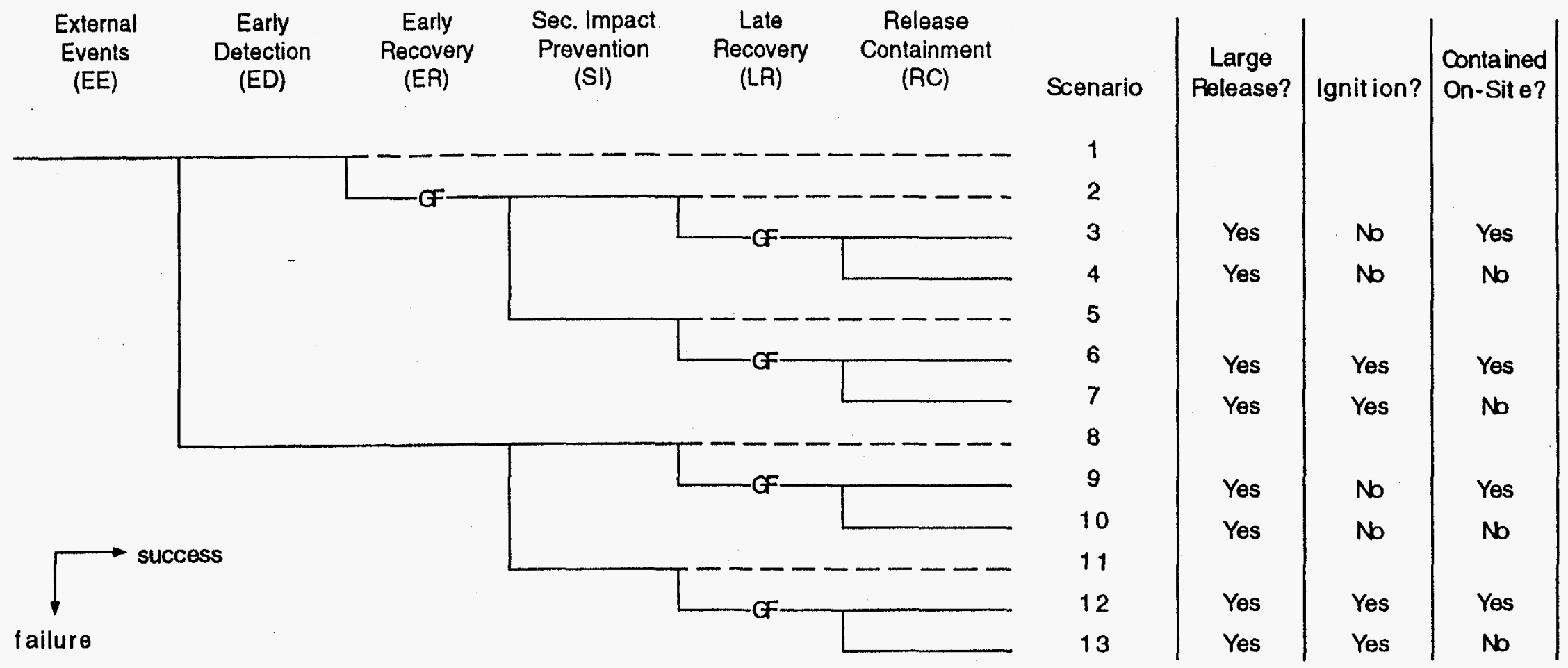

Figure 3-5. External Events Event Tree 
Table 3-2. Initiating event-to-top event dependency matrix.

Top Events

\begin{tabular}{|c|c|c|c|c|c|}
\hline $\mathrm{IE}^{\mathrm{a}}$ & ED & ER & SI & LR & $\mathbf{R C}$ \\
\hline CAI & GS & GF & (1) & - & - \\
\hline $\mathrm{CAU}$ & GS & GF & (1) & GF & - \\
\hline $\mathrm{EE}$ & $(2)$ & GF & (3) & GF & (4) \\
\hline $\mathrm{HF}$ & (5) & (6) & - & - & -- \\
\hline OD & GS & - & - & - & $(7)$ \\
\hline OF & (5) & (6) & - & - & - \\
\hline $\mathrm{OM}$ & (8) & - & (9) & - & - \\
\hline PFI & - & - & - & - & - \\
\hline PFU & - & GF & - & GF & - \\
\hline SFI & - & - & - & - & - \\
\hline SFU & - & GF & - & GF & - \\
\hline ST & - & GF & - & GF & - \\
\hline TTF & - & GF & - & GF & $(10)$ \\
\hline TTT & - & GF & - & $\mathrm{GF}$ & - \\
\hline VA & GS & GF & (11) & GF & - \\
\hline VFI & - & - & - & - & - \\
\hline VFU & - & $\mathrm{GF}$ & - & $\mathrm{GF}$ & - \\
\hline
\end{tabular}

a. Descriptions of the Initiating Events are in Table 3-1.

ED Early Detection: Detection of the release within a few minutes of its occurrence

ER Early Recovery: Early (within a few minutes) termination of the release before most of the source inventory is lost

SI Secondary Impact Prevention: Prevention of ignition or other additional effects (e.g., large releases from additional sources)

LR Late Recovery: Late (several minutes or more) termination of the release before most of the source inventory is lost

RC Release Containment: Containment of the release in the vicinity of the release

GS $=$ Guaranteed Success

$\mathrm{GF}=$ Guaranteed Failure

Other Notes:

1. Presence of construction activities increases likelihood of ignition sources.

2. Many external events can reduce the likelihood of early detection (e.g., due to loss of power, distraction).

3. Ignition sources are more likely for some external events (e.g., thunderstorms).

4. External events can decrease or increase likelihood of containment success. Examples: earthquake fails dike; storm disperses $L N G$ vapor.

5. Presence of personnel increases likelihood of early detection.

6. Presence of personnel increases likelihood of early recovery.

7. Truck release may be close to site boundary.

8. Time to detection depends on size and location (e.g., in yard or in confined space) of leak.

9. Presence of maintenance activities increases likelihood of ignition sources.

10. Containment success likely, given size of fuel tank. (Only containment problem arises if the release occurs near/at site boundary.)

11. Accident environment increases likelihood of ignition sources. 
Table 3-3. Top event-to-top event dependency matrix.

Top Events

\begin{tabular}{|c|c|c|c|c|c|}
\hline $\mathrm{IE}^{\mathrm{a}}$ & ED & ER & SI & LR & $\mathrm{RC}$ \\
\hline ED & - & (1) & - & - & - \\
\hline ER & - & - & (2) & (2) & (2) \\
\hline SI & - & - & - & - & - \\
\hline LR & - & - & - & - & (3) \\
\hline $\mathrm{RC}$ & - & - & - & - & \\
\hline
\end{tabular}

a. Descriptions of the Initiating Events are in Table 3-1.

ED Early Detection: Detection of the release within a few minutes of its occurrence

ER Early Recovery: Early (within a few minutes) termination of the release before most of the source inventory is lost

SI Secondary Impact Prevention: Prevention of ignition or other additional effects (e.g., large releases from additional sources)

LR Late Recovery: Late (several minutes or more) termination of the release before most of the source inventory is lost

RC Release Containment: Containment of the release in the vicinity of the release

GS $=$ Guaranteed Success

$\mathrm{GF}=$ Guaranteed Failure

Other Notes:

1. Failure of ED guarantees failure of ER.

2. Success of ER makes top event irrelevant

3. Success of LR makes top event irrelevant.

4. Top events appear in rough chronological order; only dependencies of later events on earlier events are modeled.

The accident scenarios for each initiating event follow directly from the event trees. For example, Scenario 3 of the EE event tree (Figure 3-5) involves the occurrence of the external event (EE), successful early detection ( $/ E D)$, guaranteed failure of early recovery $\left(E R^{\prime}\right)$, successful prevention of secondary impacts (/SI), guaranteed failure of late recovery (LR'), and successful containment of the release (/RC). The Boolean representation of this sequence of events is:

Scenario $3=\mathrm{EE}^{*} / \mathrm{ED}^{*} \mathrm{ER}^{\prime *} / \mathrm{SI}^{*} \mathrm{LR}^{\prime *} / \mathrm{RC}$

where the asterisk $\left({ }^{*}\right)$ denotes the logical AND operator, the slash (/) denotes success, no slash denotes failure, and the prime (') denotes a guaranteed event. 


\subsection{Scenario Analysis}

\subsubsection{Scenarios with Severe Consequences}

The event trees in Figures 3-1 and 3-5 show the assumed consequences of each accident scenario. A "large release" is one that poses a significant hazard to onsite and offsite personnel. Depending on the site characteristics, this is generally on the order of several hundreds of gallons. ${ }^{e}$ The other consequences are self-explanatory.

Appendix D provides lists of all of the scenarios leading to large releases, large releases ignited onsite, and large releases which go offsite. These lists have been constructed simply by collecting all of the relevant sequences from each event tree.

\subsubsection{Potentially Dominant Scenarios}

The numerous scenarios listed in Appendix D are not all equal contributors to risk. Two scenarios leading to the same undesired consequences (e.g., onsite ignition of a large release) will have different contributions if their likelihoods differ.

Tables 3-4 and 3-5 show the lists of high consequence scenarios believed to be the most risk significant in terms of onsite ignition (of a large release) and large offsite release, respectively. This list has been developed by employing pairwise qualitative comparisons of scenarios within each event tree. The comparisons generally take advantage of the observation that, generally speaking, failures (human or hardware) are far less likely than successes. ${ }^{f}$ Thus, the risk contribution from one scenario is usually assumed to dominate that from another if: a) both scenarios lead to the same consequences, and b) the first scenario involves fewer failure events than the second. For example, in comparing the first construction accident scenario (CAI) with the second (CAU), both lead to onsite ignition of a large release of LNG. However, the latter scenario (CAU) involves the failure of spill containment. From the standpoint of large release occurrences, therefore, the first scenario should dominate the latter.

Exceptions to this dominance assumption are as follows:

- $\quad$ For the external events (EE) scenarios, it is assumed that failure of early detection (ED) is more likely than success, due to the impact of the external event on facility hardware and operators.

- $\quad$ For the maintenance (OM) and isolable pipe (PFI), seal (SFI), and valve (VFI) failure scenarios, it cannot be determined if scenarios involving the success of early detection (/ED) and the failure of early recovery given an initiator (ER/IE) are significantly more likely than

e. Truck fuel tank releases, while generally involving smaller quantities, are modeled as being capable of leading to "large releases" because they can occur close to the site boundary.

f. This rule does not cover situations where failure is guaranteed because of previous occurrences during the scenario. 
Table 3-4. Potentially dominant scenarios: large LNG release and onsite ignition.

\begin{tabular}{|c|c|c|c|c|c|c|}
\hline \multicolumn{2}{|l|}{ IE } & \multicolumn{4}{|c|}{ Top Events } & Notes \\
\hline CAI & $/ D^{\prime}$ & ER' & SI & LR & /RC & For instance, collisions between construction equipment and refueling station components. \\
\hline CAU & $/ \mathrm{ED}^{\prime}$ & $\mathrm{ER}^{\prime}$ & SI & LR' $^{\prime}$ & /RC & For instance, collisions between construction equipment and refueling station components. \\
\hline $\mathrm{EE}$ & ED & $\mathrm{ER}^{\prime}$ & SI & $\mathbf{L R}^{\prime}$ & $/ \mathrm{RC}$ & Gasoline pipeline failures and ignition due to large flood in Houston; tank floating has been observed \\
\hline HF & $/ \mathrm{ED}$ & ER & SI & LR & /RC & Failure must occur during refueling to be significant \\
\hline OD & $/ E D^{\prime}$ & ER & SI & LR & /RC & Driveaways are relatively common; most (if not all) have only involved small spills \\
\hline OF & /ED & ER & SI & LR & /RC & Tank venting practices, shipboard overfilling events, and single point failures indicate scenario credibility \\
\hline OM & $/ \mathrm{ED}$ & ER & SI & LR & /RC & Localized explosion has been observed for LNG bus; no procedures; industry is learning \\
\hline OM & ED & ER' & SI & LR & /RC & Few or no procedures, no standardized approaches; industry is learning \\
\hline PFI & $/ \mathrm{ED}$ & ER & SI & LR & $/ \mathrm{RC}$ & Passive pipeline failures are relatively unlikely; no known major events \\
\hline PFI & ED & ER' & SI & LR & $/ \mathrm{RC}$ & Passive pipeline failures are relatively unlikely; no known major events \\
\hline PFU & /ED & $\mathrm{ER}^{\prime}$ & SI & LR' $^{\prime}$ & $/ \mathrm{RC}$ & Passive pipeline failures are relatively unlikely; no known major events \\
\hline SFI & $/ \mathrm{ED}$ & ER & SI & LR & $/ \mathrm{RC}$ & Given early detection, recovery is likely \\
\hline SFI & ED & $\mathrm{ER}^{\prime}$ & SI & LR & $/ \mathrm{RC}$ & Cove Point event involved seal failure, no early detection, migration of vapor, explosion \\
\hline SFU & $/ \mathrm{ED}$ & ER' & SI & LR' & /RC & Possibility depends on system design (isolability of seal leaks) \\
\hline ST & $/ \mathrm{ED}$ & ER' $^{\prime}$ & SI & LR' $^{\prime}$ & RC & Cleveland tank employed $3.5 \%$ nickel steel (not used anymore); expect dominance by DMI error \\
\hline TTF & /ED & ER' & SI & LR' $^{\prime}$ & $/ \mathrm{RC}^{\prime}$ & Expect dominance by relief valve failure \\
\hline TTT & $/ \mathrm{ED}$ & $\mathrm{ER}^{\prime}$ & SI & LR' $^{\prime}$ & $/ \mathrm{RC}$ & Expect dominance by relief valve failure \\
\hline VA & /ED' & ER' & SI & $L^{\prime}$ & $/ \mathrm{RC}$ & Must be severe enough to fail pressure boundary; no LNG truck events reviewed have involved LNG fire \\
\hline VFI & $/ \mathrm{ED}$ & ER & SI & LR & /RC & Designs allow single-point failures by relief and vent valves \\
\hline VFI & ED & ER' & SI & LR & /RC & Designs allow single-point failures by relief and vent valves \\
\hline VFU & /ED & ER' & SI & LR' $^{\prime}$ & /RC & Possibility depends on system design (isolability of valve) \\
\hline \multicolumn{7}{|c|}{ a. descriptions of the Initiating Events are in Table 3-1. } \\
\hline ED & \multicolumn{6}{|c|}{ Early Detection: Detection of the release within a few minutes of its occurrence } \\
\hline ER & \multicolumn{6}{|c|}{ Early Recovery: Early (within a few minutes) termination of the release before most of the source inventory is lost } \\
\hline SI & \multicolumn{6}{|c|}{ Secondary Impact Prevention: Prevention of ignition or other additional effects (e.g., large releases from additional sources) } \\
\hline LR & \multicolumn{6}{|c|}{ Late Recovery: Late (several minutes or more) termination of the release before most of the source inventory is lost } \\
\hline $\mathrm{RC}$ & \multicolumn{6}{|c|}{ Release Containment: Containment of the release in the vicinity of the release } \\
\hline Notes: & \multirow{3}{*}{\multicolumn{6}{|c|}{$\begin{array}{l}\text { Slash (/) indicates success; no slash indicates failure. Prime (') indicates success/failure guaranteed. } \\
\text { Shaded scenarios appear to be of lesser concern on a generic basis.. }\end{array}$}} \\
\hline (1) & & & & & & \\
\hline (2) & & & & & & \\
\hline
\end{tabular}


Table 3-5. Potentially dominant scenarios: large LNG release offsite.

\begin{tabular}{|c|c|c|c|c|c|c|}
\hline \multirow{2}{*}{$\frac{\mathrm{IE}}{\mathrm{CAI}}$} & \multicolumn{5}{|c|}{ Top Events } & \multirow[b]{2}{*}{ Verv large and ranid releace reauired } \\
\hline & $/ \mathrm{ED}^{\prime}$ & ER' $^{\prime}$ & /SI & LR & $\mathrm{RC}$ & \\
\hline $\mathrm{CAU}$ & $/ E D^{\prime}$ & ER' & /SI & LR' $^{\prime}$ & $\mathrm{RC}$ & Very large and rapid release required \\
\hline $\mathrm{EE}$ & ED & ER' $^{\prime}$ & /SI & $\mathbf{L R}^{\prime}$ & $\mathrm{RC}$ & Includes damage to component due to flood, tornado, hurricane, lightning, etc. \\
\hline $\mathrm{HF}$ & $/ E D$ & ER & /SI & LR & $\mathrm{RC}$ & Very large release required; failure must occur during refueling to be significant \\
\hline OD & $/ D^{\prime}$ & ER & /SI & LR & $\mathrm{RC}$ & Driveaways are relatively common; most (if not all) have only involved small spills \\
\hline OF & $/ \mathrm{ED}$ & ER & /SI & LR & $\mathrm{RC}$ & Tank venting practices, shipboard overfilling events, and single point failures indicate scenario credibility \\
\hline OM & /ED & ER & /SI & LR & $\mathrm{RC}$ & Event appears possible \\
\hline OM & ED & ER' & /SI & LR & $\mathrm{RC}$ & Early detection of major leak likely \\
\hline PFI & /ED & ER & iSI & LR & $\mathrm{RC}$ & Very large and rapid release required; passive pipeline failures relatively unlikely; no known major events \\
\hline PFI & ED & $\mathrm{ER}^{\prime}$ & /SI & LR & $\mathrm{RC}$ & Very large and rapid release required; passive pipeline failures relatively unlikely; no known major events \\
\hline PFU & $/ \mathrm{ED}$ & ER' & /SI & $\mathbf{L R}^{\prime}$ & $\mathrm{RC}$ & Very large and rapid release required; passive pipeline failures relatively unlikely; no known major events \\
\hline SFI & $/$ ED & ER & /SI & LR & $\mathrm{RC}$ & Very large and rapid release required; possibility is site-specific \\
\hline SFI & $\mathrm{ED}$ & ER' & /SI & LR & $\mathrm{RC}$ & Very large and rapid release required; possibility is site-specific \\
\hline SFU & $/ E D$ & $\mathrm{ER}^{\prime}$ & /SI & $\mathbf{L R}^{\prime}$ & $\mathrm{RC}$ & Very large and rapid release required; possibility is site-specific \\
\hline ST & /ED & $\mathrm{ER}^{\prime}$ & /SI & LR' $^{\prime}$ & $\mathrm{RC}$ & Cleveland tank employed 3.5\% nickel steel (not used anymore); expect dominance by DMI error \\
\hline TTT & /ED & ER' & /SI & $\mathbf{L R}^{\prime}$ & $\mathrm{RC}$ & Expect dominance by DMI error \\
\hline VA & $/$ ED' $^{\prime}$ & ER' $^{\prime}$ & /SI & $\mathrm{LR}^{\prime}$ & $\mathrm{RC}$ & Must be severe enough to fail pressure boundary; no LNG truck events reviewed have involved LNG fire \\
\hline VFI & $/ \mathrm{ED}$ & ER & /SI & LR & $\mathrm{RC}$ & Very large and rapid release required \\
\hline VFI & ED & ER' $^{\prime}$ & /SI & LR & $\mathrm{RC}$ & Very large and rapid release required \\
\hline VFU & /ED & ER' & /SI & LR' & $\mathrm{RC}$ & Possibility depends on system design (isolability of valve) \\
\hline \multicolumn{7}{|c|}{ a. Descriptions of the Initiating Events are in Table 3-1. } \\
\hline ED & \multicolumn{6}{|c|}{ Early Detection: Detection of the release within a few minutes of its occurrence } \\
\hline ER & \multicolumn{6}{|c|}{ Early Recovery: Early (within a few minutes) termination of the release before most of the source inventory is lost } \\
\hline SI & \multicolumn{6}{|c|}{ Secondary Impact Prevention: Prevention of ignition or other additional effects (e.g., large releases from additional sources) } \\
\hline LR & \multirow{2}{*}{\multicolumn{6}{|c|}{ Late Recovery: Late (several minutes or more) termination of the release before most of the source inventory is lost }} \\
\hline $\mathrm{RC}$ & \multirow{2}{*}{\multicolumn{6}{|c|}{ Release Containment: Containment of the release in the vicinity of the release }} \\
\hline Notes: & & & & & & \\
\hline & \multirow{2}{*}{\multicolumn{6}{|c|}{$\begin{array}{l}\text { Slash }(/) \text { indicates success; no slash indicates failure. Prime (') indicates success/failure guaranteed. } \\
\text { Shaded scenarios appear to be of lesser concern on a generic basis. }\end{array}$}} \\
\hline & & & & & & \\
\hline
\end{tabular}


scenarios involving the failure of early detection (ED) and the consequent guaranteed failure of early recovery given an initiator (ER'|IE). In other words, it is not clear if

Probability $\{$ ED*ER|IE $\}>>$ Probability $\left\{E^{*} D^{*}||[E\}\right.$

where Probability $\{\mathrm{A} \mid \mathrm{B}\}$ denotes the conditional probability of event A given event B and "IE" refers to the initiating event.

Tables 3-4 and 3-5 also provide a preliminary comparison of scenarios for different initiating events. Shaded scenarios in the table are believed to be generally less likely than unshaded scenarios; the bases for the scenario classifications are provided in the notes column of the table. Note that the storage tank scenarios (which involve internal failure causes-see Table 3-1) are not shaded. Although catastrophic failures are believed to be very unlikely given current design and construction practices, the potential consequences are believed to be large enough to warrant their inclusion in the group of more important scenarios.

\subsubsection{Station Characteristics Affecting Dominant Scenarios}

Table 3-6 identifies a number of site-specific characteristics for each of the facilities visited relevant to the likelihood of the initiating events considered in this study. Table 3-7 lists those characteristics relevant to the success or failure of the event tree top events (i.e., the safety barriers). Comparing these characteristics with the potentially dominant scenarios listed in Tables 3-4 and 3-5, it can be seen that differences in design, operations, and siting might imply significant differences in risk.

For example, regarding station design, Facility Number 3 has an onsite vehicle maintenance shop whereas the vehicle maintenance shops for Facilities 1 and 2 are a few minutes away. When looking specifically at refueling station risk, therefore, Facility Number 3 is likely to have a higher risk contribution from maintenance activities than the other two facilities. This potentially higher contribution could come from a higher frequency of maintenance-induced releases (initiating event $\mathrm{OM}$ ) as well as an increased number of potential ignition sources (which affects the likelihood of top event SI). As another example, Facility Number 2 does not have a bund fully surrounding the main LNG storage tank (a trailer tank); while the tank is in a slight pit, it is not clear that, in the event of a full spill, the LNG will be fully contained. This reduces the likelihood of success of top event RC.

Differences in operation also are expected to have impacts on the station risk. Some potentially important factors include the frequency of refueling activities (Facility Number 3 is by far the busiest), the degree of public access to the refueling area (Facility Number 2 is open to the public - the site has a gasoline service station and convenience store; Facilities 1 and 3 are restricted access), the training of personnel in fueling vehicles (Facility Number 3 uses specially trained refueling technicians; refueling at Facility Number 2 is performed by the truck drivers, some of whom excessively vent their fuel tanks to speed up the process), the location of designated emergency response personnel (depending on the time of day, key staff for Facility Number 2 can be 20 to 30 minutes away from the station when an alarm sounds), and the trained response of all personnel to emergencies (Facility Number 2 allows drivers one override of the emergency shutdown system). These factors affect the frequency of operator errors (initiating events OD and OF) and the likelihood of recovery and accident mitigation (top events ER, LR, and SI).

Finally, differences in siting may also have a significant impact on station risk. These differences can affect the likelihood of release due to external events (e.g., earthquakes, fires, explosions, floods, 
Table 3-6. Noteworthy site-specific features affecting initiating event occurrence.

Factors Affecting Initiating Event Frequency

\begin{tabular}{|c|c|c|c|c|}
\hline IE & Causes Include & Facility Number 1 & Facility Number 2 & Facility Number 3 \\
\hline $\begin{array}{l}\text { CAI, } \\
\text { CAU }\end{array}$ & $\begin{array}{l}\text { Digging, drilling, } \\
\text { falling objects, other } \\
\text { impact }\end{array}$ & $\begin{array}{l}\text { System is aboveground. Low } \\
\text { activity in immediate area. }\end{array}$ & $\begin{array}{l}\text { System is aboveground or in } \\
\text { concrete-lined open trenches } \\
\text { covered by steel grates. Low } \\
\text { activity in immediate area. }\end{array}$ & System is aboveground or in open, concrete-lined pit. \\
\hline $\mathrm{EE}$ & $\begin{array}{l}\text { Earthquake, flood, } \\
\text { storm, fire (non- } \\
\text { LNG), aircraft }\end{array}$ & $\begin{array}{l}\text { Out of flood zone; desert } \\
\text { siting. Low potential for local } \\
\text { fires (low traffic, no fixed } \\
\text { combustibles). Range fires } \\
\text { have occurred in area. Well } \\
\text { away from regular flightpaths. }\end{array}$ & $\begin{array}{l}\text { Out of flood zone. Low } \\
\text { traffic area. Airport is about } \\
15 \text { miles away. }\end{array}$ & $\begin{array}{l}\text { Elevated about } 20 \text { feet above adjacent river. Urban location } \\
\text { provides potential missiles during storms. Adjacent railyards a } \\
\text { potential source of fire. Airport is about } 5 \text { miles away. }\end{array}$ \\
\hline $\mathrm{HF}$ & $\begin{array}{l}\text { Internal causes, } \\
\text { DMIM }^{\mathrm{b}} \text { error }\end{array}$ & $\begin{array}{l}\text { Hose is stainless steel bellows } \\
\text { with braided metal outer } \\
\text { sheath. Facility has been } \\
\text { operating for about } 1.5 \text { years. }\end{array}$ & $\begin{array}{l}\text { Hose is stainless steel } \\
\text { bellows with coiled plastic } \\
\text { outer sheath. Facility has } \\
\text { been operating for about } \\
1 \text { year. }\end{array}$ & $\begin{array}{l}\text { Hose is stainless steel bellows with braided metal outer sheath. } \\
\text { Facility has been operating for about } 3 \text { years. }\end{array}$ \\
\hline OD & Driveaway Error & $\begin{array}{l}\text { Low number of refueling } \\
\text { events per day. No driveaways } \\
\text { reported. Storage tank and } \\
\text { vehicle tank isolation provided } \\
\text { by nozzle design, check valves. }\end{array}$ & $\begin{array}{l}\text { No driveaways reported. } \\
\text { Storage tank and vehicle } \\
\text { tank isolation provided by } \\
\text { nozzle design, check valves. }\end{array}$ & $\begin{array}{l}\text { Driveaways occur about once per month. Storage tank and } \\
\text { vehicle tank isolation provided by nozzle design, check valves. }\end{array}$ \\
\hline $\mathrm{OF}$ & $\begin{array}{l}\text { Hose connection } \\
\text { error, valve lineup } \\
\text { error, tank venting } \\
\text { error, overfilling } \\
\text { error, hose misplaced }\end{array}$ & $\begin{array}{l}\text { Operator does not normally } \\
\text { vent vehicle tank. One } \\
\text { interlock: ground must be } \\
\text { attached to actuate pump and } \\
\text { allow LNG flow to vehicle. } \\
\text { Hose can be left on ground. }\end{array}$ & $\begin{array}{l}\text { Valve lineup controlled by } \\
\text { computer. Vehicle and } \\
\text { storage tanks often vented. } \\
\text { Interlock to detect correct } \\
\text { nozzle return. Training of } \\
\text { driver-fuelers variable. }\end{array}$ & $\begin{array}{l}\text { Valve lineup controlled by computer. Venting not often } \\
\text { necessary (high vehicle usage). Can leave hose on ground or } \\
\text { over bund. Designated refueling technician. }\end{array}$ \\
\hline $\mathrm{OM}$ & Maintenance error & $\begin{array}{l}\text { Vehicle maintenance area well } \\
\text { separated from fueling area. }\end{array}$ & $\begin{array}{l}\text { Vehicle maintenance shop a } \\
\text { few minutes away from } \\
\text { fueling area. }\end{array}$ & LNG maintenance performed in onsite diesel bus shop. \\
\hline $\begin{array}{l}\text { PFI, } \\
\text { PFU }\end{array}$ & $\begin{array}{l}\text { Overpressure, } \\
\text { internal causes, } \\
\text { DMIM }{ }^{\mathrm{b}} \text { error }\end{array}$ & $\begin{array}{l}\text { Low number of refuelings per } \\
\text { day. Facility has been } \\
\text { operating for about } 1.5 \text { years. }\end{array}$ & $\begin{array}{l}\text { Low number of refuelings } \\
\text { per day. Facility has been } \\
\text { operating for about } 1 \text { year. }\end{array}$ & $\begin{array}{l}\text { Equipment is in constant use } 16 \text { hours a day. Facility has been } \\
\text { operating for about } 3 \text { years. }\end{array}$ \\
\hline
\end{tabular}


Table 3-6. (continued)

Factors Affecting Initiating Event Frequency

IE Causes Include

SFI, Overpressure,

SFU material failure, DMIM $^{b}$ error

ST Overpressure, internal causes, $\mathrm{DMMM}^{\mathrm{b}}$ error

TTF Overpressure, internal causes, $\mathrm{DMIM}^{\mathrm{b}}$ error

TTT Overpressure, internal causes, DMIM $^{b}$ error

VA Vehicle accident

VFI, Relief valve, vent

VFU valve, isolation valve fails open

a. Table does not always comment on features common to all facilities visited. b. DMIM Error = Design, manufacturing, installation, or maintenance error Construction Accident, Isolable

$\mathrm{CAU}$ Construction Accident, Unisolable

EE External Event

HF Hose Failure

OD Driveaway

OF Filling Error

Initiating Event Abbreviations are further described in Table 3-1. about 1.5 years. side (near CNG facility)
Facility Number 2

Facility Number 3

Facility has been operating for Some problems with valve stem seals. Facility has been fitting. Facility has been operating for about 3 years. operating for about 1 year.

Facility has been operating for

Facility has been operating

for about 1 year.

Facility has been operating for about 3 years.

-

Weekly deliveries.

Several deliveries a week (almost once per day).

Low traffic. Sheet metal bund Concrete bund wall on wall. Concrete blocks on one 3 †sides.

$-$

Maintenance Error

Pipe Failure, Isolable

Pipe Failure, Unisolable

Seal Failure, Isolable

Seal Failure, Unisolable

Storage Tank Failure
Surrounded by concrete bund wall. Private vehicles not allowed in area. Adjacent elevated highway a possible hazard.

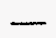


Table 3-7. Noteworthy site-specific features affecting top events.

Factors Affecting Top Event Success Likelihood

\begin{tabular}{|c|c|c|c|c|}
\hline $\begin{array}{c}\text { Top } \\
\text { Event } \\
\end{array}$ & Description & Facility Number 1 & Facility Number 2 & Facility Number 3 \\
\hline ED & Early detection & $\begin{array}{l}\text { Methane detectors located around } \\
\text { storage tank. Two level local } \\
\text { alarm; personnel must call site Fire } \\
\text { Department. }\end{array}$ & $\begin{array}{l}\text { Methane detectors in cabinets, } \\
\text { trenches, within bund. }\end{array}$ & $\begin{array}{l}\text { Methane detectors within bund } \\
\text { (near tank equipment and at } \\
\text { pump), under awning. }\end{array}$ \\
\hline ER & Early recovery & $\begin{array}{l}\text { Other than driver/refueler, few } \\
\text { personnel may be nearby. Manual } \\
\text { emergency shuitdowini locâted } \\
\text { nearby. }\end{array}$ & $\begin{array}{l}\text { Drivers and convenience store } \\
\text { personnel nearby. Shutdown } \\
\text { triggered manually or by } \\
\text { detectors. Flashing red light } \\
\text { alarm. Responsible staff may } \\
\text { be onsite or at the shop (a few } \\
\text { minutes away). }\end{array}$ & $\begin{array}{l}\text { Dedicated refueling technicians, } \\
\text { other staff available about } 16 \\
\text { hours/day. }\end{array}$ \\
\hline SI & $\begin{array}{l}\text { Secondary impact } \\
\text { (additional releases } \\
\text { or ignition) } \\
\text { prevention }\end{array}$ & $\begin{array}{l}\text { No additional major storage tanks. } \\
\text { Remote location and low traffic } \\
\text { reduce likelihood of ignition }\end{array}$ & $\begin{array}{l}\text { Site has truck trailer tank as } \\
\text { well as permanent fuel storage } \\
\text { tank. Low traffic and semi- } \\
\text { rural location. }\end{array}$ & $\begin{array}{l}\text { Three storage tanks. Urban } \\
\text { location, heavy traffic increase } \\
\text { number of potential ignition } \\
\text { sources. }\end{array}$ \\
\hline LR & Late recovery & $\begin{array}{l}\text { Site Fire Department trained to } \\
\text { deal with LNG fires; located } \\
\text { nearby and can respond in } \\
\text { minutes. Municipal Fire } \\
\text { Department also trained. }\end{array}$ & $\begin{array}{l}\text { Alarm sent to remote (out of } \\
\text { state) control center, which } \\
\text { notifies responsible staff. Staff } \\
\text { may be } 20-30 \text { minutes away. }\end{array}$ & $\begin{array}{l}\text { Prinary response provided by } \\
\text { station staff. Local Fire } \\
\text { Department is also trained. }\end{array}$ \\
\hline $\mathbf{R C}$ & $\begin{array}{l}\text { Release } \\
\text { containment }\end{array}$ & $\begin{array}{l}\text { Sheet metal bund wall surrounds } \\
\text { storage tank. }\end{array}$ & $\begin{array}{l}\text { Tanks are in shallow pit. } \\
\text { Relatively low concrete bund } \\
\text { wall only on } 3 \text { sides. }\end{array}$ & $\begin{array}{l}\text { Surrounded by } 5 \text {-foot high } \\
\text { concrete bund wall. }\end{array}$ \\
\hline
\end{tabular}


windstorms, lightning strikes, aircraft impacts), the likelihood of ignition given a release, and the public health and safety consequences of an accident. For example, the urban location of Facility Number 3 increases the availability of debris that may be driven by a severe storm. It also increases the availability of potential ignition sources and increases the number of people potentially exposed to the consequences of a major accident.

It should be cautioned that, as noted at the beginning of this section, these insights are relative. Additional, quantitative analysis is needed to determine if the factors identified above have a significant impact on absolute risk. 


\section{PHENOMENOLOGY OF LIQUEFIED NATURAL GAS}

\subsection{Introduction}

The handling of liquefied natural gas in a refueling station has several aspects common to present day fuels such as gasoline or diesel. With LNG, as well as with gasoline and diesel, all fuel transfers from the storage tank to the vehicle tank are carried out in liquid form. There is some vapor present during the transfer of gasoline and diesel, but the amount is very small and usually ignored. During the transfer of LNG from the storage tank to the vehicle tank, however, there is a need to collapse pressurized vapors in the ullage of the vehicle tank through the addition of colder liquid methane. If the vapors cannot be collapsed, then they must be safely vented. Also, vapors formed during the cooling of the transfer hose and nozzle must be recondensed or safely vented. Thus an LNG station is characterized by closed piping systems and dedicated vent stack to a greater extent than is the case for gasoline and diesel where the underground tanks have elevated vent stacks.

The principal hazard addressed in this report is the accidental combustion of the fuel. All fuels require vaporization as part of the combustion process. All fuels require that the mixtures of air and fuell vapor be within certain flammability limits in order that combustion can be sustained. All liquid fuels will disperse on the ground or water surface if spilled and all liquid fuels require an input of heat for vaporization.

Liquefied natural gas differs in several important ways from the more common liquid fuels, however. Because it is a liquid at $112^{\circ} \mathrm{K}$ at atmospheric pressure, the LNG must be insulated from external sources of heat. If spilled, the liquefied natural gas draws heat from the ground or water, from the air and from solar insolation. The rate of vaporization is dependent on the heat available from the surroundings and on heat transfer rate from those surroundings.

This section discusses the properties and behavior of LNG under nominal and accident conditions. (A qualitative comparison of LNG, gasoline, and diesel properties is provided in Table 4-1.) The section also addresses safety issues recently raised by Hunt (1996).

\subsection{Properties of Liquefied Natural Gas}

\subsubsection{Physical Properties}

The properties of methane are compared to hydrogen and gasoline in Table 4-2. Note that natural gas in the vapor form at nominal temperature and pressure (NTP) is about 6 times lighter than gasoline vapors. Thus the vapors resulting from a spill of LNG will rise after being warmed by the surrounding environment, while gasoline vapors will flow along the ground or water surface until dispersed by diffusion.

An important ramification of the cryogenic nature of LNG is that a trapped volume, e.g. between two valves in a pipe, the pressure increases as the fluid warms by heating from the surroundings. Good insulation can slow the warming process, but eventually, the entire contents of the system will become high pressure vapor if refrigeration is not restored. Thus, it is imperative that all potentially isolated sections of piping and tankage be vented through a relief valve. The inclusion of a relief valve for any enclosed volume is a standard practice of cryogenic design. 
Table 4-1. Comparison of LNG, diesel, and gasoline.

Fuel

Characteristic

LNG

Diesel

Gasoline

Storage

$112^{\circ} \mathrm{K}$

$300^{\circ} \mathrm{K}$

$300^{\circ} \mathrm{K}$

temperature

(at $1 \mathrm{~atm}$.)

$-260^{\circ} \mathrm{F}$

$60^{\circ} \mathrm{F}$

$60^{\circ} \mathrm{F}$

Operating

150 psig

50 psig

50 psig

pressure

Storage

100 psig

pressure

Storage

Above ground tanks

0.3 psig per foot

location

Vapor

1 atmosphere

Underground tanks

only, 0.3 psig per foot

pressure at

RT

Vapor

Rises

Settles

Settles

bouyancy

Flammable

$5-15 \%$ at $60^{\circ} \mathrm{F}$

Small

$0.3 \mathrm{psi}$

limits

Flash point of

liquids

Fluid behavior

Cryogenic-small spills evaporate quickly.

Large spills flow.

Fuel nozzles

Closed connection

Boiloff and venting

Routine

releases from

tanks

(minimized through design)

Fate of routine

Disperses in releases

atmosphere, oxidizes, greenhouse gas

Liquid sinks into ground water, vapors contribute to smog

\section{$1.2-8 \%$ at $60^{\circ} \mathrm{F}$}

$100^{\circ} \mathrm{F}$

$-50^{\circ} \mathrm{F}$

Like water - familiar

Like water-familiar

Open to air connection

Open to air connection

Very little venting

Little venting

Solvent

Liquid sinks into ground water, vapors contribute to smog

Low reactivity

Grease and oils have low solubility at liquid

Solvent

Solvent

reactivity

Solubility

CH4 temps

Autoignition

$1110^{\circ} \mathrm{F}$

$500-700^{\circ} \mathrm{F}$

$440-880^{\circ} \mathrm{F}$ 
Table 4-1. (continued).

Fuel

Characteristic

LNG

Diesel

Gasoline

Spark ignition

$0.3 \mathrm{~mJ}$

$0.3 \mathrm{~mJ}$

$0.3 \mathrm{~mJ}$

energy

Tanks

Double walled, steel,

Single wall, uninsulated

Single wall, uninsulated vacuum insulated

Handling

Not familiar

Familiar

Familiar

Movement

Pressure differentials or pumps

Odor

Odorless unless odorant

Pumps

Pumps

Distinct odor

Distinct odor chemical is added

Toxicity

No Threshold Limit

Value (TLV)

Inhalation

Simple asphyxiant, displaces oxygen

Fuel losses

Storage tanks are well sealed. At some stations a significant fraction (up to $25 \%$ ) can be lost in handling through venting warm tanks ${ }^{\mathrm{a}}$

\begin{tabular}{|c|c|c|c|}
\hline $\begin{array}{l}\text { Effects of fuel } \\
\text { losses }\end{array}$ & $\begin{array}{l}\text { Greenhouse gas, } \\
\text { transient fog }\end{array}$ & $\begin{array}{l}\text { Losses limited by EPA } \\
\text { rules on odor and } \\
\text { groundwater pollution }\end{array}$ & $\begin{array}{l}\text { Losses limited by EPA } \\
\text { rules on odor and } \\
\text { groundwater pollution }\end{array}$ \\
\hline Noise & $\begin{array}{l}\text { Unfamiliar noises; gas } \\
\text { venting, compressors } \\
\text { for } \mathrm{CNG} \text {. }\end{array}$ & Familiar & Familiar \\
\hline Touch & $\begin{array}{l}\text { Cryogenic burns, } \\
\text { hypothermia for long } \\
\text { exposure }\end{array}$ & Skin irritation, rashes & Skin irritation, rashes \\
\hline $\begin{array}{l}\text { Visual } \\
\text { differences }\end{array}$ & $\begin{array}{l}\text { Above ground tanks, } \\
\text { venting gases }\end{array}$ & Underground tanks & Underground tanks \\
\hline
\end{tabular}

Small losses from evaporation or spills. Leaking underground storage tanks are a pervasive problem.

Irritant

Irritant

Small losses from evaporation or spills. Leaking underground storage tanks are a pervasive problem. the greenhouse gasses. 
Table 4-2. Properties of hydrogen, methane and gasoline.

\begin{tabular}{|c|c|c|c|c|}
\hline Property & Hydrogen & Methane & Gasoline & Units \\
\hline Molecular Weight & 2.016 & 16.043 & 107 & amu \\
\hline Triple point pressure & 0.0695 & 0.1159 & - & atm \\
\hline Triple point temperature & 13.803 & 90.68 & 180 to 220 & $\mathbf{K}$ \\
\hline Normal boiling point (NBP) temperature & 20.268 & 11.632 & 310 to 478 & $\mathbf{K}$ \\
\hline Critical pressure & 12.759 & 45.387 & 24.5 to 27 & atm \\
\hline Critical temperature & 32.976 & 190.56 & 540 to 569 & $\mathbf{K}$ \\
\hline Density at critical point & 0.0314 & 0.1604 & 0.23 & $\mathrm{~g} / \mathrm{cm}^{3}$ \\
\hline Density of liquid at triple point & 0.077 & 0.4516 & - & $\mathrm{g} / \mathrm{cm}^{3}$ \\
\hline Density of solid at triple point & 0.06865 & 0.4872 & - & $\mathrm{g} / \mathrm{cm}^{3}$ \\
\hline Density of vapor at triple point & 125.597 & 251.53 & - & $\mathrm{g} / \mathrm{cm}^{3}$ \\
\hline Density of liquid at NBP & 0.0708 & 0.4226 & 0.7 & $\mathrm{~g} / \mathrm{cm}^{3}$ \\
\hline Density of vapor at NBP & 0.00134 & 0.00182 & 0.0045 & $\mathrm{~g} / \mathrm{cm}^{3}$ \\
\hline Density of gas at NTP & 83.764 & 651.19 & 4400 & $\mathrm{~g} / \mathrm{m}^{3}$ \\
\hline Density ratio: NBP liquid to NTP gas & 845 & 649 & 156 & \\
\hline Heat of fusion & 58.23 & 58.47 & 161 & $\mathrm{~J} / \mathrm{g}$ \\
\hline Heat of vaporization & 445.59 & 509.88 & 309 & $\mathrm{~J} / \mathrm{g}$ \\
\hline Heat of sublimation & 507.39 & 602.44 & - & $J / g$ \\
\hline Heat of combustion (low) & 119.93 & 50.02 & 44.5 & $\mathrm{~kJ} / \mathrm{g}$ \\
\hline Heat of combustion (high) & 141.86 & 55.53 & 48 & $\mathrm{~kJ} / \mathrm{g}$ \\
\hline Energy density & 8.49 & 21.14 & 31.15 & MJ/litre \\
\hline Specific heat $(\mathrm{Cp})$ of NTP gas & 14.89 & 2.22 & 1.62 & $\mathrm{~J} / \mathrm{g}-\mathrm{K}$ \\
\hline Specific heat $(\mathrm{Cp})$ of NBP liquid & 9.69 & 3.5 & 2.2 & $J / g-K$ \\
\hline Specific heat ratio $(\mathrm{Cp} / \mathrm{Cv})$ of NTP gas & 1.383 & 1.308 & 1.05 & - \\
\hline Specific heat ratio $(\mathrm{Cp} / \mathrm{Cv})$ of NBP liquid & 1.688 & 1.676 & - & 一 \\
\hline Viscosity of NTP gas & 0.0000875 & 0.00011 & 0.000052 & $\mathrm{~g} / \mathrm{cm}-\mathrm{s}$ \\
\hline Viscosity of NBP liquid & 0.000133 & 0.00113 & 0.002 & $\mathrm{~g} / \mathrm{cm}-\mathrm{s}$ \\
\hline Thermal conductivity of NTP gas & 1.897 & 0.33 & 0.112 & $\mathrm{~mW} / \mathrm{cm}-\mathrm{K}$ \\
\hline Thermal conductivity of NBP liquid & 1 & 1.86 & 1.31 & $\mathrm{~mW} / \mathrm{cm}-\mathrm{K}$ \\
\hline Surface Tension & 0.00193 & 0.01294 & 0.0122 & $\mathrm{~N} / \mathrm{m}$ \\
\hline Dielectric constant of NTP gas & 1.00026 & 1.00079 & 1.0035 & - \\
\hline Dielectric constant of NBP liquid & 1.233 & 1.6227 & 1.93 & - \\
\hline Index of refraction of NTP gas & 1.00012 & 1.0004 & 1.0017 & - \\
\hline Index of refraction of NBP liquid & 1.11 & 1.2739 & 1.39 & - \\
\hline Adiabatic sound velocity in NTP gas & 1294 & 448 & 154 & $\mathrm{~m} / \mathrm{s}$ \\
\hline Adiabatic sound velocity in NBP liquid & 1093 & 1331 & 1155 & $\mathrm{~m} / \mathrm{s}$ \\
\hline Compressibility factor $(Z)$ of NTP gas & 1.0006 & 1.0243 & 1.0069 & - \\
\hline Compressibility factor $(Z)$ in NBP liquid & 0.01712 & 0.004145 & 0.00643 & - \\
\hline Gas constant (R) & 40.7037 & 5.11477 & 0.77 & $\mathrm{~cm}^{3}-\mathrm{atm} / \mathrm{g}-\mathrm{K}$ \\
\hline Isothermal bulk modulus of NBP liquid & 50.13 & 456.16 & 763 & $\mathrm{MN} / \mathrm{m} 2$ \\
\hline Volume expansivity (b) of NBP liquid & 0.01658 & 0.00346 & 0.0012 & $/ \mathrm{K}$ \\
\hline \multicolumn{5}{|l|}{$\mathrm{NBP}=$ Normal boiling point } \\
\hline \multicolumn{5}{|l|}{$\mathrm{NTP}=1 \mathrm{~atm}$ and $20 \mathrm{C}\left(293.15^{\circ} \mathrm{K}\right)$} \\
\hline Source: (Hord 1978) & & & & \\
\hline
\end{tabular}


Another important physical property of methane is its lack of odor. Although ethyl mercaptan is added at $25 \mathrm{ppm}$ to give the odor we associate with natural gas, it cannot be used in LNG. At LNG temperatures, the mercaptan compounds freeze and are not carried along with the gas. There have been attempts to develop cryogenic odorants that will remain in solution in LNG, such as tetrahydrothiophene (THTP) (Mulliner 1974). The lack of odor greatly increases the importance of methane detectors to detect leaks and spills.

\subsubsection{Combustion Properties}

Four conditions are necessary for a self-sustaining combustion reaction. First, the fuel and oxygen must be intimately mixed in vapor form. Second, the proportions of fuel and oxygen must be within the flammability limits. Since we are here concerned with accidental combustion in air, we will discuss flammability limits as volume percent of fuel in air. Third, within the region where the fuel and air are within the flammability limits, there must be an energy source capable of initiating the chain of chemical reactions that constitutes the combustion process. The combustion process will not be self-sustaining if strong heat sinks are present within the reacting mixture of gases. These heat sinks may be in the form of water droplets, solid particles or the metal walls of a tank or pipe. The final condition necessary for a selfsustaining combustion reaction is that the chain reaction be complete and that intermediate products not be removed so as to interrupt the chain.

The combustion properties of hydrogen, methane and gasoline are compared in Table 4-3.

4.2.2.1 Flammability Limits. Methane and air are combustible when the methane volume fraction is between about 5 and 15 percent. The flammability limits are somewhat dependent on the initial temperature of the mixture, as shown in Table 4-4. When the vapor is very cold, the flammability limits are more narrow than at room temperature. Note also in the table that the density of methane at $175^{\circ} \mathrm{K}$ is about the same as air at $300^{\circ} \mathrm{K}$. Thus methane rises and disperses at temperatures above $175^{\circ} \mathrm{K}$.

4.2.2.2 Distinction Between Deflagration and Detonation. A deflagration is a subsonic combustion wave sustained by chemical reactions in a reactive mixture of gases. The diffusion of heat and species from the reaction zone into the unburned gases is responsible for the initiation of chemical reactions ahead of a deflagration. Thus the speed of propagation of a deflagration is limited by the molecular diffusivities within the gas to about one meter per second. A deflagration can be ignited by a weak energy source with an energy of only a fraction of a millijoule. Deflagration combustion pressures are generally much less than 1 psi.

The initiation of chemical reactions in a detonation, on the other hand, is due to an adiabatic shock compression wave passing through the urburned gases. The combustion reactions take place in highly compressed and preheated gases and the wave propagates very rapidly. Typical propagation velocities are of the order of kilometers per second and the pressures produced are generally several psi. The instantaneous ignition of a detonation in an unconfined mixture of reactive gases requires several orders of magnitude more energy than that necessary to ignite a deflagration. The energy necessary to initiate a detonation can be reduced if the mixture is confined by hard, reflecting walls, such that the shock can pass through the mixture several times.

4.2.2.3 Deflagration Conditions. As noted in Table 4-2, the energy necessary to ignite a deflagration is only about $0.3 \mathrm{~mJ}$ for either methane or gasoline. Such energy is easily available from a match, an open flame or a spark. As noted above, the flammability limits for methane are somewhat higher for methane ( 5 to 15 volume percent in air) than for gasoline ( 1.2 to 8 volume percent in air.) 
Table 4-3. Combustion properties of hydrogen, methane and gasoline.

\begin{tabular}{|c|c|c|c|c|}
\hline Property & Hydrogen & Methane & Gasoline & Units \\
\hline Limits of flammability in air & 4.0 to 75.0 & 5.3 to 15.0 & 1.0 to 7.6 & vol $\%$ \\
\hline Limits of detonability in air & 18.3 to 59 & 6.3 to 13.5 & 1.1 to 3.3 & vol \% \\
\hline $\begin{array}{l}\text { Stoichiometric composition } \\
\text { in air }\end{array}$ & 29.53 & 9.48 & 1.76 & vol \% \\
\hline $\begin{array}{l}\text { Minimum energy for ignition } \\
\text { in air }\end{array}$ & 0.02 & 0.29 & 0.24 & $\mathrm{~mJ}$ \\
\hline Autoignition temperature & 858 & 813 & 501 to 744 & $\mathbf{K}$ \\
\hline $\begin{array}{l}\text { Hot air-jet ignition } \\
\text { temperature }\end{array}$ & 943 & 1493 & 1313 & $\mathrm{~K}$ \\
\hline Flame temperature in air & 2318 & 2148 & 2470 & $\mathrm{~K}$ \\
\hline $\begin{array}{l}\text { Percentage of thermal } \\
\text { energy radiated from flame } \\
\text { to surroundings }\end{array}$ & 17 to 25 & 23 to 33 & 30 to 42 & $\%$ \\
\hline Burning velocity in NTP air & 265 to 325 & 37 to 45 & 37 to 43 & $\mathrm{~cm} / \mathrm{s}$ \\
\hline $\begin{array}{l}\text { Detonation velocity in NTP } \\
\text { air }\end{array}$ & 1.48 to 2.15 & 1.39 to 1.64 & 1.4 to 1.7 & $\mathrm{~km} / \mathrm{s}$ \\
\hline $\begin{array}{l}\text { Diffusion coefficient in NTP } \\
\text { air }\end{array}$ & 0.61 & 0.16 & 0.05 & $\mathrm{~cm}^{2} / \mathrm{s}$ \\
\hline $\begin{array}{l}\text { Diffusion velocity in NTP } \\
\text { air }\end{array}$ & $<2.00$ & $<0.51$ & $<0.17$ & $\mathrm{~cm} / \mathrm{s}$ \\
\hline Buoyant velocity in NTP air & 1.2 to 9.0 & 0.8 to 6.0 & Nonbuoyant & $\mathrm{m} / \mathrm{s}$ \\
\hline $\begin{array}{l}\text { Maximum experimental safe } \\
\text { gap in NTP air }\end{array}$ & 0.008 & 0.12 & 0.07 & $\mathrm{~cm}$ \\
\hline Quenching gap in NTP air & 0.064 & 0.203 & 0.2 & $\mathrm{~cm}$ \\
\hline $\begin{array}{l}\text { Detonation induction } \\
\text { distance in NTP air }\end{array}$ & $\mathrm{L} / \mathrm{D}=100$ & & & \\
\hline Limiting oxygen index & 5 & 12.1 & 11.6 & vol \% \\
\hline $\begin{array}{l}\text { Vaporization rates (steady } \\
\text { state) of liquid pools without } \\
\text { burning }\end{array}$ & 2.5 to 5.0 & 0.05 to 0.5 & $\begin{array}{l}0.005 \text { to } \\
0.02\end{array}$ & $\mathrm{~cm} / \mathrm{min}$ \\
\hline $\begin{array}{l}\text { Burning rates of spilled } \\
\text { liquid pools }\end{array}$ & 3.0 to 6.6 & 0.3 to 1.2 & 0.2 to 0.9 & $\mathrm{~cm} / \mathrm{min}$ \\
\hline Flash point & Gaseous & Gaseous & 230 & $\mathbf{K}$ \\
\hline Toxicity & $\begin{array}{l}\text { Nontoxic } \\
\text { (asphyxiant) }\end{array}$ & $\begin{array}{l}\text { Nontoxic } \\
\text { (asphyxiant) }\end{array}$ & $\begin{array}{l}\text { Slight } \\
\text { (asphyxiant) }\end{array}$ & Slight (asphyxiant \\
\hline Energy of explosion, & 24 & 11 & 10 & $\mathrm{~g}$ TNT/g fuel \\
\hline Energy of explosion & 1.71 & 4.56 & 7.04 & $\begin{array}{l}\text { g TNT } / \mathrm{cm}^{3} \text { NBP liquid } \\
\text { fuel }\end{array}$ \\
\hline Energy of explosion & 2.02 & 7.03 & 44.22 & $\begin{array}{l}\mathrm{kg} \mathrm{TNT} / \mathrm{m}^{3} \mathrm{NTP} \\
\text { gaseous fuel }\end{array}$ \\
\hline \multicolumn{5}{|c|}{$\mathrm{NTP}=1 \mathrm{~atm}$ and $20 \mathrm{C}\left(293.15^{\circ} \mathrm{K}\right)$} \\
\hline
\end{tabular}


Table 4-4. Temperature dependence of flammability limits for methane-air mixtures.

\begin{tabular}{|c|c|c|c|c|c|c|}
\hline \multicolumn{3}{|c|}{ Temperature } & \multirow{2}{*}{$\begin{array}{c}\text { Lower } \\
\text { Flammability } \\
\text { Limit } \\
(\%)\end{array}$} & \multirow{2}{*}{$\begin{array}{c}\text { Upper } \\
\text { Flammability } \\
\text { Limit } \\
(\%) \\
\end{array}$} & \multirow[b]{2}{*}{$\begin{array}{r}\mathrm{rCH} 4 \\
\mathrm{~kg} / \mathrm{m} 3\end{array}$} & \multirow[b]{2}{*}{$\begin{array}{c}\mathrm{r} \text { air } \\
\mathrm{kg} / \mathrm{m} 3\end{array}$} \\
\hline$\underline{\mathrm{K}}$ & C & $\underline{F}$ & & & & \\
\hline 111.6 & -161 & -258.5 & 5.7 & 13.0 & 1.8159 & - \\
\hline 150 & -123 & -189.4 & 5.5 & 13.4 & 1.3229 & - \\
\hline 175 & -98 & -144.4 & 5.4 & 13.7 & 1.1279 & - \\
\hline 200 & -73 & -99.4 & 5.4 & 13.9 & 0.9843 & 1.7690 \\
\hline 225 & -48 & -54.4 & 5.3 & 14.2 & 0.8726 & - \\
\hline 250 & -23 & -9.4 & 5.2 & 14.5 & 0.7843 & - \\
\hline 300 & 27 & 80.6 & 5.0 & 15.0 & 0.6527 & 1.1769 \\
\hline 350 & 77 & 170.6 & 4.8 & 15.6 & 0.5593 & - \\
\hline 400 & 127 & 260.6 & 4.6 & 16.1 & 0.4890 & 0.8826 \\
\hline
\end{tabular}

4.2.2.4 Detonation Conditions. D. C. Bull and coworkers (Bull 1976; Baker 1991) performed a series of experiments to determine the energy needed to initiate a detonation in mixtures of methane and oxygen diluted by nitrogen. In his experiments, the gaseous mixtures were confined by thin plastic membranes, thus simulating an unconfined cloud of methane and air. The mixture consisted of $\mathrm{CH}_{4}+2 \mathrm{O}_{2}$ $+\mathrm{x} \mathrm{N}_{2}$.

He found that a detonation could be initiated by $1 \mathrm{gm}$ of the high explosive Tetryl at $\mathrm{x}=2$, but that $1000 \mathrm{gm}$ of Tetryl was required at $x=6$. Extrapolating to a mixture of methane and air $(x=7.4)$ he found that $22 \mathrm{~kg}$ of Tetryl would be necessary to initiate a detonation. That quantity of Tetryl releases about $300 \dagger \mathrm{MJ}$, some twelve orders of magnitucle higher than the spark ignition energy. Tests with other gases showed that ethane/air would detonate with about 50 grams of Tetryl, propane/air with 90 grams and butane/air with about 100 grams.

The lower energy requirement for ethane is important when considering the use of 'weathered' LNG, which may contain several percent ethane due to the selective vaporization of methane from the liquid. Weathering is discussed in a later section.

\subsubsection{Chemical Hazards}

In additional to the hazards of accidental combustion of LNG, its ability to displace breathing air and to cause cryogenic burns must be considered.

4.2.3.1 Toxicity Limits. Natural gas, per se, is non-toxic. However, it can be an asphyxiant if air is displaced and the oxygen content of the breathing atmosphere falls below 15\% (ACGIH 1996). Since methane at temperatures below $165^{\circ} \mathrm{K}$ is denser than air at room temperature, cold methane gas will pool in low sections of a facility, such as the bund enclosure, pumping pits, basements and pits in vehicle maintenance facilities. Maintenance facilities specifically designed for $L N G$ vehicles do not have pits 
(Thomas 1996). Note that the danger of asphyxiation is increased in LNG facilities due to the absence of an odorant in the gas, as discussed earlier.

Considering LNG leaks and the volume expansion that occurs upon boiling, the issue of displacing air is a toxicity concern. Workers are restricted by law from entering atmospheres with less than $19.5 \%$ volume of oxygen (normally $21 \%$ at sea level) without precautions (OSHA 1996) such as breathing apparatus. This $19.5 \%$ value is for workers of average health; it may be taxing to children and elder people. No guidelines for acceptable levels of oxygen deficiency for the general public were found in the literature. The expectation is that any deficiency should be less than that allowed for healthy workers (i.e., only oxygen concentrations greater than 19.5\%). The Compressed Gas Association (CGA 1992) gives some symptoms of oxygen deficiency. At values of $12-15 \%$, judgment and coordination are impaired, so it is questionable if a person can evade the hazard without assistance. At oxygen concentrations at the 4 to $6 \%$ level, a person can enter a coma in less than a minute, followed by convulsions and death.

4.2.3.2 Carcinogenicity. Methane, or natural gas, is not a carcinogen; it has no threshold limit value. It is a simple asphyxiant gas as indicated above.

\subsubsection{Cryogenic Hazards}

As a cryogenic liquid, LNG can cause burns to workers if it comes in contact with the skin. The hazard is further complicated since LNG is about $42 \%$ the density of water and handled at pressures of 15 to 250 psi. Therefore the possibility of cold liquid spraying into a worker's face or onto a worker's clothing must be guarded against. Personal protective equipment (PPE), such as impervious gloves that extend to the elbow, full face shields with chin protection and an impervious apron, is necessary.

According to the fueler in one location we visited, if LNG hits an exposed portion of ordinary clothing, the worker should immediately hold that area of clothing away from the skin to prevent cryogenic burns. This action is also given in LNG safety manuals. It is also important that 'cut-offs' and trousers with cuffs not be allowed in the refueling area. Cut-offs expose the legs to immediate cryogenic burns. Trousers with cuffs can hold a pool of cryogenic liquid next to the ankles. Note that at other locations visited, workers refueling with LNG did not wear their protective equipment when refueling. In some instances the protective equipment consisted only of short (wrist-length) work gloves and safety glasses.

A second cryogenic health hazard is associated with LNG vapors; breathing cold vapors from LNG evaporation or boiling can damage the lungs (GRI 1994). While methane does not chemically react with the lungs (i.e., it is a 'simple' asphyxiant that creates a hazard by displacing air), the cold vapor from LNG can cause "frosting the lungs". This effect is also a health concern in extremely cold winter weather. Breathing super cold air or methane vapor can frost or freeze lung tissues. When the tissues freeze, ice forms. Since ice occupies more volume than a similar quantity of water and since ice crystals are also sharp, the cells can be ruptured and will likely die upon thawing. If alveoli cells are destroyed, a person could experience edema, pneumonia-like symptoms, and emphysema-like symptoms. The type of symptoms and their severity are directly related to the severity of exposure.

Regarding potential component damage caused by exposure to LNG, all components normally in contact with LNG are metals that do not undergo a ductile to brittle transition (DBT), e.g., austenitic stainless steel, aluminum, brass, copper. However, the ordinary structural steel commonly used for buildings, ships, etc. does undergo a DBT at $200-300^{\circ} \mathrm{K}$. Our research has found reports of cracking of carbon steel deck plates on LNG carrier ships as a result of spills on the deck. The spill did not necessarily pool on the deck, but enough heat was removed from the deck plates to cause cracking. The cracking was due to a combination of contraction and embrittlement (Harris 1993). In these incidents, the damage was 
apparently localized and was generally repaired at the next scheduled maintenance. However, the DBT phenomenon presents an opportunity for a minor spill to become a major spill if a structural steel component, such as a tank support colurnn, fails due to embrittlement.

\subsection{Phenomena in Routine Handling}

Because LNG is a cryogenic fluid, its routine handling is different from the handling of gasoline and diesel fuel. This section discusses how the composition of LNG can change over time due to the selective vaporization of methane ("weathering"), how differences in density between new LNG and that already in the storage tank can cause a sudden pressure rise in the ullage volume ("rollover"), and how vapor can be evolved in a flowing stream ("geysering"). It also discusses the issues of static electricity buildup and vapor accumulation and associated potential hazards.

\subsubsection{Weathering}

LNG as delivered to a storage facility often has a mixture of methane, ethane, propane and butane, with lesser amounts of other hydrocarbons. Typically, the methane content of LNG is at least $95 \%$, though weathered LNG can have methane contents as low as $85 \%$. While weathering is an issue in peakshaving plants, the LNG used for vehicles is generally of high purity (e.g. 99.5\% methane, Pentz 1995) and is used at a high rate. Both factors greatly decrease the importance of weathering in the use of LNG as a vehicle fuel.

Although weathering is generally not important in vehicular use, operators should be familiar with the phenomena when handling impure fuel or storing it for extended periods. A comparison of the vapor pressures and heats of combustion for four energy gases is shown in Table $4-5$. Note that, at $150^{\circ} \mathrm{K}$, the vapor pressure of methane is two orders of magnitude higher than that of ethane and probably three and four orders of magnitude higher than that of propane and butane, respectively. Thus the ullage volume at the top of a storage tank of LNG will contain vapor that is at least $99 \%$ methane. As that vapor volume is vented or consumed, methane will be selectively extracted from the liquid and the methane content of the liquid will decrease. Since the volumetric energy content of ethane is nearly twice that of methane, the energy density of the remaining fuel increases.

Weathering in vehicle tanks is not a problem when the vehicles are frequently refueled. Operational issues include engine knock (and possible damage) caused by the use of lower octane fuel (the octane rating of pure methane is about 140 , while that of a $90 \%$ methane $/ 10 \%$ ethane mixture is about 134). Weathering

Table 4-5. Vapor pressures and heats of combustion for four energy gases.

Vapor Pressures

(MPa)

\begin{tabular}{|c|c|c|c|c|c|c|}
\hline & $100^{\circ} \mathrm{K}$ & $125^{\circ} \mathrm{K}$ & $150^{\circ} \mathrm{K}$ & $175^{\circ} \mathrm{K}$ & $200^{\circ} \mathrm{K}$ & $\begin{array}{c}\text { Heat of } \\
\text { Combustion }\end{array}$ \\
\hline & $-279.4^{\circ} \mathrm{F}$ & $-234.4^{\circ} \mathrm{F}$ & $-189.4^{\circ} \mathrm{F}$ & $-144.4^{\circ} \mathrm{F}$ & $-99.4^{\circ} \mathrm{F}$ & $(\mathrm{MJ} / \mathrm{m} 3)$ \\
\hline Methane & 0.03451 & 0.2694 & 1.041 & 2.78 & - & 39.77 \\
\hline Ethane & - & - & 0.0096 & 0.2563 & 0.2200 & 69.67 \\
\hline
\end{tabular}




\begin{tabular}{|c|c|c|c|c|c|c|}
\hline Propane & - & - & - & - & 0.0200 & 99.16 \\
\hline Butane & - & - & - & - & 0.0019 & 128.57 \\
\hline
\end{tabular}

is a safety issue in that the energy required to initiate a detonation in ethane is about two orders of magnitude lower than that for methane.

The rate of weathering is dependent on the rate of heat leakage through the insulation into the storage tank, since the boil-off of the methane is the primary heat absorption process. Shah and Aarts (Shah 1974) have developed correlations for predicting the rate of weathering in storage tanks. Typically, weathering times are around 150 days for a $48,000-\mathrm{m}^{3}$ storage tank with a boil-off rate of $0.05 \%$ per day. Weathering times for a $125,000-\mathrm{m}^{3} \mathrm{LNG}$ carrier ship having a boil-off rate of $0.25 \%$ per day are around 10 days.

Weathering can be reduced by several techniques. High methane contents (e.g. 99\%) can be specified in the fuel purchase contract. Fuel to be consumed in a vehicle should the taken from the liquid contents of the vehicle tank to prevent a long term buildup of ethane. Both storage and vehicle tanks should be well insulated to reduce vaporization in the tanks as much as possible. The effects of weathering in large storage tanks can also be reduced through mechanical refrigeration and reliquefaction of the ullage vapor. Vehicle tanks are designed to use only $90 \%$ of the gross tank volume to reduce the rate of pressure rise in the ullages and the subsequent venting of methane-rich vapors. In order to prevent venting of the vehicle tanks in potentially hazardous locations, such as within an enclosure, fueling schedules should be arranged to assure rapid turnover of the fuel in both the storage and vehicle tanks.

\subsubsection{Rollover}

Rollover is a phenomenon seen in large ( $>30,000$-gallon) storage tanks when new LNG is added to LNG of a different composition already in the tank. The mixing of the two compositions can cause large, unexpected and sudden releases of vapor, commonly referred to as 'rollover.' This rollover causes a pressure rise in the tank and may challenge the pressure or venting capacity of the tank. No damage has been reported in any incidents of rollover, but the magnitude and rate of vapor release must be accounted for in storage tank design (Drake 1973).

New LNG being added to a storage tanks is usually higher in methane content than the LNG already present, due to weathering. The colder, lighter ${ }^{\mathrm{h}} \mathrm{LNG}$ added to the top of the tank forms one convective cell, driven by heat inleakage through the walls of the tank and boiloff at the surface. The older, heavier, warmer LNG already in the tank forms a cell at the bottom of the tank, also driven by heat inleakage, but without boiloff. These cells remain separate until heat and mass transfer processes bring the upper and lower layer densities close enough to allow rapid mixing. When that mixing takes place, the warmer lower layer in the tank heats the methane-rich upper layer, causing the rapid evolution of methane gas into the ullage volume.

g. Note that pressure in the ullage volume increases faster when the vehicle is not in use than while fuel is being consumed.

h. The new LNG has higher methane content and is therefore lighter than the older, weathered methane, 
Large bulk tanks are equipped with top-fill vapor collapse headers which can reduce any possible effects of associated with non-methane content of the vapor space. Operational procedures should assure the use of the top-fill headers when warranted.

The dangers of rollover can be reduced or eliminated by three actions in the loading of an LNG tank. First, the formation of separate convective cells can be avoided if there is adequate mixing of the incoming LNG with all the LNG previously in the tank. This mixing can be done with recirculation pumps, which, however, increase the heating of the LNG. Another approach uses the momentum of the feed stream to mix the incoming with the stored LNG. Buoyant forces can aid in mixing if lighter LNG is always bottomloaded and heavier LNG is always top loaded.

Overpressurization of the storage tank during a rollover can be avoided if venting or pressure capacity is adequate to handle the maximum amount of vapor that can be generated during a rollover. Finally, concerns for rollover (and weathering) can be reduced if the range of LNG compositions to be added to the tank is limited. In recent years, the methane content of LNG has increased and become more consistent because of more thorough removal of ethane, propane and butane at the liquefaction plant.

\subsubsection{Geysering}

Geysering is caused by heat inleakage to a feed or vent pipe connected to both the bottom and upper portions of a deep storage tank (Morioka 1986). Because the area to volume ratio is higher for the pipe than for the overall tank, the fluid in the pipe becomes heated above saturation, forming bubbles and decreasing in density. The bubbles cause upward flow through the pipe and possible rapid methane vapor evolution in the ullage volume. Because the heat transfer rates are low and the mass of LNG is large, geysering sometimes develops into a transient phenomenon called bumping. Bumping is more frequent in vertical pipes. Transient boiling and condensation within piping to an LNG storage tank can also cause 'water hammer' and possible damage to the piping system.

\subsubsection{Static Electricity and Grounding}

Static electricity is the separation of positive and negative charges and the continued separation of the charges because no conducting path is available for the charges to reunite. Static electricity can be generated by friction in flowing low concluctivity fluids, such as gasoline or LNG. Static electricity can also be generated by friction between solid surfaces or by connection to atmospheric static discharges. Five conditions must be present to produce a static spark capable of igniting a flammable mixture:

1. A mechanism for generating the static charge separation

2. A means of accumulating the charge, i.e. a capacitance

3. A suitable gap across which the previously separated charges can flow

4. A voltage difference across the gap sufficient to cause electrical breakdown

5. Sufficient energy released in the spark to meet the minimum ignition energy requirements of the flammable mixture (Mancini 1988).

As discussed earlier, the ignition energy for both methane and gasoline is about $0.3 \mathrm{~mJ}$. Gasoline is usually carried in metal tanks and the flexible hose and spout are electrically bonded. Furthermore, the 
area surrounding gasoline pumps is usually concrete, to resist chemical attack from spilled gasoline. The electrical conductivity of concrete is about two orders of magnitude higher than that of asphalt. Thus charges separated by friction in the flow of gasoline are reunited along paths in the hose, concrete and tires.

Because of its cryogenic properties, LNG is transferred in metal rather than rubber or plastic hoses and tanks. Seals are also generally metallic. Thus separated charges flow through the metal bellows hoses and nozzle connections without sparking. For added safety, a separate grounding wire has been provided at each of the refueling stations we visited. It is not clear that such a separate wire is needed. (As it turns out, because the wire can become entangled with the LNG fill hose, particularly in one facility, the grounding wire was not always used. If the function of the grouding wire is needed, the design of future stations should rely on intrinsic grounding and bonding mechanisms and not rely on the operator's attaching a separate grounding wire.)

\subsubsection{Vapor Accumulation}

The accident at Cove Point, Maryland on October 6, 1979, in which one person was killed, was the result of vapor accumulation in a motor controller building. The vapor flowed into the building through an improperly sealed conduit from a submerged pump to the building. Since the LNG was not odorized, and since there were no methane sensors in the building, the supervisor did not recognize that natural gas had accumulated in the building and a spark from the control circuitry in a cabinet ignited an explosion (see Section 2.3.3).

While accumulation of a flammable mixture and ignition of an explosion of methane in the open air is difficult, vapor accumulation within a building can easily result in large volumes of an explosive mixture. Furthermore, the reflection of shock waves off the interior walls, floor and ceiling intensify the shock heating process and therefore reduce the energy required to initiate a detonation. Thus a prime concern in the handling of LNG is the accumulation of vapors within enclosures.

After the Cove Point accident a number of changes were mandated in the design and construction of LNG facilities. Among those changes was the requirement for vents and a section of solid conductor in any conduit run between any source of natural gas and an ignition source. The vents are located outside of any enclosure and release any vapors flowing within the conduit. The solid conductor interrupts the vapor path in the interstitial passages between stranded conductor. Tests done after the Cove Point accident indicated that vapors could flow along the interstices in stranded wire if the driving pressure is sufficient (PAR 1980, Van Meerbeke 1982, IFC 1980).

\subsection{Phenomena Under Accident Conditions}

Under accident conditions, a quantity of LNG may be spilled on the ground or on a water surface. The flow, dispersion, and possible ignition of the LNG vapors following such a spill in large part determine the severity of the accident. As a low density cryogenic liquid, LNG has several characteristics different from those of more common liquid fuels.

\subsubsection{Spills}

LNG is stored and transferred at pressures of 45 to 200 psi ( 0.3 to $1.4 \mathrm{MPa})$. As noted in Table $4-2$, the viscosity of liquid methane at $112^{\circ} \mathrm{K}$, its boiling point at atmospheric pressure, is $0.00113 \mathrm{~g} / \mathrm{cm}-\mathrm{s}$. 
By comparison, the viscosity of gasoline is $0.002 \mathrm{~g} / \mathrm{cm}-\mathrm{s}$ and that of water is roughly the same in the range $300^{\circ} \mathrm{K}$ to $400^{\circ} \mathrm{K}$. Thus, LNG can be expected to spill and flow somewhat more easily than water.

\subsubsection{Dispersion}

The dispersion of methane after a spill of LNG has been the subject of several series of experiments over the last thirty years. Several phenomena govern the behavior of methane after the open pool of liquid has been established. The LNG is vaporized by heat input from the underlying water or soil, from the air above the pool and from insolation. Spills on water can continue to draw heat from the water because of its high thermal capacity and convective currents. However, spills on soils cause freezing of the soil and a marked decrease in thermal conductivity. In a deep pool of LNG, convective currents will be formed in the pool itself.

The critical parameter in the investigation of vapor dispersion is the extent of the region wherein the methane concentration is between the upper and lower flammability limits, i.e. between 5 and 15 volume percent. Unlike gasoline and propane, methane is lighter than air when in thermal equilibrium and thus the vapor will rise when warmed sufficiently by the surroundings. As stated earlier in this section, methane at $165^{\circ} \mathrm{K}$ has the same density as air at $300^{\circ} \mathrm{K}$. Thus, the methane vapor will begin to rise as soon as it is warmed (by the water, soil and air) from its release temperature of $115-120^{\circ} \mathrm{K}$ to $165^{\circ} \mathrm{K}$.

Finite element models have been developed to simulate the dispersion of LNG and its vapor after a spill. These models and the experiments that validated the models are discussed later in this section and in Chan (1992).

\subsubsection{Boiling Liquid Expanding Vapor Explosions}

A Boiling Liquid Expanding Vapor Explosion (BLEVE) occurs as a result of a fire surrounding a pressure or other storage vessel containing flammable liquid. Typically, the fire is fed by a leak in the storage vessel. The liquid within the vessel heats up and the pressure rises. Relief valves are challenged to open at their set point pressures, but if the valves are not large enough, or do not function on demand, then the flow through the valve is insufficient to reduce the pressure and in any case, flammable liquid or vapor issuing from the relief valve further intensifies the fire beneath the storage vessel. The walls of the vessel begin to creep as their temperature rises and finally the wall fails, often in a lower portion of the tank exposed to the most intense external fire. At this point the remaining contents of the tanks are discharged to the atmosphere in a preheated condition and are immediately ignited by the initial fire, exploding in a classic mushroom fireball. The blast effects of such explosions are not usually too severe, but debris may be scattered over a wide area (Thomson 1987). Often there is a domino effect, where the first BLEVE scatters debris which lights further fires and causes additional vessel failures. In the U.S., there were twelve BLEVEs between 1970 and 1975 (GAO 1978). Several of these were in strings of railroad tank cars carrying propane. A derailment would cause the failure of one or a few cars and the ensuing fire would cause a BLEVE in those cars with a domino effect to the other cars.

Several distinctions between propane and LNG tank cars are worthy of note. First, since LNG must be shipped at $112-130^{\circ} \mathrm{K}$, the storage and transport tanks are well insulated from the external atmosphere. The external shell must be strong enough to maintain the annular vacuum insulation, but the pressure boundary is the internal shell. On the other hand, tanks for the shipment and storage of propane are singlewalled and often uninsulated, since propane is a liquid at $300^{\circ} \mathrm{K}$ and $1.0 \mathrm{MPa}(145 \mathrm{psi})$. Thus heating of the walls and heat transport to the stored liquid are much more rapid with propane than with LNG. Our 
research has found no reports of BLEVEs involving LNG, though we have obtained reports of propane BLEVEs from several sources.

The incidence of propane BLEVEs has decreased markedly since the 1970 s due to federally mandated improvements to railcars, such as end shields for the tanks, couplers which would not slip apart during a derailment and protection of valving. The improved couplers were necessary because the initial tank failures were often caused by the coupler of an adjacent car.

\subsubsection{Unconfined Vapor Cloud Explosions}

Unconfined vapor cloud explosions (UVCEs) occur when a cloud of flammable vapor is released and becomes mixed with the air over a period of time before ignition occurs. If the mixture then detonates, it produces a shock wave traveling at a few kilometers per second and overpressures of a few atmospheres.

As discussed elsewhere in this section, Bull and coworkers (Bull 1976) ignited UVCEs in mixtures of methane, oxygen and nitrogen. He found, by extrapolation, that $22 \mathrm{~kg}$ of high explosive would be necessary to detonate a methane air mixture, but that propane and ethane could be ignited by a few tens of grams. Furthermore, at the same temperature and pressure, methane is about 0.55 the density of air, while ethane and propane are 1.03 and 1.52 times the density of air, respectively. Thus, methane disperses into the atmosphere as it heats while ethane, propane and heavier hydrocarbons vapors can flow into low spots at ground level. The likelihood of a methane cloud detonation therefore appears to be low. ${ }^{i}$

A methane cloud deflagration, on the other hand, is possible. Gugan (1979) reports an unconfined vapor cloud explosion involving a perhaps $500 \mathrm{~kg}$ cloud of methane at a chemical process plant on a cold $\left(-12^{\circ} \mathrm{F}\right)$ day. The cloud edge was some 50 meters away from its source when ignition occurred. The explosion broke several windows (the flying glass caused numerous injuries, some of them serious) but otherwise caused little damage. The damage observed (which impliess a relatively slow speed of pressure rise) indicates that the explosion did not involve a detonation.

\subsection{Experiments}

The U.S. Department of Energy (DOE) has constructed the Liquefied Gaseous Fuels Spill Test Facility (LGFSTF) on and adjacent to the dry bed of Frenchman Lake at the Nevada Test Site, 75 miles northwest of Las Vegas (Leone 1990). One feature of the LGFSTF is the Large Scale Test Area, where the storage tanks can supply spill rates of 5 to $100 \mathrm{~m}^{3} / \mathrm{min}$ (1000 to $26,000 \mathrm{gpm}$ ) onto ground or water surfaces. The cryogenic system can supply total spill volumes of 5 to $200 \mathrm{~m}^{3}$ ( 1000 to 53,000 gallons). The LGFSTF has the capability to test phenomena such as source definition, dispersion, rapid phase transition, pool fire and vapor burn.

In 1987 the Gas Research Institute and the U.S. Department of Transportation (DOT) performed a series of five releases of LNG ranging from 6500 gallons to 26,000 gallons. The program tested the effectiveness of vapor fences in mitigating $L N G$ releases at peak-shaving plants.

i. It is not known if this possibility should be discounted entirely, as deflagration-to-detonation transitions are possible in UVCEs, depending on the size of the cloud and various environmental conditions. 
The parameters for four of the five 1987 experiments are shown in Table 4-6 (Chan 1992). The last column contains the results of a numerical simulation of the Falcon-4 experiment in which the

vapor-dispersing fence was removed from the model. Note that the spill volumes range from 5,400 to 17,500 †allons, easily encompassing the largest size tanker truck expected at an LNG refueling station.

The first three tests had spill durations of less than three minutes, while the fourth test had a spill duration of slightly over five minutes. Winds were light and the weather conditions were moderately stable. The spills were made on the surface of a $60 \mathrm{~m} \times 40 \mathrm{~m}$ pond, about $0.76 \mathrm{~m}$ deep. The fiberglass vapor fence surrounding the pond was $44 \mathrm{~m}$ wide and $88 \mathrm{~m}$ long and $8.7 \mathrm{~m}$ high. The test area also included a billboard-line barrier $17.1 \mathrm{~m}$ long and $13.3 \mathrm{~m}$ high. The purpose of the tests was to validate the codes and

Table 4-6. Parameters for falcon experiments.

\begin{tabular}{|c|c|c|c|c|c|}
\hline & Falcon-1 & Falcon-2 & Falcon-3 & Falcon-4 & $\begin{array}{c}\text { Falcon-4 } \\
\text { (simulation, no fence) } \\
\end{array}$ \\
\hline Spill volume $\left(\mathrm{m}^{3}\right)$ & 66.4 & 20.6 & 50.7 & 44.9 & 44.9 \\
\hline Spill volume (gallons) & 17540 & 5440 & 13400 & 11860 & 11860 \\
\hline Spill rate $\left(\mathrm{m}^{3} / \mathrm{min}\right)$ & 28.7 & 15.9 & 18.9 & 8.7 & 8.7 \\
\hline Spill rate (gpm) & 7580 & 4200 & 4990 & 2300 & 2300 \\
\hline $\begin{array}{l}\text { Average windspeed at } \\
2 \mathrm{~m}(\mathrm{~m} / \mathrm{s})\end{array}$ & 1.7 & 4.7 & 4.1 & 5.2 & 5.2 \\
\hline $\begin{array}{l}\text { Average windspeed at } \\
2 \mathrm{~m}(\mathrm{mph})\end{array}$ & 3.8 & 10.5 & 9.2 & 11.6 & 11.6 \\
\hline Pasquill stability class & G & $\mathrm{D}$ & $\mathrm{D}$ & $\mathrm{D} / \mathrm{E}$ & $\mathrm{D} / \mathrm{E}$ \\
\hline $\begin{array}{l}\text { Downwind distance to } \\
2.5 \text { volume } \% \\
\text { concentration (m) }\end{array}$ & 440 & {$[200]$} & 353 & 203 & {$[365]$} \\
\hline $\begin{array}{l}\text { Downwind distance to } \\
2.5 \text { volume } \% \\
\text { concentration (ft) }\end{array}$ & 1444 & [656] & 1158 & 666 & [1198] \\
\hline $\begin{array}{l}\text { Downwind distance to } \\
5 \text { volume } \% \\
\text { concentration (m) }\end{array}$ & 330 & {$[70]$} & 230 & 28 & {$[230]$} \\
\hline $\begin{array}{l}\text { Downwind distance to } \\
5 \text { volume \% } \\
\text { concentration (ft) }\end{array}$ & 1083 & {$[230]$} & 755 & 92 & {$[755]$} \\
\hline
\end{tabular}

wind tunnel model used in simulating vapor dispersion and to assess the effectiveness of vapor fences for mitigating LNG vapor dispersion hazards in the event of a large accidental spill. The code FEM3A generally predicted the results of the experiments within $25 \%$, though the experimental downwind $5 \%$ concentration distance was less than $45 \%$ of the distance predicted by the model. 
Experimental results and the simulation of Falcon-4 without a vapor fence indicated that a vapor fence has the following advantages: significantly reduced methane concentrations in the near field, delayed cloud arrival times at downwind locations and a much shorten downwind distance where the methane concentration is in the flammable range. However, a vapor fence retains the vapor cloud longer near the source, thus increasing the potential for ignition. Methane concentrations within the vapor fence were above the upper flammable limit $(15$ vol. \%) for the first four minutes of the Falcon-1 and Falcon-4 tests. (Interior concentrations were not reported for the other tests.)

Earlier, some 130 experimental spills of LNG on water were carried out between 1970 and 1981 (Puttock 1982). Liquid volumes spilled ranged from $0.04 \mathrm{~m}^{3}$ to $198 \mathrm{~m}^{3}$. Sixteen of the tests were intentionally ignited. Spills onto ground were conducted by Gaz de France at Nantes in 1972 and by Battelle/AGA near San Clemente in 1974. In the ground spills, evaporation from a soil surface rapidly decreased as the soil cooled and the maximum hazard occured soon after the LNG was spilled. Because of water in the soil and humidity in the air, a visible cloud was observed to separate from the plume remaining after the initial burst of vapor. It was found from concentration measurements that the flammable region was always contained within the visible cloud.

Shell conducted about ten experimental spills of LNG, eight continuous and two instantaneous in late summer 1980 at Maplin Sands along the Thames. Spill volumes were between $4 \mathrm{~m}^{3}$ and $20 \mathrm{~m}^{3}$. Instrumentation surrounded the spill site on a tidal flat in a semi-circular pattern, $400 \mathrm{~m}$ in radius. In one of the tests, LNG was injected as a jet $0.25 \mathrm{~m}$ below the water surface at the rate of $3.9 \mathrm{~m}^{3} / \mathrm{min}$ for 5.0 minutes. The LNG formed a highly buoyant cloud which passed above even the closest methane sensors located $2.4 \mathrm{~m}$ above the sea surface and $40 \mathrm{~m}$ from the release point. This test is good indication that the rapid phase transitions caused by mixing of $L N G$ and water are not violent.

\subsection{Current Outstanding Issues in LNG Safety}

In an October 15, 1996 memo to Thomas Grumbly (Hunt 1996) Peter Hunt raised a number of important safety issues in the use of LNG as a transportation fuel. The issues involve:

- The hazard of a fire or explosion in the methane vapor cloud released in an LNG spill

- The danger of lung damage or asphyxiation due to the low temperature of the vapor cloud

- Material failures due to contraction and embrittlement if structural steel is exposed to LNG

- The rapid phase transition that will occur if LNG is injected into water or another warm liquid.

Our review of the literature and field observations lead to the following conclusions about the status of each of theses issues.

Regarding the first issue, DOE and the LNG industry have conducted both experiments and numerical simulations of the release and dispersions of large quantities of $L N G$, as noted in the preceding section. These tests have resulted in the development of guidelines for the size of LNG facilities to assure no offsite transport of flammable mixtures (Ong 1985). However, it is not clear if these guidelines are being met; based on the results of the Falcon tests and associated simulations, it appears that under some 
weather conditions, credible (if quite unlikely) spills at two of the facilities visited can lead to flammable concentrations offsite.

The DOE and industry tests and simulations have also led to the development of vapor fences surrounding LNG storage tanks that greatly reduce the region of flammability (Chan 1992). Again, it is not clear that these fences are widely deployed; none of the facilities visited had fences especially designed to enhance LNG vapor dispersion. (Note that the effectiveness of conventional, e.g., chain link, fences in dispersing LNG is also unclear.)

If a large release occurs and is not quickly dispersed, unconfined methane vapor cloud explosions are possible (see Section 4.4.4). Although such explosions are unlikely to involve detonations, deflagrations are capable of causing extensive injuries and property damage.

Regarding the second issue, there clearly is a danger of asphyxiation and lung damage if one enters a low temperature LNG cloud. Such accidents are not expected to be common events, since the cloud is usually quite visible in the daytime due to condensation of humidity from the air. Furthermore, areas where such cold clouds can accumulate are normally contained within a bund wall or pit surrounding an LNG storage tank, where workers are not routinely present and where the public should not be allowed. However, the possibility of these accidents cannot be discounted; analogous occurrences have been observed in non-LNG facilities. (For example, Medard (1970) describes a 1968 event in France in which semi-trailer truck filled with ammonia ruptured. The release formed a white, mushroom shaped cloud. Six nearby workers went to investigate the noise and were enveloped by the cloud; three collapsed and died.)

Regarding the third issue, material failures have occurred on LNG carrier ships when LNG has spilled on steel deck plates, causing contraction and brittle failure. However, these incidents apparently have not involved widespread damage and have not led to severe consequences (Harris 1993 and Frondeville 1977). It should be noted that the 1944 Cleveland accident was caused by a material failure of the tank wall itself. That grade of steel, containing $3.5 \%$ nickel, is no longer used for LNG tanks; $9 \%$ nickel steel is used instead. This change precludes tank membrane failure by brittle fracture (assuming there are no significant design or manufacturing errors in tank construction).

Regarding the fourth issue, a rapid phase transition is possible if LNG is finely dispersed in a much warmer liquid, such as water at $300^{\circ} \mathrm{K}$. However, the water would have to fall into the LNG or the LNG would have be injected below the water surface. Numerous experiments where LNG has been spilled on the water surface have not resulted in any violent phase transitions. 


\section{CONCLUSIONS AND RECOMMENDATIONS}

\subsection{Study Results}

A number of potentially risk significant refueling station accident scenarios have been identified in this study. These scenarios, listed in Tables 3-4 and 3-5 and summarized in Tables 1-2 and 1-3, are not believed to be likely, due to the relatively low likelihood of some of the initiating events (e.g., relief valves failing open, tank/piping failure due to a severe external event) or to the requirement for multiple failures in the scenario (e.g., an initial error during refueling followed by failure of early recovery efforts). However, based on reports and past events involving LNG or other gaseous vehicle fuels, it appears that these scenarios are not so unlikely as to be incredible. ${ }^{j}$ Designers of new facilities and operators of existing ones need to ensure that their facilities are adequately protected with respect to both scenario initiation and progression.

This study also shows how observed differences in station design, operational practices, and siting can affect the likelihood of different initiating events and safety barrier (top event) failures, thereby affecting station risk. Example differences in design involve the extent and size of bunds for spill containment and the location of maintenance facilities. Some potentially important differences in operations and operational practices involve the frequency of refueling activities, the accessibility of the station to the public, and the emergency response training of vehicle refuelers (drivers or designated staff) and other station personnel. Differences in station siting can affect the likelihood of external hazards to the station as well as the exposure of the public to station accidents.

Finally, this study has reviewed a wide range of documents relevant to LNG safety issues recently raised by Hunt (see Section 4.6). Focusing just on LNG safety, it appears that at least two of these issues (vapor cloud ignition and injuries/fatalities due to exposure to an LNG vapor cloud) are reasonable concerns and need to be addressed in station design, operations, and siting. However, it should be cautioned that this study, being qualitative in nature and focused on LNG, has not addressed the issues of absolute risk (e.g., what is the probability of the events in question) or relative risk (e.g., how does the LNG risk compare with risks from conventional fuels). A quantitative analysis is needed before the true safety significance of these issues can be determined.

\subsection{Recommendations}

The following recommendations are based on the results of this study. They involve: (a) potential design and operational improvements at LNG refueling stations and (b) additional studies that need to be performed to clarify key issues. Regarding the design and operational improvements, it is recommended that:

Improvements be made in procedures and training. Variances in operational practices that may have an impact on safety (e.g., tank venting, use of grounding wires, use of PPE), improper responses to alarms, and the lack of procedures during maintenance (which leads to learning by trial and error) are potentially

j. It should be noted that lessons leamed from major past incidents involving LNG have been used to improve designs and equipment. The investigation following the 1944 Cleveland release and explosions led to the use of steels that would not become brittle at $112^{\circ} \mathrm{K}$ (BOM, 1946). The accident at Cove Point in 1978 led to the rewriting standards for the sealing conduits and for the calibration of methane detectors (Van Meerbeke, 1982). 
important safety issues that need to be addressed. It is useful to observe that improvements in training and procedures are relatively inexpensive means to reduce risk.

Station designs should account for: a) the possibility of LNG leakage along unexpected pathways (e.g., past seals) to enclosed spaces, and b) the possibility of complete LNG inventory losses. Although neither event is likely, they have been historically observed (albeit in different facilities) and prudence dictates that they be addressed. This recommendation implies, for example, the use of methane detectors in all enclosed spaces, designing/backfitting to prevent the buildup of methane in all enclosed spaces (assuming a leak), and the provision of appropriately sized bund walls completely surrounding the main LNG storage tank(s).

The dissemination of best practices among stations should be strongly supported. This recommendation supports the preceding ones, and is driven by the same issues.

The above recommendations are based on field observations at three different LNG refueling stations and on information gathered from a number of papers and reports. Because the stations visited represent a limited sample in terms of design, operational, and siting characteristics, these recommendations must be regarded as being somewhat preliminary. A number of follow-on safety studies are therefore recommended. These studies will validate and modify, as appropriate, the conclusions of this study, and will provide a stronger basis for suggested changes in current practices.

In addition to these safety studies, additional studies regarding key phenomenology during LNG accidents are recommended. These latter studies are needed to more completely address the issues raised in the Hunt memo (Hunt 1996). Moreover, they will provide invaluable support to qualitative and quantitative risk assessment efforts which need better answers to such questions as how large must a spill be to pose a significant hazard offsite.

The particular studies recommended for the near term are as follows.

- $\quad$ Additional visits to a new group of operating refueling stations should be made. Observations from these visits will modify or strengthen current conclusions regarding potential design and operational weak points.

- An in-depth review of LNG accident/event reports (case studies) should be performed to provide a stronger link between experiential data and the failure scenarios identified in the risk assessment. By identifying the observed causes of failure and any sources of dependencies between multiple failures in these case studies, the study will enable an improved assessment of scenario likelihood. The study will also identify failure mechanisms which are less likely or no longer relevant, due to aclvances in codes and standards, construction practices, operational practices, and so forth.

- A detailed review on post-1978 experimental data relevant to predicting LNG hazards. This review, which will identify sources, models, and codes, will provide a more definitive picture of what is known concerning LNG dispersion and ignition behavior under realistic accident conditions. This is needed to determine the risk significance of the two Hunt memo issues of potential concern (i.e., unconfined vapor cloud fires or explosions and direct exposure to LNG vapor). 
Finally, it is recommended that the following two studies be performed as time and resources permit. While they are of lesser urgency than the preceding studies, their results should be very useful to the industry.

- A study should be performed to determine which current safety practices (e.g., use of grounding strap) are truly necessary. For those which are needed, steps should be taken to ensure compliance. This study addresses the possibility that overly conservative requirements may lead to an indiscriminate attitude towards all safety requirements on the part of some drivers and station personnel.

- The qualitative scenarios identified in this report should be quantified for LNG and conventional (gasoline and diesel) refueling stations. Such a risk assessment will allow an improved prioritization of accident scenarios, and will support detailed design and operational trade-offs. It will also provide an improved basis for evaluating the overall safety of LNG fueling stations. 


\section{BASIC DEFINITIONS}

Reflagration Combustion of a gaseous mixture of fuel and oxygen, where the combustion wave front is subsonic.

Detonation Rapid combustion of a fuel-oxygen mixture where the combustion wave front travels at the sonic velocity. Detonations are regarded as much more severe than deflagrations because of the overpressure and rapid liberation of thermal energy.

Geysering Flow surges of a vapor-liquid mixture in vertical tubes caused by heat inleakage and the formation of bubbles within the liquid,

Inerting Filling an enclosed space, such as a tank or room, with a gas that will not support combustion. Nitrogen and argon are examples.

Rollover Delayed, but vigorous mixing of new and old LNG caused by differences in composition and temperature.

Weathering Change in the composition of stored $\mathrm{LNG}$ due to the more rapid vaporization of methane compared with ethane, propane or the higher hydrocarbons 


\section{REFERENCES}

ACGIH, 1996, American Conference of Governmental Industrial Hygienists, 1996 TLVs and BEIs, Threshold Limit Values for Chemical Substances and Physical Agents, and Biological Exposure Indices, ISBN 1-882417-13-5, ACGIH, Cincinnati, Ohio, 1996.

ANS, 1980, American Nuclear Society and the Institute of Electrical and Electronics Engineers, $P R A$ Procedures Guide, a Guide to the Performance of Probabilistic Risk Assessments for Nuclear Power Plants, NUREG/CR-2300, prepared for the U.S. Nuclear Regulatory Commission, January 1983.

ASME, 1995, Risk-Based Inspection-Development of Guidelines, Volume 1: General Document, American Society of Mechanical Engineers, 1991.

ATA, 1995, Recommended Practices for LNG Powered Heavy Duty Trucks, ATA Foundation Alternative Fuels Task Force, The American Trucking Associations Foundation, Inc., 1995.

Baker, 1991, Baker; Wilfred E., and Tang; Ming Jun, Gas, Dust and Hybrid Explosions, Elsevier, Amsterdam, 1991.

BOM, 1946, M. A. Elliot et al., Report on the Investigation of the Fire at the Liquefaction, Storage, and Regasification Plant of the East Ohio Gas Company, Cleveland, Ohio, October 20, 1944, Report of Investigations 3867, Bureau of Mines, Pittsburgh, PA, 1946.

Bull, 1976, Bull, D.C., Elsworth, J. E., Hooper, G., and Quinn, C. P., "A study of spherical detonation in mixtures of methane and oxygen diluted by nitrogen," J. Phys. D, Vol. 9, pp. 1991-2000, 1976.

CGA, 1996, Compressed Gas Association, Accident Prevention in Oxygen-Rich and Oxygen-Deficient Atmospheres, CGA P-14-1992, CGA, Inc., Arlington, VA, 1992.

Chan, 1992, Chan, S.T., "Numerical Simulations of LNG Vapor Dispersion from a Fenced Storage Area," Journal of Hazardous Materials, 30, (1992), 195-224.

Drake, 1973, Drake, Elizabeth M, Geist, J. M., and Smith, K. A., "Prevent LNG 'rollover'," Hydrocarbon Processing, Vol 52, March 1973, pp. 87-90.

Frondeville, 1977, B. de Frondeville, "Reliability and Safety of LNG Shipping: Lessons from Experience," SNAME Transactions, 85, 1977, pp. 459-480.

GAO, 1978, Liquefied Energy Gases Safety, GAO-EMD-78-28, General Accounting Office, Washington DC, July $31,1978$.

Geffen, 1980, C. A. Geffen, An Assessment of the Risk of Transporting Propane by Truck and Train, PNL-3308, Battelle Pacific Northwest Laboratory, March 1980.

GRI, 1994, Gas Research Institute, An Introduction to LNG Vehicle Safety, GRI-92/0465, accession number PB94-176112, March 1994. 
GRI, 1996, Midgett, Dan E. II, Best Available Practices for LNG Fueling of Fleet Vehicles, GRI-96/0180, Gas Research Institute (prepared by the M. W. Kellogg Company, Houston, Texas), February 1996.

Gugan, 1979, K. Gugan, Unconfined Vapor Cloud Explosions, The Institution of Chemical Engineers, 1979.

Harris, 1993, F. S. Harris, "Safety features on LNG Ships," Cryogenics, 33, pp. 772-777, 1993.

Hord, 1978, J. Hord, "Is Hydrogen Safe?" International Journal of Hydrogen Energy, Vol. 3, pp. 157176,1978

Hunt, 1996, P. Hunt, Peter Hunt Associates, 7501 Elba Road, Alexandria, VA 22305, letter to Thomas Grumbly, Assistant Secretary of Energy, October 15, 1996.

IFC, 1980, LNG Facility Accident at Cove Point, Maryland, Committee Print 96-IFC 46, Committee on Interstate and Foreign Commerce, U.S. House of Rep., U. S. Govt. Printing Office, Washington, 1980.

Kaplan and Garrick, 1981, S. Kaplan and B.J. Garrick, "On the Quantitative Definition of Risk," Risk Analysis, 1, pp. 11-37, 1981.

Kazarians, 1997, M. Kazarians, Personal communication with N. Siu, January 1997.

Leone, 1990, F.A. Leone, "Hazard Materials Testing at the U.S. Department of Energy's L:iquefied Gaseous Fuels Spill Test Facility," Plant/Operations Progress, Vol. 9, No. 4, October 1990, pp. 226-230.

Mancini, 1988, R.A. Mancini, "The Use (and Misuse) of Bonding for Control of Static Ignition Hazards," Plant/Operations Progress, 7, No. 1, January 1988, pp. 23-31.

Medard, 1970, L. Medard, "Rupture of an Ammonia Road Tanker," Ammonia Plant Safety and Related Facilities, 12, American Institute of Chemical Engineers, 1970, pp. 17-18.

Melchers and Feutrill, 1995,.R. E. Melchers and W. R. Feutrill, "Risk Assessment for Automotive LPG Facilities," in Risk and Safety Assessments: Where Is the Balance?, PVP-Vol. 296, SERA-Vol. 3, American Society of Mechanical Engineers, 1995, pp. 457-462.

Morioka, 1986, Morioka, Mikio; Obama, Toshio; Kouda, Yasuo; Mori, Mikio; Tomura, S. and Shintaro, E., "Simulation of the Geysering Phenomenon in LNG Pipes," in Advances in Cryogenic Engineering, Vol 31, R. W. Fast, ed., Plenum Press, New York, 1986, pp. 1111-1119.

Mulliner, 1974, Mulliner, David K., "Now - A Practical Method For Odorizing LNG," Pipeline and Gas Journal, Vol. 201, June 1974, pp. 78-84.

NGV, 1996, "'LNG Safety Performance about Same as Diesel' Say Experienced Fleet Managers, " LNG Express, August 1996, pp.. 6-8. 
Ong, 1985, Ong, Han, I., "Development of LNG Facilities Safety Standards," Bulletin of the Association of Engineering Geologists, Vol. XXII, No. 1, Feb. 1985, pp. 25-38.

OSHA, 1996, U.S. Code of Federal Regulations, Title 29,Labor, Part 29CFR1917.23, Hazardous Atmospheres and Substances, July 1996, and 30CFR57.5015, July 1996.

PAR, 1980,.Pipeline Accident Report: Columbia Liquefied Natural Gas Corporation Explosion and Fire, Cove Point Maryland, October 6, 1979, NTSB-PAR-80-2, National Transportation Safety Board, April 16, 1980.

Pentz ,1995, Pentz, Russell, "Liquified Natural Gas Experience of a Large Transit Fleet," American Energy Week '95 Conference and Exhibition, Jan 31-Feb. 2, 1995, Houston, TX, Book 3, Alternative Fuel Vehicles '95.

Puttock, 1982, Puttock, J. S., Blackmore, D. R., and Colenbrander, G. W., "Field Experiments on Dense Gas Dispersion," Journal of Hazardous Materials, 6 (1982) 13-41.

Rhoads, 1978, R. E. Rhoads, An Assessment of the Risk of Transporting Gasoline by Truck, PNL-2133, Battelle Pacific Northwest Laboratory, November 1978.

SAIC, 1990, D. M. Friedman et al., Risk Assessment of Indoor Refueling and Servicing of CNG-fueled Mass Transit Buses, GRI-90/0191, Gas Research Institute and Science Applications International Corporation, accession number PB91-161364, August 1990.

Siu et al., 1995, N. O. Siu et al., Evaluating Risk Assessment Approaches in Oil Spill Prevention Applications, INEL-95/0401, Idaho National Engineering Laboratory, August 1995.

Shah, 1974, Shah, J. M., and Aarts, J. J., "Effect of Weathering of LNG in Storage Tanks," in Advances in Cryogenic Engineering, Vol 19, K. D. Timmerhaus, ed., Plenum Press, New York, 1974, pp. 253-260.

Thomas, 1996, Thomas, Theodore A., INEL, private communication concerning design of INEL bus maintenance facility, October 17, 1996.

Thomson, 1987, Thomson, J. R., EngineeringSafety Assessment, An Introduction, Chapter 5, Major Industrial Hazards, Longman Scientific and Technical, London, 1987.

USNRC, 1975, U.S. Nuclear Regulatory Commission, Reactor Safety Study, An Assessment of Accident Risks in Commercial Nuclear Power Plants, NUREG-75/014, WASH-1400, October 1975.

Van Horn and Wilson, 1977,.A. J. Van Horn and R. Wilson, "The Potential Risks of Liquefied Natural Gas," Energy, 2, 1977, pp. 375-389.

Van Meerbeke, 1982, Van Meerbeke, R. C., "Accident At the Cove Point LNG Facility," Chemical Engineering Progress, January 1982, pp. 39-45.

Welker and Schorr, 1979, J. R. Welker and H. P. Schorr, "LNG Plant Experience Data Base," paper 79-T-21, American Gas Association Transmission Conference, May 21-23, 1979, New Orleans, LA, pp. T-263 to T-266. 
Williamson and Edeskuty, 1983, K. D. Williamson, Jr., and F. J. Edeskuty, Liquid Cryogens, CRC Press, Boca Raton, FL, 1983.

Zabetakis, 1967,.M. G. Zabetakis, Safety with Cryogenic Fluids, Plenum Press, New York, 1967. 


\section{Appendix A - Failure Modes and Effects Analysis for Facility Number 1}

This appendix contains a Failure Modes and Effects Analysis (FMEA) performed for the Facility 1 fuel dispensing system. The analysis considers each component and postulates the system effects or responses to the various ways in which the component could fail. The FMEA provides some insights into the failure modes and behavior of the components in the system.

There are many valves in the system, including over 30 manual valves, 12 relief valves, 3 check valves, and 5 flow control valves. The FMEA shows that these valves, which constitute about two-thirds of the system components are only a safety concern if the failure mode is external leakage or relief valve venting. LNG valve data must be reviewed to determine if external leakage (i.e., stem leakage or valve body cracking) are frequent events that warrant attention.

The other components include rupture disks, instruments, fill connections, the pump and meter, and the tanks. Instruments could be a source of concern if they leak at penetrations or leak from instrument taps, or give false indications. The connection lines appear to be benign, used infrequently and provided with isolation valves. Any pump and meter failures require the opening of the pressure tank for repair or replacement, but do not appear to pose safety concerns.

In general, most of the failures hypothesized in the FMEA result in the inability of the system to deliver fuel to vehicles or to receive incoming fuel shipments. While this downtime is an operational inconvenience, it is not a safety concern. Catastrophic events, such as pump impeller catastrophic failure followed by impeller debris piercing the pressure tank wall, were not considered because this is not a typical failure mode for a centrifugal pump. The system analyzed is not very complex and has little automated control.

One insight from the FMEA is that there are a number of single point failures that can lead to a release of LNG. In particular, the pressure relief valves for the storage and pressure tanks are single barriers between the LNG and the atmosphere. These relief valves are vented up the facility stack (which helps to loft the gas for dispersion); any failure of these valves is a single failure leading to a release. For example, a valve might successfully open to relieve a mild system overpressure, but then fail in the open position (e.g., due to buildup of ice from atmospheric humidity). As a second problem, if the valves are not well insulated, ice could build up on them while they are closed, causing them to remain closed when they are demanded to open. This could also be true for the rupture disks. Relief valve failure rates tend to be low (on the order of $10^{-4}$ to $10^{-3}$ per demand) but there are several of these valves in the fuel dispensing system.

A second insight concerns the degree of redundancy provided by the standard doublewalled storage tank construction. If air or LNG leaks into the vacuum space between the two walls, a heat transfer path will be provided to the inner tank. Without mitigative action, eventually the LNG in the tank will boil and vent. (This problem is well-recognized; tanks must typically be refurbished in 5 to 7 years.) Furthermore, the outer vessel walls are generally constructed of carbon steel to reduce the cost of the tank, and so are susceptible to brittle fracture if cooled to LNG temperatures. Thus, a failure of the inner vessel will lead to a release of LNG into the vacuum space which, in turn, can lead to failure of outer vessel. The double wall does not mean double containment in the case of cryogens. 


\section{Appendices}

\section{APPENDIX A - Failure Modes and Effects Analysis for Facility Number 1}

Table A-1 Failure Modes and Effects Analysis

Liquefied Natural Gas fill station, Idaho National Engineering Laboratory Central Facilities Area

\begin{tabular}{|c|c|c|c|c|c|c|}
\hline $\begin{array}{l}\text { Component } \\
\text { identifier }\end{array}$ & $\begin{array}{l}\text { Component } \\
\text { title }\end{array}$ & $\begin{array}{l}\text { Component } \\
\text { function }\end{array}$ & $\begin{array}{l}\text { Component } \\
\text { failure modes }\end{array}$ & Potential causes & System effects & $\begin{array}{l}\text { Possible } \\
\text { mitigative or } \\
\text { corrective } \\
\text { actions } \\
\end{array}$ \\
\hline FCV-103 & $\begin{array}{l}\text { pump inlet valve } \\
\text { NO }\end{array}$ & $\begin{array}{l}\text { controls storage } \\
\text { tank flow to } \\
\text { pressure tank }\end{array}$ & $\begin{array}{l}\text { Fail to transfer } \\
\text { position } \\
\text { (fail as is) } \\
\text { Fails to remain } \\
\text { open/plugs } \\
\text { External leak } \\
\text { Fail to control flow }\end{array}$ & $\begin{array}{l}\text { bad signal, } \\
\text { mechanical fault, } \\
\text { or environment } \\
\text { condition of the } \\
\text { valve (ice) } \\
\text { mechanical fault } \\
\text { loss of power? } \\
\text { foreign material } \\
\text { stem leak } \\
\text { valve body crack } \\
\\
\text { bad signal, } \\
\text { mechanical fault, or } \\
\text { ice buildup } \\
\end{array}$ & $\begin{array}{l}\text { Lose flow from } \\
\text { storage tank to } \\
\text { pressure tank. } \\
\text { Cannot pump LNG } \\
\text { on demand. } \\
\text { Depressurization } \\
\text { of pump inlet line, } \\
\text { release gas to } \\
\text { environment } \\
\text { Flow may decrease } \\
\text { or increase, } \\
\text { pressure may } \\
\text { fluctuate }\end{array}$ & $\begin{array}{l}\text { initial choice of } \\
\text { valve, routine } \\
\text { inspection and } \\
\text { preventive } \\
\text { maintenance } \\
\text { inspect and } \\
\text { maintain } \\
\text { Sensors to detect } \\
\text { gas release } \\
\text { monitor pressure in } \\
\text { both tanks }\end{array}$ \\
\hline & $\mathrm{NC}=\mathrm{Nor}$ & & & & & \\
\hline
\end{tabular}




\begin{tabular}{|c|c|c|c|c|c|c|}
\hline FCV-104 & $\begin{array}{l}\text { pump vent valve } \\
\text { NO }\end{array}$ & $\begin{array}{l}\text { controls gas vent } \\
\text { flow from pressure } \\
\text { tank ullage to } \\
\text { storage tank ullage }\end{array}$ & \begin{tabular}{|l|}
$\begin{array}{l}\text { Fail to transfer } \\
\text { position } \\
\text { (fail as is) } \\
\text { Fails to remain } \\
\text { open/plugs }\end{array}$ \\
External leak \\
Fail to control flow
\end{tabular} & \begin{tabular}{|l|} 
bad signal, \\
mechanical fault, \\
or environment \\
condition of the \\
valve (ice) \\
mechanical fault \\
loss of power? \\
foreign material \\
\\
stem leak \\
valve body crack \\
\\
bad signal, \\
mechanical fault, or \\
ice buildup \\
\end{tabular} & $\begin{array}{l}\text { Lose flow from } \\
\text { pressure tank ullage } \\
\text { to storage tank } \\
\text { ullage. } \\
\text { Cannot flow } \\
\text { gaseous NG back } \\
\text { to storage tank, P } \\
\text { increase in PT. } \\
\text { Depressurization } \\
\text { of PT ullage line, } \\
\text { release gas to } \\
\text { environment } \\
\text { Flow may decrease } \\
\text { or increase, } \\
\text { pressure may } \\
\text { fluctuate }\end{array}$ & $\begin{array}{l}\text { initial choice of } \\
\text { valve, routine } \\
\text { inspection and } \\
\text { preventive } \\
\text { maintenance } \\
\text { inspect and } \\
\text { maintain } \\
\\
\text { Sensors to detect } \\
\text { gas release } \\
\text { monitor pressure in } \\
\text { both tanks }\end{array}$ \\
\hline FCV-105 & $\begin{array}{l}\text { recirculation valve } \\
\text { NO }\end{array}$ & $\begin{array}{l}\text { controls } \\
\text { recirculation flow } \\
\text { to the storage tank }\end{array}$ & \begin{tabular}{|l|}
$\begin{array}{l}\text { Fail to transfer } \\
\text { position } \\
\text { (fail as is) }\end{array}$ \\
Fails to remain \\
open/plugs \\
External leak \\
Fail to control flow
\end{tabular} & $\begin{array}{l}\text { bad signal, } \\
\text { mechanical fault, } \\
\text { or environment } \\
\text { condition of the } \\
\text { valve (ice) } \\
\text { mechanical fault } \\
\text { loss of power? } \\
\text { foreign material } \\
\text { stem leak } \\
\text { valve body crack } \\
\\
\text { bad signal, } \\
\text { mechanical fault, or } \\
\text { ice buildup }\end{array}$ & $\begin{array}{l}\text { Lose saturation } \\
\text { flow from pressure } \\
\text { tank to storage } \\
\text { tank. } \\
\text { Cannot flow } \\
\text { saturated LNG back } \\
\text { to storage tank, P } \\
\text { increase in PT. } \\
\text { Depressurization } \\
\text { of PT, release LNG } \\
\text { and gas to } \\
\text { environment } \\
\text { Flow may decrease } \\
\text { or increase, } \\
\text { pressure may } \\
\text { fluctuate }\end{array}$ & $\begin{array}{l}\text { Sensors to detect } \\
\text { gas release } \\
\text { monitor pressure in } \\
\text { both tanks }\end{array}$ \\
\hline
\end{tabular}




\begin{tabular}{|c|c|c|c|c|c|c|}
\hline FCV-106 & $\begin{array}{l}\text { saturation coil feed } \\
\text { valve } \\
\text { NO }\end{array}$ & $\begin{array}{l}\text { controls flow routed } \\
\text { from pressure tank } \\
\text { through warming } \\
\text { coils and back to } \\
\text { the storage tank }\end{array}$ & \begin{tabular}{|l|}
$\begin{array}{l}\text { Fail to transfer } \\
\text { position } \\
\text { (fail as is) }\end{array}$ \\
Fails to remain \\
open/plugs \\
External leak \\
Fail to control flow
\end{tabular} & $\begin{array}{l}\text { bad signal, } \\
\text { mechanical fault, } \\
\text { or environment } \\
\text { condition of the } \\
\text { valve (ice) } \\
\text { mechanical fault } \\
\text { loss of power? } \\
\text { foreign material } \\
\text { stem leak } \\
\text { valve body crack } \\
\\
\text { bad signal, } \\
\text { mechanical fault, or } \\
\text { ice buildup }\end{array}$ & $\begin{array}{l}\text { Lose flow from } \\
\text { pressure tank to } \\
\text { storage tank. } \\
\\
\text { Cannot flow LNG } \\
\text { back to storage } \\
\text { tank, P increase in } \\
\text { PT. } \\
\\
\text { Depressurization } \\
\text { of PT ullage line, } \\
\text { release gas to } \\
\text { cinvironimienit } \\
\text { Flow may decrease } \\
\text { or increase, } \\
\text { pressure may } \\
\text { fluctuate }\end{array}$ & $\begin{array}{l}\text { initial choice of } \\
\text { valve, routine } \\
\text { inspection and } \\
\text { preventive } \\
\text { maintenance } \\
\text { inspect and } \\
\text { maintain } \\
\text { Sensors to detect } \\
\text { gas release } \\
\text { monitor pressure in } \\
\text { both tanks }\end{array}$ \\
\hline FCV-107 & $\begin{array}{l}\text { dispensing valve } \\
\mathrm{NC}\end{array}$ & $\begin{array}{l}\text { controls flow to end } \\
\text { use vehicle fill line } \\
\text { TH-1 }\end{array}$ & \begin{tabular}{|l|}
$\begin{array}{l}\text { Fail to transfer } \\
\text { position } \\
\text { (fail as is) }\end{array}$ \\
Fails to remain \\
open/plugs \\
External leak \\
Fail to control flow
\end{tabular} & $\begin{array}{l}\text { bad signal, } \\
\text { mechanical fault, } \\
\text { or environment } \\
\text { condition of the } \\
\text { valve (ice) } \\
\text { mechanical fault } \\
\text { loss of power? } \\
\text { foreign material } \\
\\
\text { stem leak } \\
\text { valve body crack } \\
\\
\text { bad signal, } \\
\text { mechanical fault, or } \\
\text { ice buildup }\end{array}$ & $\begin{array}{l}\text { No flow from } \\
\text { pressure tank to fill } \\
\text { line. } \\
\text { Cannot flow LNG } \\
\text { to transfer line TH- } \\
1, \text { P may increase } \\
\text { in PT. } \\
\text { Depressurization } \\
\text { of Pressure tank, } \\
\text { release gas to } \\
\text { environment } \\
\text { Flow may decrease } \\
\text { or increase, } \\
\text { pressure may } \\
\text { fluctuate }\end{array}$ & $\begin{array}{l}\text { initial choice of } \\
\text { valve, routine } \\
\text { inspection and } \\
\text { preventive } \\
\text { maintenance } \\
\text { inspect and } \\
\text { maintain } \\
\text { Sensors to detect } \\
\text { gas release } \\
\text { monitor pressure in } \\
\text { both tanks }\end{array}$ \\
\hline
\end{tabular}




\begin{tabular}{|c|c|c|c|c|c|c|}
\hline V-1 & $\begin{array}{l}\text { top fill valve } \\
\text { NC }\end{array}$ & \begin{tabular}{|l} 
shut off valve for \\
storage tank top fill \\
from tanker, part of \\
double block \\
valving with V-30
\end{tabular} & $\begin{array}{l}\text { Fail to open } \\
\text { External leak } \\
\text { Internal leak }\end{array}$ & $\begin{array}{l}\text { mechanical fault } \\
\text { (jammed) } \\
\text { ice buildup } \\
\text { stem leak } \\
\text { valve body crack } \\
\text { seat scored } \\
\text { ice buildup }\end{array}$ & $\begin{array}{l}\text { cannot top fill the } \\
\text { storage tank } \\
\text { release gas to } \\
\text { environment } \\
\text { allow foreign } \\
\text { material intrusion } \\
\text { into fill line }\end{array}$ & $\begin{array}{l}\text { repair is required } \\
\text { sensors to detect } \\
\text { gas release } \\
\text { inspect and } \\
\text { maintain }\end{array}$ \\
\hline $\mathrm{V}-2$ & $\begin{array}{l}\text { hose drain valve } \\
\mathrm{NC}\end{array}$ & $\begin{array}{l}\text { shut off valve to } \\
\text { stack for tanker } \\
\text { hose venting }\end{array}$ & $\begin{array}{l}\text { Fail to open } \\
\text { External leak } \\
\text { Internal leak }\end{array}$ & $\begin{array}{l}\text { mechanical fault } \\
\text { (jammed) } \\
\text { ice buildup } \\
\text { stem leak } \\
\text { valve body crack } \\
\\
\text { seat scored } \\
\text { ice buildup }\end{array}$ & $\begin{array}{l}\text { cannot vent hose } \\
\text { line, must rely on } \\
\text { PSV-104A } \\
\text { release gas to } \\
\text { environment at } \\
\text { ground level, not } \\
\text { up stack } \\
\text { losing LNG up the } \\
\text { stack instead of } \\
\text { going to storage } \\
\text { tank }\end{array}$ & $\begin{array}{l}\begin{array}{l}\text { inspect and } \\
\text { maintain }\end{array} \\
\text { sensors detect gas } \\
\text { release } \\
\\
\text { metering on tank } \\
\text { truck should } \\
\text { provide warning } \\
\text { that there is } \\
\text { leakage, vent noise } \\
\text { also is a warning of } \\
\text { leakage } \\
\end{array}$ \\
\hline $\mathrm{V}-8$ & $\begin{array}{l}\text { liquid phase valve } \\
\text { NO }\end{array}$ & $\begin{array}{l}\text { shut off valve for } \\
\text { instruments } \\
\text { monitoring storage } \\
\text { LNG }\end{array}$ & $\begin{array}{l}\text { Fail to remain } \\
\text { open/plugs } \\
\text { External leak }\end{array}$ & $\begin{array}{l}\text { mechanical fault } \\
\text { ice buildup } \\
\\
\text { steam leak } \\
\text { valve body crack }\end{array}$ & $\begin{array}{l}\text { Lose LNG flow to } \\
\text { pressure and } \\
\text { differential pressure } \\
\text { instruments } \\
\text { release LNG to } \\
\text { environment at } \\
\text { ground level, not } \\
\text { up stack }\end{array}$ & $\begin{array}{l}\text { Alarms on pressure } \\
\text { indicators will alert } \\
\text { operators to loss of } \\
\text { flow } \\
\text { sensors detect } \\
\text { LNG/gas release }\end{array}$ \\
\hline
\end{tabular}




\begin{tabular}{|c|c|c|c|c|c|c|}
\hline V-9 & $\begin{array}{l}\text { vapor phase valve } \\
\text { NO }\end{array}$ & \begin{tabular}{|l|} 
shut off valve for \\
instruments \\
monitoring gaseous \\
NG in storage tank
\end{tabular} & $\begin{array}{l}\text { Fail to remain } \\
\text { open/plugs } \\
\text { External leak }\end{array}$ & $\begin{array}{l}\text { mechanical fault } \\
\text { jce buildup } \\
\text { steam leak } \\
\text { valve body crack }\end{array}$ & \begin{tabular}{|l|} 
Lose gas flow to \\
pressure and \\
differential pressure \\
instruments \\
release gas to \\
environment at \\
ground level, not \\
up stack
\end{tabular} & $\begin{array}{l}\text { Alarms on pressure } \\
\text { indicators will alert } \\
\text { operators to loss of } \\
\text { flow } \\
\text { sensors detect gas } \\
\text { release }\end{array}$ \\
\hline $\mathrm{V}-10$ & $\begin{array}{l}\text { LI-1 equalization } \\
\text { valve } \\
\text { NO }\end{array}$ & $\begin{array}{l}\text { valve that balances } \\
\text { inputs to pressure } \\
\text { and differential } \\
\text { pressure indicators } \\
\text { so they will } \\
\text { indicate storage } \\
\text { tank level }\end{array}$ & $\begin{array}{l}\text { Fail to remain } \\
\text { open/plugs } \\
\text { External leak }\end{array}$ & $\begin{array}{l}\text { mechanical fault } \\
\text { ice buildup } \\
\text { stem leak } \\
\text { valve body crack }\end{array}$ & $\begin{array}{l}\text { Creates erroneous } \\
\text { readings in P and } \\
\text { DP instruments } \\
\text { release gas to } \\
\text { environment at } \\
\text { ground level, not } \\
\text { up stack }\end{array}$ & $\begin{array}{l}\text { Alarms on pressure } \\
\text { indicators may alert } \\
\text { operators to loss of } \\
\text { flow } \\
\text { sensors detect gas } \\
\text { release }\end{array}$ \\
\hline $\mathrm{V}-11$ & $\begin{array}{l}\text { full trycock valve } \\
\text { NC }\end{array}$ & $\begin{array}{l}\text { valve to manually } \\
\text { verify calibration } \\
\text { liquid level in } \\
\text { storage tank, used } \\
\text { infrequently } \\
\text { (1/year?) }\end{array}$ & 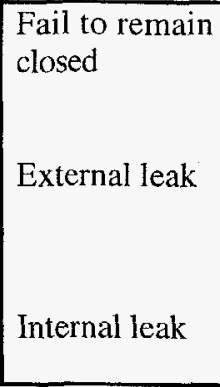 & $\begin{array}{l}\text { mechanical fault } \\
\text { stem leak } \\
\text { valve body crack } \\
\text { valve seat scored }\end{array}$ & $\begin{array}{l}\text { Large gas/LNG } \\
\text { leak at ground level } \\
\text { Small gas/LNG } \\
\text { leak at ground level } \\
\text { Small gas/LNG } \\
\text { leak at ground level }\end{array}$ & $\begin{array}{l}\text { sensors detect } \\
\text { gas/LNG release } \\
\text { sensors detect } \\
\text { gas/LNG release } \\
\\
\text { sensors detect } \\
\text { gas/LNG release }\end{array}$ \\
\hline
\end{tabular}




\begin{tabular}{|c|c|c|c|c|c|c|}
\hline $\mathrm{V}-12$ & $\begin{array}{l}\text { manual vent valve } \\
\mathrm{NC}\end{array}$ & $\begin{array}{l}\text { valve to vent } \\
\text { gaseous NG from } \\
\text { storage tank to the } \\
\text { stack }\end{array}$ & $\begin{array}{l}\text { Fail to remain } \\
\text { closed } \\
\text { External leak } \\
\text { Internal leak }\end{array}$ & $\begin{array}{l}\text { mechanical fault } \\
\text { stem leak } \\
\text { valve body crack } \\
\text { scored valve seat }\end{array}$ & $\begin{array}{l}\text { Vents gas from the } \\
\text { storage tank to the } \\
\text { stack } \\
\text { vents gas from } \\
\text { storage tank to } \\
\text { environment as } \\
\text { ground level release } \\
\text { Vents small gas } \\
\text { quantities from the } \\
\text { storage tank to the } \\
\text { stack }\end{array}$ & $\begin{array}{l}\text { Tank instruments } \\
\text { will note loss of } \\
\text { inventory and alarm } \\
\text { sensors detect gas } \\
\text { release } \\
\\
\text { may only be } \\
\text { noticed by viewing } \\
\text { stack emissions, } \\
\text { inventory loss may } \\
\text { be thought to be } \\
\text { part of normal } \\
\text { effluent }\end{array}$ \\
\hline$V-13$ & $\begin{array}{l}\text { pump inlet } \\
\text { isolation valve } \\
\mathrm{NO}\end{array}$ & $\begin{array}{l}\text { isolation of storage } \\
\text { tank flow to pump } \\
\text { in pressure tank }\end{array}$ & $\begin{array}{l}\text { Fails to remain } \\
\text { open/plugs } \\
\text { External leak }\end{array}$ & $\begin{array}{l}\text { mechanical fault } \\
\text { foreign material } \\
\text { buildup } \\
\text { stem leak } \\
\text { valve body crack }\end{array}$ & $\begin{array}{l}\text { Cannot pump LNG } \\
\text { on demand. } \\
\text { Depressurization } \\
\text { of pump inlet line, } \\
\text { release gas to } \\
\text { environment }\end{array}$ & $\begin{array}{l}\begin{array}{l}\text { inspect and } \\
\text { maintain }\end{array} \\
\text { Sensors to detect } \\
\text { gas release }\end{array}$ \\
\hline$\overline{V-14}$ & $\begin{array}{l}\text { pump vent } \\
\text { isolation valve } \\
\text { NO }\end{array}$ & $\begin{array}{l}\text { isolation of } \\
\text { pressure tank } \\
\text { gaseous NG vent to } \\
\text { storage tank ullage }\end{array}$ & $\begin{array}{l}\text { Fails to remain } \\
\text { open/plugs } \\
\text { External leak }\end{array}$ & $\begin{array}{l}\text { mechanical fault } \\
\text { foreign material } \\
\text { buildup } \\
\\
\text { stem leak } \\
\text { valve body crack }\end{array}$ & $\begin{array}{l}\text { Cannot pump LNG } \\
\text { on demand, } \\
\text { pressure in system } \\
\text { cannot equalize. } \\
\\
\text { Depressurization } \\
\text { of pump outlet } \\
\text { line, release gas to } \\
\text { environment }\end{array}$ & \begin{tabular}{|l|} 
inspect and \\
maintain \\
\\
$\begin{array}{l}\text { Sensors to detect } \\
\text { gas release }\end{array}$ \\
\end{tabular} \\
\hline
\end{tabular}




\begin{tabular}{|c|c|c|c|c|c|c|}
\hline $\mathrm{V}-15$ & $\begin{array}{l}\text { saturation isolation } \\
\text { valve } \\
\text { NO }\end{array}$ & $\begin{array}{l}\text { isolation of } \\
\text { saturated LNG } \\
\text { return to storage } \\
\text { tank }\end{array}$ & $\begin{array}{l}\text { Fails to remain } \\
\text { open/plugs } \\
\text { External leak }\end{array}$ & $\begin{array}{l}\text { mechanical fault } \\
\text { foreign material } \\
\text { buildup } \\
\\
\text { stem leak } \\
\text { valve body crack }\end{array}$ & $\begin{array}{l}\text { Cannot pump LNG } \\
\text { on demand, } \\
\text { pressure in system } \\
\text { cannot equalize. } \\
\text { Depressurization } \\
\text { of pump outlet } \\
\text { line, release gas to } \\
\text { environment }\end{array}$ & $\begin{array}{l}\text { inspect and } \\
\text { maintain } \\
\\
\text { Sensors to detect } \\
\text { gas release }\end{array}$ \\
\hline$V-16$ & $\begin{array}{l}\text { saturation pressure } \\
\text { valve } \\
\text { NC }\end{array}$ & $\begin{array}{l}\text { vent valve for liquid } \\
\text { pressure sensors in } \\
\text { storage tank }\end{array}$ & $\begin{array}{l}\begin{array}{l}\text { Fail to remain } \\
\text { closed }\end{array} \\
\text { External leak } \\
\text { Internal leak }\end{array}$ & $\begin{array}{l}\text { mechanical fault } \\
\text { stem leak } \\
\text { valve body crack } \\
\text { scored valve seat }\end{array}$ & $\begin{array}{l}\text { Vents LNG from } \\
\text { the storage tank to } \\
\text { the stack } \\
\text { vents LNG from } \\
\text { storage tank to } \\
\text { environment as } \\
\text { ground level release } \\
\text { Vents small LNG } \\
\text { quantities from the } \\
\text { storage tank to the } \\
\text { stack }\end{array}$ & \begin{tabular}{|l} 
Tank instruments \\
will note loss of \\
inventory and alarm \\
scinsors detect gas \\
release \\
\\
may only be \\
noticed by viewing \\
stack emissions, \\
inventory loss may \\
be thought to be \\
part of normal \\
effluent
\end{tabular} \\
\hline
\end{tabular}




\begin{tabular}{|c|c|c|c|c|c|c|}
\hline V-17 & $\begin{array}{l}\text { pump sump } \\
\text { manual vent valve } \\
\text { NC }\end{array}$ & $\begin{array}{l}\text { valve to vent } \\
\text { gaseous NG to } \\
\text { stack from ullage of } \\
\text { pressure tank }\end{array}$ & $\begin{array}{l}\text { Fail to remain } \\
\text { closed } \\
\text { External leak } \\
\text { Internal leak }\end{array}$ & $\begin{array}{l}\text { mechanical fault } \\
\text { stem leak } \\
\text { valve body crack } \\
\text { scored valve seat }\end{array}$ & $\begin{array}{l}\text { Vents gas from the } \\
\text { pressure tank to the } \\
\text { stack } \\
\text { vents gas from } \\
\text { pressure tank to } \\
\text { environment as } \\
\text { ground level release } \\
\text { Vents small gas } \\
\text { quantities from the } \\
\text { pressure tank to the } \\
\text { stack }\end{array}$ & \begin{tabular}{|l} 
Tank instruments \\
will note loss of \\
inventory and alarm \\
sensors detect gas \\
release \\
\\
may only be \\
noticed by viewing \\
stack emissions, \\
inventory loss may \\
be thought to be \\
part of normal \\
effluent
\end{tabular} \\
\hline V-18 & $\begin{array}{l}\text { dispensing drain } \\
\text { valve } \\
\text { NC }\end{array}$ & $\begin{array}{l}\text { valve to vent } \\
\text { gaseous NG to } \\
\text { stack from fill line } \\
\text { TH-1 }\end{array}$ & $\begin{array}{l}\text { Fail to remain } \\
\text { closed } \\
\text { External leak } \\
\text { Internal leak }\end{array}$ & $\begin{array}{l}\text { mechanical fault } \\
\text { stem leak } \\
\text { valve body crack } \\
\text { scored valve seat }\end{array}$ & $\begin{array}{l}\text { Vents gas from the } \\
\text { transfer hose } \\
\text { volume to the stack } \\
\text { vents gas from the } \\
\text { transfer hose } \\
\text { volume to the } \\
\text { environment as a } \\
\text { ground level release } \\
\text { Vents small gas } \\
\text { quantities from the } \\
\text { TH-1 to the stack }\end{array}$ & $\begin{array}{l}\text { Tank instruments } \\
\text { will note loss of } \\
\text { inventory and alarm } \\
\text { sensors detect gas } \\
\text { release } \\
\text { may only be } \\
\text { noticed by viewing } \\
\text { stack emissions, } \\
\text { inventory loss may } \\
\text { be thought to be } \\
\text { part of normal } \\
\text { effluent }\end{array}$ \\
\hline
\end{tabular}




\begin{tabular}{|c|c|c|c|c|c|c|}
\hline $\mathrm{V}-19$ & $\begin{array}{l}\text { vacuum gauge tube } \\
\text { valve } \\
\text { NO }\end{array}$ & $\begin{array}{l}\text { shut off valve to } \\
\text { storage tank } \\
\text { annulus vacuum } \\
\text { gauge }\end{array}$ & $\begin{array}{l}\text { Fail to remain } \\
\text { open/plugs } \\
\text { External leak }\end{array}$ & $\begin{array}{l}\text { mechanical fault } \\
\text { ice buildup } \\
\text { stem leak } \\
\text { valve body crack }\end{array}$ & $\begin{array}{l}\begin{array}{l}\text { Lose vacuum } \\
\text { reading on storage } \\
\text { tank }\end{array} \\
\text { releases LNG from } \\
\text { storage tank to } \\
\text { environment as } \\
\text { ground level release }\end{array}$ & $\begin{array}{l}\text { Alarm on vacuum } \\
\text { value? } \\
\text { sensors detect } \\
\text { LNG/gas release }\end{array}$ \\
\hline $\mathrm{V}-20$ & $\begin{array}{l}\text { safety selector } \\
\text { valve } \\
\text { NO, aligned to } \\
\text { PSV-101A and } \\
\text { PSE-101A }\end{array}$ & $\begin{array}{l}\text { Valve to route } \\
\text { storage tank } \\
\text { effluent to sets of } \\
\text { relief valves and } \\
\text { rupture disks }\end{array}$ & $\begin{array}{l}\text { Fails to remain } \\
\text { open } \\
\text { Fails to open } \\
\text { secondary line }\end{array}$ & $\begin{array}{l}\text { mechanical fault } \\
\text { ice buildup } \\
\text { mechanical fault } \\
\text { ice buildup }\end{array}$ & $\begin{array}{l}\text { Safety equipment, } \\
\text { may not know of } \\
\text { fault until an } \\
\text { accident event } \\
\text { occurs }\end{array}$ & $\begin{array}{l}\text { regular testing and } \\
\text { inspections }\end{array}$ \\
\hline$V-21$ & $\begin{array}{l}\text { evacuation valve } \\
\mathrm{NC}\end{array}$ & $\begin{array}{l}\text { Shut off valve to } \\
\text { storage tank } \\
\text { annulus, used to } \\
\text { draw fresh vacuum } \\
\text { on annulus. } \\
\text { Infrequently used } \\
\text { (1/yr?) }\end{array}$ & $\begin{array}{l}\text { Fail to remain } \\
\text { closed } \\
\text { Internal leak }\end{array}$ & $\begin{array}{l}\text { mechanical fault } \\
\text { valve seat leaks by }\end{array}$ & $\begin{array}{l}\text { Large air ingress to } \\
\text { storage tank } \\
\text { annulus, will boil } \\
\text { LNG as heat } \\
\text { transfers } \\
\text { Cannot maintain } \\
\text { proper vacuum, } \\
\text { boiloff rate slowly } \\
\text { rises for storage } \\
\text { tank }\end{array}$ & $\begin{array}{l}\text { regular testing and } \\
\text { inspection } \\
\text { Monitoring } \\
\text { vacuum with TC-1 }\end{array}$ \\
\hline $\mathrm{V}-22$ & $\begin{array}{l}\text { stack drain valve } \\
\mathrm{NC}\end{array}$ & $\begin{array}{l}\text { valve to drain any } \\
\text { liquid that } \\
\text { accumulates in the } \\
\text { vent stack }\end{array}$ & $\begin{array}{l}\text { Fails to remain } \\
\text { closed } \\
\text { Internal leak } \\
\text { External leak }\end{array}$ & $\begin{array}{l}\text { mechanical fault } \\
\text { valve seat scored } \\
\\
\text { valve stem leak } \\
\text { valve body crack }\end{array}$ & $\begin{array}{l}\text { could vent to } \\
\text { ground instead of } \\
\text { up stack during } \\
\text { accident } \\
\text { small leak at } \\
\text { ground level during } \\
\text { accident } \\
\text { small leak at } \\
\text { ground level during } \\
\text { accident }\end{array}$ & $\begin{array}{l}\text { inspect and } \\
\text { maintain } \\
\text { inspect and } \\
\text { maintain } \\
\text { inspect and } \\
\text { maintain }\end{array}$ \\
\hline
\end{tabular}




\begin{tabular}{|c|c|c|c|c|c|c|}
\hline $\mathrm{V}-23$ & $\begin{array}{l}\text { auxiliary top fill } \\
\text { valve } \\
\mathrm{NC}\end{array}$ & $\begin{array}{l}\text { second valving path } \\
\text { for tanker to refill } \\
\text { storage tank using } \\
\text { FC-1 }\end{array}$ & $\begin{array}{l}\text { Fails to remain } \\
\text { closed } \\
\text { Internal leak } \\
\text { External leak }\end{array}$ & $\begin{array}{l}\text { mechanical fault } \\
\text { valve seat scored } \\
\text { valve stem leak } \\
\text { valve body crack }\end{array}$ & $\begin{array}{l}\text { Large gas release at } \\
\text { ground level } \\
\text { small gas release at } \\
\text { ground level } \\
\text { small gas release at } \\
\text { ground level }\end{array}$ & $\begin{array}{l}\text { Alarm on tank } \\
\text { level } \\
\text { sensors detect gas } \\
\text { release } \\
\text { sensors detect gas } \\
\text { release }\end{array}$ \\
\hline$V-24$ & $\begin{array}{l}\text { transport return } \\
\text { valve } \\
\mathrm{NC}\end{array}$ & $\begin{array}{l}\text { gaseous NG return } \\
\text { to tanker ullage } \\
\text { from pressure tank } \\
\text { ullage }\end{array}$ & $\begin{array}{l}\text { Fail to remain } \\
\text { closed } \\
\text { Internal leak } \\
\text { External leak }\end{array}$ & $\begin{array}{l}\text { mechanical fault } \\
\text { valve seat scored } \\
\text { valve stem leak } \\
\text { valve body crack }\end{array}$ & $\begin{array}{l}\text { Large gas release at } \\
\text { ground level } \\
\text { small gas release at } \\
\text { ground level } \\
\text { small gas release at } \\
\text { ground level }\end{array}$ & $\begin{array}{l}\text { Alarm on tank } \\
\text { level } \\
\text { sensors detect gas } \\
\text { release } \\
\text { sensors detect gas } \\
\text { release }\end{array}$ \\
\hline$V-25$ & $\begin{array}{l}\text { transport suction } \\
\text { valve } \\
\text { NC }\end{array}$ & $\begin{array}{l}\text { isolation valve for } \\
\text { tanker fill line }\end{array}$ & $\begin{array}{l}\text { Fails to remain } \\
\text { closed } \\
\text { Internal leak } \\
\text { External leak }\end{array}$ & $\begin{array}{l}\text { mechanical fault } \\
\text { valve seat scored } \\
\text { valve stem leak } \\
\text { valve body crack }\end{array}$ & $\begin{array}{l}\text { Large gas release at } \\
\text { ground level } \\
\text { small gas release at } \\
\text { ground level } \\
\text { small gas release at } \\
\text { ground level }\end{array}$ & $\begin{array}{l}\text { Alarm on tank } \\
\text { level } \\
\text { sensors detect gas } \\
\text { release } \\
\text { sensors detect gas } \\
\text { release }\end{array}$ \\
\hline $\mathrm{V}-26$ & $\begin{array}{l}\text { N2 purge valve } \\
\text { NC }\end{array}$ & $\begin{array}{l}\text { valve between N2 } \\
\text { gas bottles and } \\
\text { ullage of pressure } \\
\text { tank to purge the } \\
\text { tank of } \\
\text { consensibles and } \\
\text { other impurity } \\
\text { gases }\end{array}$ & $\begin{array}{l}\text { Fails to remain } \\
\text { closed } \\
\text { Internal leak } \\
\text { External leak }\end{array}$ & $\begin{array}{l}\text { mechanical fault } \\
\text { valve seat scored } \\
\text { valve stem leak } \\
\text { valve body crack }\end{array}$ & $\begin{array}{l}\text { Large gas release at } \\
\text { ground level } \\
\text { small gas release at } \\
\text { ground level } \\
\text { small gas release at } \\
\text { ground level }\end{array}$ & $\begin{array}{l}\text { Alarm on tank } \\
\text { level } \\
\text { sensors detect gas } \\
\text { release } \\
\text { sensors detect gas } \\
\text { release }\end{array}$ \\
\hline
\end{tabular}




\begin{tabular}{|c|c|c|c|c|c|c|}
\hline $\mathrm{V}-27$ & $\begin{array}{l}\text { sample isolation } \\
\text { valve } \\
\mathrm{NC}\end{array}$ & $\begin{array}{l}\text { shut off valve for } \\
\text { sample cylinder } \\
\text { connection C-1 }\end{array}$ & $\begin{array}{l}\begin{array}{l}\text { Fails to remain } \\
\text { closed }\end{array} \\
\text { Internal leak } \\
\text { External leak }\end{array}$ & $\begin{array}{l}\text { mechanical fault } \\
\text { valve seat scored } \\
\text { valve stem leak } \\
\text { valve body crack }\end{array}$ & $\begin{array}{l}\text { Large LNG release } \\
\text { at ground level } \\
\text { small LNG release } \\
\text { at ground level } \\
\text { small LNG release } \\
\text { at ground level }\end{array}$ & \begin{tabular}{|l|} 
Alarm on tank \\
level \\
sensors detect gas \\
release \\
sensors detect gas \\
release
\end{tabular} \\
\hline $\mathrm{V}-28$ & $\begin{array}{l}\text { sample vent valve } \\
\text { NC }\end{array}$ & $\begin{array}{l}\text { shut off valve for } \\
\text { sample cylinder } \\
\text { vent through } \\
\text { connection C-2 }\end{array}$ & 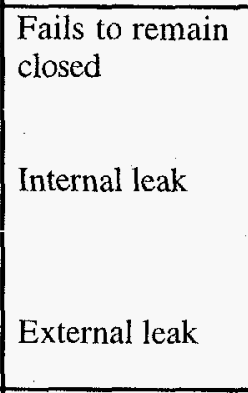 & $\begin{array}{l}\text { mechanical fault } \\
\text { valve seat scored } \\
\text { valve stem leak } \\
\text { valve body crack }\end{array}$ & $\begin{array}{l}\text { no effect until } \\
\text { taking a sample } \\
\text { no effect until } \\
\text { taking a sample } \\
\text { no effect until } \\
\text { taking a sample }\end{array}$ & \\
\hline$V-29$ & $\begin{array}{l}\text { sample purge valve } \\
\mathrm{NC}\end{array}$ & $\begin{array}{l}\text { shut off valve for } \\
\text { purging the sample } \\
\text { line, connects to C- } \\
3\end{array}$ & 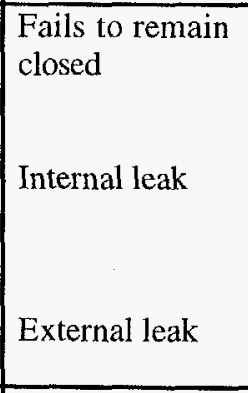 & $\begin{array}{l}\text { mechanical fault } \\
\text { valve seat scored } \\
\text { valve stem leak } \\
\text { valve body crack }\end{array}$ & $\begin{array}{l}\text { no effect until } \\
\text { taking a sample } \\
\text { no effect until } \\
\text { taking a sample } \\
\text { no effect until } \\
\text { taking a sample }\end{array}$ & \\
\hline $\mathrm{V}-30$ & $\begin{array}{l}\text { top fill isolation } \\
\text { valve } \\
\mathrm{NC}\end{array}$ & \begin{tabular}{|l|} 
second shut off \\
valve with $V-1$ \\
double block for \\
storage tank top fill \\
from tanker
\end{tabular} & $\begin{array}{l}\begin{array}{l}\text { Fails to remain } \\
\text { closed }\end{array} \\
\text { Internal leak } \\
\text { External leak }\end{array}$ & $\begin{array}{l}\text { mechanical fault } \\
\text { valve seat scored } \\
\text { valve stem leak } \\
\text { valve body crack } \\
\end{array}$ & $\begin{array}{l}\begin{array}{l}\text { Large gas release at } \\
\text { ground level }\end{array} \\
\text { small gas release at } \\
\text { ground level } \\
\text { small gas release at } \\
\text { ground level }\end{array}$ & \begin{tabular}{|l}
$\begin{array}{l}\text { Alarm on tank } \\
\text { level }\end{array}$ \\
sensors detect gas \\
release \\
sensors detect gas \\
release \\
\end{tabular} \\
\hline
\end{tabular}




\begin{tabular}{|c|c|c|c|c|c|c|}
\hline V-31 & $\begin{array}{l}\mathrm{F}-1 \text { isolation valve } \\
\mathrm{NC}\end{array}$ & $\begin{array}{l}\text { isolates the fill line } \\
\text { to end use vehicles }\end{array}$ & $\begin{array}{l}\text { Fails to remain } \\
\text { closed } \\
\text { Internal leak } \\
\text { External leak }\end{array}$ & $\begin{array}{l}\text { mechanical fault } \\
\text { valve seat scored } \\
\text { valve stem leak } \\
\text { valve body crack }\end{array}$ & $\begin{array}{l}\text { Large LNG release } \\
\text { through transfer } \\
\text { hose } \\
\text { small gas release } \\
\text { through transfer } \\
\text { hose } \\
\text { small gas release } \\
\text { through transfer } \\
\text { hose }\end{array}$ & $\begin{array}{l}\begin{array}{l}\text { Alarm on tank } \\
\text { level }\end{array} \\
\text { sensors detect gas } \\
\text { release } \\
\text { sensors detect gas } \\
\text { release }\end{array}$ \\
\hline $\mathrm{V}-32$ & $\begin{array}{l}\text { PSV } 101 \mathrm{~A} \text { test } \\
\text { valve } \\
\text { NC }\end{array}$ & $\begin{array}{l}\text { bypass valve to } \\
\text { stack for pressure } \\
\text { relief valve } 101 \mathrm{~A}\end{array}$ & $\begin{array}{l}\text { Fails to remain } \\
\text { closed } \\
\text { Internal leak } \\
\text { External leak }\end{array}$ & $\begin{array}{l}\text { mechanical fault } \\
\text { valve seat scored } \\
\text { valve stem leak } \\
\text { valve body crack }\end{array}$ & $\begin{array}{l}\text { Large gas release to } \\
\text { the stack } \\
\text { small gas release to } \\
\text { stack } \\
\text { small gas release to } \\
\text { ground level }\end{array}$ & $\begin{array}{l}\text { Alarm on storage } \\
\text { tank liquid level } \\
\text { tank pressure } \\
\text { decrease } \\
\text { sensors detect gas } \\
\text { release }\end{array}$ \\
\hline $\mathrm{V}-33$ & $\begin{array}{l}\text { PSV-101B test } \\
\text { valve } \\
\mathrm{NC}\end{array}$ & $\begin{array}{l}\text { bypass valve to } \\
\text { stack for pressure } \\
\text { relief valve } 101 \mathrm{~B}\end{array}$ & $\begin{array}{l}\text { Fails to remain } \\
\text { closed } \\
\text { Internal leak } \\
\text { External leak }\end{array}$ & $\begin{array}{l}\text { mechanical fault } \\
\text { valve seat scored } \\
\text { valve stem leak } \\
\text { valve body crack }\end{array}$ & $\begin{array}{l}\text { Large gas release to } \\
\text { the stack } \\
\text { small gas release to } \\
\text { stack } \\
\text { small gas release to } \\
\text { ground level }\end{array}$ & $\begin{array}{l}\text { Alarm on storage } \\
\text { tank liquid level } \\
\text { tank pressure } \\
\text { decrease } \\
\text { sensors detect gas } \\
\text { release }\end{array}$ \\
\hline $\mathrm{V}-34$ & $\begin{array}{l}\text { PSV-105B test } \\
\text { valve } \\
\mathrm{NC}\end{array}$ & $\begin{array}{l}\text { bypass valve to } \\
\text { stack for pressure } \\
\text { relief valve } 105 B\end{array}$ & $\begin{array}{l}\text { Fails to remain } \\
\text { closed } \\
\text { Internal leak } \\
\text { External leak }\end{array}$ & $\begin{array}{l}\text { mechanical fault } \\
\text { valve seat scored } \\
\text { valve stem leak } \\
\text { valve body crack }\end{array}$ & $\begin{array}{l}\text { Large LNG release } \\
\text { to the stack } \\
\text { small LNG release } \\
\text { to stack } \\
\text { small LNG release } \\
\text { to ground level }\end{array}$ & $\begin{array}{l}\text { Alarm on storage } \\
\text { tank liquid level } \\
\text { tank pressure } \\
\text { decrease } \\
\text { sensors detect gas } \\
\text { release }\end{array}$ \\
\hline
\end{tabular}




\begin{tabular}{|c|c|c|c|c|c|c|}
\hline$V-35$ & $\begin{array}{l}\text { PSV-105A test } \\
\text { valve } \\
\text { NC }\end{array}$ & $\begin{array}{l}\text { bypass valve to } \\
\text { stack for pressure } \\
\text { relief valve } 105 \mathrm{~A}\end{array}$ & $\begin{array}{l}\text { Fails to remain } \\
\text { closed } \\
\text { Internal leak } \\
\text { External leak }\end{array}$ & $\begin{array}{l}\text { mechanical fault } \\
\text { valve seat scored } \\
\text { valve stem leak } \\
\text { valve body crack }\end{array}$ & $\begin{array}{l}\text { Large gas release to } \\
\text { the stack } \\
\text { small gas release to } \\
\text { stack } \\
\text { small gas release to } \\
\text { ground level }\end{array}$ & $\begin{array}{l}\text { Alarm on storage } \\
\text { tank liquid level } \\
\text { tank pressure } \\
\text { decrease } \\
\text { sensors detect gas } \\
\text { release }\end{array}$ \\
\hline$V-36$ & $\begin{array}{l}\text { PSV-104C test } \\
\text { valve } \\
\mathrm{NC}\end{array}$ & $\begin{array}{l}\text { bypass valve to } \\
\text { stack for pressure } \\
\text { relief valve } 104 \mathrm{C}\end{array}$ & $\begin{array}{l}\text { Fails to remain } \\
\text { closed } \\
\text { Internal leak } \\
\text { External leak }\end{array}$ & $\begin{array}{l}\text { mechanical fault } \\
\text { valve seat scored } \\
\text { valve stem leak } \\
\text { valve body crack }\end{array}$ & $\begin{array}{l}\text { Large gas release to } \\
\text { the stack } \\
\text { small gas release to } \\
\text { stack } \\
\text { sniall gas release to } \\
\text { ground level }\end{array}$ & $\begin{array}{l}\text { Alarm on storage } \\
\text { tank liquid level } \\
\text { tank pressure } \\
\text { decrease } \\
\text { sensors detect gas } \\
\text { release }\end{array}$ \\
\hline$V-37$ & $\begin{array}{l}\text { PSV-104B test } \\
\text { valve } \\
\text { NC }\end{array}$ & $\begin{array}{l}\text { bypass valve to } \\
\text { stack for pressure } \\
\text { relief valve } 104 \mathrm{~B}\end{array}$ & $\begin{array}{l}\text { Fails to remain } \\
\text { closed } \\
\text { Internal leak } \\
\text { External leak }\end{array}$ & $\begin{array}{l}\text { mechanical fault } \\
\text { valve seat scored } \\
\text { valve stem leak } \\
\text { valve body crack }\end{array}$ & $\begin{array}{l}\text { small gas release to } \\
\text { the stack } \\
\text { small gas release to } \\
\text { stack } \\
\text { small gas release to } \\
\text { ground level }\end{array}$ & $\begin{array}{l}\text { fill line not alarmed } \\
\text { fill line has no } \\
\text { effect on system } \\
\text { fill line has no } \\
\text { effect on system }\end{array}$ \\
\hline$\overline{C V}-1$ & $\begin{array}{l}\text { fill check valve } \\
\text { NC }\end{array}$ & $\begin{array}{l}\text { prevent reverse flow } \\
\text { into tanker when } \\
\text { top filling storage } \\
\text { tank }\end{array}$ & $\begin{array}{l}\text { Fails to remain } \\
\text { closed } \\
\text { External leak }\end{array}$ & $\begin{array}{l}\text { mechanical fault } \\
\text { valve body crack }\end{array}$ & $\begin{array}{l}\text { small gas release to } \\
\text { the stack } \\
\text { small gas release to } \\
\text { ground level }\end{array}$ & $\begin{array}{l}\text { fill line not alarmed } \\
\text { fill line has no } \\
\text { effect on system }\end{array}$ \\
\hline CV-2 & $\begin{array}{l}\text { saturation return } \\
\text { check valve } \\
\text { NO }\end{array}$ & $\begin{array}{l}\text { prevent reverse } \\
\text { liquid flow from } \\
\text { storage tank into } \\
\text { gas return line }\end{array}$ & $\begin{array}{l}\text { Fails to remain } \\
\text { open/plugging } \\
\text { External leak }\end{array}$ & $\begin{array}{l}\text { mechanical fault } \\
\text { pressure imbalance } \\
\text { valve body crack }\end{array}$ & $\begin{array}{l}\text { cannot return gas to } \\
\text { storage tank, as } \\
\text { liquid level drops } \\
\text { then ST pressure } \\
\text { also drops } \\
\text { small gas/LNG } \\
\text { leak at ground level }\end{array}$ & $\begin{array}{l}\text { storage tank } \\
\text { pressure is } \\
\text { monitored } \\
\text { sensors detect leak }\end{array}$ \\
\hline
\end{tabular}




\begin{tabular}{|c|c|c|c|c|c|c|}
\hline$\overline{C V}-3$ & $\begin{array}{l}\text { spring check valve } \\
\text { on discharge line } \\
\mathrm{NC}\end{array}$ & $\begin{array}{l}\text { prevent reverse flow } \\
\text { from end use } \\
\text { vehicle fuel tank } \\
\text { into pressure tank; } \\
\text { FCV-107 must also } \\
\text { close, or V-31 must } \\
\text { close }\end{array}$ & $\begin{array}{l}\begin{array}{l}\text { Fails to remain } \\
\text { closed }\end{array} \\
\text { External leak } \\
\text { Internal leak }\end{array}$ & $\begin{array}{l}\text { valve body crack } \\
\text { foreign material } \\
\text { valve seat scored }\end{array}$ & $\begin{array}{l}\text { large LNG leak } \\
\text { from transfer hose } \\
\text { small LNG leak } \\
\text { from valve body } \\
\text { small LNG leak } \\
\text { through valve, out } \\
\text { TH-1 }\end{array}$ & $\begin{array}{l}\text { level sensors will } \\
\text { detect tank level } \\
\text { decrease } \\
\text { gas sensors to } \\
\text { detect this leak } \\
\text { gas sensors may } \\
\text { not detect this leak, } \\
\text { end of hose TH-1 is } \\
\text { far from sensors } \\
\end{array}$ \\
\hline PSV-101A & $\begin{array}{l}\text { inner vessel safety } \\
\text { valve } \\
\text { NC }\end{array}$ & $\begin{array}{l}\text { first in line } \\
\text { overpressure relief } \\
\text { for storage tank } \\
\text { ullage, vents to } \\
\text { stack }\end{array}$ & $\begin{array}{l}\begin{array}{l}\text { Fails to remain } \\
\text { closed }\end{array} \\
\text { Fail to open on } \\
\text { demand } \\
\text { Simmer } \\
\end{array}$ & $\begin{array}{l}\text { spring failure } \\
\text { freeze up, } \\
\text { mechanical fault } \\
\text { spring relaxation } \\
\end{array}$ & $\begin{array}{l}\text { Large gas release to } \\
\text { stack } \\
\text { rupture disks or } \\
\text { alternate PSV lifts } \\
\text { small releases of } \\
\text { gas up stack }\end{array}$ & $\begin{array}{l}\text { level sensors will } \\
\text { detect tank level } \\
\text { decrease } \\
\text { level sensors will } \\
\text { detect tank level } \\
\text { decrease } \\
\text { may not be detected } \\
\end{array}$ \\
\hline PSV-101B & $\begin{array}{l}\text { inner vessel safety } \\
\text { valve } \\
\mathrm{NC}\end{array}$ & $\begin{array}{l}\text { second in line } \\
\text { overpressure relief } \\
\text { for storage tank } \\
\text { ullage, vents to } \\
\text { stack }\end{array}$ & $\begin{array}{l}\text { Fails to remain } \\
\text { closed } \\
\text { Fail to open on } \\
\text { demand }\end{array}$ & $\begin{array}{l}\text { spring failure } \\
\text { freeze up, } \\
\text { mechanical fault }\end{array}$ & $\begin{array}{l}\text { no release unless } \\
\text { V-20 also leaks } \\
\text { rupture disks still } \\
\text { available }\end{array}$ & $\begin{array}{l}\text { no release } \\
\text { level sensors will } \\
\text { detect tank level } \\
\text { decrease }\end{array}$ \\
\hline PSV-101C & $\begin{array}{l}\text { saturation pressure } \\
\text { safety valve } \\
\mathrm{NC}\end{array}$ & $\begin{array}{l}\text { overpressure relief } \\
\text { for storage tank } \\
\text { liquid space, vents } \\
\text { to stack }\end{array}$ & $\begin{array}{l}\begin{array}{l}\text { Fails to remain } \\
\text { closed }\end{array} \\
\begin{array}{l}\text { Fail to open on } \\
\text { demand }\end{array} \\
\text { Simmer }\end{array}$ & $\begin{array}{l}\text { spring failure } \\
\text { freeze up, } \\
\text { mechanical fault } \\
\text { spring relaxation }\end{array}$ & $\begin{array}{l}\text { Large LNG release } \\
\text { to stack } \\
\text { rupture disks or } \\
\text { alternate gas PSVs } \\
\text { lift } \\
\text { small releases of } \\
\text { LNG up stack }\end{array}$ & \begin{tabular}{|l|} 
level sensors will \\
detect tank level \\
decrease \\
level sensors will \\
detect tank level \\
decrease \\
may not be detected
\end{tabular} \\
\hline
\end{tabular}




\begin{tabular}{|c|c|c|c|c|c|c|}
\hline$\overline{P S V}-102 \mathrm{~A}$ & $\begin{array}{l}\text { pump sump safety } \\
\text { valve } \\
\text { NC }\end{array}$ & $\begin{array}{l}\text { overpressure relief } \\
\text { for pressure tank } \\
\text { gas ullage space }\end{array}$ & 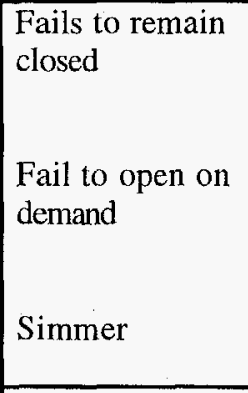 & $\begin{array}{l}\text { spring failure } \\
\text { freeze up, } \\
\text { mechanical fault } \\
\text { spring relaxation }\end{array}$ & $\begin{array}{l}\text { Large gas release to } \\
\text { stack } \\
\text { rupture disks or } \\
\text { alternate PSV lifts } \\
\text { on ST } \\
\text { small releases of } \\
\text { gas up stack }\end{array}$ & $\begin{array}{l}\text { level sensors will } \\
\text { detect tank level } \\
\text { decrease } \\
\text { level sensors will } \\
\text { detect tank level } \\
\text { decrease } \\
\text { may not be detected }\end{array}$ \\
\hline PSV-102B & $\begin{array}{l}\text { dispensing line } \\
\text { safety valve } \\
\text { NC }\end{array}$ & $\begin{array}{l}\text { overpressure relief } \\
\text { valve for dispensing } \\
\text { line }\end{array}$ & $\begin{array}{l}\begin{array}{l}\text { Fails to remain } \\
\text { closed }\end{array} \\
\text { Fail to open on } \\
\text { demand } \\
\text { Simmer }\end{array}$ & $\begin{array}{l}\text { spring failure } \\
\text { freeze up, } \\
\text { mechanical fault } \\
\text { spring relaxation }\end{array}$ & $\begin{array}{l}\text { Large LNG release } \\
\text { to stack } \\
\text { rupture disks or } \\
\text { alternate gás PSV's } \\
\text { lift } \\
\text { small releases of } \\
\text { LNG up stack } \\
\end{array}$ & $\begin{array}{l}\text { level sensors will } \\
\text { detect tank level } \\
\text { decrease } \\
\text { level sensors will } \\
\text { detecti tank leveì } \\
\text { decrease } \\
\text { may not be detected }\end{array}$ \\
\hline PSV-103 & $\begin{array}{l}\text { transport suction } \\
\text { line safety valve } \\
\text { NC }\end{array}$ & $\begin{array}{l}\text { overpressure relief } \\
\text { valve for tanker fill } \\
\text { line } \\
\text { Valved out during } \\
\text { normal operation } \\
\end{array}$ & & & & \\
\hline PSV-104A & $\begin{array}{l}\text { top fill line safety } \\
\text { valve } \\
\text { NC }\end{array}$ & $\begin{array}{l}\text { overpressure relief } \\
\text { valve for top fill } \\
\text { line } \\
\text { Valved out during } \\
\text { normal operation } \\
\end{array}$ & & & & \\
\hline PSV-104B & $\begin{array}{l}\text { top fill line safety } \\
\text { valve } \\
\text { NC }\end{array}$ & \begin{tabular}{|l|} 
overpressure relief \\
valve for V-1, V-30 \\
double block on top \\
fill line \\
Valved out during \\
normal operation \\
\end{tabular} & & & & \\
\hline
\end{tabular}




\begin{tabular}{|c|c|c|c|c|c|c|}
\hline PSV-104C & $\begin{array}{l}\text { saturation return } \\
\text { line safety valve } \\
\text { NC }\end{array}$ & $\begin{array}{l}\text { overpressure relief } \\
\text { valve for saturation } \\
\text { gas line to storage } \\
\text { tank between V-15 } \\
\text { and V-23 }\end{array}$ & $\begin{array}{l}\text { Fails to remain } \\
\text { closed } \\
\text { Fail to open on } \\
\text { demand } \\
\text { Simmer }\end{array}$ & $\begin{array}{l}\text { spring failure } \\
\text { freeze up, } \\
\text { mechanical fault } \\
\text { spring relaxation }\end{array}$ & $\begin{array}{l}\text { Large gas release to } \\
\text { stack } \\
\text { alternate gas PSV } \\
\text { lifts } \\
\text { small releases of } \\
\text { gas up stack }\end{array}$ & $\begin{array}{l}\text { level sensors will } \\
\text { detect tank level } \\
\text { decrease } \\
\text { level sensors will } \\
\text { detect tank level } \\
\text { decrease } \\
\text { may not be detected }\end{array}$ \\
\hline PSV-104D & $\begin{array}{l}\text { saturation return } \\
\text { line safety valve } \\
\text { NC }\end{array}$ & $\begin{array}{l}\text { overpressure relief } \\
\text { valve for saturation } \\
\text { gas return line } \\
\text { between } V-15 \text { and } \\
V-23\end{array}$ & $\begin{array}{l}\text { Fails to remain } \\
\text { closed } \\
\text { Fail to open on } \\
\text { demand } \\
\text { Simmer }\end{array}$ & $\begin{array}{l}\text { spring failure } \\
\text { freeze up, } \\
\text { mechanical fault } \\
\text { spring relaxation }\end{array}$ & $\begin{array}{l}\text { Large gas release to } \\
\text { stack } \\
\text { alternate gas PSV } \\
\text { lifts } \\
\text { small releases of } \\
\text { gas up stack }\end{array}$ & $\begin{array}{l}\text { level sensors will } \\
\text { detect tank level } \\
\text { decrease } \\
\text { level sensors will } \\
\text { detect tank level } \\
\text { decrease } \\
\text { may not be detected }\end{array}$ \\
\hline PSV-105A & $\begin{array}{l}\text { pump vent line } \\
\text { safety valve } \\
\text { NC }\end{array}$ & $\begin{array}{l}\text { overpressure relief } \\
\text { valve for pressure } \\
\text { tank ullage space }\end{array}$ & $\begin{array}{l}\text { Fails to remain } \\
\text { closed } \\
\text { Fail to open on } \\
\text { demand } \\
\text { Simmer }\end{array}$ & $\begin{array}{l}\text { spring failure } \\
\text { freeze up, } \\
\text { mechanical fault } \\
\text { spring relaxation }\end{array}$ & $\begin{array}{l}\text { Large gas/LNG } \\
\text { release to stack } \\
\text { rupture disks or } \\
\text { alternate gas PSVs } \\
\text { lift } \\
\text { small releases of } \\
\text { gas/LNG up stack }\end{array}$ & $\begin{array}{l}\text { level sensors will } \\
\text { detect tank level } \\
\text { decrease } \\
\text { level sensors will } \\
\text { detect tank level } \\
\text { decrease } \\
\text { may not be detected }\end{array}$ \\
\hline PSV-105B & $\begin{array}{l}\text { pump feed line } \\
\text { safety valve } \\
\mathrm{NC}\end{array}$ & $\begin{array}{l}\text { overpressure relief } \\
\text { valve for pump feed } \\
\text { line }\end{array}$ & $\begin{array}{l}\text { Fails to remain } \\
\text { closed } \\
\text { Fail to open on } \\
\text { demand }\end{array}$ & $\begin{array}{l}\text { spring failure } \\
\text { freeze up, } \\
\text { mechanical fault } \\
\text { spring relaxation }\end{array}$ & $\begin{array}{l}\text { Large LNG release } \\
\text { to stack } \\
\text { rupture disks or } \\
\text { alternate gas PSVs } \\
\text { lift } \\
\text { small releases of } \\
\text { LNG up stack } \\
\end{array}$ & $\begin{array}{l}\text { level sensors will } \\
\text { detect tank level } \\
\text { decrease } \\
\text { level sensors will } \\
\text { detect tank level } \\
\text { decrease } \\
\text { may not be detected }\end{array}$ \\
\hline
\end{tabular}




\begin{tabular}{|c|c|c|c|c|c|c|}
\hline PSE-101A & $\begin{array}{l}\text { rupture disk, inner } \\
\text { vessel } \\
\mathrm{NC}\end{array}$ & $\begin{array}{l}\text { preferred path of } \\
\text { overpressure gas } \\
\text { from V-20, opens } \\
\text { to stack }\end{array}$ & $\begin{array}{l}\text { Internal leak } \\
\text { Spuriously open } \\
\text { Fail to open on } \\
\text { demand }\end{array}$ & $\begin{array}{l}\text { flaws in metal } \\
\text { metal fatigue } \\
\text { ice buildup or } \\
\text { blockage }\end{array}$ & $\begin{array}{l}\text { small release of gas } \\
\text { up the stack } \\
\text { large release of gas } \\
\text { up the stack } \\
\text { alternative pressure } \\
\text { relief devices are } \\
\text { challenged }\end{array}$ & $\begin{array}{l}\text { may not be detected } \\
\text { level sensors will } \\
\text { detect tank level } \\
\text { decrease } \\
\text { level sensors will } \\
\text { detect tank level } \\
\text { decrease }\end{array}$ \\
\hline PSE-101B & $\begin{array}{l}\text { rupture disk, inner } \\
\text { vessel } \\
\mathrm{NC} \\
\end{array}$ & $\begin{array}{l}\text { secondary path of } \\
\text { overpressure gas } \\
\text { from V-20, opens } \\
\text { to stack } \\
\end{array}$ & $\begin{array}{l}\text { Fail to open on } \\
\text { demand }\end{array}$ & $\begin{array}{l}\text { ice buildup or } \\
\text { blockage }\end{array}$ & $\begin{array}{l}\text { alternative pressure } \\
\text { relief devices are } \\
\text { challenged }\end{array}$ & $\begin{array}{l}\text { level sensors will } \\
\text { detect tank level } \\
\text { decrease }\end{array}$ \\
\hline PSE-101C & $\begin{array}{l}\text { rupture disk, outer } \\
\text { vessel } \\
\mathrm{NC}\end{array}$ & \begin{tabular}{|l|} 
pressure relief for \\
the vacuum annulus \\
in case of cryogen \\
admission to \\
vacuum space
\end{tabular} & $\begin{array}{l}\text { Internal leak } \\
\text { Spuriously open } \\
\text { Fail to open on } \\
\text { demand }\end{array}$ & $\begin{array}{l}\text { flaws in metal } \\
\text { metal fatigue } \\
\begin{array}{l}\text { ice buildup or } \\
\text { blockage }\end{array}\end{array}$ & $\begin{array}{l}\text { Vacuum degraded, } \\
\text { boiloff increases in } \\
\text { storage tank } \\
\text { Vacuum lost, tank } \\
\text { contents boil } \\
\text { vigorously } \\
\text { If rupture disk does } \\
\text { not open, pressure } \\
\text { will split carbon } \\
\text { steel outer shell }\end{array}$ & $\begin{array}{l}\text { Slow increase in } \\
\text { bôiloff may not be } \\
\text { noticed } \\
\text { Pressure relief } \\
\text { vents tank } \\
\\
\text { Catastrophic event, } \\
\text { bund wall confines } \\
\text { spill }\end{array}$ \\
\hline PSE-102 & $\begin{array}{l}\text { rupture disk, pump } \\
\text { sump } \\
\text { NC }\end{array}$ & $\begin{array}{l}\text { pressure relief for } \\
\text { pressure tank }\end{array}$ & $\begin{array}{l}\text { Internal leak } \\
\text { Spuriously open } \\
\text { Fail to open on } \\
\text { demand }\end{array}$ & $\begin{array}{l}\text { flaws in metal } \\
\text { metal fatigue } \\
\text { ice buildup or } \\
\text { blockage }\end{array}$ & $\begin{array}{l}\text { small release of gas } \\
\text { up the stack } \\
\text { large release of gas } \\
\text { up the stack } \\
\text { alternative pressure } \\
\text { relief devices are } \\
\text { challenged }\end{array}$ & $\begin{array}{l}\text { may not be detected } \\
\text { level sensors will } \\
\text { detect tank level } \\
\text { decrease } \\
\text { level sensors will } \\
\text { detect tank level } \\
\text { decrease }\end{array}$ \\
\hline
\end{tabular}




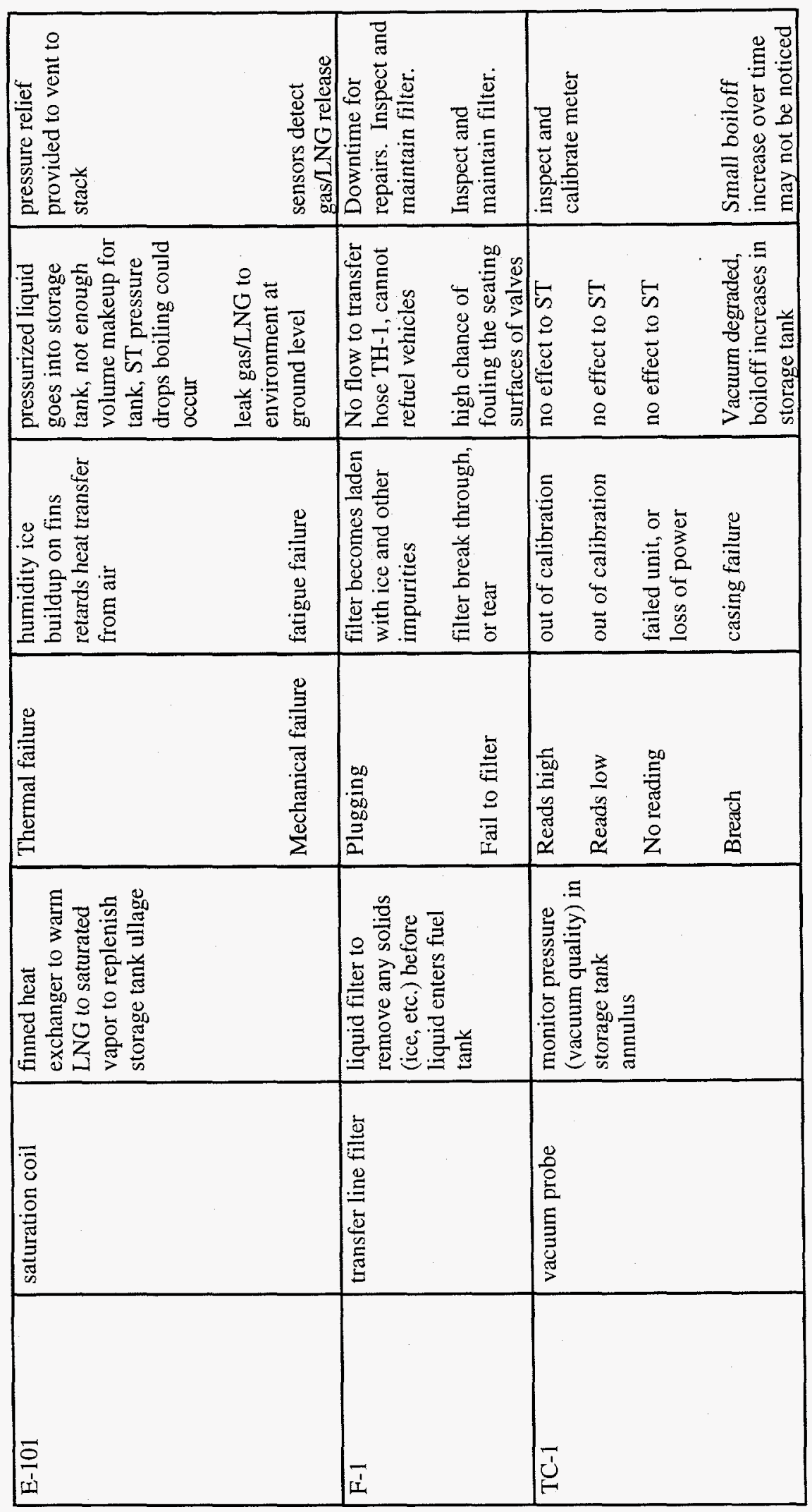




\begin{tabular}{|c|c|c|c|c|c|c|}
\hline PDI-101 & $\begin{array}{l}\text { liquid level } \\
\text { indicator }\end{array}$ & $\begin{array}{l}\text { differential pressure } \\
\text { sensor for liquid } \\
\text { level indication }\end{array}$ & $\begin{array}{l}\text { Reads high } \\
\text { Reads low } \\
\text { No reading } \\
\text { Breach }\end{array}$ & $\begin{array}{l}\text { out of calibration } \\
\text { out of calibration } \\
\text { failed unit, or } \\
\text { loss of power } \\
\text { casing failure }\end{array}$ & \begin{tabular}{|l|}
$\begin{array}{l}\text { False idea of liquid } \\
\text { inventory, could } \\
\text { result in using up } \\
\text { heel and require } \\
\text { cooling hot tank } \\
\text { False idea of liquid } \\
\text { inventory } \\
\text { May interfere with } \\
\text { operations } \\
\text { small release of } \\
\text { gas/LNG at ground } \\
\text { level }\end{array}$ \\
\end{tabular} & $\begin{array}{l}\text { Operator must } \\
\text { understand trends of } \\
\text { operation and must } \\
\text { calibrate } \\
\text { instruments } \\
\text { No harm unless } \\
\text { tank is overfilled } \\
\text { Zero reading should } \\
\text { be obvious to fix } \\
\text { sensors detect gas } \\
\text { release }\end{array}$ \\
\hline PDT-101 & $\begin{array}{l}\text { liquid level } \\
\text { transmitter }\end{array}$ & $\begin{array}{l}\text { differential pressure } \\
\text { transmitter for local } \\
\text { indication }\end{array}$ & $\begin{array}{l}\text { High signal } \\
\text { Low signal } \\
\text { No signal }\end{array}$ & $\begin{array}{l}\text { out of calibration } \\
\text { out of calibration } \\
\text { failed unit, or loss } \\
\text { of power }\end{array}$ & \begin{tabular}{|l|} 
False idea of liquid \\
inventory, could \\
result in using up \\
heel and require \\
cooling hot tank \\
False idea of liquid \\
inventory \\
May interfere with \\
operations
\end{tabular} & $\begin{array}{l}\text { Operator must } \\
\text { understand trends of } \\
\text { operation and must } \\
\text { calibrate } \\
\text { instruments } \\
\text { No harm unless } \\
\text { tank is overfilled } \\
\text { Zero reading should } \\
\text { be obvious to fix }\end{array}$ \\
\hline$\overline{M-1}$ & meter & $\begin{array}{l}\text { instrument to } \\
\text { measure the } \\
\text { quantity of fluid } \\
\text { dispensed }\end{array}$ & $\begin{array}{l}\text { Plugging } \\
\text { External leak } \\
\\
\text { Incorrect } \\
\text { measurement }\end{array}$ & $\begin{array}{l}\text { ice buildup } \\
\text { casing failure } \\
\text { out of calibration }\end{array}$ & \begin{tabular}{|l|}
$\begin{array}{l}\text { No flow to end use } \\
\text { vehicle tank }\end{array}$ \\
Reduced flow to \\
end use vehicle \\
tank, recirc in PT \\
False idea of liquid \\
inventory \\
dispensed. Will \\
not agree with level \\
indication.
\end{tabular} & $\begin{array}{l}\text { Routine inspection } \\
\text { and maintenance } \\
\text { choice of meter } \\
\text { influences failure } \\
\text { frequency } \\
\text { Operators must } \\
\text { watch for these } \\
\text { deviations }\end{array}$ \\
\hline
\end{tabular}




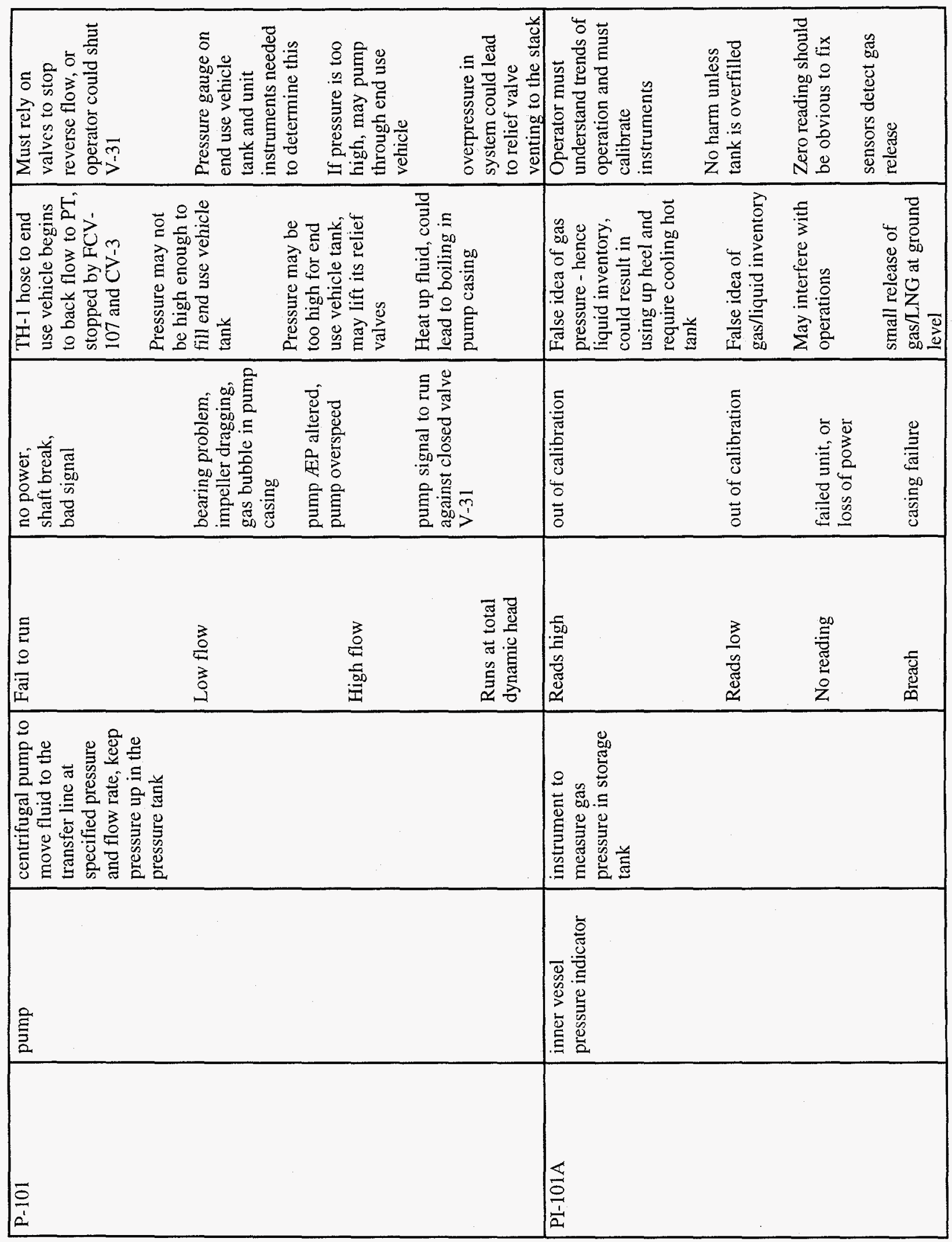




\begin{tabular}{|c|c|c|c|c|c|c|}
\hline PI-101B & $\begin{array}{l}\text { inner vessel } \\
\text { pressure indicator }\end{array}$ & $\begin{array}{l}\text { instrument to } \\
\text { measure liquid } \\
\text { pressure in storage } \\
\text { tank }\end{array}$ & $\begin{array}{l}\text { Reads high } \\
\text { Reads low } \\
\text { No reading } \\
\text { Breach }\end{array}$ & $\begin{array}{l}\text { out of calibration } \\
\text { out of calibration } \\
\text { failed unit, or } \\
\text { loss of power } \\
\text { casing failure }\end{array}$ & $\begin{array}{l}\text { False idea of liquid } \\
\text { inventory, could } \\
\text { result in using up } \\
\text { heel and require } \\
\text { cooling hot tank } \\
\text { False idea of liquid } \\
\text { inventory } \\
\text { May interfere with } \\
\text { operations } \\
\text { small release of } \\
\text { LNG at ground } \\
\text { leve! }\end{array}$ & $\begin{array}{l}\text { Operator must } \\
\text { understand trends of } \\
\text { operation and must } \\
\text { calibrate } \\
\text { instruments } \\
\text { No harm unless } \\
\text { tank is overfilled } \\
\text { Zero reading should } \\
\text { be obvious to fix } \\
\text { sensors detect gas } \\
\text { release }\end{array}$ \\
\hline
\end{tabular}




\begin{tabular}{|c|c|c|c|c|c|c|}
\hline PI-102A & $\begin{array}{l}\text { pump sump } \\
\text { pressure indicator }\end{array}$ & $\begin{array}{l}\text { instrument to } \\
\text { measure gas } \\
\text { pressure in the } \\
\text { pressure tank }\end{array}$ & $\begin{array}{l}\text { Reads high } \\
\text { Reads low } \\
\text { No reading } \\
\text { Breach }\end{array}$ & $\begin{array}{l}\text { out of calibration } \\
\text { out of calibration } \\
\text { failed unit, or } \\
\text { loss of power } \\
\text { casing failure }\end{array}$ & $\begin{array}{l}\text { System response to } \\
\text { high pressure is to } \\
\text { throttle down FCV- } \\
106 \text { to make less } \\
\text { saturated vapor, ST } \\
\text { pressure drops } \\
\text { System response to } \\
\text { low pressure is to } \\
\text { open up FCV-106 } \\
\text { to make more } \\
\text { saturated vapor, ST } \\
\text { pressure rises } \\
\text { ****System } \\
\text { response is } \\
\text { unknown for loss } \\
\text { of signal } \\
\text { small gas release at } \\
\text { ground level }\end{array}$ & $\begin{array}{l}\text { Pressure readings } \\
\text { will not agree, } \\
\text { operator must } \\
\text { determine which is } \\
\text { in error } \\
\text { Pressure readings } \\
\text { will not agree, } \\
\text { operator must } \\
\text { determine which is } \\
\text { in error } \\
\text { unknown } \\
\text { sensors detect gas } \\
\text { release }\end{array}$ \\
\hline
\end{tabular}




\begin{tabular}{|c|c|c|c|c|c|c|}
\hline PI-102B & $\begin{array}{l}\text { dispensing line } \\
\text { pressure indicator }\end{array}$ & $\begin{array}{l}\text { instrument to } \\
\text { measure liquid } \\
\text { pressure in transfer } \\
\text { line }\end{array}$ & $\begin{array}{l}\text { Reads high } \\
\text { Reads low } \\
\text { No reading } \\
\text { Breach }\end{array}$ & $\begin{array}{l}\text { out of calibration } \\
\text { out of calibration } \\
\text { failed unit, or } \\
\text { loss of power } \\
\text { casing failure }\end{array}$ & $\begin{array}{l}\text { May lead FCV-107 } \\
\text { to open while still } \\
\text { below end use } \\
\text { vehicle tank } \\
\text { pressure. Back } \\
\text { flow into pressure } \\
\text { tank } \\
\text { May lead FCV-107 } \\
\text { to open when } \\
\text { greatly above end } \\
\text { use vehicle tank } \\
\text { pressure. Could } \\
\text { cause overfill of } \\
\text { end use vehicle } \\
\text { tank. } \\
\text { FCV-107 will not } \\
\text { open, no flow to } \\
\text { EUV } \\
\text { small release of } \\
\text { LNG at ground } \\
\text { level }\end{array}$ & $\begin{array}{l}\text { Operator must } \\
\text { understand trends of } \\
\text { operation and must } \\
\text { calibrate } \\
\text { instruments } \\
\text { No harm unless end } \\
\text { use vehicle tank is } \\
\text { overfilled } \\
\text { Zero reading should } \\
\text { be obvious to fix } \\
\text { sensors detect gas } \\
\text { release }\end{array}$ \\
\hline PT-101A & $\begin{array}{l}\text { inner vessel } \\
\text { pressure transmitter }\end{array}$ & $\begin{array}{l}\text { pressure transmitter } \\
\text { for gas pressure } \\
\text { from storage tank }\end{array}$ & $\begin{array}{l}\text { High signal } \\
\text { Low signal } \\
\text { No signal }\end{array}$ & $\begin{array}{l}\text { out of calibration } \\
\text { out of calibration } \\
\text { failed unit, or loss } \\
\text { of power }\end{array}$ & $\begin{array}{l}\text { False idea of liquid } \\
\text { inventory, could } \\
\text { result in using up } \\
\text { heel and require } \\
\text { cooling hot tank } \\
\text { False idea of liquid } \\
\text { inventory } \\
\begin{array}{l}\text { May interfere with } \\
\text { operations }\end{array}\end{array}$ & $\begin{array}{l}\text { Operator must } \\
\text { understand trends of } \\
\text { operation and must } \\
\text { calibrate } \\
\text { instruments } \\
\text { No harm unless } \\
\text { tank is overfilled } \\
\text { Zero reading should } \\
\text { be obvious to fix }\end{array}$ \\
\hline
\end{tabular}




\begin{tabular}{|c|c|c|c|c|c|c|}
\hline PT-101B & $\begin{array}{l}\text { inner vessel } \\
\text { pressure transmitter }\end{array}$ & $\begin{array}{l}\text { pressure transmitter } \\
\text { for liquid pressure } \\
\text { from the storage } \\
\text { tank }\end{array}$ & $\begin{array}{l}\text { High signal } \\
\text { Low signal } \\
\text { No signal }\end{array}$ & $\begin{array}{l}\text { out of calibration } \\
\text { out of calibration } \\
\text { failed unit, or loss } \\
\text { of power }\end{array}$ & $\begin{array}{l}\text { False idea of liquid } \\
\text { inventory, could } \\
\text { result in using up } \\
\text { heel and require } \\
\text { cooling hot tank } \\
\text { False idea of liquid } \\
\text { inventory } \\
\text { May interfere with } \\
\text { operations }\end{array}$ & $\begin{array}{l}\text { Operator must } \\
\text { understand trends of } \\
\text { operation and must } \\
\text { calibrate } \\
\text { instruments } \\
\text { No harm unless } \\
\text { tank is overfilled } \\
\text { Zero reading should } \\
\text { be obvious to fix }\end{array}$ \\
\hline $\mathrm{TT}-102$ & temperature sensor & $\begin{array}{l}\text { temperature sensor } \\
\text { for gas ullage in the } \\
\text { pressure tank, with } \\
T \text { and P known, } \\
\text { operators can define } \\
\text { the thermodynamic } \\
\text { state of LNG }\end{array}$ & $\begin{array}{l}\text { High signal } \\
\text { Low signal } \\
\text { No signal }\end{array}$ & $\begin{array}{l}\text { out of calibration } \\
\text { out of calibration } \\
\text { failed unit, or loss } \\
\text { of power }\end{array}$ & $\begin{array}{l}\text { False idea of state } \\
\text { of LNG } \\
\text { False idea of state } \\
\text { of LNG } \\
\text { May interfere with } \\
\text { operations }\end{array}$ & $\begin{array}{l}\text { LNG could be okay } \\
\text { or subcooling } \\
\text { LNG could be okay } \\
\text { or warming } \\
\text { Zero reading should } \\
\text { be obvious to fix }\end{array}$ \\
\hline TH-1 & $\begin{array}{l}\text { metal braided } \\
\text { transfer hose }\end{array}$ & $\begin{array}{l}\text { flexible hose to } \\
\text { connect to end use } \\
\text { vehicle for refueling }\end{array}$ & $\begin{array}{l}\text { Plugging } \\
\text { External leak } \\
\text { Incomplete seal }\end{array}$ & $\begin{array}{l}\text { ice or hydrates built } \\
\text { up } \\
\text { wear, abrasion } \\
\text { foreign material } \\
\text { intrusion, operator } \\
\text { error }\end{array}$ & $\begin{array}{l}\text { No flow to end use } \\
\text { vehicle } \\
\text { small LNG release } \\
\text { at ground level } \\
\text { small or large LNG } \\
\text { release at ground } \\
\text { level }\end{array}$ & $\begin{array}{l}\text { Operator should } \\
\text { notice degraded } \\
\text { flow } \\
\text { Inspect and } \\
\text { maintain equipment } \\
\text { Inspect and } \\
\text { maintain equipment }\end{array}$ \\
\hline FC-1 & $\begin{array}{l}\text { top fill connection } \\
\mathrm{NC}\end{array}$ & $\begin{array}{l}\text { connector for tank } \\
\text { truck to fill storage } \\
\text { tank } \\
\text { Not used in this } \\
\text { mode of operation }\end{array}$ & & & & \\
\hline
\end{tabular}




\begin{tabular}{|c|c|c|c|c|c|c|}
\hline$\overline{\mathrm{FC}-2}$ & $\begin{array}{l}\text { vehicle fill } \\
\text { connection } \\
\text { NC }\end{array}$ & $\begin{array}{l}\text { connector at end of } \\
\text { TH- } 1 \text { to connect to } \\
\text { end use vehicle }\end{array}$ & $\begin{array}{l}\text { Incomplete seal } \\
\text { Fail to seal } \\
\text { Fail to detach }\end{array}$ & $\begin{array}{l}\text { ice or hydrates built } \\
\text { up, foreign material } \\
\text { intrusion, operator } \\
\text { error } \\
\text { mechanical failure } \\
\text { mechanical failure, } \\
\text { jammed }\end{array}$ & $\begin{array}{l}\begin{array}{l}\text { small or large LNG } \\
\text { release at ground } \\
\text { level }\end{array} \\
\begin{array}{l}\text { Cannot fill end use } \\
\text { vehicle tank }\end{array} \\
\begin{array}{l}\text { Stops operation, } \\
\text { cannot fuel other } \\
\text { vehicles }\end{array} \\
\end{array}$ & $\begin{array}{l}\text { Inspect and } \\
\text { maintain equipment } \\
\text { Inspect and } \\
\text { maintain equipment } \\
\text { Inspect and } \\
\text { maintain equipment }\end{array}$ \\
\hline FC-3 & $\begin{array}{l}\text { transport return } \\
\text { connection } \\
\mathrm{NC}\end{array}$ & $\begin{array}{l}\text { gas return to the } \\
\text { ullage of the tank } \\
\text { truck when } \\
\text { refueling the } \\
\text { storage tank } \\
\text { Not used in this } \\
\text { mode of operation }\end{array}$ & & & & \\
\hline FC-4 & $\begin{array}{l}\text { transport suction } \\
\text { connection } \\
\text { NC }\end{array}$ & $\begin{array}{l}\text { liquid input for } \\
\text { bottom filling the } \\
\text { storage tank from } \\
\text { tank truck } \\
\text { Not used in this } \\
\text { mode of operation }\end{array}$ & & & & \\
\hline $\overrightarrow{\mathrm{C}}-1$ & $\begin{array}{l}\text { sample cylinder } \\
\text { connection } \\
\mathrm{NC}\end{array}$ & $\begin{array}{l}\text { connection to take } \\
\text { fuel samples to test } \\
\text { for impurities }\end{array}$ & $\begin{array}{l}\text { Incomplete seal } \\
\text { Fail to seal } \\
\text { Fail to detach }\end{array}$ & $\begin{array}{l}\text { foreign material } \\
\text { intrusion (dirt), } \\
\text { operator error } \\
\text { mechanical failure } \\
\text { mechanical failure, } \\
\text { jammed }\end{array}$ & $\begin{array}{l}\text { small LNG release } \\
\text { at ground level } \\
\text { Cannot take LNG } \\
\text { sample } \\
\begin{array}{l}\text { Cannot remove } \\
\text { sample }\end{array}\end{array}$ & $\begin{array}{l}\text { Inspect and } \\
\text { maintain equipment } \\
\text { Inspect and } \\
\text { maintain equipment } \\
\text { Inspect and } \\
\text { maintain equipment }\end{array}$ \\
\hline
\end{tabular}




\begin{tabular}{|c|c|c|c|c|c|c|}
\hline $\mathrm{C}-2$ & $\begin{array}{l}\text { sample vent } \\
\text { connection } \\
\text { NC }\end{array}$ & $\begin{array}{l}\text { connection to vent } \\
\text { off boiling LNG }\end{array}$ & $\begin{array}{l}\text { Incomplete seal } \\
\text { Fail to seal } \\
\text { Fail to detach }\end{array}$ & $\begin{array}{l}\text { foreign material } \\
\text { intrusion (dirt), } \\
\text { operator error } \\
\text { mechanical failure } \\
\text { mechanical failure, } \\
\text { jammed }\end{array}$ & $\begin{array}{l}\text { small LNG release } \\
\text { at ground level } \\
\text { Cannot take LNG } \\
\text { sample } \\
\text { Cannot remove } \\
\text { sample }\end{array}$ & $\begin{array}{l}\text { Inspect and } \\
\text { maintain equipment } \\
\text { Inspect and } \\
\text { maintain equipment } \\
\text { Inspect and } \\
\text { maintain equipment }\end{array}$ \\
\hline $\mathrm{C}-3$ & $\begin{array}{l}\text { sample purge } \\
\text { connection } \\
\mathrm{NC}\end{array}$ & $\begin{array}{l}\text { connection to purge } \\
\text { air from sample } \\
\text { line (using } \\
\text { nitrogen) }\end{array}$ & $\begin{array}{l}\text { Incomplete seal } \\
\text { Fail to seal } \\
\text { Fail to detach }\end{array}$ & $\begin{array}{l}\text { foreign material } \\
\text { intrusion (dirt), } \\
\text { operator error } \\
\text { mechanical failure } \\
\text { mechanical failure, } \\
\text { jammed }\end{array}$ & $\begin{array}{l}\text { may allow air } \\
\text { ingress to } \\
\text { contaminate sample } \\
\text { Cannot take LNG } \\
\text { sample } \\
\text { Cannot remove } \\
\text { nitrogen line from } \\
\text { purge }\end{array}$ & $\begin{array}{l}\text { Inspect and } \\
\text { maintain equipment } \\
\text { Inspect and } \\
\text { maintain equipment } \\
\text { Inspect and } \\
\text { maintain equipment }\end{array}$ \\
\hline $\mathrm{C}-4$ & $\begin{array}{l}\text { vehicle vent } \\
\text { connection } \\
\text { NC }\end{array}$ & $\begin{array}{l}\text { connection to end } \\
\text { use vehicle to vent } \\
\text { the vehicle fuel } \\
\text { tank gas into } \\
\text { pressure tank ullage }\end{array}$ & $\begin{array}{l}\text { Incomplete seal } \\
\text { Fail to seal } \\
\text { Fail to detach }\end{array}$ & $\begin{array}{l}\text { foreign material } \\
\text { intrusion (dirt), ice } \\
\text { buildup, operator } \\
\text { error } \\
\text { mechanical failure } \\
\\
\text { mechanical failure, } \\
\text { jammed }\end{array}$ & $\begin{array}{l}\text { small gas release at } \\
\text { ground level } \\
\text { vent EUV gas from } \\
\text { tank at ground level } \\
\text { or cannot fill EUV } \\
\text { tank } \\
\text { Cannot remove } \\
\text { EUV, stops } \\
\text { operation }\end{array}$ & $\begin{array}{l}\text { Inspect and } \\
\text { maintain equipment } \\
\text { Inspect and } \\
\text { maintain equipment } \\
\text { Inspect and } \\
\text { maintain equipment }\end{array}$ \\
\hline C-5 & $\begin{array}{l}\text { N2 purge } \\
\text { connection } \\
\text { NC }\end{array}$ & $\begin{array}{l}\text { connection to } \\
\text { sweep nitrogen gas } \\
\text { when purging tank } \\
\text { of condensables }\end{array}$ & $\begin{array}{l}\text { Incomplete seal } \\
\text { Fail to seal } \\
\text { Fail to detach } \\
\end{array}$ & $\begin{array}{l}\text { foreign material } \\
\text { intrusion (dirt), } \\
\text { operator error } \\
\text { mechanical failure } \\
\text { mechanical failure, } \\
\text { jammed }\end{array}$ & $\begin{array}{l}\text { small LNG release } \\
\text { at ground level } \\
\text { Cannot take LNG } \\
\text { sample } \\
\text { Cannot remove } \\
\text { sample }\end{array}$ & $\begin{array}{l}\text { Inspect and } \\
\text { maintain equipment } \\
\text { Inspect and } \\
\text { maintain equipment } \\
\text { Inspect and } \\
\text { maintain equipment }\end{array}$ \\
\hline
\end{tabular}




\begin{tabular}{|c|c|c|c|c|c|c|}
\hline PT (assumed) & pressure tank & $\begin{array}{l}\text { vacuum insulated } \\
\text { tank, houses } \\
\text { transfer pump for } \\
\text { LNG transfer }\end{array}$ & $\begin{array}{l}\text { Outer wall leak } \\
\text { Outer wall failure } \\
\text { Inner wall leak } \\
\text { Inner wall failure }\end{array}$ & $\begin{array}{l}\text { fatigue crack, } \\
\text { weld flaw } \\
\text { large crack or weld } \\
\text { failure } \\
\text { fatigue crack, } \\
\text { weld flaw } \\
\text { large crack or weld } \\
\text { failure }\end{array}$ & \begin{tabular}{|l} 
air admission, LNG \\
boiloff rate is high \\
air admission, LNG \\
boils \\
gas admission to \\
annulus, LNG \\
boiloff rate \\
increases \\
gas admission to \\
annulus, LNG \\
boils \\
\end{tabular} & $\begin{array}{l}\text { venting to storage } \\
\text { tank is high } \\
\text { overpressure relief } \\
\text { valves } \\
\text { venting to storage } \\
\text { tank is high } \\
\text { overpressure relief } \\
\text { valves }\end{array}$ \\
\hline ST (assumed) & storage tank & $\begin{array}{l}\text { vacuum insulated } \\
\text { tank, contains LNG } \\
\text { for storage until } \\
\text { dispensed to end use } \\
\text { vehicles }\end{array}$ & $\begin{array}{l}\text { Outer wall leak } \\
\text { Outer wall failure } \\
\text { Inner wall leak } \\
\text { Inner wall failure }\end{array}$ & $\begin{array}{l}\text { fatigue crack, } \\
\text { weld flaw } \\
\text { large crack or weld } \\
\text { failure } \\
\text { fatigue crack, } \\
\text { weld flaw } \\
\text { large crack or weld } \\
\text { failure }\end{array}$ & $\begin{array}{l}\text { air admission, LNG } \\
\text { boiloff raie is high } \\
\text { air admission, LNG } \\
\text { boils } \\
\text { gas admission to } \\
\text { annulus, LNG } \\
\text { boiloff rate } \\
\text { increases } \\
\text { gas admission to } \\
\text { annulus, LNG } \\
\text { boils }\end{array}$ & $\begin{array}{l}\text { venting to storage } \\
\text { tank is high } \\
\text { overpressure relief } \\
\text { valves } \\
\text { venting to storage } \\
\text { tank is high } \\
\text { overpressure relief } \\
\text { valves }\end{array}$ \\
\hline
\end{tabular}




\begin{tabular}{|c|c|c|c|c|c|c|}
\hline JFP & $\begin{array}{l}\text { jacketed fill piping } \\
\text { (ST to PT, } \\
\text { assumed designator) }\end{array}$ & $\begin{array}{l}\text { Insulated piping to } \\
\text { route LNG from } \\
\text { storage to pump, } \\
\text { may be vacuum } \\
\text { jacketed pipe }\end{array}$ & $\begin{array}{l}\text { Outer wall leak } \\
\text { Outer wall failure } \\
\text { Inner wall leak } \\
\text { Inner wall failure } \\
\text { Plugging }\end{array}$ & $\begin{array}{l}\text { fatigue crack, } \\
\text { weld flaw } \\
\text { large crack or weld } \\
\text { failure } \\
\text { fatigue crack, } \\
\text { weld flaw } \\
\text { large crack or weld } \\
\text { failure } \\
\text { hydrates, ice } \\
\text { buildup }\end{array}$ & $\begin{array}{l}\text { air admission, LNG } \\
\text { boiloff rate is high } \\
\text { air admission, LNG } \\
\text { boils } \\
\text { gas admission to } \\
\text { annulus, LNG } \\
\text { boiloff rate } \\
\text { increases } \\
\text { gas admission to } \\
\text { annulus, LNG } \\
\text { boils } \\
\text { Flow stops, } \\
\text { operation is halted } \\
\text { until repairs are } \\
\text { made }\end{array}$ & $\begin{array}{l}\text { venting to storage } \\
\text { tank is high } \\
\text { overpressure relief } \\
\text { valves } \\
\text { venting to storage } \\
\text { tank is high } \\
\text { overpressure relief } \\
\text { valves } \\
\text { Must be repaired to } \\
\text { operate again }\end{array}$ \\
\hline
\end{tabular}




\begin{tabular}{|c|c|c|c|c|c|c|}
\hline other piping & assumed designator & $\begin{array}{l}\text { piping for } \\
\text { instruments, relief } \\
\text { valves, and for gas } \\
\text { flow }\end{array}$ & $\begin{array}{l}\text { External leak } \\
\text { Rupture } \\
\text { Plugging }\end{array}$ & $\begin{array}{l}\text { fatigue crack, } \\
\text { weld flaw } \\
\text { large crack or weld } \\
\text { failure } \\
\text { foreign material, } \\
\text { hydrates, ice, etc. }\end{array}$ & $\begin{array}{l}\text { gas release at } \\
\text { ground level } \\
\text { large gas release at } \\
\text { ground level } \\
\text { no flow, valves or } \\
\text { instruments may be } \\
\text { isolated }\end{array}$ & $\begin{array}{l}\text { sensors detect gas } \\
\text { release } \\
\text { sensors detect gas } \\
\text { release } \\
\text { Disrupts operation, } \\
\text { must repair. } \\
\text { Inspect and } \\
\text { maintain system. }\end{array}$ \\
\hline Bund & metal bund wall & $\begin{array}{l}\text { a dike built around } \\
\text { all of the equipment } \\
\text { to confine large } \\
\text { spills of LNG }\end{array}$ & $\begin{array}{l}\begin{array}{l}\text { Foreign material } \\
\text { intrusion }\end{array} \\
\text { External leak } \\
\text { Rupture }\end{array}$ & $\begin{array}{l}\text { debris from area } \\
\text { (leaves, paper, bird } \\
\text { nests, snow,. etc.) } \\
\text { crack, impact } \\
\text { severe impact }\end{array}$ & $\begin{array}{l}\text { could allow large } \\
\text { liquid release to } \\
\text { overflow wall. } \\
\text { Also a fire hazard. } \\
\text { would aliow part of } \\
\text { a large liquid } \\
\text { release onto ground } \\
\text { would allow most } \\
\text { of a large liquid } \\
\text { release to flow onto } \\
\text { the ground }\end{array}$ & $\begin{array}{l}\text { Use pathway } \\
\text { markings and } \\
\text { collision barriers } \\
\text { Use sturdy } \\
\text { collision barriers }\end{array}$ \\
\hline
\end{tabular}

Note: EUV is end use vehicle

ST is storage tank

PT is pressure tank that houses the pump and meter 
Appendix B - Fault Trees for Initiating Events

B-1 

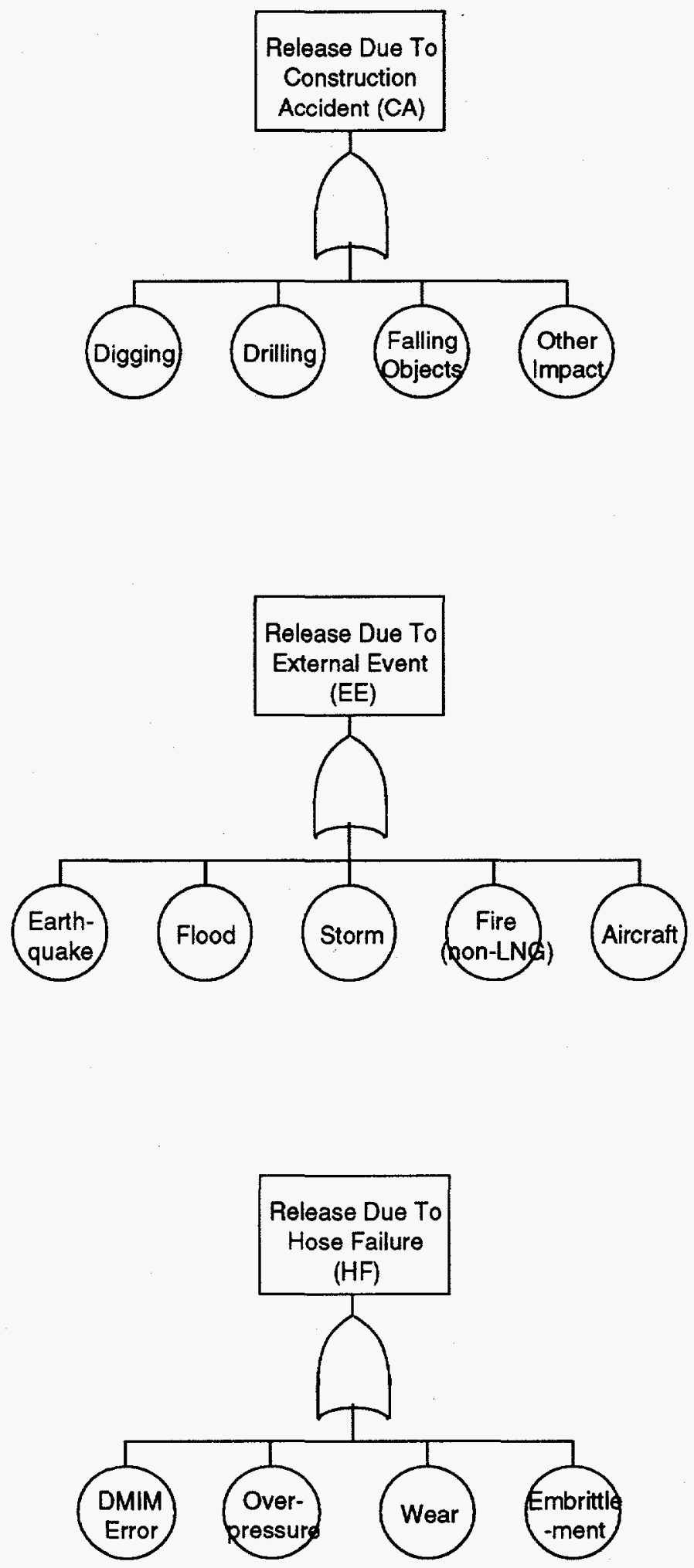

B-2 


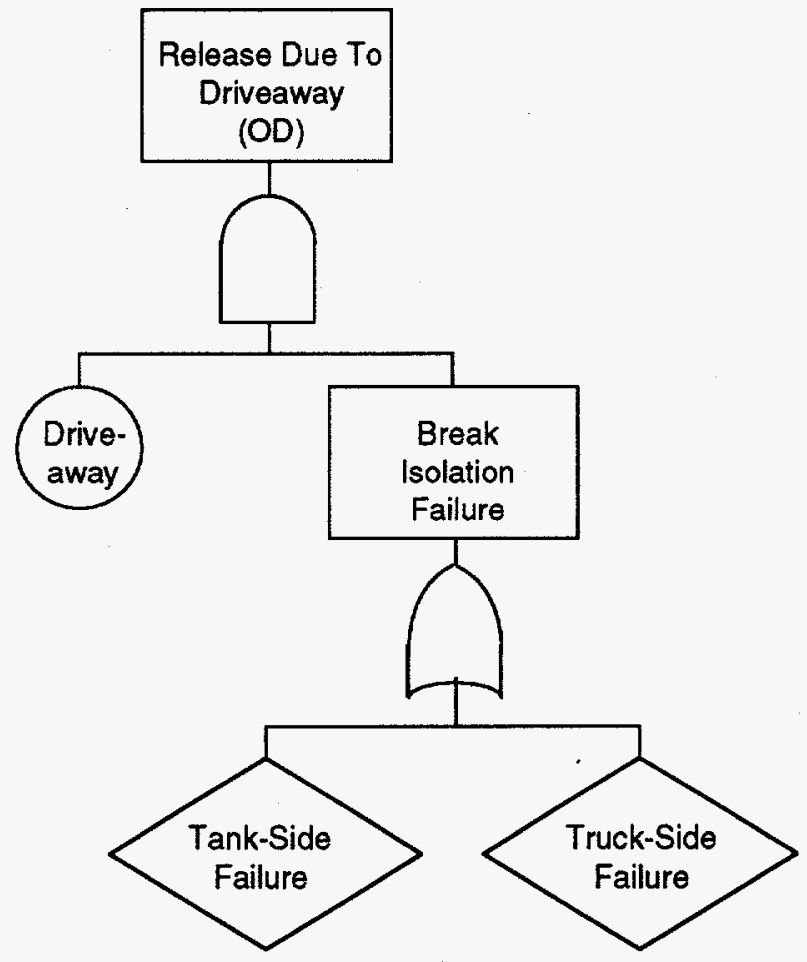

B-3 


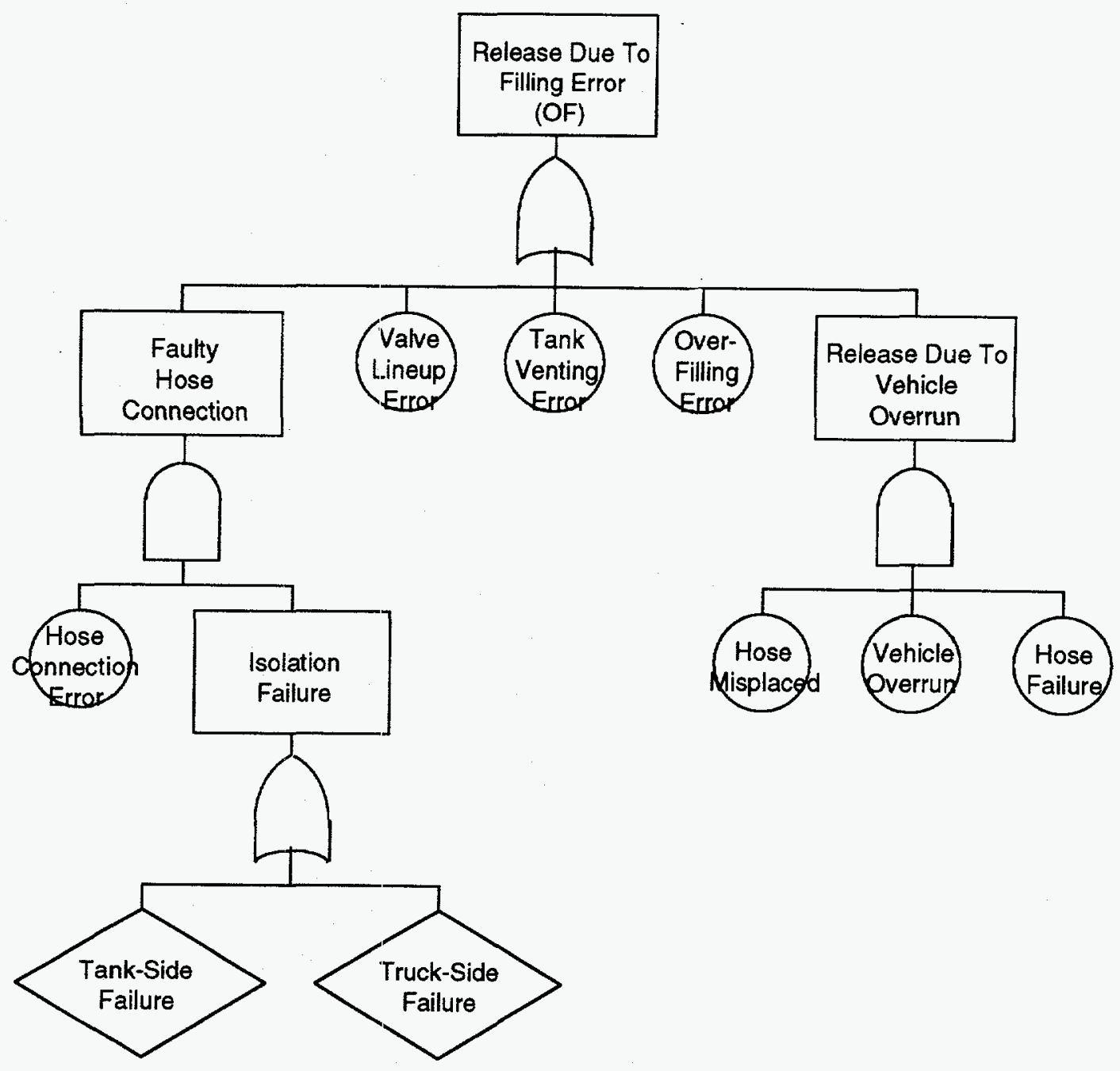



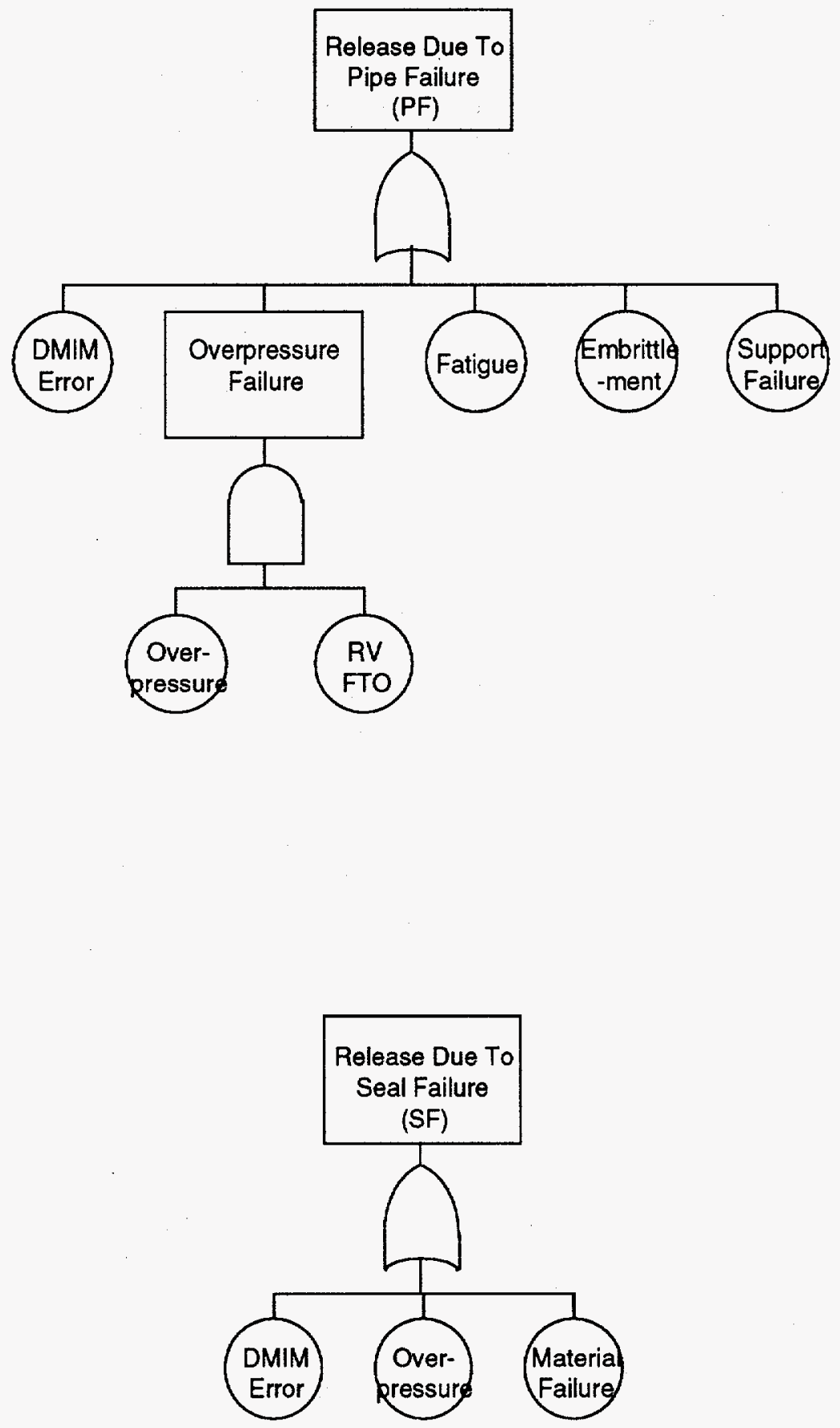

B-5 

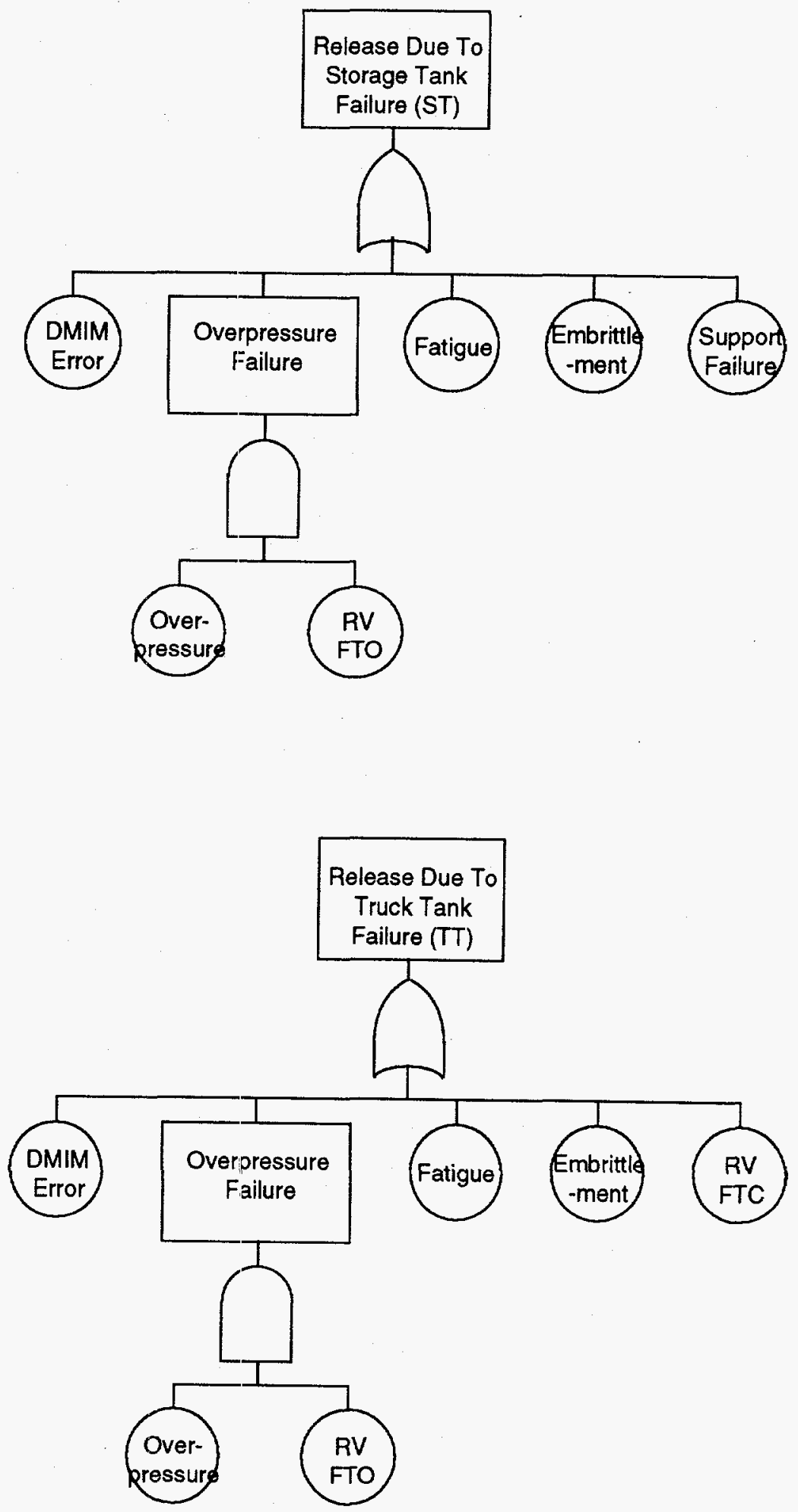

B-6 

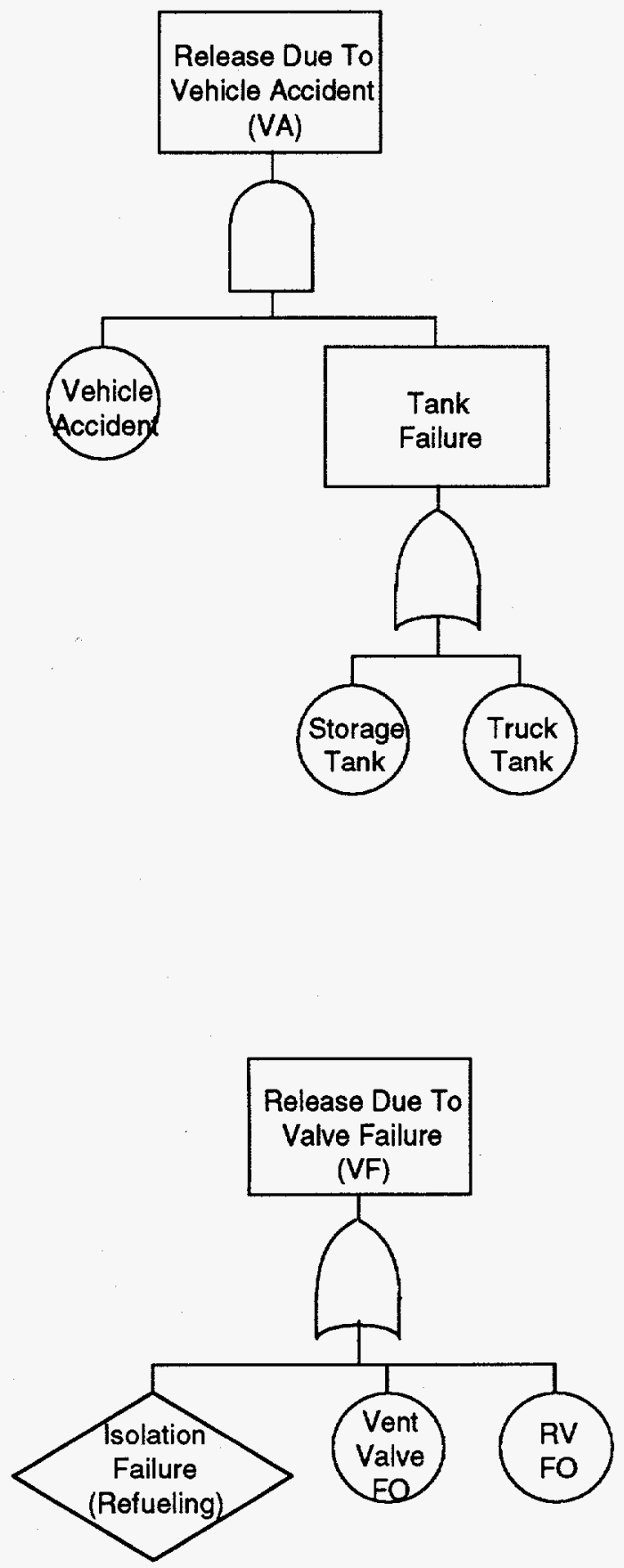
Appendix C - Event Trees for Refueling Station Qualitative Risk Assessment

C-1 


\begin{tabular}{|c|c|}
\hline 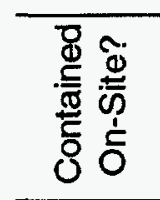 & 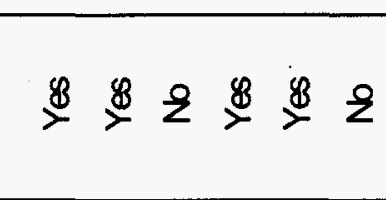 \\
\hline 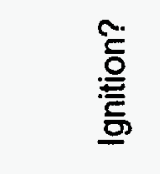 & $z z z z \frac{8}{>} \frac{8}{>}$ \\
\hline 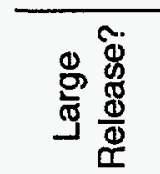 & 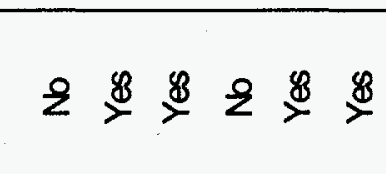 \\
\hline
\end{tabular}

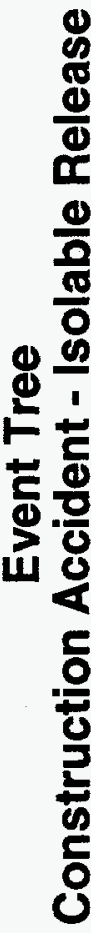
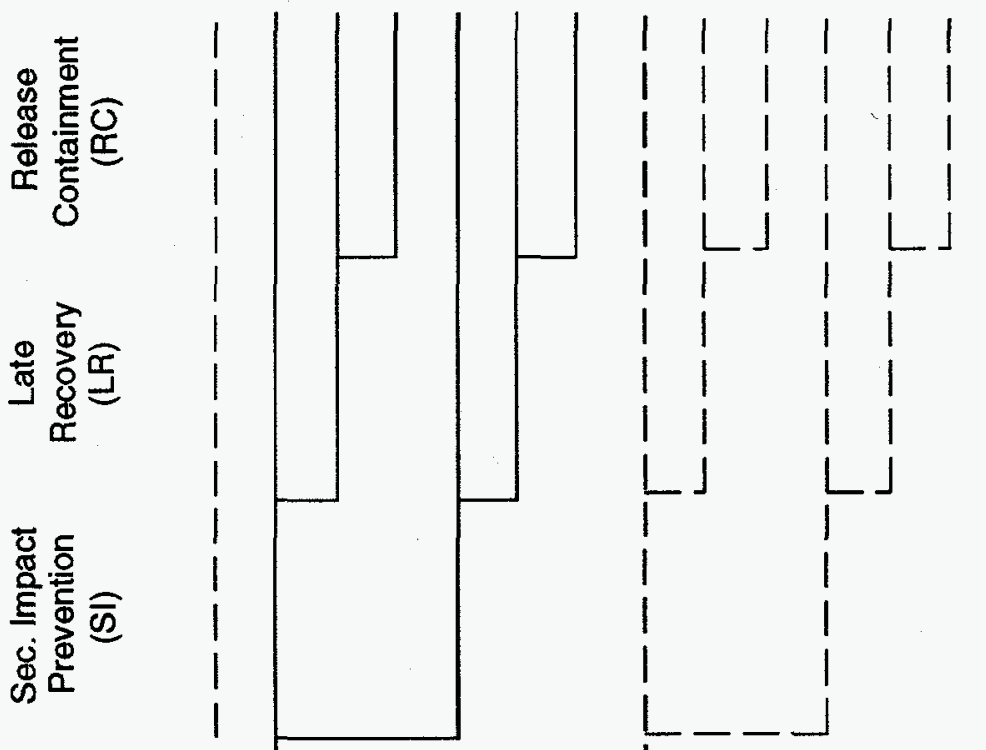

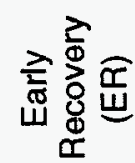

窟婄

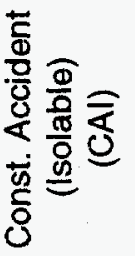

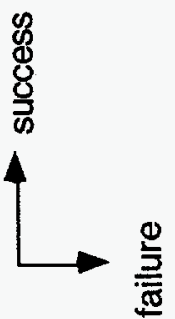

C-2 


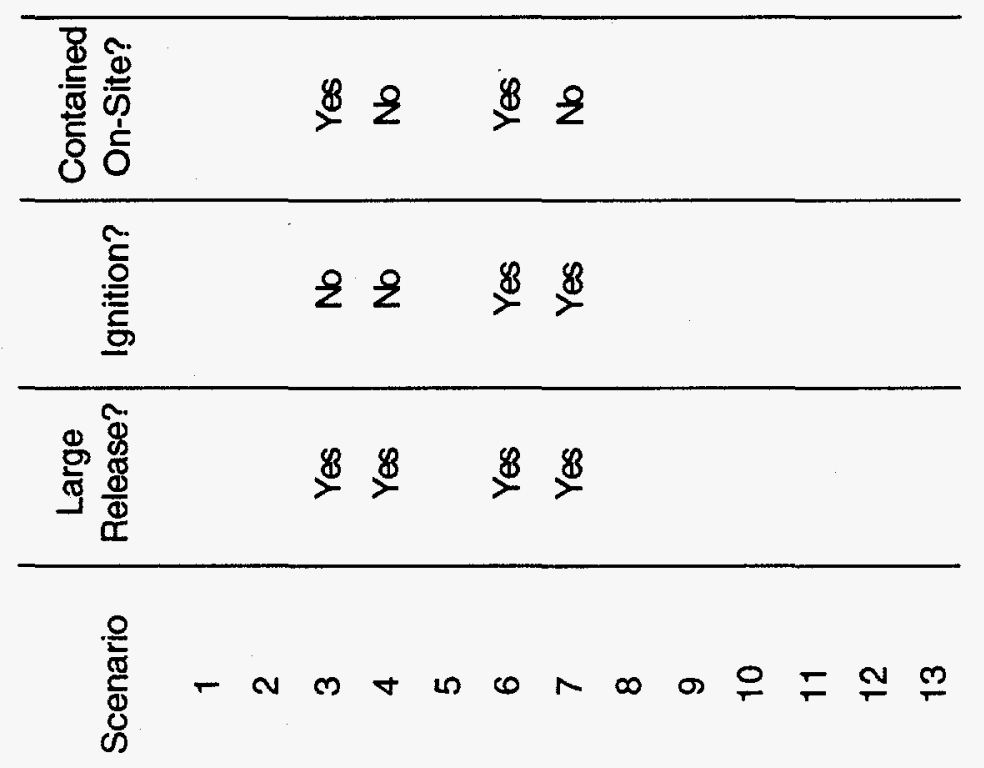

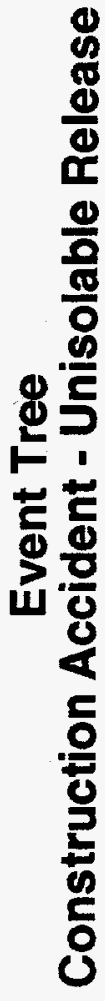

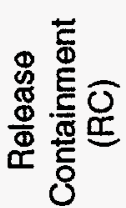

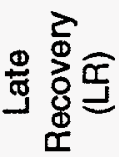

हू

फ

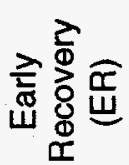

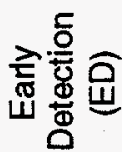

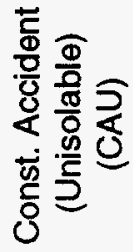

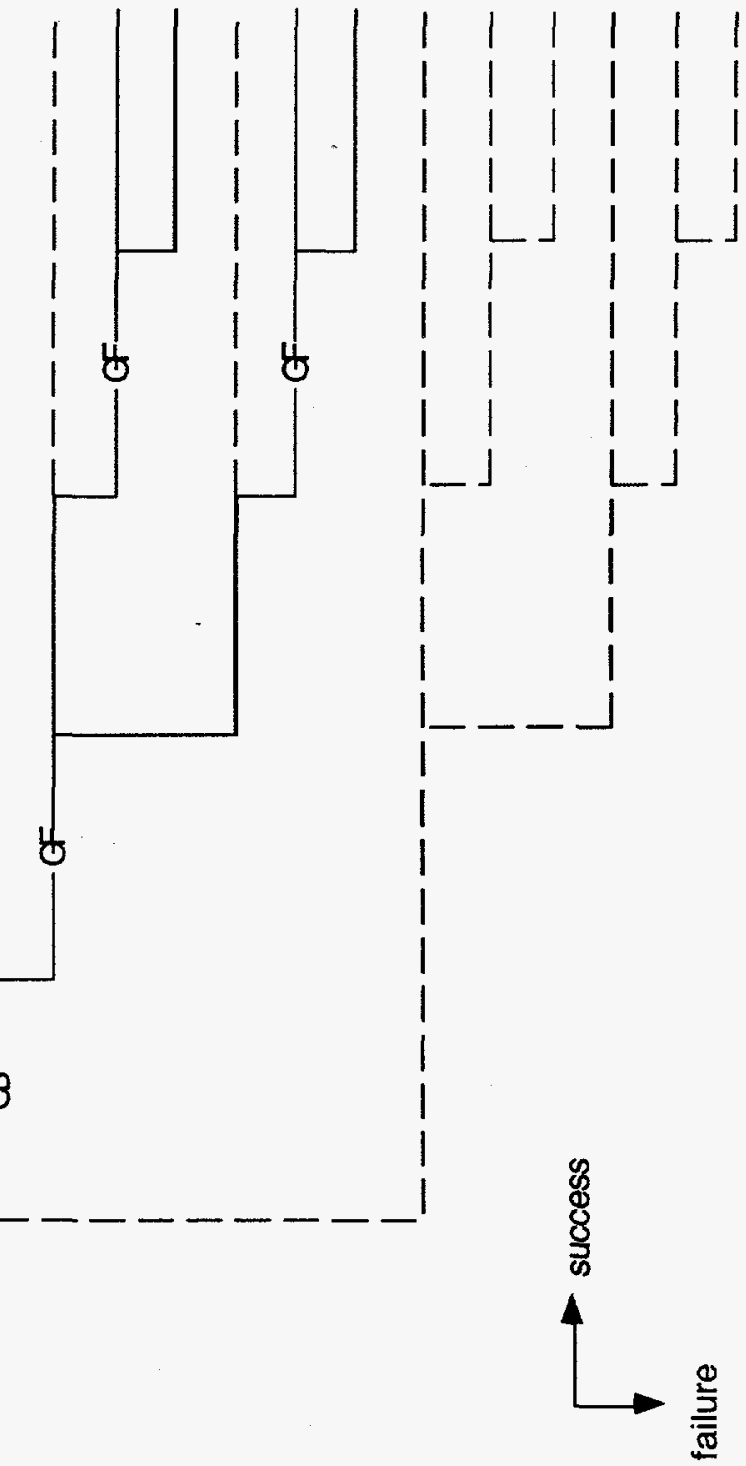




\section{Event Tree \\ External Events}

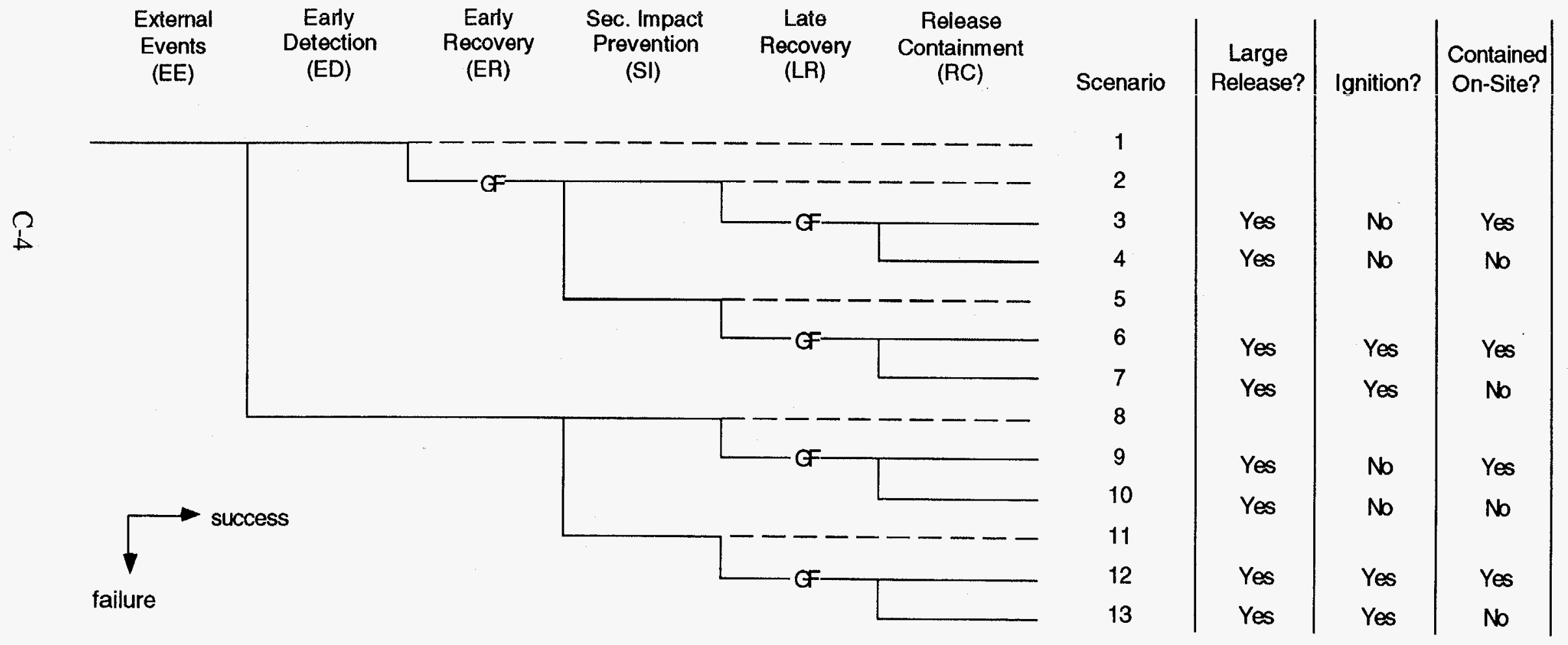




\section{Event Tree \\ Hose Failure}

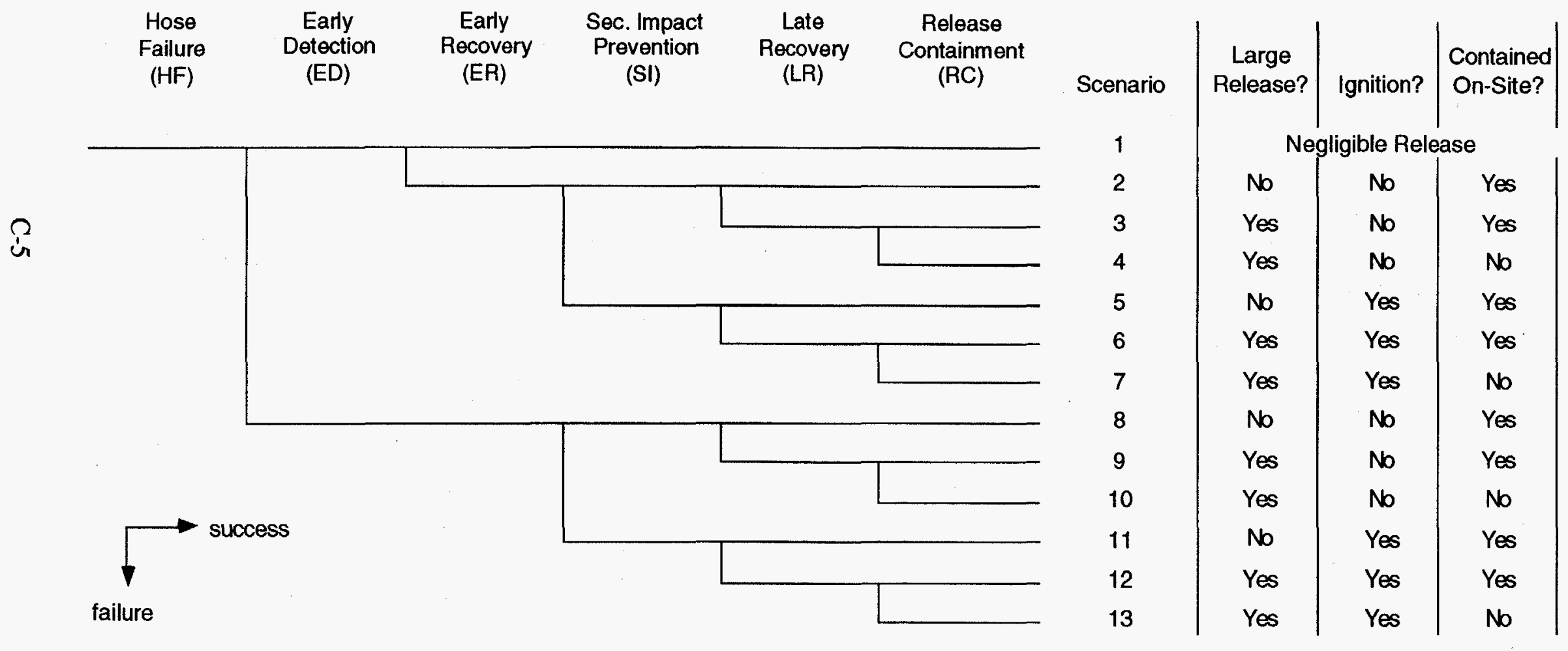




\section{Event Tree}

Driveaway

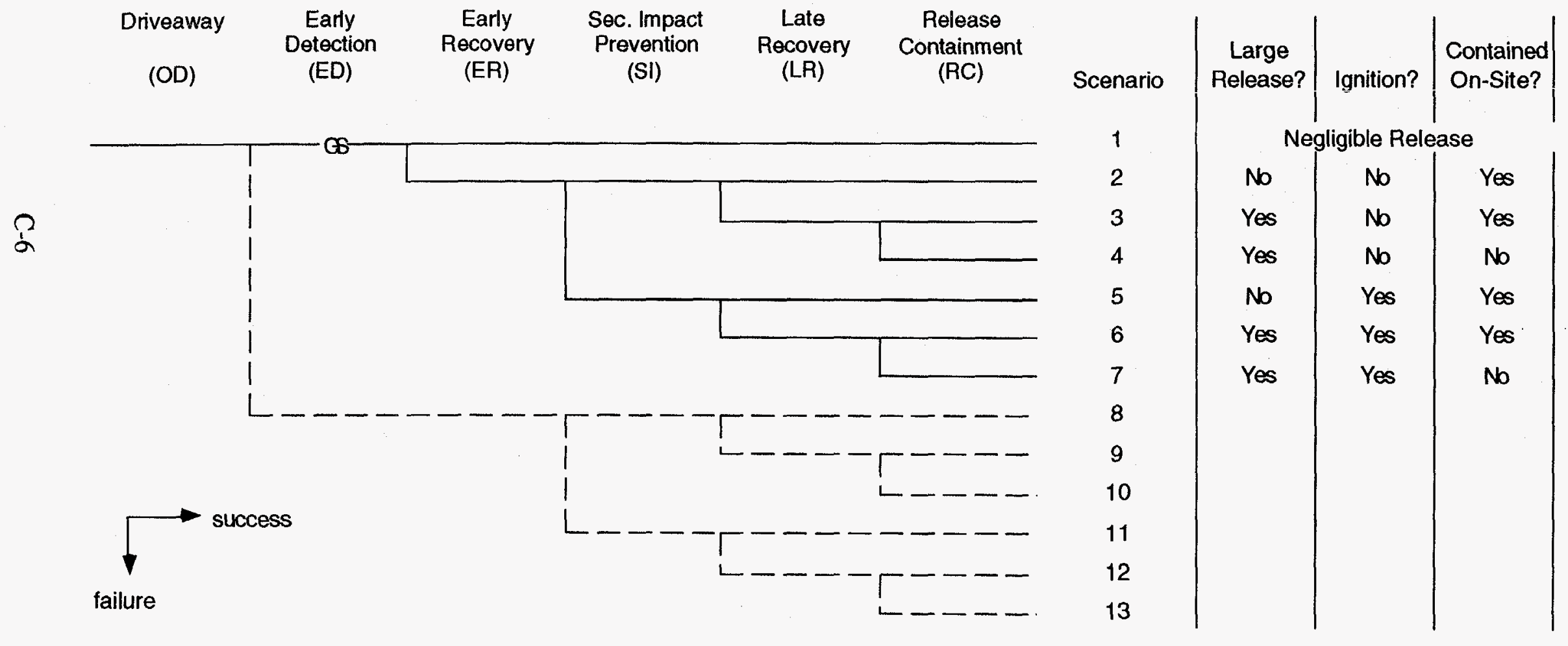




\section{Event Tree \\ Tank Filling Error}

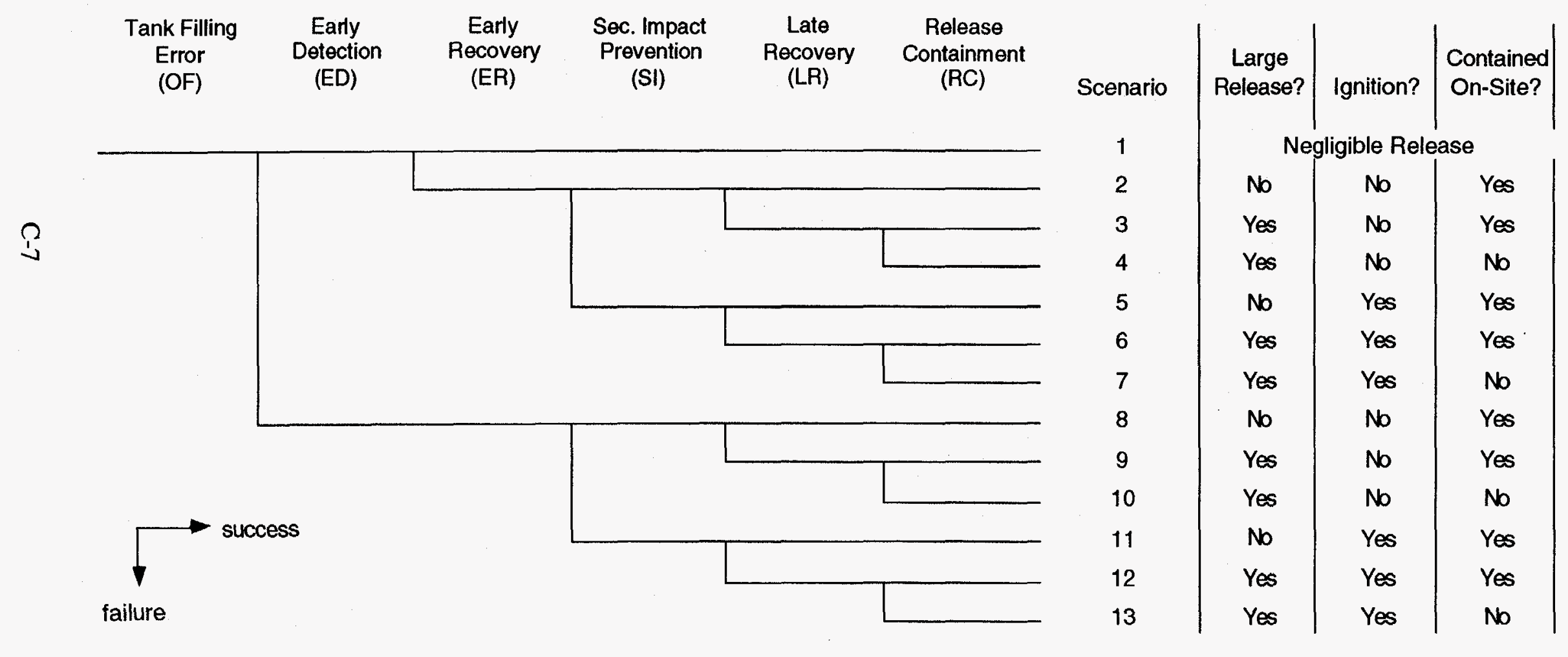




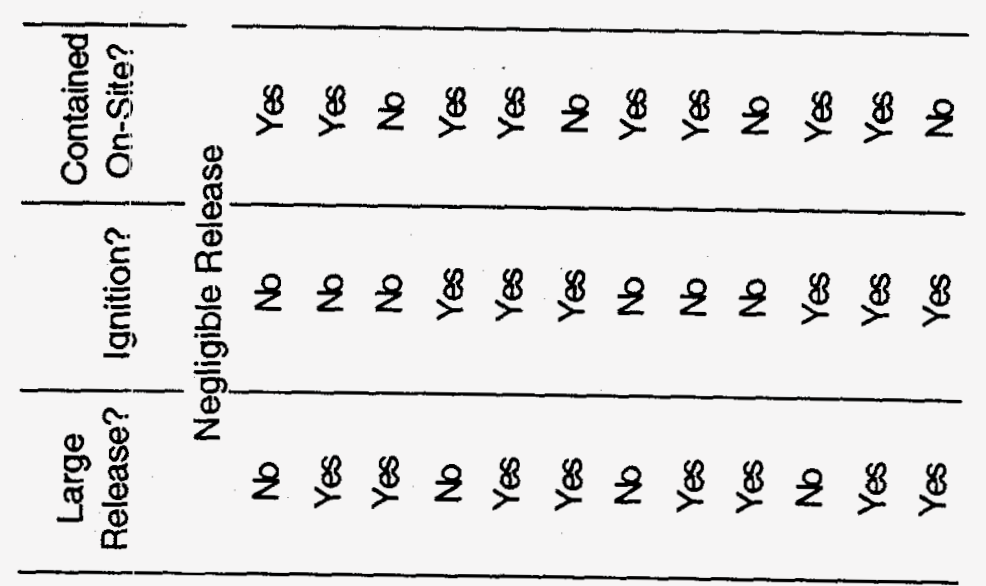
営

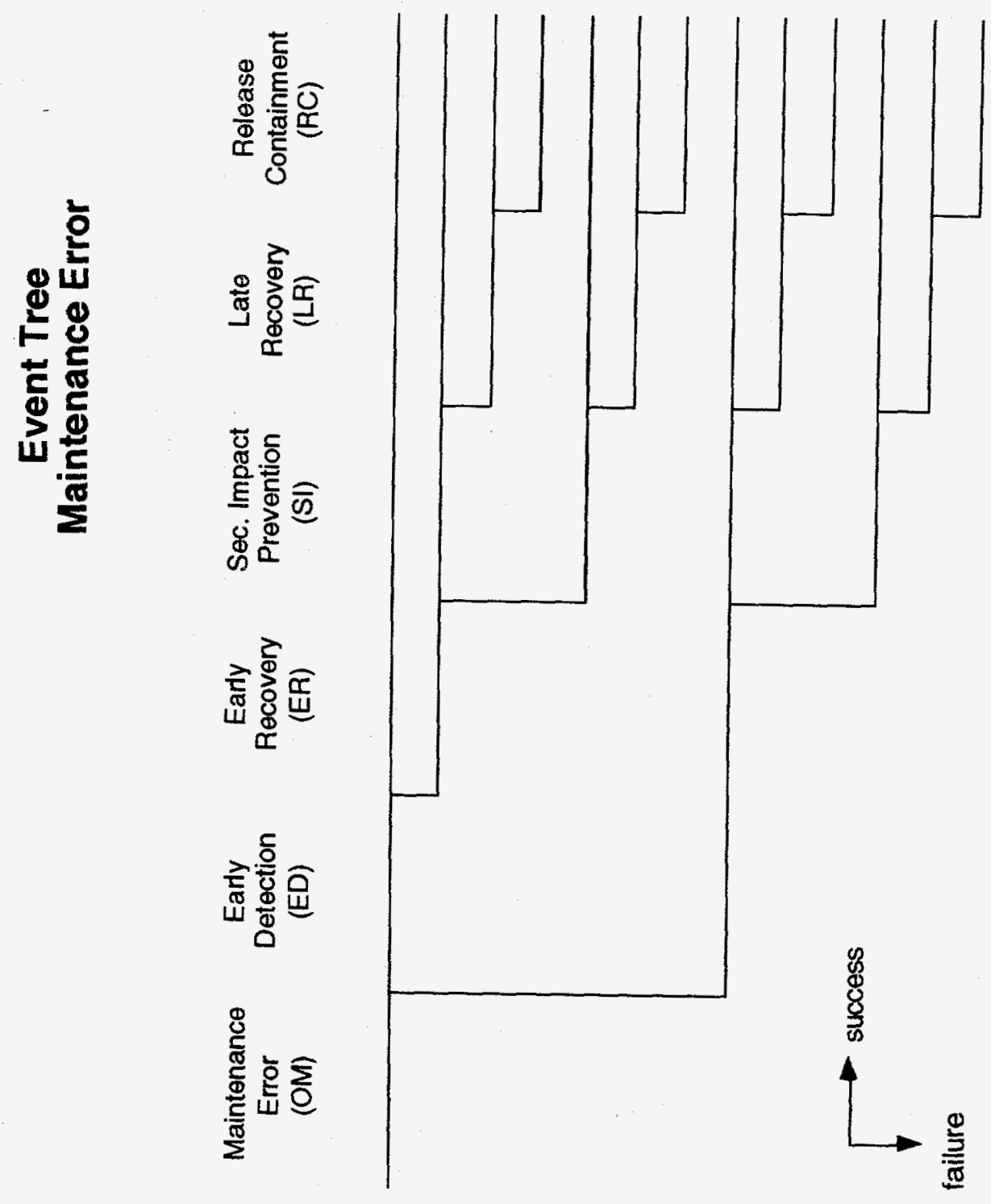




\section{Event Tree \\ Pipe Failure - Isolable}

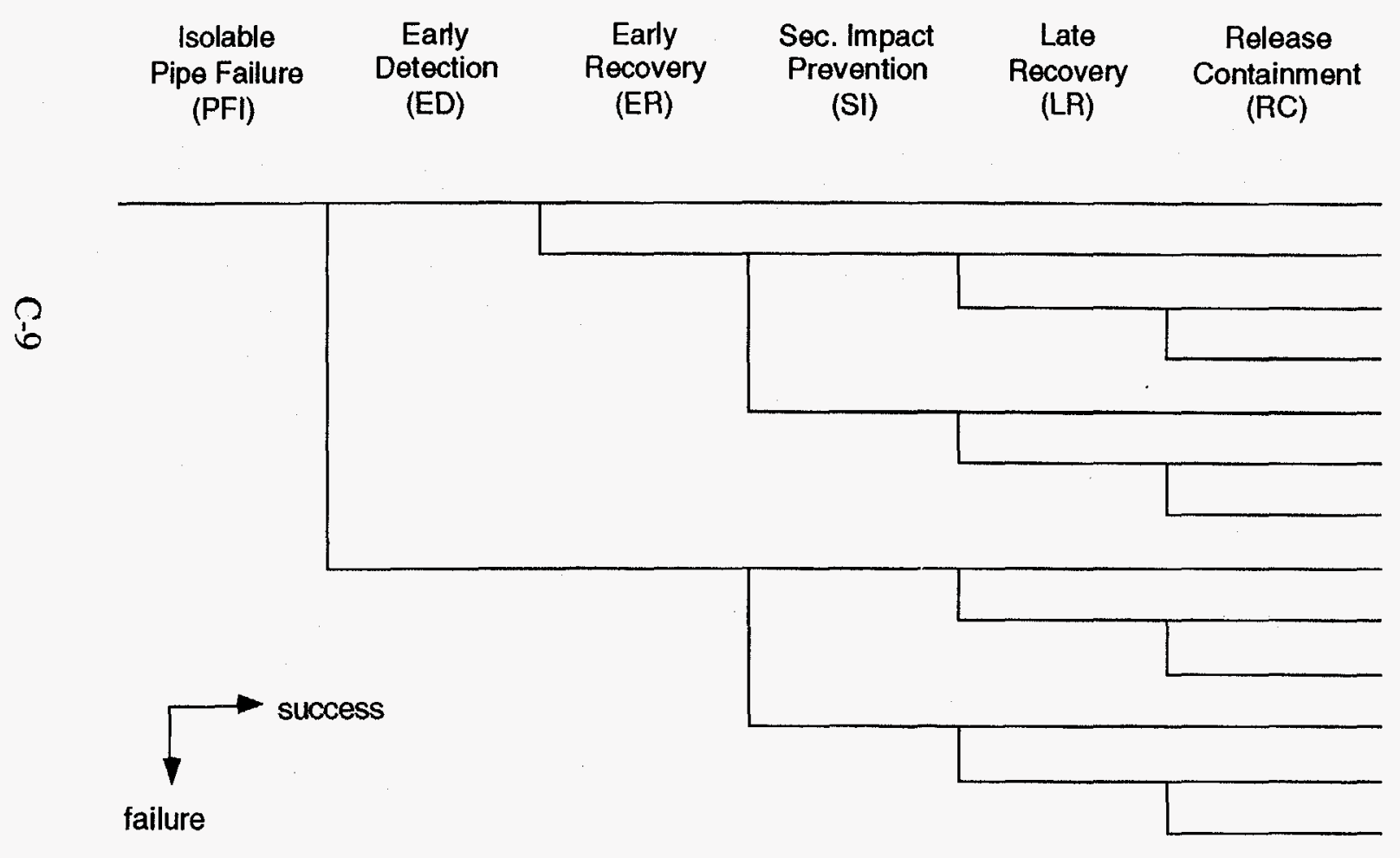

\begin{tabular}{c|c|c|c|} 
Scenario & $\begin{array}{c}\text { Large } \\
\text { Release? }\end{array}$ & Ignition? & Contained \\
On-Site?
\end{tabular}




\section{Event Tree \\ Pipe Failure - Unisolable}

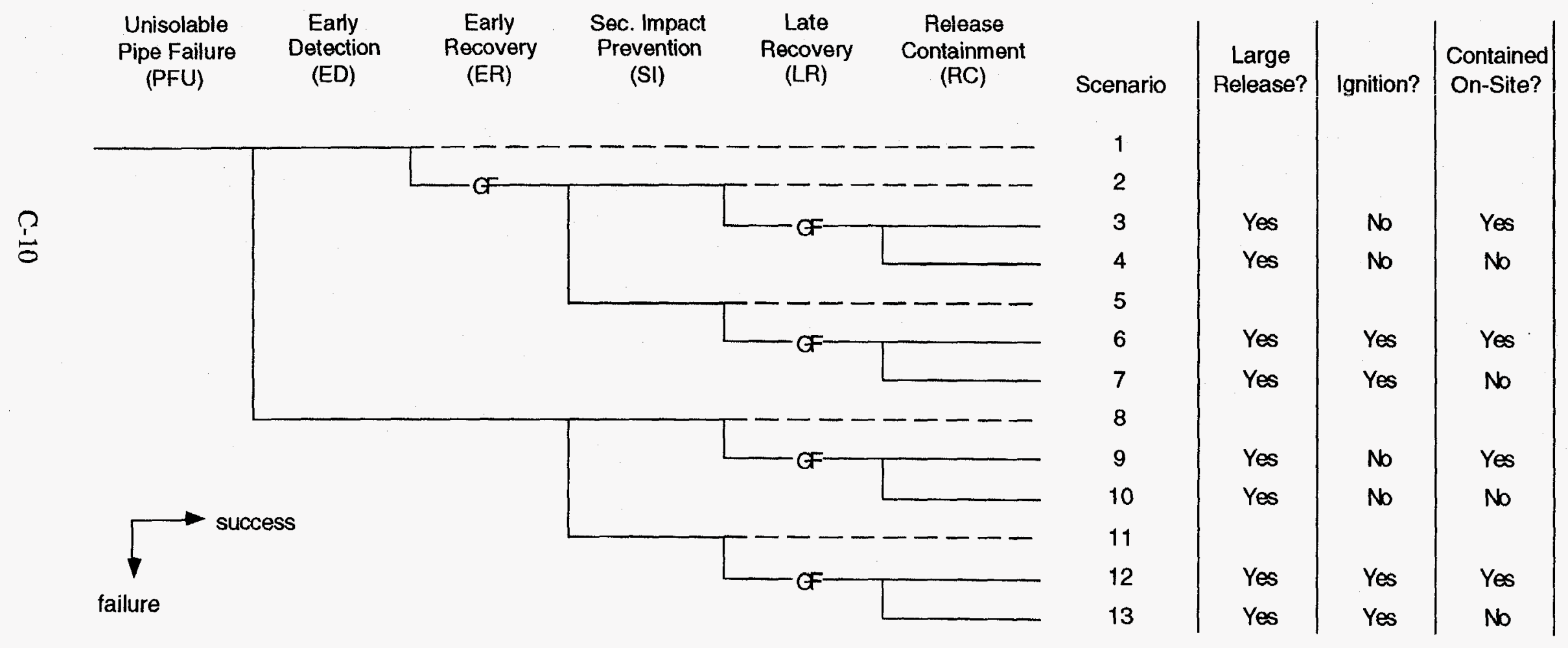




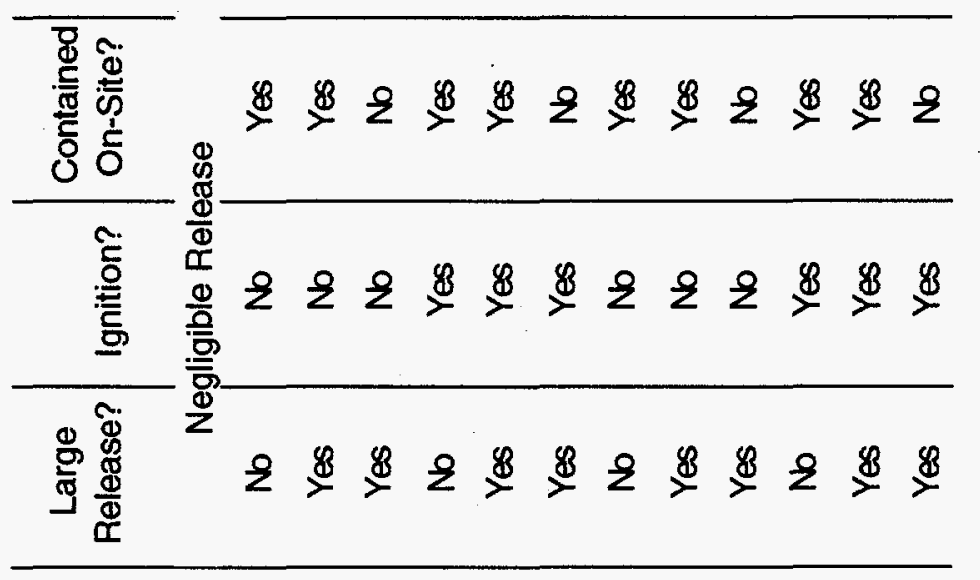

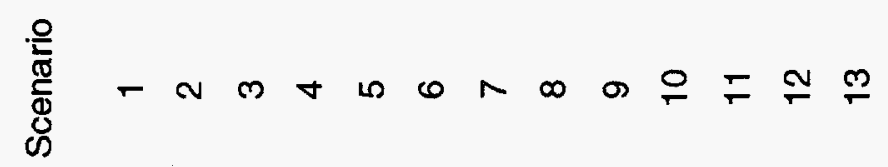

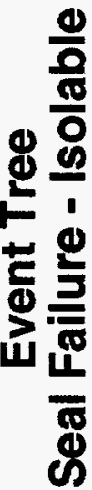

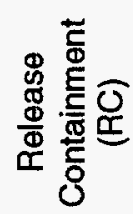

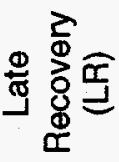

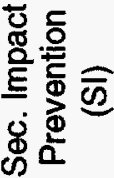

离密兽出

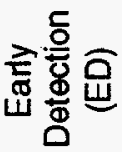

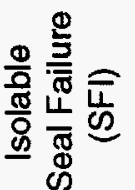

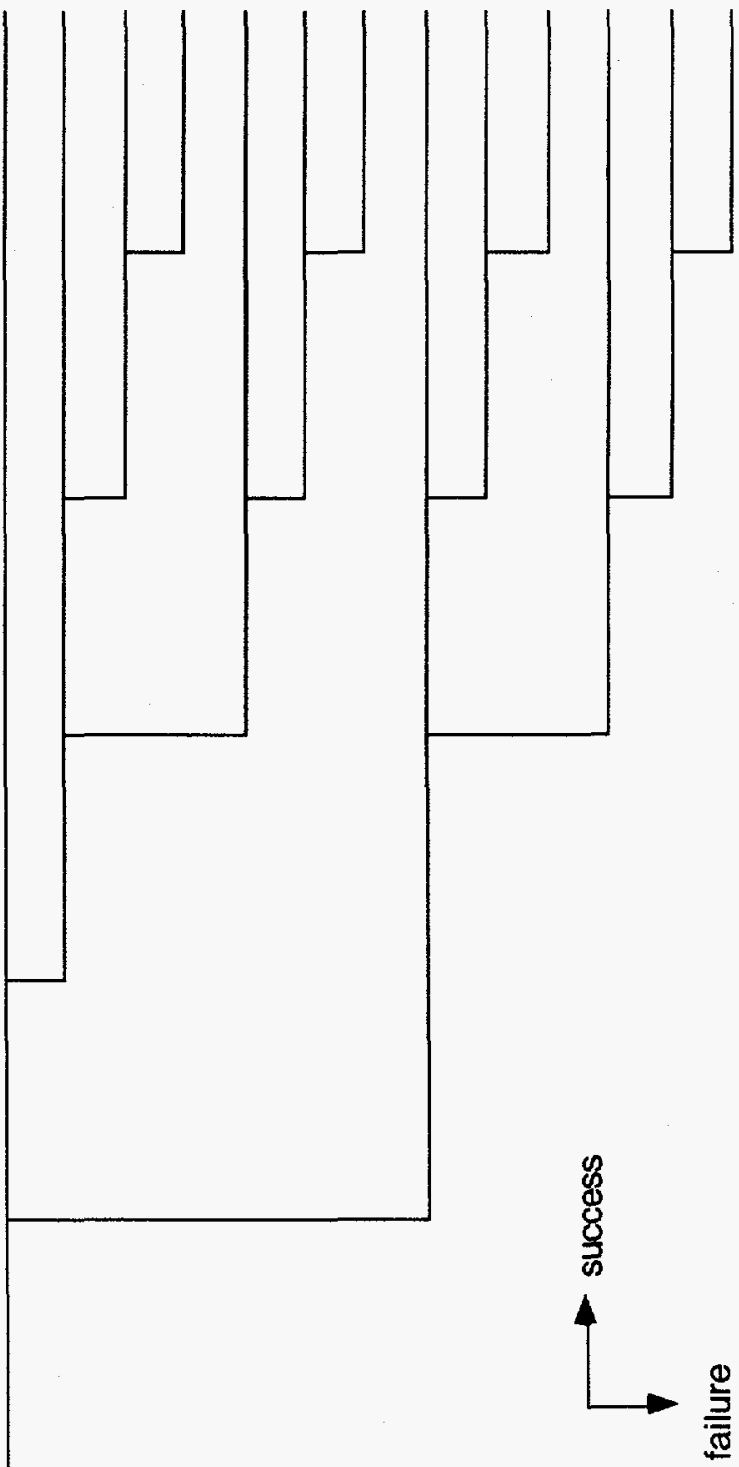

C-11 


\section{Event Tree \\ Seal Failure - Unisolable}

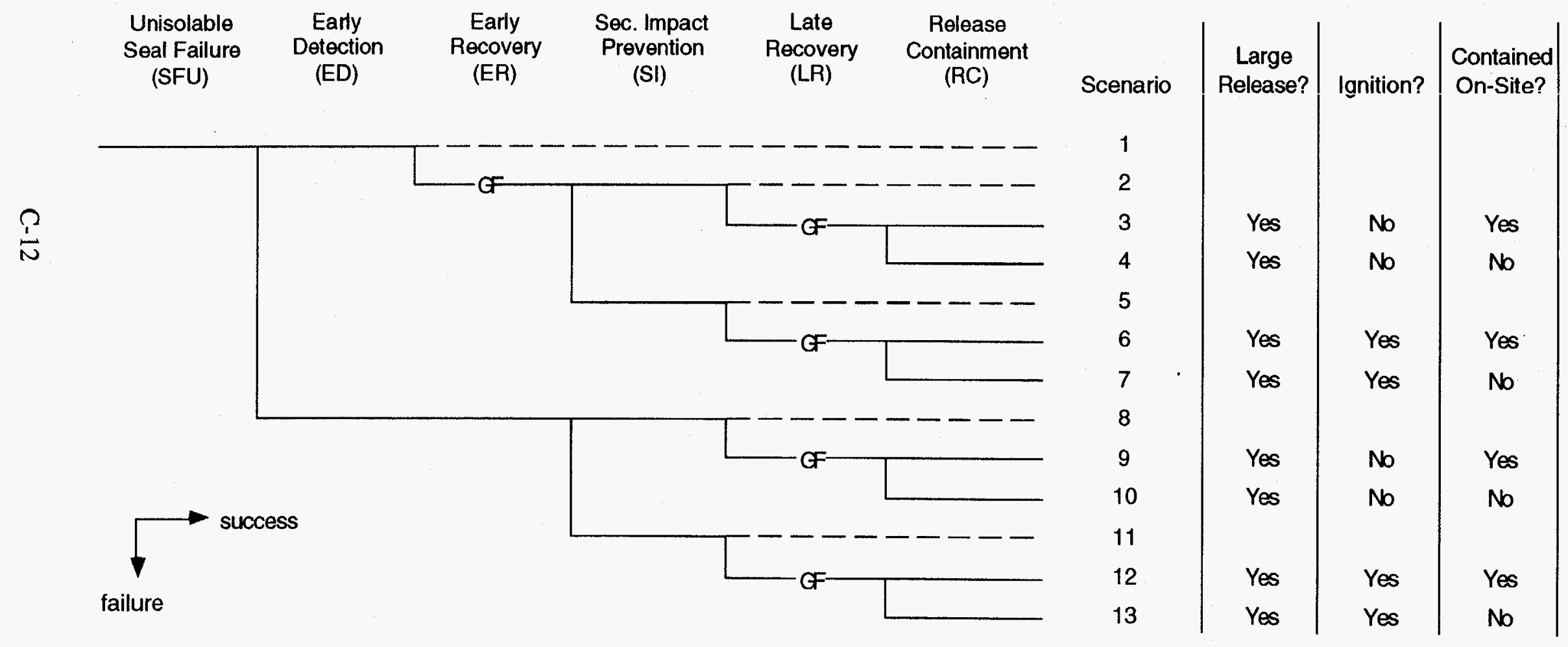




\section{Event Tree \\ Storage Tank Failure}

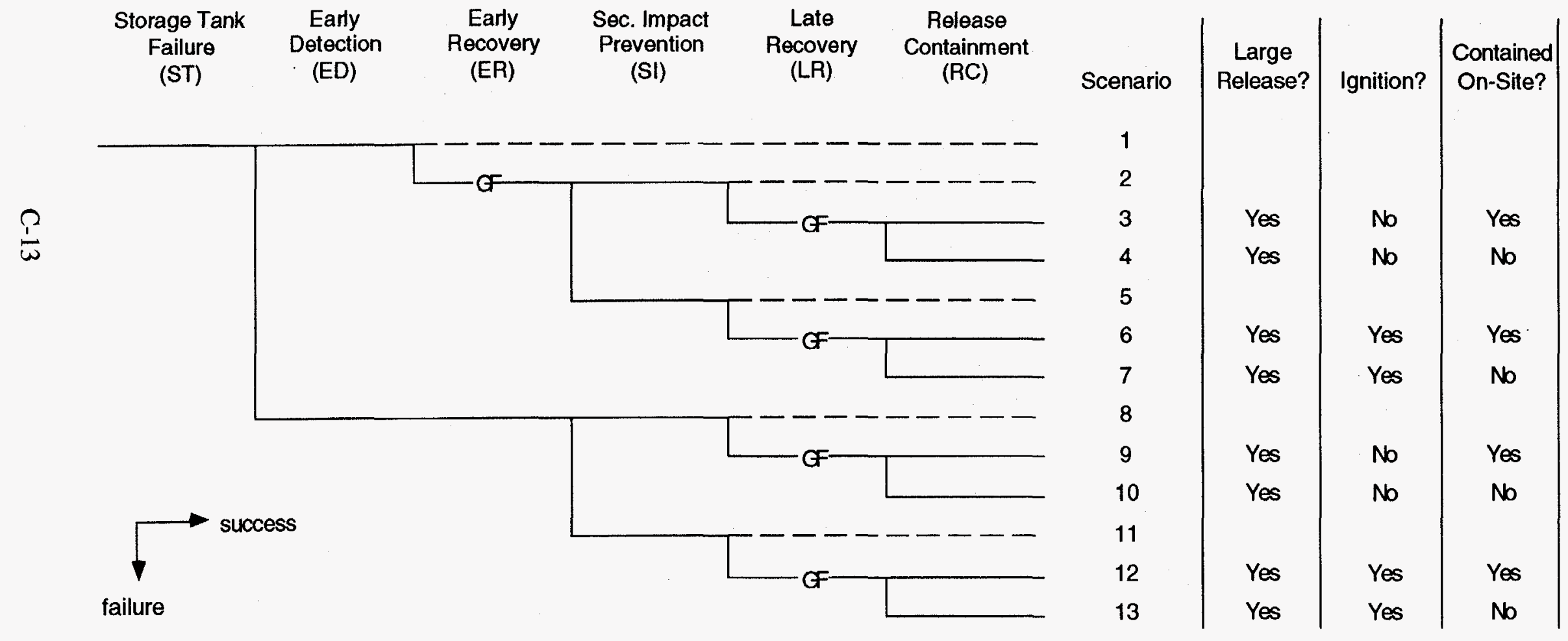




\section{Event Tree \\ Truck Fuel Tank Failure}

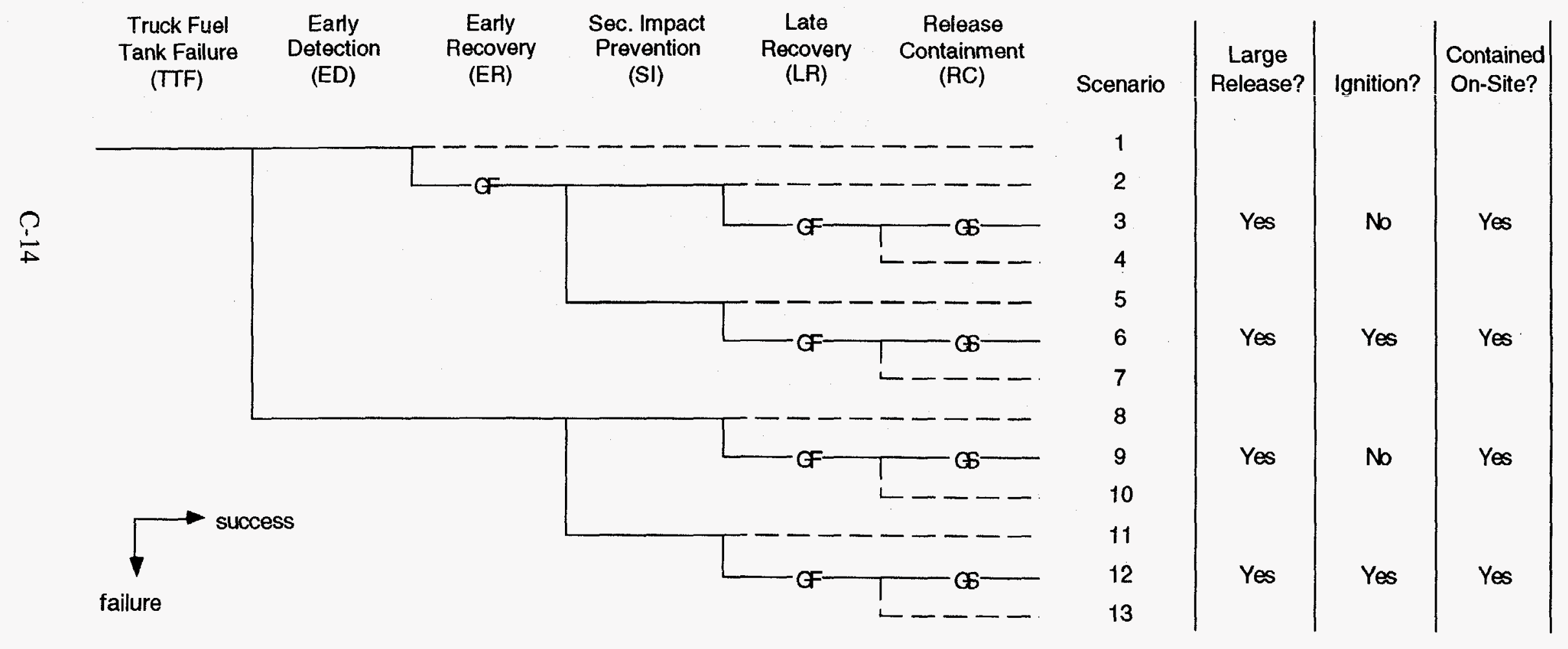




\section{Event Tree}

Tanker Truck Failure

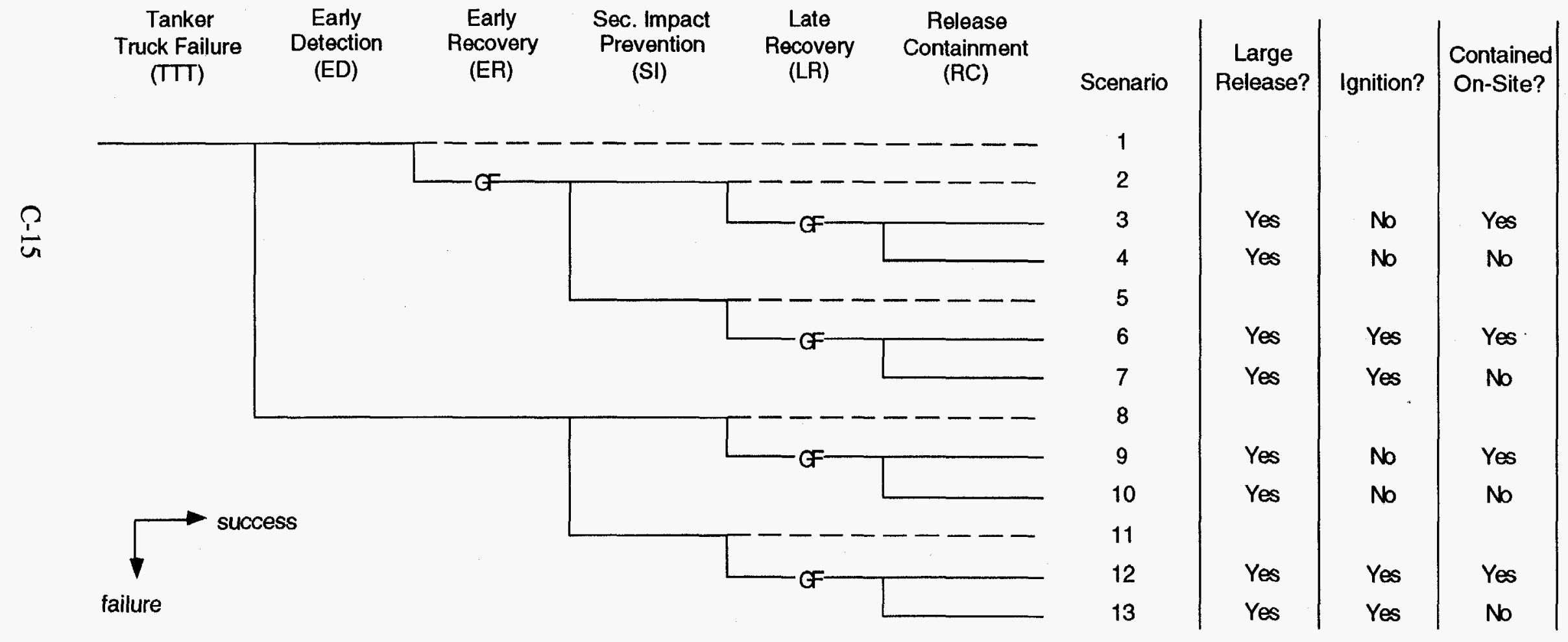




\section{Event Tree \\ Vehicle Accident}

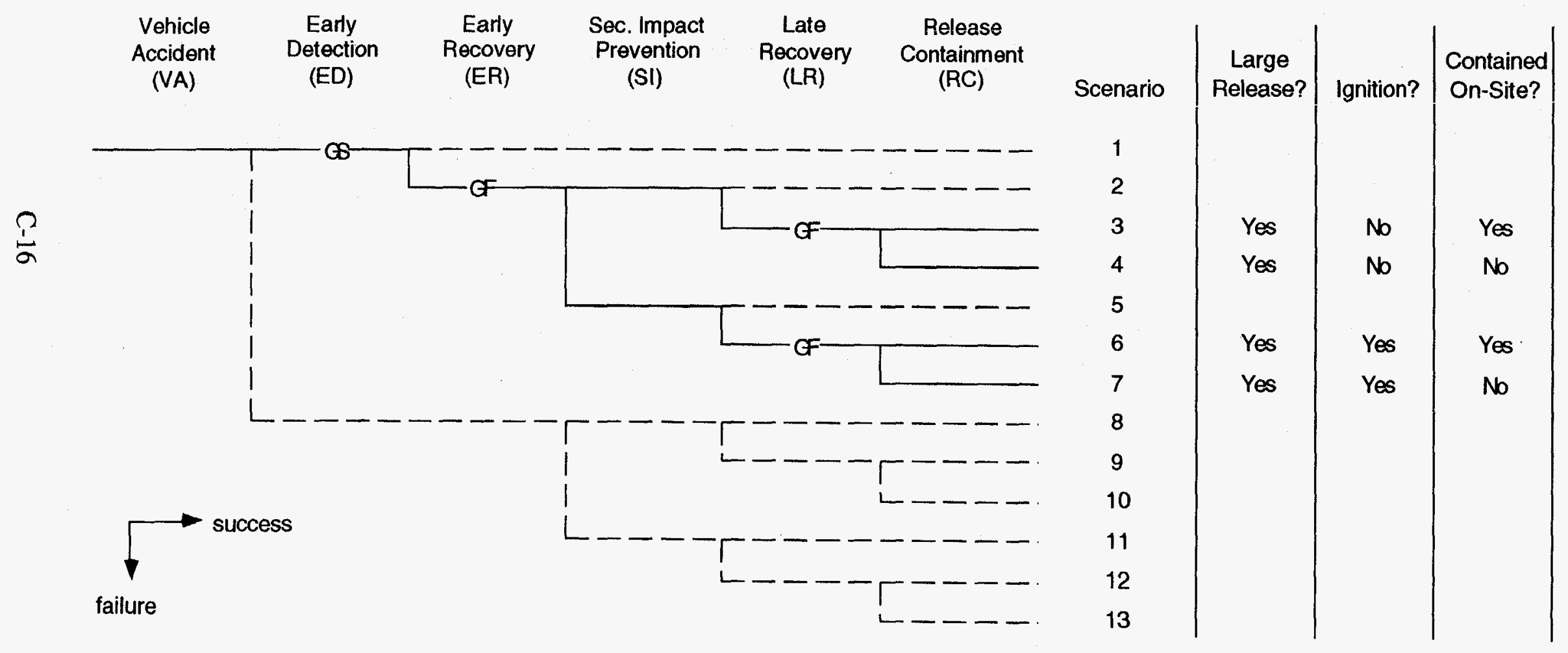




\section{Event Tree}

Valve Failure - Isolable

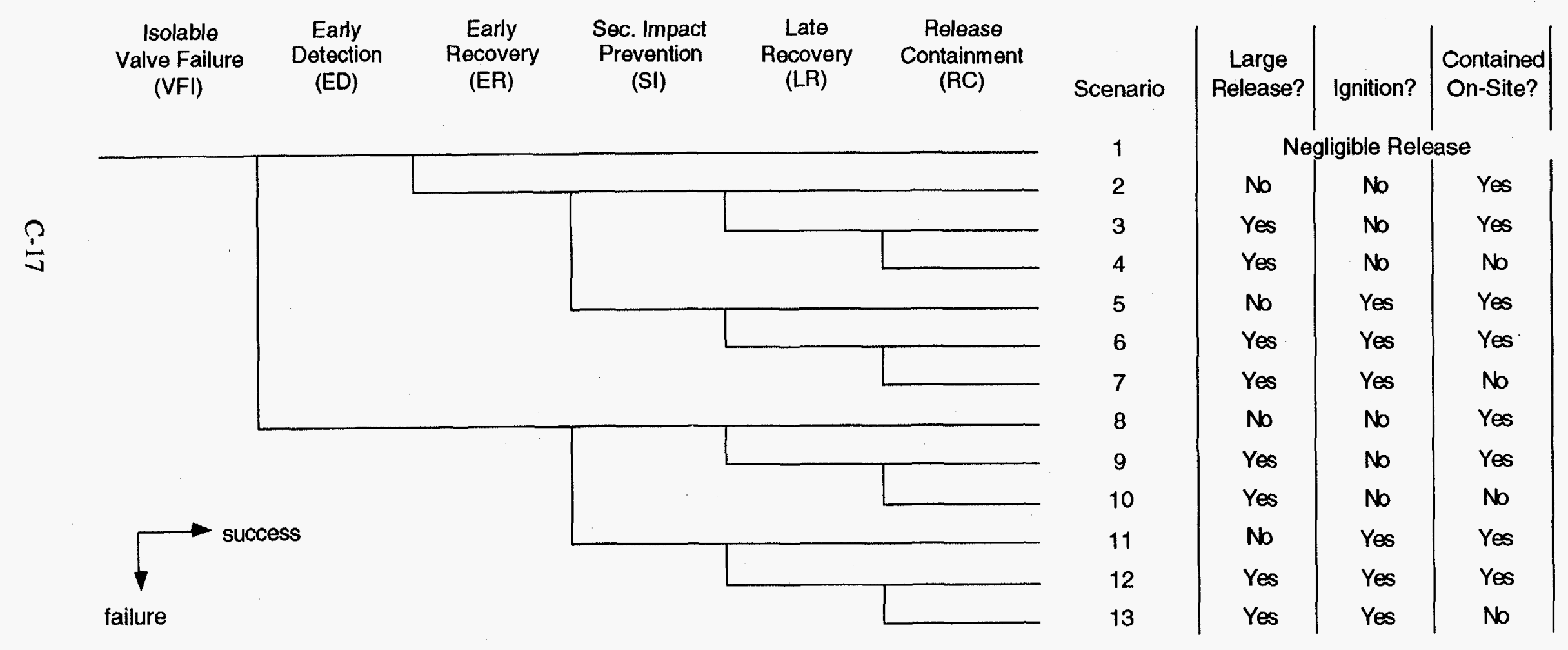




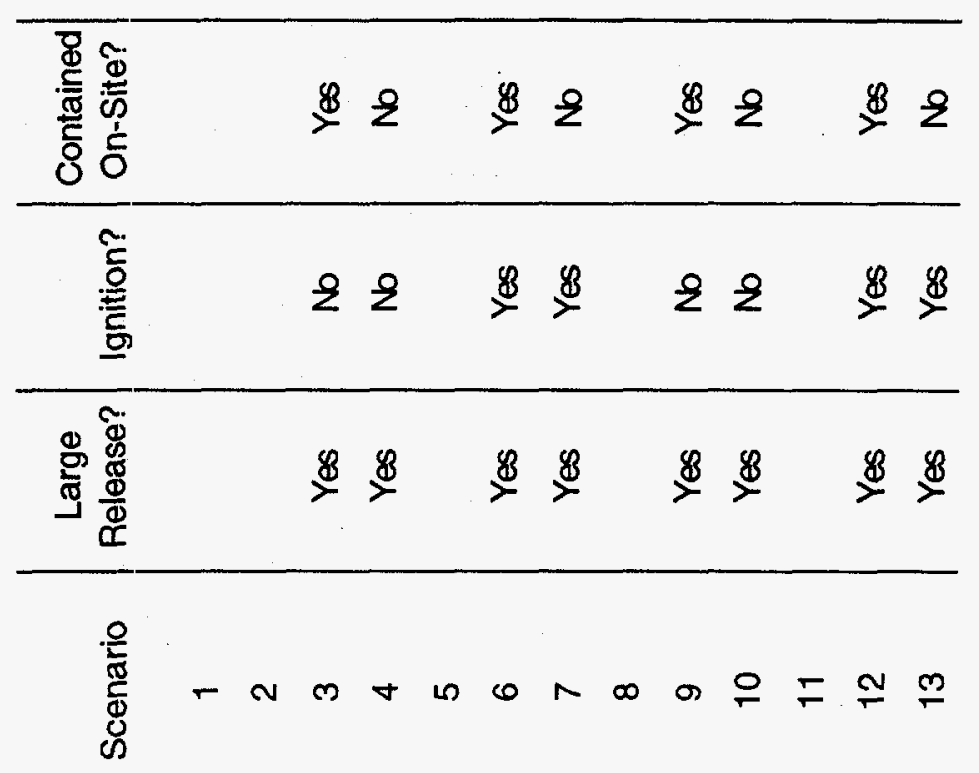

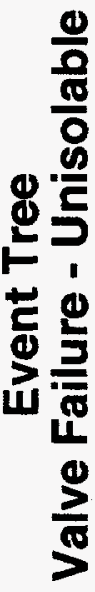

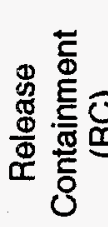

芯
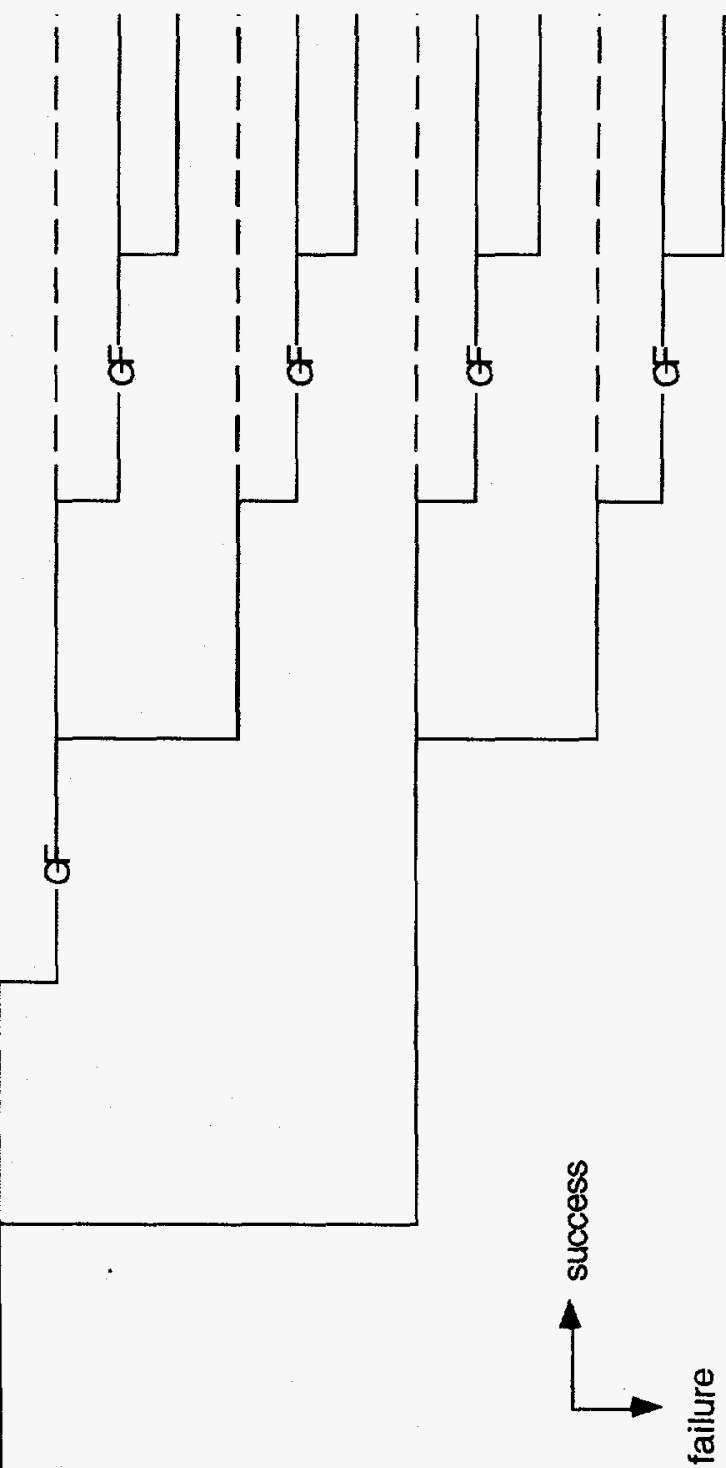

C-18 
Appendix D - Large Consequence Scenarios

Legend: $\quad \mathrm{IE} \quad=$ initiating event

$\mathrm{XX}$ = failure of top event "XX"

$\mathrm{XX}^{\prime}=$ guaranteed failure of top event " $\mathrm{XX}$ "

IXX = success of top event "XX"

$/ X^{\prime}=$ guaranteed success of top event "XX" 
Table D-1. Scenarios Leading to Large Releases

\begin{tabular}{|c|c|c|c|c|c|c|}
\hline IE & \multicolumn{5}{|c|}{ Top Events } & Notes \\
\hline$\overline{\mathrm{CAI}}$ & $\overline{/ \mathrm{ED}^{\prime}}$ & $\overline{\overline{E R}}$ & ISI & $\overline{L R}$ & $/ \mathrm{RC}$ & Dominant CAI \\
\hline CAI & $/ \mathrm{ED}^{\prime}$ & $\mathrm{ER}^{\prime}$ & $/ \mathrm{SI}$ & LR & $\mathrm{RC}$ & \\
\hline $\mathrm{CAI}$ & $/ \mathrm{ED}^{\prime}$ & $\mathrm{ER}^{\prime}$ & SI & LR & $/ \mathrm{RC}$ & \\
\hline CAI & $/ \mathrm{ED}^{\prime}$ & $\mathrm{ER}^{\prime}$ & SI & LR & $\mathrm{RC}$ & \\
\hline $\mathrm{CAU}$ & $/ \mathrm{ED}^{\prime}$ & $\mathrm{ER}^{\prime}$ & $/ \mathrm{SI}$ & LR' $^{\prime}$ & $/ \mathrm{RC}$ & Dominant CAU \\
\hline $\mathrm{CAU}$ & /ED' & $E^{\prime} R^{\prime}$ & /SI & LR' & $\mathrm{RC}$ & \\
\hline $\mathrm{CAU}$ & $/ \mathrm{ED}^{\prime}$ & $E^{\prime}$ & SI & LR' $^{\prime}$ & $/ \mathrm{RC}$ & \\
\hline CAU & $/ \mathrm{ED}^{\prime}$ & ER' & SI & $\mathbf{L R}^{\prime}$ & $\mathrm{RC}$ & \\
\hline $\mathrm{EE}$ & $\mathrm{ED}$ & ER' & ISI & LR' $^{\prime}$ & $/ \mathrm{RC}$ & \\
\hline$\overline{\mathrm{EE}}$ & $/ \mathrm{ED}$ & $\mathrm{ER}^{\prime}$ & /SI & $\mathrm{LR}^{\prime}$ & $\mathrm{RC}$ & \\
\hline $\mathrm{EE}$ & $\overline{\mathrm{ED}}$ & ER' & SI & $\mathrm{LR}^{\prime}$ & /RC & \\
\hline $\mathrm{EE}$ & /ED & ER' $^{\prime}$ & SI & $\mathrm{LR}^{\prime}$ & $\mathrm{RC}$ & \\
\hline $\mathrm{EE}$ & ED & $\mathrm{ER}^{\prime}$ & /SI & $\mathrm{LR}^{\prime}$ & $/ \mathrm{RC}$ & Dominant EE \\
\hline $\mathrm{EE}$ & $\mathrm{ED}$ & $\mathrm{ER}^{\prime}$ & /SI & $\mathrm{LR}^{\prime}$ & $\mathrm{RC}$ & \\
\hline $\mathrm{EE}$ & $\mathrm{ED}$ & $\mathrm{ER}^{\prime}$ & SI & $\mathrm{LR}^{\prime}$ & $/ \mathrm{RC}$ & \\
\hline $\mathrm{EE}$ & $\mathrm{ED}$ & $\mathrm{ER}^{\prime}$ & SI & $\mathrm{LR}^{\prime}$ & $\mathrm{RC}$ & \\
\hline $\mathrm{HF}$ & /ED & ER & ISI & LR & $/ \mathrm{RC}$ & Dominant $\mathrm{HF}$ \\
\hline $\mathrm{HF}$ & $/ \mathrm{ED}$ & ER & $/ \mathrm{SI}$ & LR & $\mathrm{RC}$ & \\
\hline $\mathrm{HF}$ & IED & ER & SI & LR & $/ \mathrm{RC}$ & \\
\hline $\mathrm{HF}$ & /ED & ER & SI & LR & $\mathrm{RC}$ & \\
\hline $\mathrm{HF}$ & ED & $E^{\prime}$ & ISI & LR & $/ \mathrm{RC}$ & \\
\hline $\mathrm{HF}$ & $\mathrm{ED}$ & $\mathrm{ER}^{\prime}$ & /SI & LR & $\mathrm{RC}$ & \\
\hline $\mathrm{HF}$ & $\mathrm{ED}$ & $\mathrm{ER}^{\prime}$ & SI & LR & $/ \mathrm{RC}$ & \\
\hline $\mathrm{HF}$ & ED & $\mathrm{ER}^{\prime}$ & SI & LR & $\mathrm{RC}$ & \\
\hline $\mathrm{OD}$ & /ED' & ER & ISI & LR & $/ \mathrm{RC}$ & Dominant OD \\
\hline OD & $/ \mathrm{ED}^{\prime}$ & ER & /SI & LR & $\mathrm{RC}$ & \\
\hline OD & /ED' & ER & SI & LR & /RC & \\
\hline OD & $/ \mathrm{ED}^{\prime}$ & ER & SI & LR & $\mathrm{RC}$ & \\
\hline $\mathrm{OF}$ & IED & ER & ISI & LR & $/ \mathrm{RC}$ & Dominant OF \\
\hline OF & $/ \mathrm{ED}$ & ER & $/ \mathrm{SI}$ & LR & RC & \\
\hline $\mathrm{OF}$ & /ED & ER & SI & LR & $/ \mathrm{RC}$ & \\
\hline $\mathrm{OF}$ & /ED & ER & SI & LR & $\mathrm{RC}$ & \\
\hline OF & ED & $\mathrm{ER}^{\prime}$ & /SI & LR & $/ \mathrm{RC}$ & \\
\hline $\mathrm{OF}$ & $\mathrm{ED}$ & $\mathrm{ER}^{\prime}$ & ISI & LR & $\mathrm{RC}$ & \\
\hline OF & $E D$ & $\mathrm{ER}^{\prime}$ & SI & LR & $/ \mathrm{RC}$ & \\
\hline $\mathrm{OF}$ & $\mathrm{ED}$ & ER' & SI & LR & $\mathrm{RC}$ & \\
\hline $\mathrm{OM}$ & IED & ER & ISI & LR & $/ \mathrm{RC}$ & Dominant OM \\
\hline OM & /ED & ER & ISI & LR & $\mathrm{RC}$ & \\
\hline $\mathrm{OM}$ & /ED & ER & SI & LR & /RC & \\
\hline OM & $/$ ED & ER & SI & LR & $\mathrm{RC}$ & \\
\hline OM & $E D$ & ER' $^{\prime}$ & ISI & LR & $/ \mathrm{RC}$ & Dominant OM \\
\hline $\mathrm{OM}$ & $\mathrm{ED}$ & ER' $^{\prime}$ & ISI & LR & $\mathrm{RC}$ & \\
\hline $\mathrm{OM}$ & ED & ER' $^{\prime}$ & SI & LR & /RC & \\
\hline OM & ED & ER $^{\prime}$ & SI & LR & $\mathrm{RC}$ & \\
\hline
\end{tabular}


Table D-1. Scenarios Leading to Large Releases (cont.)

\begin{tabular}{|c|c|c|c|c|c|c|}
\hline IE & \multicolumn{5}{|c|}{ Top Events } & Notes \\
\hline PFI & IED & ER & ISI & LR & /RC & Dominant PFI \\
\hline PFI & /ED & $\mathrm{ER}$ & ISI & LR & $\mathrm{RC}$ & \\
\hline PFI & IED & ER & SI & $\mathrm{LR}$ & /RC & \\
\hline PFI & IED & ER & SI & $\mathrm{LR}$ & $\mathrm{RC}$ & \\
\hline PFI & ED & $\mathrm{ER}^{\prime}$ & ISI & LR & IRC & Dominant PFI \\
\hline PFI & $\mathrm{ED}$ & $\mathrm{ER}^{\prime}$ & ISI & LR & $\mathrm{RC}$ & \\
\hline PFI & ED & $\mathrm{ER}^{\prime}$ & SI & LR & IRC & \\
\hline PFI & ED & $\mathrm{ER}^{\prime}$ & SI & LR & $\mathrm{RC}$ & \\
\hline $\mathrm{PFU}$ & /ED & ER' & ISI & $\mathrm{LR}^{\prime}$ & /RC & Dominant PFU \\
\hline PFU & /ED & $\mathrm{ER}^{\prime}$ & ISI & $\mathrm{LR}^{\prime}$ & $\mathrm{RC}$ & \\
\hline PFU & IED & $\mathrm{ER}^{\prime}$ & SI & $\mathrm{LR}^{\prime}$ & /RC & \\
\hline PFU & IED & $\mathrm{ER}^{\prime}$ & SI & $\mathrm{LR}^{\prime}$ & $\mathrm{RC}$ & \\
\hline PFU & ED & $\mathrm{ER}^{\prime}$ & ISI & $\mathrm{LR}^{\prime}$ & /RC & \\
\hline $\mathrm{PFU}$ & $\mathrm{ED}$ & $\mathrm{ER}^{\prime}$ & ISI & $\mathbf{L R}^{\prime}$ & $\mathrm{RC}$ & \\
\hline PFU & $E D$ & $\mathrm{ER}^{\prime}$ & SI & $\mathrm{LR}^{\prime}$ & IRC & \\
\hline PFU & $\mathrm{ED}$ & $\mathrm{ER}^{\prime}$ & SI & $\mathrm{LR}^{\prime}$ & $\mathrm{RC}$ & \\
\hline SFI & IED & ER & ISI & LR & IRC & Dominant SFI \\
\hline SFI & /ED & ER & ISI & $\mathrm{LR}$ & $\mathrm{RC}$ & \\
\hline SFI & IED & ER & SI & LR & /RC & \\
\hline SFI & IED & ER & SI & $\mathrm{LR}$ & $\mathrm{RC}$ & \\
\hline SFI & ED & ER' & ISI & LR & IRC & Dominant SFI \\
\hline SFI & ED & $\mathrm{ER}^{\prime}$ & ISI & LR & $\mathrm{RC}$ & \\
\hline SFI & ED & $\mathrm{ER}^{\prime}$ & SI & LR & IRC & \\
\hline SFI & $E D$ & $E^{\prime}$ & SI & LR & $\mathrm{RC}$ & \\
\hline SFU & IED & $\mathrm{ER}^{\prime}$ & ISI & $\mathrm{LR}^{\prime}$ & /RC & Dominant SFU \\
\hline SFU & IED & $\mathrm{ER}^{\prime}$ & ISI & $\mathrm{LR}^{\prime}$ & $\mathrm{RC}$ & \\
\hline SFU & IED & $\mathrm{ER}^{\prime}$ & SI & $\mathrm{LR}^{\prime}$ & /RC & \\
\hline SFU & IED & $E^{\prime}$ & SI & $L^{\prime}$ & $\mathrm{RC}$ & \\
\hline SFU & ED & $\mathrm{ER}^{\prime}$ & ISI & $\mathrm{LR}^{\prime}$ & /RC & \\
\hline SFU & $E D$ & ER' & ISI & $\mathrm{LR}^{\prime}$ & $\mathrm{RC}$ & \\
\hline SFU & ED & $\mathrm{ER}^{\prime}$ & SI & $\mathrm{LR}^{\prime}$ & IRC & \\
\hline SFU & $E D$ & $E^{\prime}$ & SI & $\mathrm{LR}^{\prime}$ & $\mathrm{RC}$ & \\
\hline ST & IED & $\mathrm{ER}^{\prime}$ & ISI & $\mathrm{LR}^{\prime}$ & /RC & Dominant $\mathrm{ST}$ \\
\hline ST & IED & $\mathrm{ER}^{\prime}$ & ISI & $\mathrm{LR}^{\prime}$ & $\mathrm{RC}$ & \\
\hline ST & IED & $E^{\prime}$ & SI & $L^{\prime}$ & /RC & \\
\hline ST & IED & $\mathrm{ER}^{\prime}$ & SI & $L^{\prime}$ & $\mathrm{RC}$ & \\
\hline ST & ED & $\mathrm{ER}^{\prime}$ & ISI & $L^{\prime}$ & /RC & \\
\hline ST & ED & ER' & ISI & $L R^{\prime}$ & $\mathrm{RC}$ & \\
\hline ST & ED & ER' & SI & $L^{\prime}$ & /RC & \\
\hline$S T$ & ED & $\mathrm{ER}^{\prime}$ & SI & LR' $^{\prime}$ & $\mathrm{RC}$ & \\
\hline TTF & /ED & ER' & ISI & $\mathrm{LR}^{\prime}$ & /RC' & Dominant TTF \\
\hline TTF & IED & ER' & SI & \begin{tabular}{|l}
$R^{\prime}$ \\
\end{tabular} & $/ \mathrm{RC}^{\prime}$ & \\
\hline TTF & ED & $E^{\prime}$ & ISI & LR' $^{\prime}$ & /RC' & \\
\hline TTF & ED & ER' & SI & $\mathrm{LR}^{\prime}$ & $/ \mathrm{RC}^{\prime}$ & \\
\hline
\end{tabular}


Table D-1. Scenarios Leading to Large Releases (cont.)

\begin{tabular}{|c|c|c|c|c|c|c|}
\hline IE & \multicolumn{5}{|c|}{ Top Events } & Notes \\
\hline TTT & TED & $E^{E R^{\prime}}$ & ISI & $\overline{L R}^{\prime}$ & /RC & Dominant TTT \\
\hline TTT & /ED & $\mathrm{ER}^{\prime}$ & /SI & $\mathrm{LR}^{\prime}$ & $\mathrm{RC}$ & \\
\hline TTT & /ED & $\mathrm{ER}^{\prime}$ & SI & $\mathrm{LR}^{\prime}$ & IRC & \\
\hline TTT & /ED & $\mathrm{ER}^{\prime}$ & SI & LR' & $\mathrm{RC}$ & \\
\hline TTT & $\mathrm{ED}$ & $\mathrm{ER}^{\prime}$ & ISI & $\mathrm{LR}^{\prime}$ & /RC & \\
\hline TTT & $\mathrm{ED}$ & $\mathrm{ER}^{\prime}$ & /SI & $\mathrm{LR}^{\prime}$ & $\mathrm{RC}$ & \\
\hline TTT & $\mathrm{ED}$ & $E R^{\prime}$ & SI & $\mathrm{LR}^{\prime}$ & /RC & \\
\hline TTT & $\mathrm{ED}$ & $E^{\prime}$ & SI & $\mathrm{LR}^{\prime}$ & $\mathrm{RC}$ & \\
\hline VA & $/ \mathrm{ED}^{\prime}$ & $\mathrm{ER}^{\prime}$ & /SI & $\mathrm{LR}^{\prime}$ & /RC & Dominant VA \\
\hline VA & IED' & $\mathrm{ER}^{\prime}$ & ISI & $\mathrm{LR}^{\prime}$ & $\mathrm{RC}$ & \\
\hline VA & IED' & ER' & SI & $\mathrm{LR}^{\prime}$ & /RC & \\
\hline VA & IED' & $\mathrm{ER}^{\prime}$ & SI & $L^{\prime} R^{\prime}$ & $\mathrm{RC}$ & \\
\hline $\mathrm{VFI}$ & IED & ER & ISI & LR & /RC & Dominant VFI \\
\hline VFI & $/ \mathrm{ED}$ & ER & ISI & LR & $\mathrm{RC}$ & \\
\hline VFI & $/ \mathrm{ED}$ & ER & SI & LR & /RC & \\
\hline VFI & IED & ER & SI & LR & $\mathrm{RC}$ & \\
\hline VFI & ED & $\mathrm{ER}^{\prime}$ & ISI & LR & /RC & Dominant VFI \\
\hline VFI & ED & $\mathrm{ER}^{\prime}$ & ISI & LR & $\mathrm{RC}$ & \\
\hline VFI & ED & $\mathrm{ER}^{\prime}$ & SI & LR & /RC & \\
\hline VFI & ED & $\mathrm{ER}^{\prime}$ & SI & LR & $\mathrm{RC}$ & \\
\hline VFU & IED & $\mathrm{ER}^{\prime}$ & ISI & $\mathrm{LR}^{\prime}$ & IRC & Dominant VFU \\
\hline VFU & IED & $\mathrm{ER}^{\prime}$ & ISI & LR' & $\mathrm{RC}$ & \\
\hline VFU & FED & $\mathrm{ER}^{\prime}$ & $\mathrm{SI}$ & LR' & /RC & \\
\hline VFU & /ED & $\mathrm{ER}^{\prime}$ & SI & LR' & $\mathrm{RC}$ & \\
\hline VFU & ED & $\mathbf{E R}^{\prime}$ & ISI & LR' $^{\prime}$ & /RC & \\
\hline VFU & ED & $\mathrm{ER}^{\prime}$ & ISI & LR' & $\mathrm{RC}$ & \\
\hline VFU & $\mathrm{ED}$ & $\mathrm{ER}^{\prime}$ & SI & LR' & IRC & \\
\hline VFU & ED & $\mathrm{ER}^{\prime}$ & SI & LR' $^{\prime}$ & $\mathrm{RC}$ & \\
\hline
\end{tabular}


Table D-2. Scenarios Leading to Large Releases with Onsite Ignition

\begin{tabular}{|c|c|c|c|c|c|c|}
\hline IE & \multicolumn{5}{|c|}{ Top Events } & Notes \\
\hline $\mathrm{CAI}$ & $/ \mathrm{ED}^{\prime}$ & $\mathrm{ER}^{\prime}$ & SI & LR & IRC & Dominant CAI \\
\hline CAI & $/ \mathrm{ED}^{\prime}$ & $\mathrm{ER}^{\prime}$ & SI & LR & $\mathrm{RC}$ & \\
\hline $\mathrm{CAU}$ & /ED' & ER' $^{\prime}$ & SI & $\mathbf{L R}^{\prime}$ & /RC & Dominant CAU \\
\hline $\mathrm{CAU}$ & $/ \mathrm{ED}^{\prime}$ & ER' & SI & $\mathbf{L R}^{\prime}$ & $\mathrm{RC}$ & \\
\hline $\mathrm{EE}$ & EDD & $\mathrm{ER}^{\prime}$ & SI & $\mathbf{L R}^{\prime}$ & /RC & \\
\hline $\mathrm{EE}$ & IED & $\mathrm{ER}^{\prime}$ & SI & $\mathbf{L R}^{\prime}$ & $\mathrm{RC}$ & \\
\hline $\mathrm{EE}$ & $\mathrm{ED}$ & $\mathrm{ER}^{\prime}$ & SI & $\mathbf{L R}^{\prime}$ & IRC & Dominant EE \\
\hline $\mathrm{EE}$ & $\mathrm{ED}$ & $\mathrm{ER}^{\prime}$ & SI & $\mathrm{LR}^{\prime}$ & $\mathrm{RC}$ & \\
\hline $\mathrm{HF}$ & $/ \mathrm{ED}$ & ER & SI & LR & /RC & Dominant HF \\
\hline $\mathrm{HF}$ & /ED & ER & SI & LR & $\mathrm{RC}$ & \\
\hline $\mathrm{HF}$ & $\mathrm{ED}$ & ER $^{\prime}$ & SI & LR & /RC & \\
\hline $\mathrm{HF}$ & ED & $\mathrm{ER}^{\prime}$ & SI & LR & $\mathrm{RC}$ & \\
\hline $\mathrm{OD}$ & $/ \mathrm{ED}^{\prime}$ & ER & $S I$ & LR & /RC & Dominant OD \\
\hline OD & /ED' & ER & SI & $\mathrm{LR}$ & $\mathrm{RC}$ & \\
\hline $\mathrm{OF}$ & $/ \mathrm{ED}$ & ER & SI & LR & /RC & Dominant OF \\
\hline $\mathrm{OF}$ & $/ E D$ & ER & $S I$ & LR & $\mathrm{RC}$ & \\
\hline $\mathrm{OF}$ & $\mathrm{ED}$ & ER' & SI & LR & /RC & \\
\hline $\mathrm{OF}$ & $\mathrm{ED}$ & $\mathrm{ER}^{\prime}$ & SI & LR & $\mathrm{RC}$ & \\
\hline $\mathrm{OM}$ & /ED & ER & SI & LR & IRC & Dominant OM \\
\hline $\mathrm{OM}$ & /ED & ER & SI & LR & $\mathrm{RC}$ & \\
\hline $\mathrm{OM}$ & ED & $\mathrm{ER}^{\prime}$ & SI & LR & IRC & Dominant OM \\
\hline $\mathrm{OM}$ & $\mathrm{ED}$ & $\mathrm{ER}^{\prime}$ & SI & LR & $\mathrm{RC}$ & \\
\hline PFI & /ED & ER & SI & LR & /RC & Dominant PFI \\
\hline PFI & /ED & ER & SI & LR & $\mathrm{RC}$ & \\
\hline PFI & $\mathrm{ED}$ & $\mathrm{ER}^{1}$ & SI & LR & IRC & Dominant PFI \\
\hline PFI & $\mathrm{ED}$ & $\mathrm{ER}^{\prime}$ & SI & LR & $\mathrm{RC}$ & \\
\hline $\mathrm{PFU}$ & /ED & $\mathrm{ER}^{\prime}$ & SI & LR' $^{\prime}$ & /RC & Dominant PFU \\
\hline PFU & IED & $\mathrm{ER}^{\prime}$ & SI & LR' & $\mathrm{RC}$ & \\
\hline PFU & ED & ER' & SI & $\mathrm{LR}^{\prime}$ & IRC & \\
\hline $\mathrm{PFU}$ & $\mathrm{ED}$ & $\mathrm{ER}^{\prime}$ & SI & $\mathbf{L R}^{\prime}$ & $\mathrm{RC}$ & \\
\hline SFI & /ED & ER & SI & LR & /RC & Dominant SFI \\
\hline SFI & IED & ER & SI & LR & $\mathrm{RC}$ & \\
\hline SFI & ED & $\mathrm{ER}^{\prime}$ & SI & LR & /RC & Dominant SFI \\
\hline SFI & $\mathrm{ED}$ & ER' & SI & LR & $\mathrm{RC}$ & \\
\hline SFU & $/ \mathrm{ED}$ & $\mathrm{ER}^{\prime}$ & SI & LR' $^{\prime}$ & /RC & Dominant SFU \\
\hline SFU & /ED & $\mathrm{ER}^{\prime}$ & SI & $\mathbf{L R}^{\prime}$ & $\mathrm{RC}$ & \\
\hline SFU & $\mathrm{ED}$ & ER' & SI & $\mathbf{L R}^{\prime}$ & IRC & \\
\hline SFU & $\mathrm{ED}$ & ER' & SI & $\overline{\text { LR' }^{\prime}}$ & $\mathrm{RC}$ & \\
\hline ST & IED & $\mathrm{ER}^{\prime}$ & SI & $\mathbf{L R}^{\prime}$ & /RC & Dominant ST \\
\hline ST & /ED & $\mathrm{ER}^{\prime}$ & SI & LR' $^{\prime}$ & $\mathrm{RC}$ & \\
\hline ST & $\mathrm{ED}$ & $\mathrm{ER}^{\prime}$ & SI & $\mathbf{L R}^{\prime}$ & IRC & \\
\hline ST & $\mathrm{ED}$ & $\mathrm{ER}^{\prime}$ & SI & $\overline{\text { LR' }^{\prime}}$ & $\mathrm{RC}$ & \\
\hline TTF & EED & $\mathrm{ER}^{\prime}$ & SI & $\mathrm{LR}^{\prime}$ & /RC' & Dominant TIF \\
\hline TTF & $\mathrm{ED}$ & $\mathrm{ER}^{\prime}$ & SI & LR' $^{\prime}$ & /RC' & \\
\hline
\end{tabular}


Table D-2. Scenarios Leading to Large Releases with Onsite Ignition (cont.)

\begin{tabular}{|c|c|c|c|c|c|c|}
\hline $\mathbf{I E}^{\infty}$ & \multicolumn{5}{|c|}{ Top Events } & Notes \\
\hline$\overline{\text { TTT }}$ & $\overline{\text { /ED }}$ & $\mathrm{ER}^{\prime}$ & SI & $\mathrm{LR}^{\prime}$ & $/ \mathrm{RC}$ & Dominant TTT \\
\hline TTT & /ED & $\mathrm{ER}^{\prime}$ & SI & $\overline{L^{\prime}}$ & $\mathrm{RC}$ & \\
\hline TTT & $\mathrm{ED}$ & $\mathrm{ER}^{\prime}$ & SI & $\mathrm{LR}^{\prime}$ & /RC & \\
\hline TTT & $\mathrm{ED}$ & $\mathrm{ER}^{\prime}$ & SI & LR' $^{\prime}$ & $\mathrm{RC}$ & \\
\hline VA & IED' & $\mathrm{ER}^{\prime}$ & SI & $\mathrm{LR}^{\prime}$ & /RC & Dominant VA \\
\hline VA & /ED & $\mathrm{ER}^{\prime}$ & SI & $\mathrm{LR}^{\prime}$ & $\mathrm{RC}$ & \\
\hline VFI & /ED & ER & SI & LR & /RC & Dominant VFI \\
\hline VFI & $\mathrm{EDD}$ & ER & SI & LR & $\mathrm{RC}$ & \\
\hline VFI & $\mathrm{ED}$ & ER' & SI & LR & /RC & Dominant VFI \\
\hline VFI & $\mathrm{ED}$ & $\mathrm{ER}^{\prime}$ & SI & LR & $\mathrm{RC}$ & \\
\hline VFU & /ED & $\mathrm{ER}^{\prime}$ & SI & $\mathrm{LR}^{\prime}$ & /RC & Dominant VFU \\
\hline VFU & EED & $\mathrm{ER}^{\prime}$ & SI & $\mathrm{LR}^{\prime}$ & $\mathrm{RC}$ & \\
\hline VFU & ED & $\mathrm{ER}^{\prime}$ & SI & $\mathrm{LR}^{\prime}$ & IRC & \\
\hline VFU & ED & $\mathrm{ER}^{\prime}$ & SI & $\mathrm{LR}^{\prime}$ & $\mathrm{RC}$ & \\
\hline
\end{tabular}


Table D-3. Scenarios Leading to Large Offsite Releases

\begin{tabular}{|c|c|c|c|c|c|c|}
\hline IE & \multicolumn{5}{|c|}{ Top Events } & Notes \\
\hline $\mathrm{CAI}$ & /ED' & $\mathrm{ER}^{\prime}$ & /SI & LR & $\mathrm{RC}$ & Dominant $\mathrm{CAI}$ \\
\hline $\mathrm{CAI}$ & /ED' & $\mathrm{ER}^{\prime}$ & SI & LR & $\mathrm{RC}$ & \\
\hline $\mathrm{CAU}$ & $/ \mathrm{ED}^{\prime}$ & $\mathrm{ER}^{\prime}$ & $/ \mathrm{SI}$ & LR' $^{\prime}$ & $\mathrm{RC}$ & Dominant CAU \\
\hline $\mathrm{CAU}$ & $/ \mathrm{ED}^{\prime}$ & $\mathrm{ER}^{\prime}$ & SI & $\mathbf{L R}^{\prime}$ & $\mathrm{RC}$ & \\
\hline $\mathrm{EE}$ & ED & ER' & SSI & $\mathrm{LR}^{\prime}$ & $\mathrm{RC}$ & \\
\hline $\mathrm{EE}$ & IED & $\mathrm{ER}^{\prime}$ & SI & $\mathrm{LR}^{\prime}$ & $\mathrm{RC}$ & \\
\hline $\mathrm{EE}$ & ED & $\mathrm{ER}^{\prime}$ & $/ S I$ & $\mathrm{LR}^{\prime}$ & $\mathrm{RC}$ & Dominant EE \\
\hline $\mathrm{EE}$ & ED & $\mathrm{ER}^{\prime}$ & SI & $\mathbf{L R}^{\prime}$ & $\mathrm{RC}$ & \\
\hline $\mathrm{HF}$ & EDD & ER & ISI & LR & $\mathrm{RC}$ & Dominant HF \\
\hline $\mathrm{HF}$ & IED & ER & SI & LR & $\mathrm{RC}$ & \\
\hline $\mathrm{HF}$ & $\mathrm{ED}$ & $\mathrm{ER}^{\prime}$ & /SI & LR & $\mathrm{RC}$ & \\
\hline $\mathrm{HF}$ & $\mathrm{ED}$ & $\mathrm{ER}^{\prime}$ & SI & LR & $\mathrm{RC}$ & \\
\hline OD & /ED' & ER & ISI & LR & $\mathrm{RC}$ & Dominant OD \\
\hline OD & /ED' & ER & SI & $\mathrm{LR}$ & RC & \\
\hline $\mathrm{OF}$ & /ED & ER & ISI & LR & $\mathrm{RC}$ & Dominant OF \\
\hline OF & /ED & ER & SI & LR & $\mathrm{RC}$ & \\
\hline $\mathrm{OF}$ & ED & $\mathrm{ER}^{\prime}$ & $/ S I$ & LR & $\mathrm{RC}$ & \\
\hline $\mathrm{OF}$ & $\mathrm{ED}$ & ER' & $\mathrm{SI}$ & LR & $\mathrm{RC}$ & \\
\hline $\mathrm{OM}$ & /ED & ER & ISI & LR & $\mathrm{RC}$ & Dominant OM \\
\hline $\mathrm{OM}$ & $/ \mathrm{ED}$ & ER & SI & LR & RC & \\
\hline $\mathrm{OM}$ & $\mathrm{ED}$ & $\mathrm{ER}^{\prime}$ & ISI & $\mathrm{LR}$ & $\mathrm{RC}$ & Dominant $\mathrm{OM}$ \\
\hline $\mathrm{OM}$ & ED & $\mathrm{ER}^{\prime}$ & SI & LR & RC & \\
\hline PFI & IED & ER & ISI & LR & RC & Dominant PFI \\
\hline PFI & /ED & ER & SI & LR & RC & \\
\hline PFI & $\mathrm{ED}$ & $\mathrm{ER}^{\prime}$ & /SI & LR & $\mathrm{RC}$ & Dominant PFI \\
\hline PFI & $\mathrm{ED}$ & $\mathrm{ER}^{\prime}$ & SI & LR & $\mathrm{RC}$ & \\
\hline PFU & /ED & $E R^{\prime}$ & $I S I$ & $\mathrm{LR}^{\prime}$ & $\mathrm{RC}$ & Dominant PFU \\
\hline PFU & /ED & ER' $^{\prime}$ & SI & $\mathrm{LR}^{\prime}$ & $\mathrm{RC}$ & \\
\hline PFU & $\mathrm{ED}$ & $\mathrm{ER}^{\prime}$ & ISI & $\mathrm{LR}^{\prime}$ & $\mathrm{RC}$ & \\
\hline PFU & $\mathrm{ED}$ & $\mathrm{ER}^{\prime}$ & SI & $\mathrm{LR}^{\prime}$ & RC & \\
\hline SFI & IED & ER & ISI & $\mathrm{LR}$ & $\mathbf{R C}$ & Dominant SFI \\
\hline $\mathrm{SFI}$ & $\mathrm{ED}$ & $E R$ & SI & $\mathrm{LR}$ & $\mathrm{RC}$ & \\
\hline SFI & $\mathrm{ED}$ & $\mathrm{ER}^{\prime}$ & /SI & $\mathrm{LR}$ & $\mathrm{RC}$ & Dominant SFI \\
\hline SFI & $\mathrm{ED}$ & $\mathrm{ER}^{\prime}$ & SI & LR & $\mathrm{RC}$ & \\
\hline SFU & $/ \mathrm{ED}$ & $\mathrm{ER}^{\prime}$ & ISI & $\mathrm{LR}^{\prime}$ & $\mathrm{RC}$ & Dominant SFU \\
\hline SFU & $\mathrm{ED}$ & $\mathrm{ER}^{\prime}$ & SI & $\mathrm{LR}^{\prime}$ & $\mathrm{RC}$ & \\
\hline SFU & $\mathrm{ED}$ & $\mathrm{ER}^{\prime}$ & ISI & $\mathrm{LR}^{\prime}$ & $\mathrm{RC}$ & \\
\hline SFU & ED & ER' & SI & $\mathrm{LR}^{\prime}$ & $\mathrm{RC}$ & \\
\hline ST & IED & ER' $^{\prime}$ & SSI & $\mathrm{LR}^{\prime}$ & $\mathrm{RC}$ & Dominant ST \\
\hline ST & $/ \mathrm{ED}$ & ER' $^{\prime}$ & $\mathrm{SI}$ & $\mathrm{LR}^{\prime}$ & $\mathrm{RC}$ & \\
\hline ST & $\mathrm{ED}$ & $\mathrm{ER}^{\prime}$ & ISI & $\mathrm{LR}^{\prime}$ & $\mathrm{RC}$ & \\
\hline ST & $\mathrm{ED}$ & ER' & SI & LR' $^{\prime}$ & $\mathrm{RC}$ & \\
\hline TTT & /ED & ER' $^{\prime}$ & ISI & $\mathrm{LR}^{\prime}$ & $\mathrm{RC}$ & Dominant TTT \\
\hline TTT & $\mathrm{ED}$ & $\mathrm{ER}^{\prime}$ & SI & $\mathrm{LR}^{\prime}$ & $\mathrm{RC}$ & \\
\hline TTT & $\mathrm{ED}$ & $\mathrm{ER}^{\prime}$ & ISI & LR' $^{\prime}$ & $\mathrm{RC}$ & \\
\hline TTT & $\mathrm{ED}$ & ER' & $\mathrm{SI}$ & LR' $^{\prime}$ & $\mathrm{RC}$ & \\
\hline
\end{tabular}


Table D-3. Scenarios Leading to Large Offsite Releases (cont.)

\begin{tabular}{|c|c|c|c|c|c|c|}
\hline IE & \multicolumn{5}{|c|}{ Top Events } & Notes \\
\hline VA & $/ \mathrm{ED}^{\prime}$ & $\mathrm{ER}^{\prime}$ & $/ \mathrm{SI}$ & $\mathrm{LR}^{\prime}$ & $\mathrm{RC}$ & Dominant VA \\
\hline VA & $/ \mathrm{ED}^{\prime}$ & ER' $^{\prime}$ & SI & LR' & $\mathrm{RC}$ & \\
\hline VFI & $/ \mathrm{ED}$ & ER & $/ \mathrm{SI}$ & LR & $\mathrm{RC}$ & Dominant VFI \\
\hline VFI & $/ \mathrm{ED}$ & ER & SI & LR & $\mathrm{RC}$ & \\
\hline VFI & $\mathrm{ED}$ & ER' & /SI & LR & $\mathrm{RC}$ & Dominant VFI \\
\hline VFI & $\mathrm{ED}$ & ER' & SI & LR & $\mathrm{RC}$ & \\
\hline VFU & $/ \mathrm{ED}$ & $\mathrm{ER}^{\prime}$ & /SI & LR' & $\mathrm{RC}$ & Dominant VFU \\
\hline VFU & /ED & $\mathrm{ER}^{\prime}$ & SI & $\mathrm{LR}^{\prime}$ & $\mathrm{RC}$ & \\
\hline VFU & $\mathrm{ED}$ & $\mathrm{ER}^{\prime}$ & /SI & $\mathrm{LR}^{\prime}$ & $\mathrm{RC}$ & \\
\hline VFU & ED & $\mathrm{ER}^{\prime}$ & SI & LR $^{\prime}$ & $\mathrm{RC}$ & \\
\hline
\end{tabular}

